\title{
Socijalno-semiotički pristup analizi srpskih bukvara od 1965. do 2011.
}

\section{Puškar, Nataša}

Doctoral thesis / Disertacija

2020

Degree Grantor / Ustanova koja je dodijelila akademski / stručni stupanj: University of Zagreb, University of Zagreb, Faculty of Humanities and Social Sciences / Sveučilište u Zagrebu, Filozofski fakultet

https://doi.org/10.17234/diss.2020.7706

Permanent link / Trajna poveznica: https://urn.nsk.hr/urn:nbn:hr:131:170326

Rights / Prava: In copyright/Zaštićeno autorskim pravom.

Download date / Datum preuzimanja: 2023-04-26

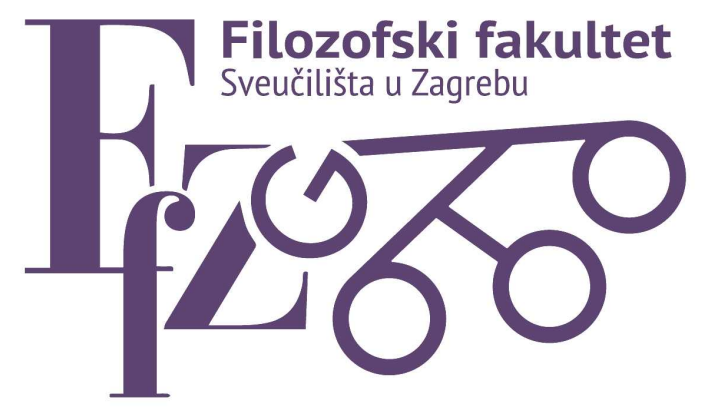

Repository / Repozitorij:

ODRAZ - open repository of the University of Zagreb Faculty of Humanities and Social Sciences
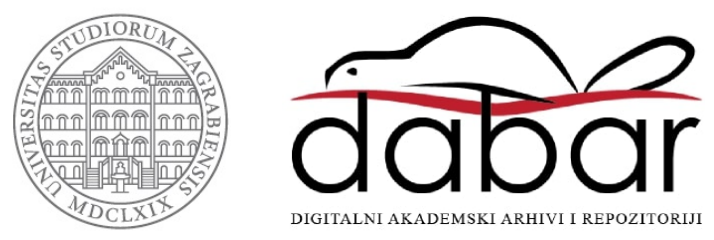
Filozofski fakultet

Nataša Puškar

\section{SOCIJALNO-SEMIOTIČKI PRISTUP ANALIZI SRPSKIH BUKVARA OD 1965. DO 2011.}

DOKTORSKI RAD

Zagreb, 2020. 


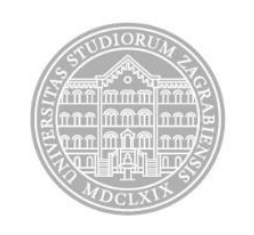

Sveučilište u Zagrebu

Filozofski fakultet

Nataša Puškar

\title{
SOCIJALNO-SEMIOTIČKI PRISTUP ANALIZI SRPSKIH BUKVARA OD 1965. DO 2011.
}

DOKTORSKI RAD

\author{
Mentori: \\ Dr.sc. Milorad Pupovac \\ Dr. sc. Mislava Bertoša
}

Zagreb, 2020. 


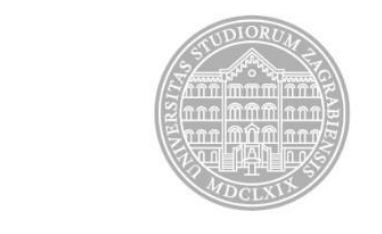

University of Zagreb

Faculty of Humanities and Social Studies

Nataša Puškar

\title{
SOCIAL SEMIOTIC ANALYSIS OF SERBIAN ABC BOOKS FROM 1965 TO 2011
}

\author{
DOCTORAL THESIS
}

Supervisors:

Milorad Pupovac

Mislava Bertoša

Zagreb, 2020. 


\section{O MENTORIMA}

\section{Milorad Pupovac}

Na Filozofskom fakultetu Sveučilišta u Zagrebu studirao je filozofiju i lingvistiku, te 1979. godine diplomirao na obje studijske grupe. 1982. zapošljava se na Odsjeku za lingvistiku i orijentalne studije na sociolingvističkom istraživačkom projektu koji je sam pripremio i koji je radio pod vodstvom Dubravka Škiljana „Društveno raslojavanje jezika“. Postiplomski studij završava 1983. godine na Odsjeku za filozofiju Filozofskog fakulteta Sveučilišta u Ljubljani, gdje brani magistarski rad „Lingvistika i ideologija“. Doktorsku disertaciju „Jezik i djelovanje“ obranio je 1986. godine. Iste godine izabran je u zvanje docenta, a četiri godine kasnije u zvanje izvanrednog profesora, kada postaje predstojnik Katedre za primijenjenu lingvistiku. U tom razdoblju najveći dio njegova interesa posvećen je sociolingvistici, pragmalingvistici, filozofiji jezika i epistemologiji lingvistike. Tokom 90-tih njegov se interes proširuje na javnu komunikaciju i analizu diskursa, psiholingvistiku (posebno problem učenja jezika i jezičnih poremećaja), te produbljuje njegov interes za epistemologiju lingvistike. Početkom 2000-tih u područje njegova interesa ulazi problematika semantika razumijevanja i etika govorenja. Na osnovi tih interesa u vrijeme reforme ukupnog studija oblikuje studije primijenjene lingvistike. U drugoj polovici 90-tih i početkom 2000-tih bio je predavač na Institutu za humanističke studije u Ljubljani, predajući teme iz sociolingvistike. 1996. stipendist je Centra Woodrow Wilson (Washington, DC) za međunarodne znanstvenike. 1998/1999. godine bio je stipendist Fulbrightova programa na Sveučilištu Cornell (Ithaca, NY). Autor je nekoliko knjiga s područja lingvistike: Lingvistika i ideologija, Jezik i djelovanje, Politička komunikacija. Urednik je ili koeditor Jezici i politike te Marksizam i lingvistika. Autor je preko stotine znanstvenih i stručnih radova. Osim lingvističkih radova i predavanja, obavljivao je radove i držao predavanja s područja međuetničkih odnosa, manjinskih pitanja i političkih odnosa u regiji jugoistočne Evrope.

\section{Mislava Bertoša}

Na Filozofskom fakultetu Sveučilišta u Zagrebu diplomirala je filozofiju i opću lingvistiku. Magistrirala je 2002. godine na Sveučilištu u Zadru, a doktorirala na Filozofskom fakultetu Sveučilišta u Zagrebu 2007. godine. Od 2000. godine zaposlena je na Odsjeku za lingvistiku 
Filozofskog fakulteta Sveučilišta u Zagrebu, trenutačno kao izvanredni profesor i predstojnica Katedre za semiologiju. Bavi se temama s područja onomastike, sociosemiotike i semiologije, analiza diskursa, odnosa jezika i identiteta te jezika i roda. Sudjelovala je na nekoliko domaćih i međunarodnih znanstvenih projekata te na dvadesetak znanstvenih skupova. Predaje na Poslijediplomskom doktorskom studiju lingvistike na Filozofskom fakultetu Sveučilišta u Zagrebu. Glavna je urednica časopisa Suvremena lingvistika i zamjenica voditelja doktorskog studija lingvistike. Objavila je tri knjige i niz radova u domaćim i međunarodnim časopisima. Od akademske godine 2013/2014. do 2017/2018. obavljala je dužnost pročelnice Odsjeka za lingvistiku. Voditeljica je bilateralnog projekta Odnos slike i teksta u reklamama u tisku s Odsjekom za lingvistiku Sveučilišta u Beču (2015-2017). Kao glavni istraživač u Hrvatskoj od 1. ožujka 2016. do 1. ožujka 2019. sudjelovala je u provedbi projekta iz okvira Obzor2020 ACCOMPLISSH - ACcelerate CO-creation by setting up a Multi-actor PLatform for Impact from Social Science and Humanities. 


\section{SAŽETAK}

Rad se bavi analizom četiri srpska bukvara nastala od 1965. do 2011. godine. Građa je podijeljena na tematske jedinice: etnicitet, rodni i obiteljski odnosi, koje su analizirane pristupom društvenih aktera kroz dijakronijski presjek. Vizualni sadržaji su klasificirani na narativne ili konceptualne reprezentacije, koje su dalje raščlanjivane na aktere, vektore, ciljeve, pratnju i sredstva kod narativnih, tj. na cjelinu i dijelove kod konceptualnih. Analiza je obuhvatila ostvarivanja slikovnog čina i pogleda (direktan ili indirektan pogled), udaljenost (bliska, srednja i dugačka) i izbor horizontalnog i vertikalnog kuta. Modalnost se u analizi odnosi na pouzdanost poruke, koliko je ona istinita, lažna, predstavlja li fikciju i sl. Jezični sadržaji analizirani su kroz pristup društvenih aktera (nominacija, identifikacija, klasifikacija i sl.) i društvene aktivnosti koju oni čine (materijalna, semiotička itd.). Rezultati analize pokazali su da se domovina u bukvarima iz 1965. i 1974. gradi, brani, čuva i voli, dok raspadom SFRJ nestaju državni simboli i domovina se izjednačava sa prirodom. Lik Josipa Broza Tita, smjenjuju Vuk Stefanović Karadžić i Sveti Sava kojima se jača nacionalni identitet. Rodni i obiteljski odnosi u svim bukvarima prikazuju patrijarhalno društvo u kojem je žena vezana uz domenu domaćinstva, pripreme hrane i njege bolesnih, dok je muškarac lovac i pokretač radnje. Interakcije djevojčica i dječaka učestalije su od devedesetih na dalje, ali je dječak i dalje inicijator.

Ključne riječi: Socijalna semiotika, društveni akter, vektor, cilj, modalnost, rodni odnosi, SFRJ 


\section{SUMMARY}

The thesis deals with the analysis of four serbian ABC books, published between 1965. and 2011. Those abc books were used in schools and prescribed by the state administration.

Collected corpus is devided into thematic units: entnicity, gender and generational relashionships, and those are analysed from the aspects of critical discourse analysis, using the social actors approach and social semiotics in diachronic perspective.

Analysis firstly deals with the visual elements and then with the verbal. Visual elements are analysed by dividing it on narrative or conceptual representations. Narrative representations are classified into action, speach or mental process, identified actors, their goals, vectors and accompaniment. Conceptual representations are usually analytical processes which relate participants in terms of a part-whole structure. Interaction between the viewer and depicted image can be realised by direct gaze at the viewer (demand). If there is an absence of gaze at the viewer it is an offer. Interaction is also achieved by using the specific distance: close, middle and long, as well as certain horizontal and vertical angle. Horizontal angle refers to showing depicted image as a part of the viewer's world, and vertical refers to power and who has it. Modality refers to the truth value or credibility of an image, high modality has sharpness, good quality colour palette, depth and everything that modern day photography offers. Modality becomes low when it loses it's sharpnes, clarity, depth etc. Verbal elements are analysed by social actor and social action approach, for an instance are those actors named by their full name, nickname and do they perform material or semiotic social action, is it trasactive or nontransactive etc. Transactive socal action can be interactive (involves human being) and instrumental (doesn't have to involve human).

Taking into account the fact that collected corpus deals wiht the four abc books used in public schools from 1965 to 2011 during the change of social system, government, political reign, this thesis follows how social changes in domain of ethnicity, gender and family relations mirrors in abc books in diachronic perspective.

In ABC books published and used during the socialism era $(1965,1974)$ homeland is visualy depicted by building and restoring country into a modern society that has to be defended, protected and loved. The most prominent figure is the president of the The Socialist Federal 
Republic of Yugoslavia (SFRY) who was also a commander-in-chief of The Yugoslav People's Army Josip Broz Tito. He takes the possition of the very begginig. When an actor, his goal are children, he is depicted from frontal horizontal angle and vertical on the eye level which sends a message „he is the one of you and belongs to your world“. When shown in the company of the pupils, he is dressed in a civil suit, but in the presence of pioneers he wears a uniform. In verbal content he is nominated by his full name and presidental funcition and is also present as Tito (nickname). He is classified as the oldest in the Army as it's maker. He is depicted as an warrior, protector and a man who is loved and respected by everyone. The main motto We are Tito's-Tito is ours demonstrates mutual belonging. In the 1974 ABC book he is dressed in the uniform and surrounded by pioneers. He is their commander-in-chief on two level - as a president of the state and as a head of the Army. Visual analysis of the ceremony of becoming a pioneer is showed as a kind of initiation, a way of stepping into the world of adults. Pioneer's hats are represented in green colour, instead of blue, which serves as a connection with partisans who liberated the country in the Second World War. This sends the message that every pioneer is a descendant of partisan and also potential member of Yugoslav People's Army. In the ABC books from socialist era Army functions as Yugoslav People's Army and as an army formed by children who plays with brooms, sticks etc. In verbal content Tito is not only a president, by the end of the ABC book from 1974 he becomes a child, is called little Joža, he is reckless and playfull as any other child. In the ABC book from 1996, which is published after the desintegration of SFRY there are no Tito, army, pioneers, but no new state symbols including a flag. Homeland is visualy depicted as nature itself, it is almost like a planet Earth. In the ABC book from 2011 homeland is fonud in the context of any other love, to natural beauty and people we are close with. Besides that homeland context has changed and almost vanished there is a prominent emphasising of serbian national identity by using the image of Vuk Stefanović Karadžić (serbian language reformer and collector of folk literature) and Saint Sava (the first serbian archbishop). Vuk Karadžić takes over Tito's place in ABC books, his presence shows offer, he has a serious face expression asking for respect from a viewer. He is not continuously showed from frontal horizontal angle, there is an one example of partly leaning horizontal angle because he belongs to the past time. Nevertheless, he carries out fondness with the viewer by being framed in oval shape frame which looks like an old family photograph. His wardrobe is important because it has an elements of folk costume, his hat for an instance, which suits him as a collector of folk literature. He is mainly showed as an old man which stresses out his knowledge, authority and wisdom. In the ABC book from 1996 Saint Sava is not visually 
present, he is the main actor in the folk story which describes him as an wise teacher, but in the later book from 2011 he is presented as a fresco image form Mileševa Monestary which is important for forming a cult of him as a saint. Showing him as a saint in $\mathrm{ABC}$ book form 2011 can be explained by stronger influence of The Serbian Orthodox Church in society.

Gender relations are analysed in the similar order as ethnicity, firstly visual and then verbal content. Analysis deals with the standalone representation of the girls, then standalone boys and thier interaction chronologicaly from 1965 to 2011 ABC book. Boys dominante in the ABC book from 1965 even if they are shown alone, or playing with each other. When boys and girls are together they are performing school activities or imitating adults where boys are in charge. Vectors used by girls are flowers, decorating branches, whereas boys use lots of tools, weapons and objects with practical purpose. Goals toward girls direct their action are toys, decoration and cleaning objects, while boys are directed toward animals, toys like ball, kit, rocket etc. Interaction with the viewer is accomplished with demand, frontal horizontal angle, vertical angle on the eye level which sends the message ,This is how we play and do things just like you/You can play and do all those things as well.“ Despite new legal rights and emancipation of women in post war society gender rolls are very traditional. Girls are acting and looking like mothers considering their clothes and the fact they take care of others. On the other hand, boys dominante as hunters, fishermen, adventurers and at the and as action initiators. Analyzing verbal content we see that girls are depicted as good girls, excelent in school achievements while boys are involved in sports. Social action is particulary common for boys and they are involved in all sorts of material actions including transactive, interactive and instrumental action. Semiotic social action is not that present, only in werbs want and dream. When boys and girls are included in the same social action, they are present as pioneers or pupils in school.

Boys and girls are not higly represented in the ABC book from 1975 because adults besides family dominate. Girl is present as an actor in the roll of a Red Riding Hood and as an interactor where to girls are goal for each other. Their wardrobe is the same as in 1965, they have long hair and wear skirts and dresses. They are in involved in material transactive social action about food preparation, making cake and asking for an advice. Semiotic social aciton is present in one example when she doesn't like cake recipe. When depicted visualy boys are present in action and speach process. His vectors are fishing stick, newspapers, and goal is the fish. There, we see he is still a hunter. Speaking of interaction, there are examples of offer and demand, and continuously usage of frontal horizontal angle and vertical is on the eye level. It is the same 
when boys and girls are presented together, and their vecotrs are hands. Boys and girls envolved in common activities perform material social action by drawing, having pen etc.

ABC book from 1996 presents both genders more often in action process. When girls are actors they have a flower as a vector, and their goals are flower, butterfly, bird. On the other hand goals for boys are pieces of paper, ball, kit, other boys, bird etc. His means are scooter and a stick. When both genders are together we see them from long distance to have a better understanding of their positions in space. Horizontal and vertical angle is the same as in the previous $\mathrm{ABC}$ books. When they play together their goals are the same: bird, tree, letters, but they are not equally active - he climbs the tree but she just touches it. His means are some kind weapons and her's are flowers and musical instrument. Female wardrobe is the same as in the previous ABC books. When boys and girls are verbaly described common is the use of adjective small. When they are identified by function boys are friends, bakers, thiefs, princes and girls are princesses. Considering emotions she displays anger and both of them fall in love but only in a dream when in the roles of prince and princess.

ABC book from 2011 is very similar considering vectors and goals for both genders as well as verbal representation. The most prominent novelty is the presence of boys and girls sitting together in school classroom. There are changes in wardrobe because girls wear trousers during winter. Verbal content is the same as in the previous $\mathrm{ABC}$ book.

Family in ABC books consists of mother, father, children, usually boy and girl, and grandparents. In the ABC book from 1965 mother is involoved in action such as cooking, taking care of children and household. Her vectors are hands and ladle, goals are casserole, child, sewing machine, seller at the open market etc. Girl is also attached to cooking, taking care of others and helping, just like grandmother. Father is only once present where he cuts bread and is the only one family member who sends demand to the viewer, certenly as a head of family. Gradfather is visualy represented with gray mustache and he keeps them in all ABC books. In the ABC book from 1974 there are only two family portraits and one action process. Action process depicts mother and daughter in a full colour photography where they share a hug. There is a rare example of partly low vertical angle, because the viewer is put in the possition of admireing their love. Grandfateher and grandson as an actors have a the same goal, tree they plant. Most of the family members engage in interacition with the viewer giving direct gaze (demand). Mother is not so involved in cooking but she is still tied to taking care of children. Considering mutal relations there are no relations between father and daughter and grandfather and granddaughter. In the $\mathrm{ABC}$ book from 1996. Mother is still present in food prepairing 
domain, as daughter. Boy is still a hunter and adventurer. Brother and sister are interactors holding hands with each other. All actors are presented from long distance, but horizontal and vertical angle place them in the viewer's world. Interaction with direct gaze send boy and girl because they are connecting with their peers. Father and son play chess, father and daughter go to buy books, and relationship between grandfahter and granddaughter is nonexistent. $\mathrm{ABC}$ book from 2011. brings changes in female wardrobe and hairstyle. Mother wears trousers, and has a shorter hair just like grandmother does. Grandfather keeps his gray mustache which makes him look like Vuk Karadžić. Mother is still taking care of household, daughter is ready to help in, grandfather tells the stories to his grandson, father makes telephone calls and fixes the car. Mutual relations are present between all family members exept grandaughter and gradfahter.

To sum up gender relations on repeating characteristics we see that female gender is tied to the earth by flowers, food, helping wounded etc. Male gender including boy and the father are hunters and grandfather is someone who possess wisdom and storytelling skills. Inseparable connection between woman and earth can be traced back to matriarchy residues in the society with defined patriarchal roles because woman was the one who first discovered plants. At the end we can say that social and political changes like regime change are quickly applied so state symbols and historical figures replace one another. On the other hand, gender relations in ABC books are less likely to follow society changes because woman is still inseparable from earth and man is a hunter.

Key words: social semiotics, social acter, vector, goal, modality, gender relations, SFRY 


\section{SADRŽAJ}

I KRATAK PREGLED VAŽNIJIH SRPSKIH BUKVARA

II DRUŠTVENO-POVIJESNE PRILIKE 1965-2011

Nastanak SFRJ i poslijeratna obnova $\quad 5$

$\begin{array}{ll}\text { Razvoj industrije, napuštanje sela i razvoj grada } & 7\end{array}$

$\begin{array}{ll}\text { Kratka povijest pionira } & 8\end{array}$

Tito - vrhovni komandant narodnooslobodilačke vojske, maršal, predsjednik 10

Buđenje vjerskih zajednica, raspad SFRJ i srpsko društvo u tranziciji 12

POLOŽAJ ŽENA U VREMENU OD 1965. DO 2011.

$\begin{array}{ll}\text { Zakonski okvir } & 14\end{array}$

$\begin{array}{ll}\text { Obrazovanje } & 15\end{array}$

$\begin{array}{ll}\text { Zapošljavanje žena } & 16\end{array}$

POVIJESNE LIČNOSTI IZVAN VREMENA 1965-2011. 18

$\begin{array}{lr}\text { Sveti Sava } & 18\end{array}$

$\begin{array}{ll}\text { Vuk Karadžić } & 19\end{array}$

III SOCIJALNO SEMIOTIČKI PRISTUP ANALIZI 22

1. Analiza slikovnog sadržaja 22

1.2. Teorijsko-metodološki okvir 22

$\begin{array}{ll}\text { 1.3. Narativne reprezentacije } & 24\end{array}$

1.4. Konceptualne reprezentacije 25

$\begin{array}{ll}\text { 1.5. Interakcija } & 25\end{array}$

1.6.Modalnost 26

2. Analiza jezičnog sadržaja 26

2.1. Teorijsko-metodološki okvir 26

2.2. Društveni akteri 27

2.3. Društvena aktivnost 28

IV SOCIJALNO SEMIOTIČKA ANALIZA 30

1. Etnicitet 30

1.2.Povijesne osobe 
1.2.1. Analiza slikovnog sadržaja u bukvaru iz 1965. godine 30

1.2.2. Analiza jezičnog sadržaja u bukvaru iz 1965. godine 32

1.2.3. Analiza slikovnog sadržaja u bukvaru iz 1974. godine 33

1.2.4. Analiza jezičnog sadržaja u bukvaru iz 1974. godine 34

1.2.5. Analiza slikovnog sadržaja u bukvaru iz 1996. godine 34

1.2.6. Analiza jezičnog sadržaja u bukvaru iz 1996. godine 36

1.2.7. Analiza slikovnog sadržaja u bukvaru iz 2011. godine 37

1.2.8. Analiza jezičnog sadržaja u bukvaru iz 2011. godine 39

$\begin{array}{ll}\text { 1.3.Koncept domovine } & 40\end{array}$

1.3.1. Analiza slikovnog sadržaja u bukvaru iz 1965. godine 40

1.3.2. Analiza jezičnog sadržaja u bukvaru iz 1965. godine 43

1.3.3. Analiza slikovnog sadržaja u bukvaru iz 1974. godine 44

1.3.4. Analiza jezičnog sadržaja u bukvaru iz 1974. godine 47

1.3.5. Analiza slikovnog sadržaja u bukvaru iz 1996. godine 47

1.3.6. Analiza jezičnog sadržaja u bukvaru iz 1996. godine 48

1.3.7. Analiza slikovnog sadržaja u bukvaru iz 2011. godine 48

1.3.8. Analiza jezičnog sadržaja u bukvaru iz 2011. godine 48

1.3.9. Zaključne napomene $\quad 49$

2. Rodni i međugeneracijski odnosi 54

2.1. Samostalni prikazi djevojčica 54

2.1.1. Analiza slikovnog sadržaja u bukvaru iz 1965. godine 54

2.1.2. Analiza jezičnih sadržaja u bukvaru iz 1965. godine 55

2.1.3. Analiza slikovnog sadržaja u bukvaru iz 1974. godine 55

2.1.4. Analiza jezičnog sadržaja u bukvaru iz 1974. godine 57

2.1.5. Analiza slikovnog sadržaja u bukvaru iz 1996. godine 57

2.1.6. Analiza jezičnog sadržaja u bukvaru iz 1996. godine 59

2.1.7. Analiza slikovnog sadržaja u bukvaru iz 2011. godine 59

2.1.8. Analiza jezičnog sadržaja u bukvaru iz 2011. godine 60

$\begin{array}{ll}\text { 2.2. Samostalni prikazi dječaka } & 60\end{array}$

2.2.1. Analiza slikovnog sadržaja u bukvaru iz 1965. godine 60

2.2.2. Analiza jezičnih sadržaja u bukvaru iz 1965. godine 62

2.2.3. Analiza slikovnog sadržaja u bukvaru iz 1974. godine 63

2.2.4. Analiza jezičnog sadržaja u bukvaru iz 1974. godine 64

2.2.5. Analiza slikovnog sadržaja u bukvaru iz 1996. godine 64

2.2.6. Analiza jezičnog sadržaja u bukvaru iz 1996. godine 68

2.2.7. Analiza slikovnog sadržaja u bukvaru iz 2011. godine 69

2.2.8. Analiza jezičnog sadržaja u bukvaru iz 2011. godine 73

$\begin{array}{ll}\text { 2.3. Djevojčice i dječaci zajedno } & 74\end{array}$

2.3.1. Analiza slikovnog sadržaja u bukvaru iz 1965. godine 74

2.3.2. Analiza jezičnog sadržaja u bukvaru iz 1965. godine 78

2.3.3. Analiza slikovnog sadržaja u bukvaru iz 1974. godine 79

2.3.4. Analiza jezičnog sadržaja u bukvaru iz 1974. godine 81

2.3.5. Analiza slikovnog sadržaja u bukvaru iz 1996. godine 83

2.3.6. Analiza jezičnog sadržaja u bukvaru iz 1996. godine 90 
2.3.7. Analiza slikovnog sadržaja u bukvaru iz 2011. godine

2.3.8. Analiza jezičnog sadržaja u bukvaru iz 2011. godine

2.3.9. Zaključne napomene

2.4.1. Analiza slikovnog sadržaja u bukvaru iz 1965. godine

2.4.2. Analiza jezičnog sadržaja u bukvaru iz 1965. godine

2.4.3. Analiza slikovnog sadržaja u bukvaru iz 1965. godine

2.4.4. Analiza jezičnog sadržaja u bukvaru iz 1974. godine

2.4.5. Analiza slikovnog sadržaja u bukvaru iz 1996. godine 


\section{KRATAK PREGLED VAŽNIJIH SRPSKIH BUKVARA}

Bukvar je udžbenik koji služi opismenjavanju, savladavanju čitanja i pisanja u nastavi materinjeg jezika. Nekada je bukvar predstavljao prvi susret sa knjigom, s pisanom riječju, a gledano kroz povijest sam proces savladavanja ovih vještina nije bio ni približno lagan, zabavan niti praćen ilustracijama kao što je to danas. Uzevši u obzir složenu povijest razvoja srpskog književnog jezika, u kojoj su kroz različita razdoblja dominirali srpskoslovenski, ruskoslovenski slavenosrpski i na kraju narodni jezik, ${ }^{1}$ bukvari su nastojali pratiti ove promjene, s manje ili više uspjeha.

U ovom poglavlju daje se kratak osvrt na srpske bukvare koji imaju povijesni značaj, uvode novi književni jezik, koji su ostavili traga u metodološkom smislu ili su svojom koncepcijom utjecali na kasnije bukvare. Na kraju se navode bukvari koji ulaze u korpus istraživanja ovoga rada.

Prvi srpski štampani bukvar jest Bukvar Inoka Save, koji iz manastira Dečani odlazi u Veneciju i u tisak daje četiri lista bukvara 1597. godine. Ovaj bukvar predstavlja azbuku srpskoslavenske ćirilice, u njemu se navode suglasnici u slogu s vokalom, a na kraju slijedi molitva Oče naš (Čigoja 2010: 517). Zanimljivo je spomenuti da se kroz srednji vijek u Evropi za opismenjavanje koristi metoda sricanja kod koje se prvo slova imenuju u slogovima, a pisanje je donekle sporedno i uči se kasnije - preslikavanjem slova (Ćunković 2010: 313). Savin Bukvar pak pripada glasovnoj sintetičkoj metodi kod koje se „glas i slovo uče istovremeno, dok se izdvajanjem samoglasnika iz azbuke ističe njihova uloga u vezivanju suglasnika u slogove, odnosno reči“ (Mano-Zisi 2010: 17). Dakle, u metodološkom smislu, Savin bukvar je vrlo revolucionaran, ali na žalost $\mathrm{u}$ tom pravcu nije utjecao na kasnije bukvare. Treba spomenuti još jedan bukvar napisan na srpskoslavenskom jeziku, a to je prvi srpski rukopisni bukvar Gavrila Stefanovića Venclovića iz 1717. godine.

Period opismenjavanja Srba na ruskoslavenskom jeziku (ruska redakcija staroslavenskog) počinje dolaskom učitelja iz Rusije, Maksima Suvorova, koji donosi 400 primjeraka bukvara Teofana Prokopovića Pervoe učenie otrokom štampanog u Moskvi, 1724. godine. Ovaj bukvar

\footnotetext{
${ }^{1}$ Opširnije o standardnim jezicima kod Srba u poglavlju br. 2, v. Vuk Karadžić.
} 
nudi učenje slova metodom sricanja, daje azbuku sa imenima slova, vjerske pouke i molitve. Koristio se u nastavi kroz cijelo 18. stoljeće, preštampavan je više puta u Beogradu, Novom Sadu, Cetinju, a novi bukvari koji nastaju u tom periodu rađeni su po ugledu na njega (Ćunković 2010: 315).

U Veneciji 1767. izlazi bukvar Zaharija Orfelina na ruskoslavenskom jeziku, a izdvaja se od ostalih iz tog perioda time što daje pregled i ruske građanske ćirilice (Čigoja 2010: 525). Osim azbuke, Orfelin daje i upute za lakše savladavanje slova. Svjestan je nepodesnosti metode sricanja, pa predlaže da se učenici igraju slovima nacrtanima na kartonima, da ih učitelj provjerava tako što traži da mu donesu određeno slovo i svaki točan odgovor nagradi slasticom -- kolačem ili voćem. Ovakvom metodom, azbuka se može naučiti za samo 15 dana, smatra Orfelin (Ćunković 2010: 317).

Prvi srpski bukvar na narodnom jeziku (koji postaje i standardni), napisan reformiranom ćirilicom, potpisuje Vuk Karadžić. Štampa ga u Beču 1827. godine pod nazivom Prvi srpski bukvar. Poput svojih prethodnika i Vuk je bio svjestan teškoća koje su nastupale učenjem slova metodom sricanja, pa tako već na uvodnim stranicama daje konkretne savjete učiteljima u opismenjavanju „valja da mu ne kazuje nikakva imena slova, nego samo njihove glasove, koje imaju u čitanju, pa onda nema sricanja nego, kako se poznadu slova, odma se može čitati. Tako može čovek vrlo lasno za deset dana naučiti čitati!“ (Karadžić 1827: 3).

Nakon što je u Srbiji i službeno usvojena Vukova reforma ćirilice, Ministarstvo prosvjete kneževine Srbije je 1869. godine raspisalo natječaj za novi bukvar s čitankom koji bi ispunio sve zahtjeve školovanja u novonastalim okolnostima. Na natječaju je pobijedio Đorđe Natošević i njegov Bukvar za osnovne srpske škole ubrzo dobiva tri verzije; za Srbiju, Crnu Goru i Ugarsku. Iako izdavanje bukvara za Ugarsku nije uspjelo, Natošević je uspio izdati bukvar za srpske škole u Vojvodini. Izdanje za Srbiju štampano 1870. godine doživjelo je više kasnijih izdanja (Ćunković 2010: 324). Ovaj bukvar čini prijelomnu točku iz više razloga: predstavlja pobjedu reformirane ćirilice u nastavi, definitivno napuštanje metode sricanja, uvođenje metode normalne riječi i postavljanje standarda u koncepciji bukvara. Gradivo čine elementi za pisanje, slike riječi pored kojih se nalazi štampano i pisano slovo, a ispod su riječi i rečenice. Na kraju bukvara nalaze se tekstovi za vježbanje čitanja (ibid. 326).

U periodu između dva svjetska rata dolazi do razvoja metoda učenja slova, pa tako dotadašnja metoda normalne riječi prerasta u tzv. glasovnu analitičko-sintetičku metodu, koja je i danas prisutna u srpskim bukvarima. Ilustracije postaju sve prisutnije uz tekst, udžbenik se želi učiniti 
što atraktivnijim i zanimljivijim, pa se daju slike za dopunu rečenica, ostavljaju se i praznine za samostalno dopisivanje riječi - čime se postiže veći angažman učenika, a javljaju se i prvi mali stripovi. Izlaze bukvari za opismenjavanje odraslih, kao i oni za samostalno savladavanje slova (Ćunković 2010: 332). Nakon Drugog svjetskog rata nastavlja se po već uhodanim metodama bukvarske nastave, s time da je svaka republika zajedničke države izdavala svoje bukvare (ibid. $338)$.

U ovome će se radu analizirati četiri srpska bukvara nastala u periodu od sredine šezdesetih godina prošlog stoljeća do 2011. godine:

1. Mita Mitić: Bukvar za I razred osnovne škole, uporedna obrada štampanih i pisanih slova, drugo izdanje, Zavod za udžbenike Socijalističke Republike Srbije, Beograd, 1965.

2. Desanka Stojić-Janjušević, Vladimir Milardić, Božidar Timotijević: Moja prva knjiga, Bukvar za prvi razred osnovne škole, treće izdanje, Narodna knjiga, Beograd, 1974.

3. Vuk Milatović, Anastasija Ivković: Bukvar za prvi razred osnovne škole, deveto izdanje, Zavod za udžbenike i nastavna sredstva, Beograd, 1996.

4. Vuk Milatović, Anastasija Ivković: Bukvar, Zavod za udžbenike. Beograd, 2011.

Sva četiri predstavljaju službene bukvare koji su se koristili u prošlosti ili se koriste danas u školama u Srbiji uz odobrenje nadležnog ministarstva. Bukvari su uglavnom strukturirani tako da se sastoje od tri dijela: predbukvarski dio - priprema za čitanje i pisanje; bukvarski dio učenje čitanja i pisanja; postbukvarski dio - uvježbavanje naučenog kroz tekstove (Mrkalj 2010: 274), od čega ne odstupaju ni ova četiri koja ulaze u korpus.

Mitićev bukvar iz 1965. godine koristio se na području Srbije, sve dok ga 1974. nije zamijenio novi bukvar. Knjiga je bogato ilustrirana slikama u boji i paralelno daje štampana i pisana slova. Prvih 17 stranica posvećeno je uvježbavanju pisanja kosih i ravnih crta, kao priprema za pisanje slova. Na kraju se nalaze tekstovi za uvježbavanje čitanja. Bukvar grupe autora StojićJanjušević, Milardić i Timotijević koji izlazi 1974. koristi se sve do početka devedesetih godina, koje obilježava raspad SFRJ. Ovdje se isto usporedno uče štampana i pisana slova, ali nema predbukvarskog dijela, nego se odmah kreće s učenjem slova. Slova se uvježbavaju kroz zadatke u kojima se dopisuje slovo ili riječ koja nedostaje. Prema ustaljenoj koncepciji, tekstovi dolaze na kraju. Bukvar Vuka Milatovića i Aanstasije Ivković iz 1996. godine vraća predbukvarski dio, nakon čega se počinju učiti slova - paralelno štampana i pisana. Bogate 
ilustracije, slike koje traže opisivanje događaja, zadaci s dopisivanjem i tekstovi su na kraju. Isti autori potpisuju bukvar iz 2011. godine, u kojem tekstove ne mijenjaju, ali ilustracije dobivaju potpuno drugačiji izgled. Od 2003. godine Zavod za udžbenike nije više jedini izdavač koji priređuje i štampa bukvare, jer se na tržište plasiraju i drugi uz odobrenje komisije Ministarstva prosvjete Republike Srbije (Mrkalj 2010: 274). 


\section{DRUŠTVENO-POVIJESNE PRILIKE 1965-2011.}

U razdoblju od 1965. do 2011. godine Srbija se našla u sastavu četiri države prešavši iz jednostranačkog u višestranački sustav, promijenivši izgled zastave i grba, odnos prema religiji i prošavši kroz velike društvene i ekonomske promjene. U ovom poglavlju ne daje se kronologija svih društveno-političkih događaja, nego se daje kraći povijesni pregled koji pripada kontekstu tema koje su u narednim poglavljima predmet analize bukvara nastalih od 1965. do 2011. godine.

\section{Nastanak SFRJ i poslijeratna obnova}

Po završetku Drugog svjetskog rata ukinuta je monarhija, Jugoslavija je proglašena republikom te su promijenjeni državni simboli. Prema Ustavu Federativne Narodne Republike Jugoslavije (FNRJ), iz 1. 2. 1946., zadržane su boje i redoslijed zastave Kraljevine Jugoslavije - plava, bijela i crvena, a u sredinu je stavljena crvena zvijezda petokraka. Zastava je ostala nepromijenjena sve do početka devedesetih godina, kada se nekadašnje jugoslavenske republike odvajaju i SFRJ prestaje postojati. ${ }^{2}$

Naziv Socijalistička Federativna Republika Jugoslavija (SFRJ) službeno se uvodi ustavom iz 1963. godine, koji je Skupština usvojila 7.4.1963. Ustav je poznat pod nazivom „Povelja samoupravljanja“ jer se model samoupravljanja odnosio na sve sfere društvenoga života. „Ustav je polazio od čoveka - građanina i proizvođača - od slobodno udruženog rada, društvene svojine i raspodele prema radu. Rad je proglašen za jedino merilo čovekovog materijalnog i društvenog položaja“ (Petranović 1988: 544). Kolektivi u ustanovama dobivaju status radnih organizacija, a po pitanju prava izjednačeni su s radnim organizacijama u gospodarstvu. „Ustav je proglasio da građani neposredno i preko organa društvenog samoupravljanja ostvaruju osnovne funkcije društvene zajednice koja se definira kao slobodna zajednica proizvođača “(Matković 1998: 341).

\footnotetext{
${ }^{2}$ http://www.arhivyu.gov.rs/active/srlatin/home/glavna_navigacija/leksikon_jugoslavije/drzavni_simboli/zastava.
} html) 
Završetak Drugog svjetskog rata jugoslavensko stanovništvo dočekalo je uz ogromne ljudske gubitke, u zemlji razrušenoj višegodišnjim ratovanjem, s uništenim prometnicama i industrijom. Jugoslavija je bila jedna od najrazorenijih zemlja u Evropi, odmah nakon tadašnjeg SSSR-a i Poljske. Nova vlast odmah je pokrenula obnovu zemlje, posebno popravak pruga kako bi se hrana mogla dopremati u najugroženije krajeve. Radovi na pruzi Beograd-Zagreb počeli su već pomicanjem fronta prema zapadu, pa je prvi vlak iz Zagreba u Zemun stigao sredinom lipnja 1945. godine (Petranović 1988: 79-80).

Kako je zemlja bila osiromašena i materijalno devastirana, vlast je jedini način obnove vidjela kroz organiziranje masovnih radnih akcija na kojima su postojala takmičenja u prebacivanju norme. Za samoprijegoran rad stjecalo se udarničko zvanje. Petranović navodi kako gradnjom pruge Brčko-Banovići 1946. otpočinju velike savezne akcije u kojima većinom sudjeluju mladi ljudi, čak i oni iz drugih zemalja. Dužina spomenute pruge iznosila je $92 \mathrm{~km}$, a sama pruga često se nazivala omladinskom jer je izgrađena zalaganjem omladine. U velike akcije spada i auto-put Beograd-Zagreb, koji je kasnije nazvan Auto-put bratstva i jedinstva (Petranović 1988: 85). Izgradnja pruge Šamac-Sarajevo predstavljala je najveći projekt prvih godina petogodišnjeg plana obnove zemlje. Cijela dužina od $242 \mathrm{~km}$ izgrađena je angažiranjem preko 6000 mladih, od 1. travnja do 15. studenog 1947. Radilo se u duhu udarništva, uz parole koje su davale dodatnu motivaciju: Mi gradimo prugu - pruga gradi nas; Šamac-Sarajevo, to je naša meta: izgraditi prugu još ovoga leta; Udarna brigada će sve da svlada; Druže Tito, samo reci, ostajemo šest meseci. Zanimljivo je spomenuti i da je u ovoj akciji udarničko zvanje dobila čak brigada tzv. beogradski besprizorni, u koju su spadali besposličari, sitni lopovi, preprodavači kino ulaznica i dr. (Petranović, 1988: 96).

Fenomen radnih akcija može se promatrati s aspekta moralne ekonomije dara, i u takvoj postavci po srijedi je svojevrsno oduživanje za slobodu: ,njihovi radni uspjesi, ,,samoprijegorna darivanja“, gotovo uvijek već bili uzvraćanje Komunističkoj partiji, Titu i državnom vodstvu ili sistemu za dar slobode izboren u NOB-u. Stoga je njihova dominantna referentna točka, a s njome i barem deklarativna motivacija za pregalaštvo, uvijek superiorna, jer se dar slobode, poput dara života, ničime ne može uzvratiti“ (Matošević, 2016: 65).

Procjenjuje se da je 1947. godine vrijednost samo omladinskih radnih akcija iznosila 13\% ukupne izgradnje (Petranović 1988: 97). Već dvije godine po završetku Drugog svjetskog rata postojeća je privreda uglavnom bila obnovljena i počelo se sa izradom dugoročnijih strategija razvoja. Prvi petogodišnji plan odnosio se na period od 1947. do 1952. godine te je uključivao 
velike investicije poput izgradnje elektroindustrije, proizvodnju energije, željeza, čelika, uglja, izgradnju brodogradilišta itd. (Čalić 2013: 242). Ostvarenjem ovih velikih projekata Jugoslavija je u šezdesete godine ušla kao društvo koje je bilo na korak od potpune transformacije u industrijsko.

\section{Razvoj industrije, napuštanje sela i razvoj grada}

Šezdesete godine često se nazivaju ,zlatnim dobom“ Jugoslavije, jer posljedice rata već su uvelike bile sanirane, postignute su veće intelektualne slobode, a otvaranje međunarodne razmjene utjecalo je na razvoj umjetnosti i kulture. Rasla je potrošnja i pred građanima su se otvarale do tada nezamislive mogućnosti, zbog čega je ovo vrijeme i nazvano ,zlatnim“. MariŽanin Čalić u djelu Istorija Jugoslavije navodi kako se „kritička samorefleksija, želja za promenom i ostvarenjem pretvorila od elitne u masovnu pojavu - što je možda odlučujuća karakteristika ove decenije“" (Čalić 2013: 253).

Gornji građanski slojevi u jugoslavenskom društvu više nisu postojali, seljaci postaju industrijski radnici ili se zapošljavaju u sektoru usluga. Kada se usporedi 1947. godina s 1965. godinom, vidi se da je industrijska proizvodnja uvećana za više od šest puta. Još prije početka Drugog svjetskog rata počela je nastajati klasa radnika-seljaka, koja razvojem industrije i rudarstva postaje sve zastupljenija u Jugoslaviji (Čalić 2013: 254). Početkom šezdesetih godina skoro $40 \%$ zemljoradnika za život je zarađivalo u nekoj mjeri izvan vlastitog imanja. Život na selu bio je težak, posebno rad na polju, jer se i dalje sve radilo ručno ili uz pomoć volovske ili konjske zaprege. Traktore je u to vrijeme imalo tek 3000 privatnih posjednika u čitavoj Jugoslaviji. Tek sedamdesete godine donose masovnu upotrebu mehanizacije u poljoprivredi, pa je 1975. u upotrebi bilo više od 200000 traktora. Seljaci koji bi se zbog posla u tvornici preselili u gradove, uglavnom su brzo usvajali industrijski način života - posebno žene, koje bi u selu, kao dominantno patrijarhalnoj sredini, imale negativnu reputaciju zbog rada za nadnic. (Čalić 2013: 255-256).

Između 1945. i 1979. godine oko 5,5 miliona ljudi napušta selo, a najveći priljev stanovništva u gradove desio se upravo tokom šezdesetih godina. Glavni grad, Beograd, 1969. godine imao je već više od milion stanovnika, i u to vrijeme svaka dva od tri stanovnika potječu iz provincije (Čalić 2013: 257). U cijeloj Jugoslaviji gradovi se razvijaju, u njima se podižu nova naselja specifičnog socijalističkog urbanizma, koji karakteriziraju „funkcionalna i monotona naselja 
stambenih blokova, izgrađena međusobno udaljena na velikom prostoru i sa mnogo zelenih površina, kako bi narodne mase dobile higijenski smeštaj koji bi mogle da plate" (Čalić 2013: 258). Unatoč tomu, u velikim gradovima vlada nestašica stambenog prostora i u jednom stanu živi i po nekoliko obitelji. U samom Beogradu je sredinom šezdesetih nedostajalo 50000 stanova (ibid. 260).

Sedamdesete godine Jugoslaviji, kao i ostatku Evrope, donose fazu recesije, naftnu krizu i propadanje čitavih privrednih grana, ali i jačanje sektora usluga. Ustav SFRJ mijenja se 1974. godine i Tito biva proglašen doživotnim predsjednikom. Mari-Žanin Čalić navodi kako je „princip rotacije na vodećim funkcijama onemogućavao svaki pokušaj potencijalnih naslednika da sebi prigrabe nasleđe ostarelog autokrate. Dok su se republike sve više međusobno udaljavale, a sve upravljačke funkcije savezne vlasti gubile se u jednom izuzetno haotičnom političkom sistemu, Titova lična moć rasla je izvan svih granica“ (Čalić 2013: 322).

U osamdesete godine Jugoslavija ulazi kao pravo industrijsko društvo, postotak zaposlenih u poljoprivredi 1981. godine iznosi svega 29\%. Svaki drugi stanovnik živi u gradu, što je puno lakše nego šezdesetih, budući je riješen problem nestašice stanova. Životni standard građana takav je da svaki deseti ima automobil i telefon, a svaki peti televizor. Sastavni dio života čine odlasci na godišnje odmore i putovanja u inozemstvo. Ipak, gospodarski razvoj nije pratio razvoj obrazovnog sustava, koji je već 1980. godine proizveo pola miliona studenata, a samo četiri godine kasnije svaki drugi nezaposleni građanin bio je kvalificiran. Povećava se broj mladih obrazovanih ljudi koji nemaju mogućnost zapošljavanja (Čalić 2013: 346). Kraj osamdesetih donosi urušavanje do tada osnovnih društvenih vrijednosti „kao jednakost, solidarnost i spremnost za žrtvu, najvažnije vrline socijalističkog herojskog kodeksa“ (Čalić 2013: 349).

\section{Kratka povijest pionira}

Odrastanje i školovanje u SFRJ imalo je za ključnu točku primanje u pionire, kada bi se na Dan Republike (29. 11.) organizirala svečanost na kojoj bi učenici prvih razreda osnovnih škola, u plavim hlačama/suknjama i bijelim košuljama, položili pionirsku zakletvu dobivši crvene marame i plave kape s petokrakom zvijezdom. Manifestacija se održala sve do kraja osamdesetih, kada se već naslućivao raspad zajedničke države. 
Prapovijest Saveza pionira Jugoslavije (SPJ) seže u međuratni period i rad dječje grupe Budućnost i dječjih pionirskih grupa, ali tek u vrijeme Narodnooslobodilačke borbe dolazi do ozbiljnog organiziranja, koje predstavlja začetak nove organizacije (Duda 2015: 24). Tokom Drugog svjetskog rata, u organizaciji KPJ, djeca su na oslobođenoj teritoriji pohađala školu, sudjelovala u priredbama, obilazila ranjenike, prikupljala pomoć za borce, a bila su angažirana i kao kuriri, izviđači, bombaši (ibid. 62). Djecu se učilo da razvijaju ljubav prema domovini, partiji, Titu i bratstvu i jedinstvu. Osim toga što se radilo na jačanju osjećaja ponosa, dostojanstva, hrabrosti, poštenja, solidarnosti, istovremeno se razvijala mržnja prema okupatoru. Čak i četiri godine poslije rata u statutu Saveza pionira Jugoslavije stoji da treba poticati mržnju prema neprijatelju koji ometa izgradnju budućnosti, što je u skladu sa tadašnjom pedagoškom politikom koja se ugledala na sovjetsku (ibid. 65). Pedesetih godina element mržnje lagano se ispušta, a šezdesetih više nije prisutan. I dalje se razvija socijalistički patriotizam, poštuje se revolucija, ali se uvode i zabavni sadržaji na kojima se čak počinje inzistirati. Kod djece se potiče radoznalost, kreativni rad i želja za stjecanjem novih znanja. Pojam pionir opisuje se istim odrednicama kao i šezdesetih i sedamdesetih godina - on predstavlja najljepše moralne likove djece u koji su ugrađene najpozitivnije karakterne osobine (ibid. 74). Osamdesete stavljaju akcent na obranu, štedljivost i ekologiju.

\footnotetext{
Pioniri su tako povodom 40. godišnjice SPJ trebali biti osposobljeni za općenarodnu obranu i društvenu samozaštitu (ONO i DSZ) kako bi u slučaju potrebe znali postupati kao njihovi prethodnici u Drugom svjetskom ratu: iznova bi pomagali u izviđanju i uzbunjivanju, njegovanju ranjenika, prikupljanju i dostavljanju hrane, odjeće, sanitetskog i drugog materijala, ometali bi neprijateljsku djelatnost i kao kuriri pomagali jedinicama JNA i Teritorijalne obrane. (ibid. 75)
}

Ekonomska kriza nametnula je razvijanje štedljivosti, djecu se usmjeravalo da racionalnije koriste školski pribor i pravilno se odnose prema vlastitoj i društvenoj imovini. Pionir je osamdesetih godina bio ekološki osviješten jer ga se učilo ne samo da upoznaje i voli prirodu nego i da se s brigom odnosi prema okolišu prenoseći to znanje i na svoju lokalnu zajednicu (ibid.75). U Srbiji je ipak ranije, šezdesetih godina, osnovan Pokret mladih Gorana, čiji je zadatak bio također ekološki, ali dominantno usmjeren na pošumljavanje.

Kada je riječ o obilježjima i simbolima, začeci sežu u međuratni Sovjetski savez i u NOB, kada djeca sudionici borbe nose crvenu maramu i bijelu kapu (ibid. 116). Uniforme koje su podrazumijevale plave hlače ili suknje, bijele košulje, crvenu maramu i plavu kapu sa zvijezdom petokrakom, ustalile su u Jugoslaviji šezdesetih i održale u toj formi sve do kraja osamdesetih godina. Odora pionira tako je oponašala boje jugoslavenske zastave (Duda 2015: 
117) Za crvenu maramu se također vezuje simbolika - tri kuta marame predstavljala su jedinstvo djece, omladine i odraslih. U početku marame nisu u svim republikama bile crvene, ali je naposljetku ova boja prevladala jer je potjecala s pionirske zastave, a jednako crvene su bile i partijska i proleterska zastava. (ibid. 119). Jedna od verzija detaljnijeg opisa pojma pionir, svakom slovu te riječi pridavala je poželjnu osobinu djeteta: pošten, iskren, napredan, istrajan, radišan (ibid. 2015: 59).

U Jugoslaviji se od druge polovice pedesetih godina svaki 25. svibnja, Titov rođendan, slavio kao Dan mladosti, a manifestacija na kojoj se predsjedniku predavala štafetna palica postala je Štafeta mladosti. Prvi put su pioniri Titu štafetnu palicu predali 1945. u Zagrebu, gdje se zatekao na svoj rođendan. Kasnije su organizirane svečanosti pred Bijelim dvorom u Beogradu, a potom više od dvadeset godina na tadašnjem stadionu JNA u Beogradu, uz prigodni program i slet. Umjetnički oblikovanu štafetu bi predavao najbolji učenik, student ili radnik, uz rođendansku čestitku koja se izgovarala naučena napamet. Nakon Titove smrti, manifestacija se održala do 1987., a već iduće godine program nije uključivao ni štafetu, a ni pionire (ibid. 149).

\section{Tito - vrhovni komandant narodnooslobodilačke vojske, maršal, predsjednik}

Josip Broz Tito neizostavni je akter Drugog svjetskog rata na prostorima koji će kasnije postati SFRJ, a on će do svoje smrti 1980. godine obavljati funkciju predsjednika te države. Budući da se u bukvarima iz 1965. i 1974. godine javlja kao borac u Drugom svjetskom ratu, tvorac vojske i potom predsjednik SFRJ, osvrnut ćemo se ukratko na ove Titove funkcije kroz sažeti slijed društvenih zbivanja.

U svibnju 1940. godine, kada rat već bjesni Europom i Hitler osvaja Nizozemsku, Belgiju i Francusku, Tito organizira i rukovodi V. zemaljskom konferencijom Komunističke partije Jugoslavije (KPJ) u Zagrebu, na kojoj je izabran za generalnog sekretara CK KPJ. Ivo i Slavko Goldstein u knjizi „Tito“ navode kako je to ,prvi put poslije 1920. da je generalnog sekretara izabralo partijsko članstvo, a ne Kominterna, Tito je konferenciju završio riječima: Drugovi, pred nama su odlučujući dani. Naprijed sada, u konačnu borbu. Iduću konferenciju moramo održati u oslobođenoj zemlji od tuđina i od kapitalista.“ (Goldstein 2015:187). Već nekih godinu dana kasnije, Tito ulazak Nijemaca u Zagreb i proglašenje NDH dočekuje upravo u Zagrebu, međutim tek nakon što je Njemačka napala SSSR, 22. lipnja sazrijevaju uvjeti za dizanje narodnog ustanka protiv okupatora. Na sastanku Politbiroa formira se Glavni štab, a 
Tito je imenovan vrhovnim zapovjednikom Narodnooslobodilačkih partizanskih odreda Jugoslavije (NOPOJ) i sve do završetka rata rukovodit će ratnim operacijama, sudjelovati u ofanzivama i dijeliti ratne nedaće sa ostalim borcima. U Enciklopediji Jugoslavije navodi se kako je Tito bio tvorac, organizator i vrhovni komandant vojske u NOB-u, ali istovremeno i glavni rukovodilac političke borbe, budući da je bio na čelu CK KPJ „okupljajući sve rodoljubive napredne elemente i stvarajući na taj način širok narodnoosbodilački pokret“ (Enciklopedija Jugoslavije 2 1956:239). Na drugom zasjedanju AVNOJ-a, u Jajcu, 29. i 30. studenoga, slovenska delegacija predlaže da se Titu dodijeli čin maršala uz obrazloženje da mu se time „odaje zasluženo priznanje za genijalno vođenje operacija NOV-a i partizanskih odreda te za sposobnost i ustrajnost koju je pokazao kod njezina stvaranja i vojno-političkog uzdizanja na današnju razinu“ (Goldstein 2015: 299). Po završetku Drugog svjetskog rata Tito obavlja funkciju predsjednika vlade formirane temeljem odluka konferencije na Jalti, a nakon što Ustavotvorna skupština proglašava FNRJ 29. studenoga 1945. Tito postaje predsjednik Savezne vlade, a od 1953. predsjednik Republike. Autori Goldstein navode kako je i u prvih 25 godina mirnodopske vladavine Tito u svojim rukama imao vojsku, partiju i obavještajne službe, te da se njegova vlast može nazivati autokratskom i autoritarnom jer je imao ničim ograničavanu vlast, ,ali da su se u nekim oblastima društvenog života stvarali značajniji prostori slobode (odnosi unutar obitelji, kultura, znanost), u koje se Tito, a ni vlast u cjelini, nisu previše miješali (iako je i u tim oblastima postojala neposredna društvena intervencija, poput filmske cenzure, ali je s vremenom ima sve manje)“ (Goldstein 2015: 417). Jugoslavenska narodna armija (JNA) svoje korijene nosi iz partizanskih odreda formiranih u NOB-u i prema autorima Goldstein bila je istinsko Titovo čedo kroz koju se provodila jugoslavensko-komunistička politika, a parola Tito - armija, nastala je iz njihovih stvarnih, ali i simboličkih uporišta, budući da su i jedno i drugo bili simbol jugoslavenskog jedinstva. Do kraja života Tito je isticao kako je upravo JNA jamac jedinstva zemlje i kontinuiteta uspostavljenog poretka (Goldstein 2015: 571-574). Definicija JNA u Vojnoj enciklopediji najbolje opisuje ulogu, svrhu i smisao armije u jugoslavenskom društvu jer je ona ,zajednička oružana sila svih naroda i narodnosti i svih radnih ljudi i građana Socijalističke Federativne Republike Jugoslavije. Zajedno s teritorijalnom obranom štiti nezavisnost, ustavni poredak, nepovredivost i celokupnost teritorije SFRJ (Vojna enciklopedija 4, 1972:135.“ Na početku spomenutim ustavom iz 1963. godine, kojim država dobiva naziv SFRJ, razdvaja se i funkcija predsjednika Saveznog izvršnog vijeća od funkcije predsjednika države. Predsjednici Saveznog izvršnog vijeća su se rotirali, a rotacije su se u kasnijim godinama određivale prema nacionalnom ključu, dok je funkcija predsjednika države bila rezervirana za Tita sve do njegove smrti 1980. godine (Goldstein 2015: 608). Tito 
je preminuo uslijed komplikacija nakon teškog operativnog zahvata i umjetnog održavanja na životu punih 68 dana, koje je proveo na aparatima za umjetno disanje. Smrt je nastupila 4. svibnja 1980. i ,premda su mediji prethodnih tjedana i mjeseci sugerirali da su nade u ozdravljenje velike, ili da barem postoje, sve su redakcije bile posve spremne na vijest o smrti - prigodna novinska izdanja i emisije bili su dovršeni već tjednima unaprijed. Iz nadležnih je institucija svim redakcijama poslana i Titova fotografija s tri Ordena narodnog heroja, za koju je bilo rečeno da mora biti objavljena uz vijest o njegovoj smrti“ (ibid. 796). Građani SFRJ danima su se opraštali od Tita, budući da je vlak sa njegovim lijesom putovao od Ljubljane do Beograda, pa su ga spontano ispraćali i stanovnici mnogih okolnih mjesta kroz koja je vlak prolazio. U Zagrebu je bila upriličena velika ceremonija na Tomislavovom trgu, a u Beogradu je lijes bio izložen u Narodnoj skupštini pred kojom se u redu čekalo i po 15 sati. Pogreb je okupio brojne svjetske državnike i oko 700000 građana (ibid. 796).

\section{Buđenje vjerskih zajednica, raspad SFRJ i srpsko društvo u tranziciji}

Već sredinom sedamdesetih godina sociolozi primjećuju lagan porast religioznosti, koji se nastavlja kretati uzlaznom putanjom zahvaćajući i mlađu generaciju. Usporedbe radi, 1967. godine trećina stanovništva Jugoslavije izjašnjavaju se kao vjernici, a dvadeset godina kasnije već više od polovice stanovništva. Čalić navodi kako su propašću socijalističke ideologije nestala i uporišta racionalnog doživljaja svijeta:

\footnotetext{
Na njihovo mesto sada su prodrla izrazito verska tumačenja - tipična ljudska reakcija na iznenadnu propast socijalnog i identitetskog modela. Ponovno buđenje religija zamenilo je proces socijalizacije procesom jačanja zajednice i ponovo aktiviralo veru kao konstitutivni element konstrukcije nacionalnog identiteta. Istovremeno, verske zajednice su aktivno delovale, tako što su svoju naciju proglašavale svetom i rekonstruisale istorijske tradicije. (Čalić 2013: 349)
}

Srpska pravoslavna crkva tako npr. već od kraja šezdesetih postaje vidljivija u javnosti, organizacijom velikih događaja poput procesije s moštima cara Stefana Dušana u Beogradu 1968. godine. Osamstoti rođendan Svetog Save, zaslužnog za samostalnost srpske crkve, svečano je proslavljen 1975., a obilježavan je i Vidovdan - dan bitke na Kosovu (Čalić, 2013: $351)$.

SFRJ je opstala do početka devedesetih, kada počinje razdruživanje, prvo Slovenije i Hrvatske, a potom i ostalih republika. Na teritoriji Hrvatske i Bosne i Hercegovine izbija četverogodišnji 
rat koji za posljedicu ima velika materijalna razaranja, ljudske gubitke i iseljavanje stanovništva.

Na početku 21. veka iz „nasledne mase“ Jugoslavije nastalo je sedam država naslednica: Slovenija, Hrvatska, Bosna i Hercegovina, Srbija, Crna Gora, Makedonija i Kosovo. Više od četiri miliona ljudi izmešteno je radi ostvarenja ideala homogene nacionalne države na prostoru čija je izrazita odlika vekovima bila jedan jedinstveni etničko-kulturni pluralitet. (Čalić 2013: 407)

Formalno razdruživanje jugoslavenskih republika počinje u drugoj polovici lipnja 1991. godine, kada slovenski i hrvatski parlament proglašavaju nezavisnost. Hrvatski sabor 25. lipnja 1991. donosi Ustavnu odluku o suverenosti i samostalnosti Republike Hrvatske ${ }^{3}$, kojom počinje postupak razdruživanja od drugih republika SFRJ i pokreće se međunarodno priznavanje. Republike Srbija i Crna Gora, 27. travnja1992. proglasile su Saveznu Republiku Jugoslaviju, koja je opstala pod tim nazivom sve do 2003., kada je formirana Državna zajednica Srbija i Crna Gora, koja pak opstaje svega tri godine. Zastava Savezne Republike Jugoslavije, kao i potonje zajednice, zadržala je redoslijed boja nekadašnje zastave SFRJ - plava, bijela i crvena, ali je uklonila petokraku zvijezdu. Narodna skupština Republike Srbije na sjednici održanoj 8. studenog 2016. donosi odluku o proglašenju ustava Republike Srbije. ${ }^{4}$ Prema ustavu, Srbija je svjetovna država u kojoj je glavni grad Beograd, službeni jezik je srpski jezik koji se piše ćiriličnim pismom. Prema Zakonu o upotrebi grba, zastave i himne Republike Srbije ${ }^{5}$ državna zastava je horizontalna trobojka sa jednakim poljima, koja odozgo prema dolje su u bojama crvenoj, plavoj i bijeloj. Na zastavi se nalazi grb, koji je još bio utvrđen Zakonom o grbu Kraljevine Srbije 1882. godine. Na njemu je crveni štit na kojem je dvoglavi srebrni orao koji na grudima ima crveni štit na kojem je prikazan srebrni križ, koji među krakovima ima po jednu ocilo.

Poslije raspada komunizma srpsko se društvo nije reformiralo niti je prihvatilo mogućnost demokratske promjene. Prema riječima povjesničarke Dubravke Stojanović, društvo je ušlo u novi ciklus ratova „očigledno nemoćno da na izazov postkomunističke tranzicije odgovori snažnim reformskim zamahom, ono je otvorilo sebi put u novo, dotada nezabeleženo ratno i političko nasilje. U tu novu spiralu zla Srbiju će uvesti njen skoro plebiscitarno izabrani vođa Slobodan Milošević, koji je za svoju politiku dobio skoro nepodeljenu podršku elite. Umesto demokratizacije društva, srpska elita je izabrala rat za prekomponovanje bivše jugoslovenske

\footnotetext{
${ }^{3}$ Ustavna odluka Sabora Republike Hrvatske o suverenosti i samostalnosti Republike Hrvatske (25. lipnja 1991.), www.sabor.hr

${ }^{4}$ Ustav Republike Srbije, www.parlament.gov.rs

${ }^{5}$ Zakon o upotrebi grba, zastave i himne Republike Srbije, http://www.srbija.gov.rs/pages/article.php?id=12084
} 
države“(Stojanović 2010: 54). Sustav koji nastaje od početka devedesetih i traje do konačnog pada Miloševića s vlasti, u kojem je građanima dozvoljeno sve osim da ugroze vlast, Stojanović naziva postmodernim totalitarizmom. Vladajuća stranka imala je kontrolu nad svim organima vlasti, uključujući vojsku, policiju, privredu, sudstvo i sve financijske tokove (Stojanović 2010: 55). Rat u okruženju i sankcije koje je Srbiji nametnula međunarodna zajednica doveli su do porasta kriminala i stvaranja ratne financijske elite. Kriminalizirana država i društvo ostaju u nasljeđe demokratskim strankama koje formiraju vlast nakon 2000. godine sa kojim se one ne uspijevaju izboriti, ,a posle ubistva najubeđenijeg nosioca reformi Zorana Đinđića, srpsko društvo i politika ostali su dezorijentisani, bez jasne slike budućnosti, zapreteni nespremnošću da se suoče sa prošlošću i da se, na osnovu jasnog društvenog konsenzusa, pokrenu ka promenama i evropskim integracijama“" (Stojanović 2010: 56).

Srbija je trenutno u procesima pregovora o pristupanju Europskoj uniji. Zahtjev za članstvo podnijela je još 2009. godine, a status kandidata dobila je tri godine kasnije. Početkom 2014. godine i formalno su započeli pregovori sa Europskom unijom. ${ }^{6}$

\section{Položaj žena od 1965. do 2011. godine}

\section{Zakonski okvir}

Prvi dokument kojim je u poslijeratnom periodu bila garantirana pravna ravnopravnost žene jest Ustav FNRJ iz 1946. godine, prema kojem je žena po prvi put potpuno izjednačena sa muškarcem u svim oblastima života (Gudac-Dodić 2006: 34). To je značilo da je žena mogla raditi za istu plaću kao muškarac, obrazovati se, glasati, biti izjednačena u braku s muškarcem itd., što je velik pomak i promjena u odnosu na Srpski građanski zakonik iz 1884. godine, koji je bio na snazi sve do 1946. godine i ženu stavljao u vrlo neravnopravan i potlačen položaj:

\footnotetext{
[...] udata žena u pogledu svoje opšte poslovne sposobnosti bila je izjednačena s maloletnicima, $s$ umobolnim licima, raspikućama, propalicama. Njen pravni položaj bio je takav da je u potpunosti bila potčinjena mužu. U slučaju razvoda muška deca iznad četvrte godine, odnosno devojčice iznad sedme, uvek su pripadala ocu itd. Istraživanje i dokazivanje očinstva vanbračnog deteta bilo je zabranjeno, izuzev u slučajevima odvođenja ili silovanja.(Gudac - Dodić 2006: 36)
}

Bitno je napomenuti i da je spomenutom Ustavu FNRJ prethodila Narodno oslobodilačka borba u kojoj su od samog početka sudjelovale žene kao bolničarke, liječnice, borkinje i za svoja

\footnotetext{
${ }^{6} \mathrm{http}: / /$ www.seio.gov.rs/pocetna.102.html
} 
zalaganja dobivale određene činove, pa je već 1942. činove dobilo sedamnaest žena među kojima je bilo i potpukovnica (Božinović 1996: 141). Za vrijeme Drugog svjetskog rata više od 100000 žena borilo se ravnopravno s muškarcima, a nakon završetka rata za narodne heroje proglašeno ih je 90 (Gudac-Dodić 2006: 34-35).

Kako je Ustav propisivao samo zakonski okvir, specifična prava žena bila su posebno razrađena u Osnovnom zakonu o braku iz 1946. Ovaj dokument razrađuje osnovna načela građanskog braka, koji je obavezan i jedini punovažan, a u njemu je žena izjednačena s muškarcem po pitanju prava, roditeljskih obaveza, odnosa prema djeci itd.

Božinović navodi kako su se svi kongresi SKJ (Saveza komunista Jugoslavije) bavili problemima žena u društvu, ali samo u Titovim izlaganjima, dok se u diskusijama na ta pitanja ne osvrću drugi muškarci, a tek rijetko pokoja žena.

U rezolucijama se svi zadaci u pogledu promena društvene situacije žena ne postavljaju ženama, već Savezu komunista. Ti zadaci uglavnom su poznati i stereotipni: zapošljavanje i stručno obrazovanje žena, njihov izbor na rukovodeće funkcije, razvoj dečjih ustanova, škola i društvenih službi za pomoć porodici i domaćinstvu na principima solidarnosti. (Božinović 1996: 197)

\section{Obrazovanje}

Kada je riječ o obrazovanju i stručnom osposobljavanju, velik problem predstavljala je opća nepismenost, budući da je Jugoslavija imala gotovo najviše nepismenog stanovništva u odnosu na druge Evropske zemlje. Broj nepismenih žena deset godina prije početka Drugog svjetskog rata iznosio je 56,4 \%, a već 1948. bio je znatno smanjen - na 34,4\%. Poslijeratna vlast sistemski je radila na opismenjavanju stanovništva te je od 1946. do 1950. godine opismenjeno skoro dva miliona ljudi (Božinović 1996: 20). Školovanje ženske djece također je bilo u porastu, tako da već školske godine 1987./'88. nije bilo neravnomjernosti u zastupljenosti dječaka i djevojčica u osnovnoškolskom obrazovanju (Božinović 1996: 231).

Krajem tridesetih godina dvadesetog stoljeća najviše učenica upisivalo je ekonomske, umjetničke i učiteljske srednje škole, a u odnosu na ukupnu učeničku populaciju bile su zastupljene sa 43,5\%. Taj broj se za 5,7 puta uvećava pedesetih godina, a djevojke se školuju u svim školama uključujući i građevinske i rudarske. Zanimljivo je napomenuti i da tridesetih 
godina srednje medicinske škole upisuju isključivo djevojke. Školske godine 1950./1951. mijenja se i zainteresiranost za stručna usmjerenja, pa je tako najviše upisanih djevojaka u učiteljskim školama, zatim u ekonomskim, medicinskim i na kraju umjetničkim. Krajem osamdesetih najviše je učenica u ekonomskim školama, pravno-birotehničkim i ostalima koje daju opće obrazovanje (Božinović 1996: 232).

Studiranje na filozofskim fakultetima bilo je jednako popularno i tridesetih i pedesetih godina prošloga stoljeća, ali je broj studentica uvećan za pet puta, na medicinskim fakultetima za čak osam puta, a na ekonomiji za gotovo jedanaest puta.

Podaci pokazuju da je sve više žena koje su se specijalizovale, magistrirale ili doktorirale. Od 1962.

godine, kada su ta zvanja ustanovljena, do 1990. zvanje specijalista i magistra nauke steklo je ukupno 28.695 muškaraca i 11.450 žena što čini $28,5 \%$ u odnosu na ukupan broje specijalista i magistara. (Božinović 1996: 233)

U školskoj godini 1993./1994. broj upisanih studenata na fakultete počinje opadati, ali istovremeno raste broj upisanih studentica, pa ih je tako u navedenoj školskoj godini 54,9\% (Božinović 1996: 234).

Ovaj trend nastavlja se i narednh godina. Prema posljednjim podacima Republičkog zavoda za statistiku Republike Srbije, koji se odnose na 2014. godinu, u Srbiji je diplomiralo 8012 studenata i 10440 studentica. Kada je riječ o visokim zvanjima, broj doktora znanosti u istoj godini iznosi 1089, od čega su 515 muškarci, a 574 žene.

\section{Zapošljavanje žena}

Pravo žene na rad i ostvarivanje ekonomske nezavisnosti jedno je od ključnih pitanja emancipacije žena u socijalizmu. Antifašistička fronta žena (AFŽ) posebno je propagirala zapošljavanje žene, budući da upravo zaposlenost ženi omogućava potpunu ravnopravnost. AFŽ se aktivno bavila organizacijom tečajeva za nepismene, ali i programima koji su se odnosili na zdravu prehranu, brigu o djeci, higijenu itd. (Božinović 1996: 158). U poslijeratnom periodu obnove zemlje žene su se aktivno uključivale u sve poslove, i taj je vid afirmacije bio snažno potican u tada najčitanijem dnevnom listu Politika. Gudac-Dodić (2006) navodi kako dnevni list Politika objavljuje članke u kojima prikazuju ženu koja je heroj rada, udarnica i uzor drugima zbog svog zalaganja: 
Bez obzira na to da li je pisano o ženama koje su bile zaposlene u tekstilnim fabrikama, na razbojima, u poljoprivredi ili nekoj drugoj privrednoj grani, u tim tekstovima su isticane žene koje su svojim vanrednim zalaganjem i upornošću, prebacivale predviđene norme. O njima je pisano veoma afirmativno, prikazivan je njihov život i afirmisan je rad kao jedna od vrhovnih vrednosti. (GudacDodić 2006: 60)

Samo dvije godine od završetka Drugog svjetskog rata u cijeloj Jugoslaviji zaposleno je 337 000 žena, a kada se usporede podaci o zaposlenosti žena iz 1945. i 1949. godine, broj se uvećao za četiri puta (ibid. 2006: 62). Pedesetih godina trend se nastavlja, tako da je veći broj zaposlenih žena u odnosu na broj muškaraca, i ova prednost kontinuirano traje sve do devedesetih godina (ibid. 67). Ipak, dokumentacija ženskih organizacija svjedoči o teškoćama žena da zadrže svoja radna mjesta jer bi u okolnostima smanjivanja broja zaposlenih poduzeća masovno otpuštala upravo žene (ibid. 64) Istraživanja lista Politika iz pedesetih godina pokazuju da se tretman žene počinje mijenjati, uvodi se posebna ženska rubrika koja ženi udarnici vraća ženstvenost jačajući kult ljepote i ističući modne trendove, koji su neposredno nakon rata bili potpuno zanemareni (ibid. 66).

Devedesete godine donose raspad SFRJ, građanski rat i ekonomsku krizu, koja je u Srbiji dodatno pojačana sankcijama OUN, a potom i NATO bombardiranjem 1999. godine. Samim tim od devedesetih godina naovamo ukupan broj zaposlenih drastično opada, pa se tako od 1993. do 2000. broj svih zaposlenih umanjio za 17,8 \%. (ibid. 67-68). Kada se promatra struktura nezaposlenih žena, uočljive su promjene šezdesetih, sedamdesetih i devedesetih godina. Sredinom šezdesetih na području SR Jugoslavije većinu nezaposlenih žena čine one bez ikakvih kvalifikacija, sedamdesetih se povećava broj nezaposlenih žena sa srednjom i visokom stručnom spremom, a osamdesetih je više obrazovanih nezaposlenih žena nego onih potpuno nekvalificiranih. Devedesetih je pak dosegnut vrhunac jer je među nezaposlenim ženama najviše onih sa srednjom, višom i visokom stručnom spremom. U periodu od 1993. do 2000. godine uočava se trend bržeg zapošljavanja žena s višim i visokim obrazovanjem, mada u pravilu žene dulje čekaju na zaposlenje u odnosu na muškarce. U prosjeku, najveći broj žena na posao čeka do tri godine (ibid. 71-72). Kada je riječ o zastupljenosti žena na rukovodećim pozicijama, ne uočava se veći napredak u odnosu na socijalistički period; 1987. godine u Jugoslaviji žene čine $6,43 \%$ direktorskih pozicija i drugih rukovodećih tijela, a početkom 21 . stoljeća u SR Jugoslaviji žene participiraju sa samo 7\% na spomenutim mjestima (Gudac-Dodić 2006: 74). Devedesete godine u Srbiji su bile obilježene velikom nezaposlenošću, padom proizvodnje, procvatom ,sive ekonomije“, niskim životnim standardom i istovremeno buđenjem patrijarhalne svijesti, ,što se upečatljivo manifestovalo na primeru smanjenog učešća 
žena u donošenju političkih odluka, usled njihovog minornog prisustva u Skupštini Srbije posle prvih višepartijskih izbora. Žene su bile ponovo usmerene da svoj život i sopstvenu realizaciju vide prvenstveno kroz porodicu i decu i to na način u kojem preuzimaju na sebe najveći deo odgovornosti za nju.“(Gudac-Dodić 2006: 127).

\section{Povijesne ličnosti izvan vremena 1965-2011.}

\section{Sveti Sava}

Sveti Sava (oko 1175-1235) začetnik je samostalne srpske književnosti, prvi arhiepiskop samostalne srpske crkve $\mathrm{i}$ istaknuta politička ličnost srednjovjekovne Srbije. Rođen je kao Rastko Nemanjić, najmlađi sin Stefana Nemanje - rodonačelnika vladarske loze Nemanjića i kao mladić napustio je očev dvor i otišao na Svetu Goru gdje se zamonašio (Deretić 1991: 89). Njegovom zaslugom i zalaganjem osnovan je manastir Hilandar na Svetoj Gori kao potpuno samoupravni i nezavisni manastir, što je potvrdio tadašnji bizantski car Aleksij II Anđel u Carigradu 1198. godine davši Savi zlatopečatni stilij, a poslije i hrisovulju (Bogdanović 1986: 10). Sava se smatra tvorcem prve biografije kao žanra u srednjovjekovnoj srpskoj književnosti (,Žitije Svetog Simeona“ - život njegovog oca Stefana Nemanje, koji se zamonašio i uzeo ime Simeon, kasnije je proglašen svecem). Savin književni rad razvija se u tri pravca: biografskom, liturgijskom i pravnom, budući je pisao liturgijske tekstove, ali i pravne dokumente koji su regulirali manastirski život (Karejski, Hilandarski i Studenički tipik), od kojih je najznačajniji Nomokanon ili Krmčija svojevrsna kodifikacija bizantskog prava (Deretić 1983: 71). Bogdanović (1986: 12) navodi kako tim dokumentom Srbija već početkom 13. stoljeća dobiva pravni poredak i postaje pravna država: „Krmčija je predstavljala kapitalni izbor i spomenik prava: u srednjovekovnoj srpskoj državi, to je izvor prvog reda kao „božansko pravo“; tek posle toga dolazi, na primer, zakonodavstvo srpskih vladara uključujući i Zakonik cara Stefana Dušana“ (Bogdanović 1986: 18).

Smatra se da je za vrijeme Savinog boravka na Svetoj Gori provedena izmjena pravopisa, kojom je tadašnji način pisanja staroslavenskog prilagođen srpskom izgovoru. Pavle Ivić navodi kako postoji dosta razloga zbog kojih se može smatrati da je upravo Sava zaslužan za tu reformu:

Taj moćni državnik i crkveni poglavar bio je i rodonačelnik jedne književnosti; njegovoj pažnji svakako nije moglo izmaći pitanje načina pisanja jezikom te književnosti. Uostalom, i već pomenuto 
normiranje samog tog jezika, koje spada u istu epohu, ne bi moglo proći mimo Savine volje. (Ivić 1998: 39)

Kao aktivni sudionik političkog života srednjovjekovne Srbije, Sava je odlazio stranim vladarima u diplomatske misije, obilazio Srbiju, sastajući se i sa vlastelom, ali i s prostim narodom (Deretić 1980: 71). Deretić ocjenjuje da Sava kao pisac nije u većoj mjeri utjecao na tokove književnosti, bio je popularniji kao junak žitija, nego kao pisac (Deretić 1980: 73). Umro je 1235. ili 1236. na povratku sa svog drugog putovanja u Svetu zemlju, u Trnovu u Bugarskoj, gdje je prvobitno i bio sahranjen. Kasnije je prebačen u manastir Mileševa, gdje nastaje kult Svetog Save, koji traje kroz cijeli srednji vijek, održavajući se jakim i u doba turske vladavine, unatoč tome što su Turci 1594. u Beogradu spalili Savine mošti (Bogdanović 1986: 13).

\section{Vuk Karadžić}

Vuk Stefanović Karadžić (1787-1864) najpoznatiji je kao reformator srpske ćirilice i sakupljač narodnih pjesama te drugih oblika narodnog stvaralaštva. Karadžić je do kraja života sakupljao i bilježio narodno usmeno stvaralaštvo, a za taj je dio svog rada često nazivao najmilijim. Sakupljene pjesme, koje objavljuje u četiri knjige, obuhvaćaju 793 lirske i 252 epske pjesme. Objavio je i knjigu narodnih poslovica i pripovijedaka, kao i narodne zagonetke (Deretić, 1991: 185).

Prema riječima Jovana Deretića (1983: 253) cjelokupno Karadžićevo stvaralaštvo može se odrediti pojmovima narod i narodno, ali da bi se razumjelo zašto Karadžić reformira azbuku i uvodi narodni jezik kao književni, neophodno je ukratko se dotaći pitanja srpskog književnog jezika i pitanja pisma.

Naime, prvi književni jezik kod Srba bio je srpskoslavenski - srpska redakcija staroslavenskog, drugi je bio ruskoslavenski - ruska redakcija staroslavenskog, a treći slavenosrpski, koji je nastao ponarodnjavanjem ruskoslavenskog jezika. Ruskoslavenski ulazi u upotrebu pod specifičnim povijesnim okolnostima u okvirima Haburške Monarhije, kada Srbi vide opasnost od unijaćenja i pomoć traže od Rusije.

Tako je kod Srba umjesto srpskoslavenskog jezika uveden novi jezik - ruskoslavenski - koji je, kakav paradoks, u matici, nakon velike kulturne reforme Petra Velikog, od polovine 18. vijeka funkcionisao samo kao liturgijski jezik. (Okuka 2010: 46) 
Slavenosrpski nastaje iz potrebe i želje srpskih pisaca da pišu jezikom koji će biti razumljiv široj čitalačkoj publici u doba prosvjetiteljstva i racionalizma, u 18. stoljeću. Krajem 18. stoljeća i početkom 19. nameće se pitanje izbora srpskog književnog jezika, a narodni jezik kao njegova osnovica postaje sve izglednije rješenje.

Kada je riječ o samom pismu, ćirilica kojom su Srbi pisali početkom 19. stoljeća imala je više grafema nego što je postojalo glasova u narodnom jeziku, jer je obitavalo više tipova ćirilice $\mathrm{i}$ „ta je azbuka, dakle udruživala rđave strane suvišnosti i nedovoljnosti, uz nekoliko drugih vidova neracionalnosti. Uz to je i pravopis bio nesređen i vrlo kolebljiv. Sve je to činilo čitanje napornim i ne uvek pouzdanim, a proces opisemenjavanja tegobnim i dugim“ (Ivić 1998: 173). S obzirom na navedene teškoće, već krajem 18. i početkom 19. stoljeća srpski pisci počinju spontano izostavljati slova koja nisu imala glasovne vrijednosti, a za glasove koji nisu imali grafijsko rješenje koriste ustaljene kombinacije slova, tako da se već na taj način izražava potreba za reformom azbuke (ibid.).

Prvu temeljitu reformu donosi Sava Mrkalj u svojoj studiji Salo debeloga jera libo azbukoprotres, koja je obavljena 1810. godine u Budimu. Mrkalj je iz crkvene ćirilice izostavio ukupno 16 nepotrebnih grafema, glasove $l j, n j, c ́$ i $d$ pisao je u kombinacijama $l, n, t$ i $d$ s mekim poluglasnikom, $j$ je označavao deseteračkim $i$, a slova za glas $d \check{z}$ nije imao. Na posljednjim stranicama knjige, pokazao je i praktičnu primjenu svoje azbuke, koja bila izgrađena na principu fonološke grafije (Okuka 2010: 83-84).

Mrkalj nije osmislio nova, jedinstvena slova koja bi zamijenila njegove digrame, čime bi azbuka bila savršena u fonetskom smislu, već je taj posao ostavio svojim nasljednicima, tj. Vuku Karadžiću, koji već 1814. u Pismenici koristi nova slova, a reformu završava četiri godine kasnije, 1818. u Srpskom rječniku. Tada je u potpunosti poštovano pravilo jedno slovo - jedan glas i srpska ćirilica je dobila svoj današnji izgled, dakle $l j, n j, c ́$ i $d$ se pišu kao $\_, \curvearrowleft, \hbar, \hbar$, slovo $d \check{z}$ je preuzeto iz starijih tekstova ( $\mu$ ), a $j$ iz latinice (Okuka 2010: 87-88).

Vuk Karadžić rođen je u Tršiću kod Loznice u obitelji koja je u Srbiju doselila iz Crne Gore, sačuvavši svoj istočno-hercegovački dijalekt i ijekavski izgovor. Njegovo školovanje nije bilo ni kontinuirano ni sistematično. Započelo je u manastiru Tronoša, odakle je Karadžić porijeklom. U nastojanju da uči stigao je do Sremskih Karlovaca, Petrinje i Beograda (Ivić 1998: 175-176). Nakon propasti Prvog srpskog ustanka stanovništvo je masovno bježalo preko Dunava, sklanjajući se od osvete Turaka. Karadžić je tako stigao do Beča, gdje piše članak za Novine srpske o propasti ustanka i upoznaje Jerneja Kopitara, tadašnjeg austrijskog cenzora za 
sve knjige, koje su u Beču izlazile na slavenskim jezicima. Poznanstvo se pretvorilo u čvrsto prijateljstvo i plodonosnu suradnju, jer Karadžić na Kopitarov poticaj sastavlja Pismenicu (srpska gramatika) (Milanović 2010: 116) i Pjesnaricu (zbirka od sto lirskih i osam epskih narodnih pjesama). Pjesnaricu piše Mrkaljevom reformiranom azbukom, a u predgovoru navodi načelo „Piši kao što govoriš, a čitaj kao što je napisano“, čije se autorstvo kasnije kontinuirano dovodilo u vezu s Karadžićem, mada pripada njemačkom filologu Johanu Adelungu (Ivić 1998: 180).

Jedan od velikih izazova Karadžiću je predstavljao prijevod Novog zavjeta na narodni jezik, koji je uspio izdati tek 1847. zbog velikih protivljenja Crkve. Karadžić je htio pokazati „da je njegov književni jezik dovoljno bogat i gibak da bi mogao iskazati složeni, često apstraktni sadržaj Biblije, pun značenjskih preliva osetljivih s teološkog gledišta“ (Ivić 1998: 217). Na kraju se ipak pokazalo da je leksikon narodnog jezika nepotpun, pa je Vuk sam stvarao nove riječi ili je uzimao riječi slavenskog porijekla koje je posrbljavao (Ivić 1998: 217). Objavljivanje Novog zavjeta na narodnom jeziku izazvalo je dosta polemika, ali je 1847. godina već bila godina neformalne pobjede Karadžićeve reforme, jer nakon Novog zavjeta iz štampe izlazi Rat za srpski jezik i pravopis Đure Daničića, Gorski vijenac Petra II Petrovića Njegoša, Pesme Branka Radičevića (Milanović 2010: 125).

U to vrijeme u Srbiji je još na snazi bila zabrana unošenja u zemlju knjiga štampanih Vukovom ćirilicom, koju je uspostavio Miloš Obrenović još 1832. i obnavljao je nekoliko puta. Čak je 1850. godine izdan poseban dekret kojim se zabranjuje uvoz Karadžićevog prijevoda Novog Zavjeta u Srbiju.

\footnotetext{
Srpska vlada je tek 1860. godine donela zakon kojim se dozvoljava upotreba Vukove ćirilice u svim izdanjima, osim u zvaničnim i školskim knjigama, i to je jedna od retkih Vukovih zvaničnih pobeda koje je doživeo. Poslednja zvanična zabrana skinuta je 1868. godine, četiri godine posle Vukove smrti. (Milanović 2010: 132)
}

Ivić zaključuje kako je Karadžićevom pobjedom dovršeno ponarodnjavanje srpskog književnog jezika, ali da to nikako ne znači da bi bez pojave Karadžića taj jezik ostao ruskoslavenski, jer je već sa Dositejem Obradovićem počelo pisanje na narodnom jeziku.

Karadžićeva veličina je u tome što je, kao i toliki drugi veliki ljudi, uspešno izvršio zadatak koji je postavila historija. On je to, uostalom, učinio temeljitije i brže nego što bi mogao neko drugi na njegovom mestu. (Ivić 1998: 220) 


\section{SOCIJALNO SEMIOTIČKI PRISTUP ANALIZI}

\section{Analiza slikovnog sadržaja}

\subsection{Teorijsko-metodološki okvir}

Srpski bukvari nastali u vremenu od 1965. do 2011. godine bit će analizirani kroz socijalno semiotički pristup. Termin socijalna semiotika (engl. social-semiotics) u lingvistiku uvodi Michael Halliday u djelu Language as social semiotic: The Social Interpretation of Language and Meaning iz 1978., u kojem je jezik sustav mogućnosti i značenjskog potencijala. Sintagma „jezik kao socijalna semiotika“ pritom podrazumijeva interpretaciju jezika u društvenokulturnom kontekstu u kojem se sama kultura može interpretirati u semiotičkom smislu (Halliday 1978: 2). Nešto više od decenije kasnije Bob Hodge i Gunther Kress u zajedničkom ostvarenju Social Semiotics (1988) razvijaju detaljniji semiotički okvir, da bi Kress i van Leeuwen sredinom devedesetih formirali gramatiku vizualnog dizajna stavivši akcent na vizualno i pozabavivši se multimodalnošću, o čemu će u ovom poglavlju biti više riječi.

U studiji Introducing Social Semiotics Van Leeuwen (2005: 3) definira tri osnovna zadatka društvenog semiologa: (1) prikupljanje i dokumentiranje semiotičkih resursa; (2) proučavanje njihove uporabe u specifičnim povijesnim i kulturnim kontekstima; (3) davanje doprinosa otkrivanju i razvoju novih semioloških resursa. Teoriju socijalne semiotike, koja se ovdje primjenjuje, postavljaju Kress i Van Leeuwen (2006) u svojoj gramatici vizualnog dizajna. Autori različite vizualne resurse i ustaljene kompozicijske strukture sagledavaju kao ustaljene obrasce koji se koriste da bi proizveli značenje u zapadnoj kulturi. Njihova je pretpostavka da dominantan vizualni jezik postoji i da ga kontroliraju globalna kultura i masovni mediji (ibid. 4). Oni vizualne reprezentacije vide kao društveno i kulturno utemeljen proces u kojem se znacima izražava značenje, kojim pak upravljaju interesi stvaraoca znaka. Vizualne strukture ne produciraju strukture tzv. realnosti, one proizvode slike realnosti koje su povezane s interesima društvenih institucija u okviru u kojem i nastaju (ibid. 47). Autori ne samo da izdvajaju reprezentacijske obrasce nego utvrđuju i načine na koje dolazi do interakcije između stvaraoca znaka i gledaoca.

Izvor razmišljanja o općenitim društvenim i semiotičkim procesima autori pronalaze kod Michaela Hallidaya, utemeljitelja funkcionalne gramatike, koja težište stavlja na funckionalnost jezičnog sustava. U ovom poglavlju neće biti detaljno prikazana sistemska funkcionalna 
lingvistika kao teorija, nego će se dati osvrt na elemente koji čine osnovu za stvaranje „vizualne gramatike“. Kress i Van Leeuwen posebno uzimaju u obzir njegovu podjelu na tri metafunkcije jezika, koja je za njih polazna točka u promišljanju svih modova/modaliteta reprezentacije (2006: 20). Hallidayevu školu još se naziva i sistemskom funkcionalnom gramatikom prema djelu An introducition to Functional Grammar, koju prvi put objavljuje 1985. godine. Gramatika je za njega istovremeno i društvena i semiotička, pa tako primjere gramatičkih opisa daje kroz jezičnu upotrebu (Halliday 1985, 1994). Razlikuje tri metafunkcije jezika: (1) Ideacijsku: odnosi se na način na koji se ljudsko iskustvo pretače u značenja (2) Interpersonalnu: odnosi se na jezične resurse koji pomažu oblikovati društvene odnose, sam naziv sugerira da je ona i interaktivna i personalna i (3) Tekstualnu: objedinjuje prethodne dvije metafunkcije odnoseći se na načine kojima se gradi tekst. Halliday inzistira na terminu metafunkcija jer sistemska analiza pokazuje da je funkcionalnost suštinska odlika jezika. „Termin metafunkcija je usvojen kako bi sugerirao da je funkcija sastavna komponenta u sklopu cjelokupne teorije“ (Halliday 2004: 29). Spomenute metafunkcije Kress i Van Leeuwen izdvajaju kao primjenjive na sve semiotičke načine (,modove“) (2006: 42) i njihov fokus je usmjeren na realizaciju metafunkcija u vizualnom načinu (ibid. 44). Semiotički način termin je koji Kress i Van Leeuwen dosljedno koriste, može se reći da ti načini oblikuju sastavne karakteristike medija, povijesti i vrijednosti nekog društva. Upotreba vizualnog načina nije ista danas, kao što nije bila ni prije 50 godina u zapadnom društvu. Nije ista ni u različitim društvima, kao što nije ista ni u različitim društvenim grupama ili institucijama (ibid 35). Autori pažnju posvećuju i funkcionalnoj semiotičkoj teoriji kod Hallidaya, koja koristi termine akter, cilj, recipient, transakcija u smislu odnosa (nešto što akter radi cilju), kao i transakcijske, klasifikcijske i analitičke strukture (ibid. 50). Kasnije će u ovom poglavlju biti detaljno prikazana njihova klasifikacija vizualnih reprezentacija.

Multimodalnost je široko zastupljen termin u teoriji socijalne semiotike, a odnosi se na kombinaciju različitih semiotičkih modova, npr. jezika i muzike, u komunikacijskoj tvorevini ili događaju (Van Leeuwen 2005: 28). Kress i Van Leewen se prema vizualnome odnose jednako posvećeno kao i prema jezičnom elementu odbacujući pritom Barthesov argument da je značenje slike uvijek u vezi s verbalnim i da na neki način ovisi o njemu. Za njih je vizualna komponenta teksta nezavisno organizirana poruka koja je povezana sa verbalnim dijelom, ali neovisna od njega i obratno (Kress i Van Leeuwen 2006: 17). Kod multimodalne upotrebe slikovnog i verbalnog elementa slika može nositi jedan niz značenja, a verbalna poruka drugi, 
npr. u reklami verbalni tekst može biti neseksistički, dok slika sadrži seksualne stereotipe (ibid 20).

Vizualna gramatika termin je prisutan već u samom naslovu djela - Grammar of Visual Design, ali treba reći da ona nije univerzalna. Nju se može promatrati kao inventar elemenata i pravila koji je u podlozi nekog oblika vizualne komunikacije, koji je pak kulturno uvjetovan. Njihov okvir odnosi se na zapadno društvo (ibid 1).

Engleske riječi visual i verbal termini su koje autori koriste za razlikovanje slikovnih i jezičnih elemenata teksta (ibid. 30), iz čega je vidljivo da je i sam tekst za njih širi pojam. U ovom radu bit će preuzeta njihova terminologija i u skladu s tim će se u analizi posebno pristupiti slikovnim i jezičnim sadržajima bukvara. Dalje će biti prikazano na koji način autori klasificiraju vizualne strukture, ali će se razraditi samo dio metodologije koja se ovdje, uz određene adaptacije, koristi za analizu bukvara. Na ovom mjestu treba naglasiti i da se analiza bukvara neće baviti odnosom slikovnog i jezičnog sadržaja. Bukvar je jednostavna forma namijenjena opismenjavanju djece i kao takva ima ustaljen obrazac u kojem su slike dosljedno dane kao ilustracije slova koja se uče pisati ili tekstova za uvježbavanje čitanja.

\subsection{Narativne reprezentacije}

Prema teoriji Kressa i Van Leeuwena (2006) vizualne strukture dijele se na narativne i konceptualne reprezentacije. Narativne prezentiraju radnje, događaje, procese i imaju vektor (sudionici nešto čine, uglavnom rukama i/ili pomoćnim sredstvom), razlikuju vrstu aktivnosti, imaju glavne aktere, a akteri pak imaju ciljeve - ono na što je radnja usmjerena. Narativne reprezentacije razlikuju nekoliko tipova procesa: akcijski, reakcijski, govorni i mentalni.

1.3.1. Kod akcijskog procesa obavezan je akter koji je aktivni učesnik u radnji, od njega kreće vektor ili je sam dio vektora. Vektor je najčešće ruka u kombinaciji s nekim sredstvom. Ovdje se razlikuju tri vrste aktivnosti: (1) Jednosmjerna prijenosna aktivnost - vektor povezuje dva učesnika, a to su akter i cilj; (2) Dvosmjerna prijenosna aktivnost - vektor povezuje dva aktera i oni su tada interakteri; (3) Neprijenosna aktivnost - vektor polazi od aktera, ali nije usmjeren ni prema jednom drugom učesniku.

1.3.2. Reakcijski proces također može biti prijenosna i neprijenosna reakcija. Ovdje vektor nastaje linijom oka koja kreće od jednog učesnika i potom je usmjerena ili nije usmjerena na drugog učesnika. Aktivni učesnik u procesu reakcije čijim pogledom nastaje vektor zove se 
reakter. S druge strane, pasivni učesnik u prijenosnoj reakciji prema kojem je usmjeren pogled zove se pojava ilifenomen.

1.3.3. Mentalni proces radnja je u kojoj vektor čini „oblačić sa mislima“ kakav susrećemo u stripu, on povezuje dva učesnika, a oni su u ovom slučaju senser (od njega potječe oblačić) i pojava.

1.3.4. Verbalni proces ima vektor koji je zapravo strelica koja ide iz dijaloškog oblačića ili nečeg sličnog i povezuje govornika i govorni čin.

Kod narativnih reprezentacija postoje i sredstva, to su pomagala kojima se izvodi neka aktivnost, često imaju ulogu vektora. Osim aktera i ciljeva postoji i pratnja, a to je učesnik narativne reprezentacije koji nema vektorsku vezu sa ostalim učesnicima, a ne može se ni interpretirati kao simbolički dodatak.

1.4. Konceptualne reprezentacije za razliku od narativnih reprezentacija, koje imaju vektore i učesnike radnje, prezentiraju učesnike u smislu klase, strukture, značenja i sl. One su po prirodi su klasifikacijske i analitičke i nikad nemaju vektor. Mogu se podijeliti na tri velika procesa: (1) klasifikacijski, (2) analitički i (3) simbolički. U bukvarima su narativne reprezentacije puno zastupljenije, a kada su prisutne konceptualne reprezentacije, to su najčešće analitički procesi. Oni prave odnose među učesnicima tako što razlikuju dijelove od cjeline, pa imamo nosioca (predstavlja cjelinu) i posvojna svojstva, tj. dijelove (ibid. 87). U analizi će se oni nazivati upravo tako - cjelina i dijelovi.

\subsection{Interakcija}

Načinu prezentacije slikovnog sadržaja, kao i interakciji koju on ostvaruje sa svojim gledaocem, u slučaju bukvara namijenjenog sedmogodišnjem djetetu pristupa se analizom ostvarivanja slikovnog čina i pogleda, određivanjem veličine kadra i vrste kuta (ibid. 124-143). Naime, direktan pogled u sebi sadrži zahtjev, dok pogled koji nije direktan predstavlja ponudu. Kada je riječ o kadriranju, što je plan krupniji, to intenzivnije uključuje gledaoca, dok kod širokog postoji nevidljiva barijera između promatrača i prikazanog. Autori ne preuzimaju filmsku klasifikaciju kadra i plana jer je previše detaljna za njihove potrebe analize reklama, fotografija i ilustracija u udžbenicima, nego daju pojednostavljenu podjelu na blisku, srednju i dugačku udaljenost. Kod bliske udaljenosti objekt je prikazan tako da uključuje promatrača, u srednjoj je vidljiv u cijelosti, ali bez puno prostora oko sebe, a kod dugačke udaljenosti objekt se doima izloženim u izlogu. Za potrebe ove analize spomenuta klasifikacija adaptirana je na 
način da se srednja udaljenost odnosi na prikaz aktera do pasa ili koljena, što bi donekle odgovaralo američkom planu na filmu. Odabir horizontalnog i vertikalnog kuta također utječe na uključenost gledaoca. Horizontalni kut djelovanje je odnosa između prednje ravni stvaraoca slike i prednje ravni prezentiranih učesnika. S obzirom na to slika može imati prednju ili kosu točku gledanja, a odabir jedne od njih utječe na uključenost, tj. odvojenost promatrača od slike. Prednji kut šalje poruku „ovo što ovdje vidite je dio našeg svijeta, nešto u što smo uključeni““. Kosi kut daje distancu budući da se prikazano percipira kao nešto što pripada svijetu u koji kao promatrači nismo uključeni. Odabir vertikalnog kuta stvara odnos moći kod interaktivnih učesnika - stvaraoca slike i gledaoca. Autori razlikuju visoki i niski kut, kao i kut koji je na razini oka. Kod visokog kuta, moć nad prikazanim učesnikom ima gledalac, dok je kod niskog kuta obratno. U slučaju prikaza učesnika koji je dat na razini oka, odnos moći nije prisutan i interaktivni učesnici su jednaki.

\subsection{Modalnost}

Terminom modalnost autori dane teorije određuju pitanje pouzdanosti poruke: koliko je ona istinita, lažna, predstavlja li fikciju i sl. Teorija socijalne semiotike ne može tvrditi da je ustanovila da su neki prikazi apsolutno istiniti ili neistiniti. Ona može pokazati da li je prikazana stvar predstavljena kao istinita. Istina je pak nastala semiozom i kao takva istina neke društvene grupe proizlazi iz vjerovanja grupe. Visoka modalnost za njih je izjednačena sa naturalističnošću, jer slike koje imaju perspektivu, daju detalje, dobar prikaz boje, dubine i ostalo što npr. nudi standardna tehnologija fotografije u boji, imaju visoku modalnost. Kako se detalji, oštrina, boja, dubina i ostalo gube, tako modalnost pada.

\section{Analiza jezičnog sadržaja}

\subsection{Teorijsko-metodološki okvir}

Jezični sadržaji u bukvarima analizirat će se pomoću pristupa društvenih aktera i društvene aktivnosti koje, pored ostalog, Th. Van Leuween nudi kao nove alate kritičke analize diskursa u djelu Discourse and Practice (Van Leuween, 2008), uzimajući u obzir i perspektive iz antropologije, sociologije i filozofije. Kritička analiza diskursa, gledajući razvojno i konceptualno, spada u semiotički okvir budući da kao i socijalna semiotika polazi od sistemske funkcionalne lingvistike; obje ih zanima ispoljavanje moći, bave se vezom jezika i društva i nemaju strogo utvrđen metodološki obrazac koji bi bio općeprihvaćen način analize za sve istraživače. S obzirom na to da kritička analiza diskursa ima eklektičan pristup, gledano i 
teorijski i metodološki, istraživači nerijetko stvaraju vlastite metodologije ili adaptiraju postojeće prema svojim potrebama i cilju analize, što čini i Th. Van Leuween u gore spomenutom djelu.

Njegova temeljna postavka polazi od toga da postoji razlika između društvene prakse i njezinog predstavljanja u tekstu i kontekstu. Društvene prakse su društveno regulirani načini na koji se nešto radi i različite prakse su regulirane na različitim stupnjevima i na različite načine, npr. kroz tradiciju, utjecaj stručnjaka i sl. (ibid 6). One uključuju društvene aktere, njihove aktivnosti, reakcije na aktivnosti i druge elemente poput mjesta, vremena, odjeće, alata itd. Za razliku od drugih autora koji se bave kritičkom analizom diskursa, Van Leuween istražuje i multimodalne reprezentacije. Njegova metoda analize prvo rastavlja društvene prakse na sastavne dijelove, a potom utvrđuje kako ulaze u tekst i kako se transformiraju kroz upotrebu jezičnih ili nejezičnih sredstava. Transformacije mogu uključivati npr. supstituciju društvenih aktera, brisanje, asimilaciju upotrebom zbirne imenice itd. Autor izrađuje detaljne klasifikacije za reprezentacije društvenih aktera, društvene aktivnosti, bavi se kategorijom vremena, prostora, obrađuje vizualni prikaz aktera, aktere sa igračkama itd. Za potrebe ovog rada preuzeta je pojednostavljena klasifikacija društvenih aktera i društvene aktivnosti, na način primjenjiv u analizi bukvara, pa su oni određeni nominacijom (npr. nadimak ili puno ime i prezime, kategorizirani preko onoga što rade ili su identificirani tjelesno, relacijski - otac, majka, prijatelj itd.) (ibid. 2-51).

\subsection{Društveni akteri}

Reprezentacije uključuju ili isključuju društvene aktere kako bi se uklopile u svrhu i cilj koji je postavljen čitaocima (ibid 28) koristeći pritom različita jezična sredstva. U bukvarima su prisutni samo akteri koji su uključeni, te će oni biti prikazani pojednostavljenom klasifikacijom primjenjivom u analizi. U velikoj skupini aktera koji su uključeni u društvenu aktivnost izdvajaju se kategorije prisvajanja, određivanja i asimilacije. Kada je riječ o iskazivanju prisvajanja, ono se ostvaruje upotrebom posvojnih zamjenica ili pridjeva i nema svoje potkategorije. Društveni akter može se odrediti kategorizacijom i nominacijom. Određivanje je personalnog karaktera, za razliku od asimilacije u kojoj akteri gube svoje osobne karakteristike postajući sastavnim dijelom grupe. Kategorizacija se dijeli na funkcionalizaciju, koja kazuje što akteri rade (npr. fotograf, učitelj) i identifikaciju koja ih dalje raščlanjuje prema tome kojeg su spola, dobi, porijekla (klasifikacija), relacijski ih identificira (brat, sin i sl.) i tjelesno (mali, veliki). Akteri mogu biti određeni i nominacijom u koju ne spadaju samo osobna imena nego i titule. Nominacija može biti formalna - navodi se puno ime i prezime, poluformalna - samo 
ime i neformalna kada se navodi nadimak. Impersonalno se akter određuje asimilacijom, koja se jezično izražava zbirnom imenicom. (ibid. 40-46).

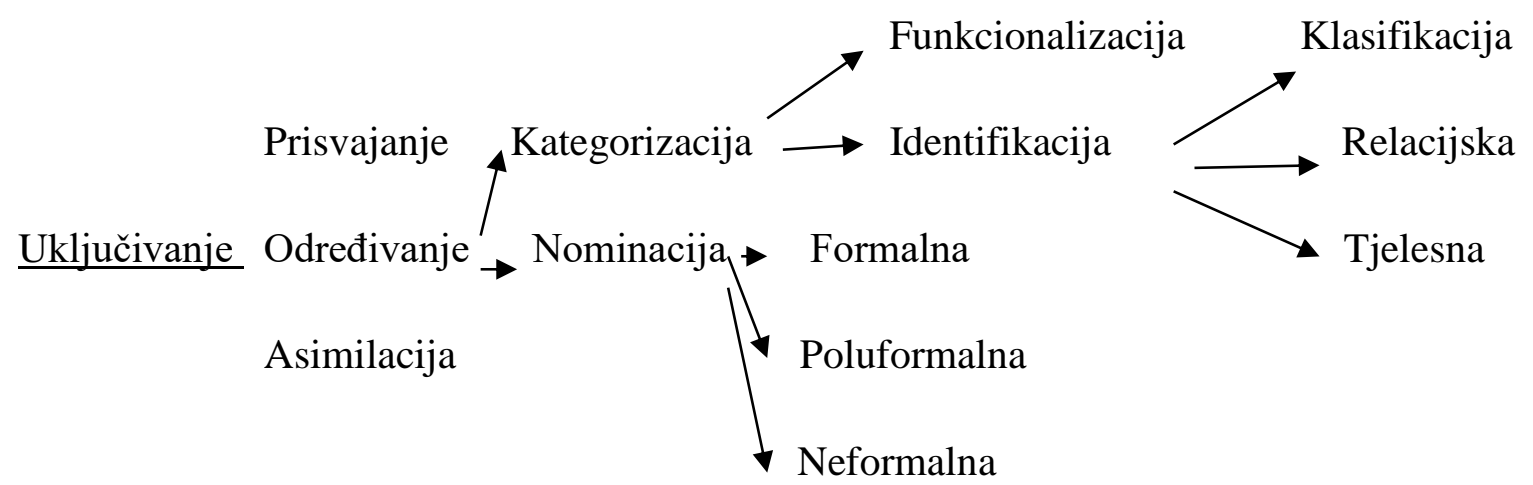

Dijagram 1. Društveni akteri

\subsection{Društvena aktivnost}

Provodeći analizu tekstova o imigrantima u Australiji, s ciljem da ustanovi na koji se način društvena aktivnost može predstaviti u engleskom jeziku, Van Leeuwen skicira neku vrstu sociološke gramatike prezentiranja društvenih aktivnosti. Daje sistemski inventar načina na koji se sve može iskazati aktivnost, pa su tako npr. reakcije Australijanaca prikazane aktivnim glagolima, dok su aktivnosti imigranata date nominalizacijama, apstrakcijama, metaforama i sl. Autor koristi kritičke sociosemantičke kategorije poput objektivizacije, naturalizacije i sl., ali ih dovodi u vezu s gramatičkim i retoričkim ostvarenjima (ibid. 56). Njegov model je u skraćenoj varijanti (Dijagram 2.) primjenjiv u analizi bukvara, gdje se nastoji otkriti u kakvoj vrsti društvene aktivnosti učestvuju djevojčice i dječaci, njihovi roditelji, djedovi i bake. Budući da je bukvar udžbenik za opismenjavanje, tekstovi su jednostavni, rečenice proste i bez skrivenih značenja, pa tako i klasifikacija društvenih aktivnosti sadrži samo dio koji se odnosi na aktivnost, dok npr. reakcija, objektivizacija, apstrakcija i dr. nema.

Aktivnost se može podijeliti na dvije velike skupine: (1) Materijalna: činiti nešto, ima makar potencijal prema nekom materijalnom cilju ili svrsi i (2) Semiotička: odnosi se na misaone procese i nema materijalni potencijal (ibid 59). Materijalne aktivnosti mogu biti prijelazne i neprijelazne. Kod prijelaznih postoje dva aktera od kojih jedan nešto čini drugome, drugi akter je cilj. Neprijelazne aktivnosti imaju samo jednog učesnika, koji je akter. Kod definicije cilja autor se poziva na Hallidaya (1985), za kojeg cilj mora biti stvar koja je fenomen našeg iskustva, a uključuje i naša unutarnja iskustva poput mašte, ili proces u smislu akcije, događaja, stanja i sl. Budući da je Hallidayev opis cilja dosta širok, Van Leeuwen ga svodi na razgraničenje između aktivnosti koje utječu na ljude i na stvari. S obzirom na ovakvu distinkciju aktivnosti 
mogu biti interaktivne ili instrumentalne. Kod interaktivnih cilj je čovjek i ovakve aktivnosti utječu na ljude. Instrumentalne aktivnosti za cilj mogu i ne moraju imati čovjeka, predstavljaju ljude kao moguće zamjene za objekte i u engleskom jeziku se iskazuju uporabom glagola use, trasnport, destroy, carry i sl. (ibid. 60-61). U analizi bukvara instrumentalna aktivnost će se odnositi samo na radnju koja za cilj nema čovjeka. Kod semiotičke prijelazne i neprijelazne aktivnosti pravila su ista kao i kod materijalnih kategorija.

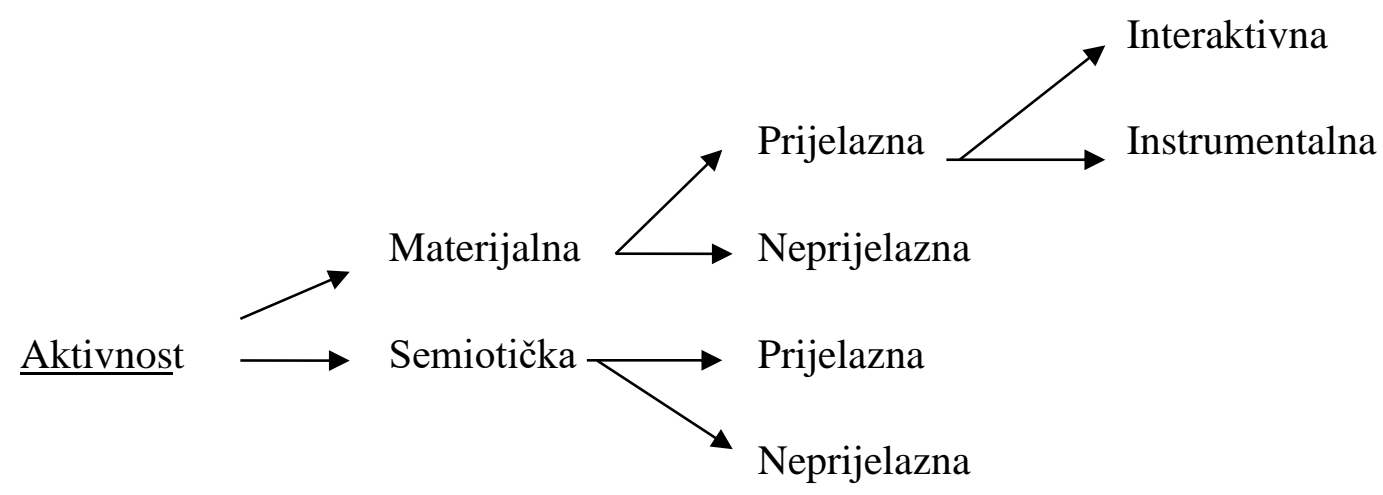

Dijagram 2. Društvena aktivnost

U analizi srpskih bukvara nastalih u vremenu od 1965. do 2011. godine, koja će primjenjivati metodologiju izloženu u ovom poglavlju, društveni akteri su dječaci i djevojčice, očevi i majke, djedovi i bake i povijesne ličnosti poput Josipa Broza Tita, Vuka Karadžića i Svetog Save. Naredno poglavlje prikazat će analizu etniciteta, koji se u bukvarima ostvaruje kroz dominaciju povijesnih osoba $\mathrm{i} / \mathrm{ili}$ prisutnost koncepta domovine, te rodne i međugeneracijske odnose kroz prikaz djevojčica i dječaka prvo zasebno, potom u interakciji, njihovih roditelja odnosno obiteljskih odnosa i veza koje u obiteljskom okruženju akteri međusobno uspostavljaju. Posljednja faza analize sagledat će aktere i njihove aktivnosti u dijakroniji i dobivene rezultate usporediti sa društvenim kontekstom. 
IV

\section{SOCIJALNO SEMIOTIČKA ANALIZA}

\section{Etnicitet}

Pojam etniciteta koji se ovdje koristi odnosi se na zajednicu koju povezuje kultura, jezik, tradicija, zajedničko porijeklo i drugi faktori (Hrvatsko antropološko nazivlje 2015:58-59), a etnicitet se definira kao ,globalni sustav klasifikacije različitosti ljudskih zajednica prema kulturnim obilježjima“. S obzirom na to da je bukvar vrlo jednostavan udžbenik kojim se dijete opismenjava, koncept etniciteta ovdje se svodi na dominantne povijesne ličnosti i elemente koji predstavljaju domovinu - npr. državne simbole, prikaze pionira, vojske, partizana i sl., koji se pak smjenjuju drugim elementima ili nestaju prateći društvene promjene. U ovome se poglavlju analiziraju prikazi povijesnih osoba i reprezentacije koncepta domovine u svakom od četiriju bukvara kroz posebnu obradu slikovnih i jezičnih sadržaja.

\subsection{Povijesne osobe}

\subsubsection{Analiza slikovnog sadržaja u bukvaru iz 1965. godine}

U bukvaru iz 1965. godine pojavljuje se slikovni prikaz samo jedne povijesne osobe, a to je tadašnji predsjednik SFRJ-a, Josip Broz Tito. Prisutan je na tri fotografije, što se možda na prvi pogled ne čini velikom zastupljenošću, ali kad se uzme u obzir njihovo pozicioniranje u bukvaru, njegova je pozicija dominantna. Naime, bukvar počinje službenim portretom Josipa Broza Tita, kojeg već na idućoj stranici prati njegova fotografija s učenicima. Spomenute dvije fotografije (slika 1 i slika 2) u ovom će poglavlju će biti zasebno analizirane i prezentirane.

U svoja tri pojavljivanja u bukvaru Tito je prisutan na dva portreta, koji su neprijelazne narativne reprezentacije (slika 1 i slika 2, str. 52), a na fotografiji sa djecom (slika 2) je prikazan kao akter. Kada je u ulozi aktera, vektori su ruke, a cilj su djeca koju dotiče objema rukama. Analizirajući ostvarivanje interakcije s promatračem, tj. korisnikom bukvara, prisutna je i ponuda, ali i zahtjev koji je praćen osmjehom, dok su kod odabira plana prisutne sve tri mogućnosti - srednja udaljenost (službeni portret), dugačka udaljenost (fotografija sa djecom) i bliska udaljenost (str. 52). U sva tri primjera odbran je prednji horizontalni kut koji šalje poruku „on je dio vašeg svijeta“ i vertikalni kut na razini oka kod kojeg nema iskazanog odnosa moći - „on je kao i ti“. Promatrajući modalnost, prvo što se uočava jest odabir fotografija za prikaz Tita, čime se postiže realističnost i uvjerljivost. Budući da fotografija u boji postaje 
široko rasprostranjena tek od sedamdesetih godina prošlog stoljeća (javljaju se u bukvaru iz 1974. godine), one su u crno-bijeloj tehnici. Nije slučajan odabir odjeće u kojoj se Tito pojavljuje na slikama. Na službenom portretu, ispod kojeg je potpisan kao predsjednik države, odjeven je u građansko odijelo s kravatom, a tako je i na zajedničkoj fotografiji s djecom. $\mathrm{Na}$ stranici 52 prikazan je u uniformi jer se njegova slika nalazi iznad teksta koji, između ostalog, govori o tome da je Tito ratovao. Dakle, prikazan je kao vojskovođa i ratnik.

Slika 1 nalazi se na samom početku bukvara, stoga je to ujedno i prvi sadržaj predstavljen učeniku prvog razreda osnovne škole, koji će narednih mjeseci savladavati čitanje i pisanje slova. Tito ovdje pogledom ne uspostavlja kontakt s korisnikom bukvara, jer je zagledan u daljinu (ponuda) ozbiljnog izraza lica, ali je istovremeno prikazan sa srednje udaljenosti, što ga približava korisniku bukvara. Upotrebom prednjeg horizontalnog kuta ovaj portret šalje poruku ,ja sam tvoj predsjednik“, ali ne uspostavlja odnos moći jer je odabran vertikalni kut na razini oka. Iako je predsjednik države, on je jednak ostalima i pristupačan im je. Analizirajući modalnost vidimo da fotografija nije ravnomjerno osvijetljena, što se najviše uočava na licu, čija je desna strana u sjeni. Na taj način podešeno svjetlo naglašava duboku boru među obrvama, koja ga čini zamišljenim i zabrinutim. Iz tako osvijetljenog lica i pogleda upućenog u daljinu može se iščitati poruka: „tu sam i brinem za sve vas“.

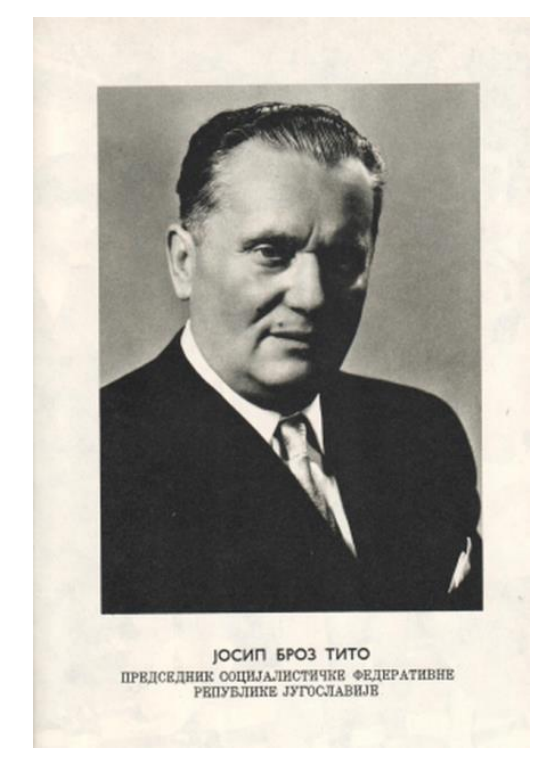

Slika 1. (preuzeto iz Mitić 1965.)

Susret sa slikom 2, čim se okrene prva stranica bukvara, predsjednika države približava učeniku prikazujući ga kao velikog prijatelja djece i osobu koju djeca vole. Slika pripada narativnim reprezentacijama u kojoj je prikazano nekoliko akcijskih procesa. Glavni akter je Tito, koji 
zauzima središnju poziciju na fotografiji i s obje ruke dodiruje dva dječaka. Pokroviteljski stavlja jednu ruku (vektor) dječaku (cilj) lijevo na glavu, a drugom (vektor) grli dječaka (cilj) zdesna. Oba dječaka su pozicionirani lagano ispred njega, a pored njega, s obje strane, stoje dvije djevojčice. One su blizanke u istim haljinama, cipelama i trakama u kosi, čime je ostvarena simetrija. Drugi dio simetrije ostvaruju dva manja dječaka koje dodiruje. Djevojčica s lijeve strane također je akter jer stavlja ruku (vektor) na rame dječaku (cilj) koji je ispred nje, a to je isti onaj dječak na čijoj glavi počiva Titova ruka. Interakciju sa korisnikom ostvaruje upravo taj dječak, koji mu upućuje direktan pogled i osmijeh (zahtjev) pokazujući kako su oni bliski s Titom i kako njih Tito voli („Tito može doći i u tvoju školu i družiti se s tobom“). Tito također upućuje direktan pogled korisniku, ali mu oči sakrivaju sunčane naočale, koji je udružen sa osmijehom. Kada je uz direktan pogled prisutan i osmjeh, djelovanje zahtjeva je pojačano jer akter traži da mu se osmijeh uzvrati. Od sedmero djece na fotografiji troje upućuje direktan pogled u kombinaciji sa osmijehom. Autorica ovih redova pretpostavlja da ova fotografija predstavlja prvi dan škole, kojom Tito pozdravlja učenike i želi im uspjeh u novoj školskoj godini - kao uvod na početku bukvara. Kada je riječ o modalnosti, ovdje je zanimljivo primijetiti da dječak zdesna Titu oko vrata ima pionirsku maramu, čime se identificira kao Titov pionir. Veću zastupljenost pionirskih uniformi vidjet ćemo u bukvaru iz 1974., a više riječi o samim uniformama i njihovoj ulozi bit će u cjelini poglavlja posvećenoj konceptu domovine.

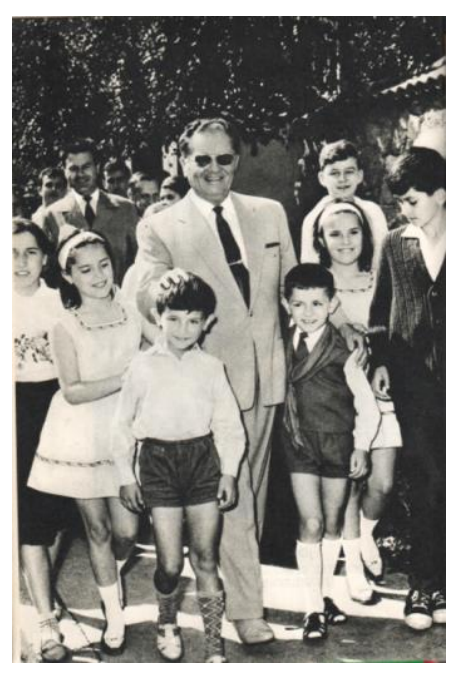

Slika 2. (preuzeto iz Mitić 1974.)

\subsubsection{Analiza jezičnog sadržaja u bukvaru iz 1965. godine}

Kada se Tito prikazuje kao društveni akter, prisutne su samo dvije vrste nominacije: (1) formalna, u kojoj se navode njegovo puno ime, prezime, nadimak i funkcija (Josip Broz Tito 
predsjednik Socijalističke Federativne Republike Jugoslavije, ispod portreta na početku bukvara) i (2) neformalna, u kojoj je imenovan svojim službenim nadimkom - Tito. Kategoriziran je svojom funkcijom - predsjednik, klasificiran dobno „najstariji u našoj armiji“”, a prisutno je iskazivanje pripadanja („Tito je $n a \check{s}^{(6)}$ koje je i uzajamno: „Mi smo Titovi, Tito je naš ${ }^{\varsigma}$. Analiza društvenih aktivnosti u kojima sudjeluje učestvuje pokazuje da su to dosljedno materijalne aktivnosti: mahati, ratovati, smiješiti se, stvoriti (armiju), štititi. Iz odabira glagola vidimo da je Tito prikazan kao ratnik, zaštitnik i osoba koju ljudi vole i uvažavaju - on uzvraća osmjehe i pozdrave (,Tata, Tito maše i smeši se. Tito je ratovao. On nas je štitio.“).

\subsubsection{Analiza slikovnog sadržaja u bukvaru iz 1974. godine}

U bukvaru iz 1974. godine Tito je na slici prikazan dva puta, jednom na samom početku bukvara (slika 3.), kao što je to slučaj u bukvaru iz 1965. godine, a drugi put na poštanskoj marki na kojoj je prikazan iz profila, u bliskoj udaljenosti. Oba slučaja su narativne reprezentacije, prijelazna i neprijelazna, u kojima izostaje Titov direktan pogled prema korisniku, pa vidimo ponudu koju prati osmijeh (slika 3.). Kod odabira plana prisutna je bliska i dugačka udaljenost, a u oba primjera se koristi prednji horizontalni kut i vertikalni na razini oka. U narednim redovima slijedi analiza slike 3 .

Slika 3 predstavlja sâm početak bukvara i za razliku od bukvara iz 1965. godine ovdje izostaje službeni portret predsjednika države, pa vidimo njegovu zajedničku fotografiju s učenicima. Riječ je o narativnoj reprezentaciji u kojoj je prisutan akcijski i reakcijski proces. Glavni reakter je Tito, pozicioniran u središnji dio fotografije. S obzirom na to da su djeca prilično tijesno okupljena oko njega, nije vidljivo jesu li njegove ruke možda vektori, što bi ga činilo akterom. Vidljiv je kao reaker, gdje vektor čini linija oka usmjerena prema djevojčici s lijeve strane, koja je ovdje pojava ili fenomen. Sudionici u vidljivom akcijskom procesu su pioniri, dječak koji je iza djevojčice u koju gleda Tito (stavlja svoje ruke - vektori njoj na ramena, pri čemu je ona $c i l j$ ) i dječak kojem se vidi samo dio glave, a stavlja ruke na rame djevojčici koja je druga zdesna Titu, ponavlja se identična situacija da je dječak akter, a djevojčica cilj. Ovdje je odabrana dugačka udaljenost jer je ipak riječ o grupnoj fotografiji, a horizontalni prednji kut i vertikalni na razini oka šalju poruku ,i ti si Titov pionir, Tito je kao i mi“. Interakciju sa korisnikom bukvara uspostavljaju djeca koja imaju direktan pogled - djevojčica i dječak koji čuče u prvom redu, djevojčica u drugom redu desno od Tita. Kod svih troje zahtjev je udružen sa osmijehom. Analiza modalnosti nam, osim informacije o tome da odabir kvalitetne fotografije u boji doprinosi realističnosti i uvjerljivosti poruke, govori i o hijerarhijskom sustavu 
i ulozi pionirske uniforme. Naime, ako usporedimo sliku 2 i sliku 3, vidimo da je na slici 2 Tito u građanskom odijelu, a djeca u običnoj odjeći, jer je on u ulozi predsjednika države, a oni su samo učenici. Na slici 3 Tito je u uniformi, pojavio se kao vrhovni komandant JNA, a djeca nose pionirske uniforme - oni su njegova vojska. Slika je tako i potpisana „Tito i pioniri“, djeca ovdje imaju svoju društvenu ulogu, asimilirana su u skupinu i pripadnost iskazuju nošenjem uniformi. U nastavku poglavlja, u dijelu posvećenom konceptu domovine, detaljno se analizira proces primanja u pionire kao obred inicijacije.

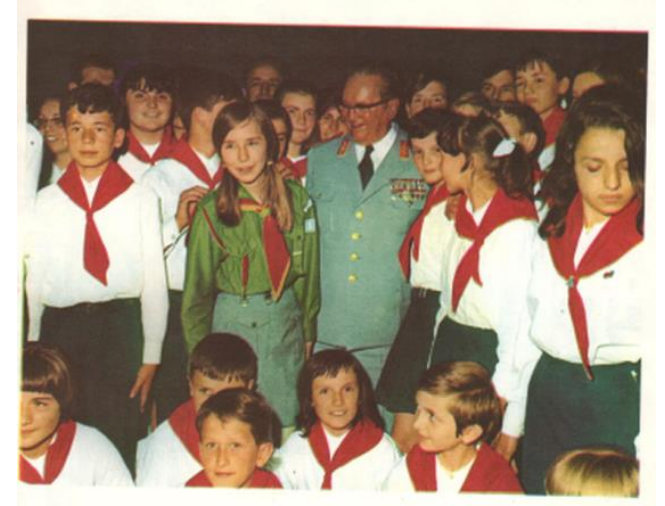

тито и пиониРи

(Slika 3. preuzeto iz Janjušević, Milardić, Timotijević 1974.)

\subsubsection{Analiza jezičnog sadržaja u bukvaru iz 1974. godine}

Pred kraj bukvara, u dijelu koji je posvećen uvježbavanju čitanja prisutna su dva teksta („I Joža je voleo da se sanka“ i „Kako je mali Joža čitao“) u kojima su prikazane anegdote iz Titovog djetinjstva koje ističu njegovu domišljatost i snalažljivost. Kad se prikazuje kao društveni akter, prisutna su dva načina nominacije - neformalna, nadimkom iz djetinjstva Joža, i neformalna popularnim nadimkom Tito. Titule se ne daju ispred imena Tito, samo se navodi kao drug (relacijska identifikacija), što ga čini jednakim ostalima. Dobno je klasificiran kao mali Joža. Ovakvim načinom prikazivanja Tita kao društvenog aktera postiže se jednakost sa korisnikom bukvara - „on je naš drug i isto je nekad bio nestašno dijete“. Kada je riječ o društvenim aktivnostima u kojima Tito sudjeluje, najzastupljenije su materijalne prijelazne aktivnosti: čuvati, juriti, sanjkati se, trčkarati, uzimati (,Joža je svaki dan čuvao kravu na livadi“). Uočavamo i dva primjera semiotičke prijelazne aktivnosti: voljeti („Kao i sva deca, i Joža je voleo sankanje“) i strijepiti („On je strepeo šta će biti kad se vrati kući..."). 


\subsubsection{Analiza slikovnog sadržaja u bukvaru iz 1996. godine}

Promjenom društvenih okolnosti i državnog uređenja lik Josipa Broza Tita nestaje iz bukvara, a umjesto njega javljaju se povijesne ličnosti koje nisu suvremenici korisnika bukvara - Vuk Karadžić i Sveti Sava. Vuk Karadžić je na slici prikazan dva puta, jednom na početku bukvara - slikarskim portretom (slika 4.), a drugi put crtežom u drugom dijelu bukvara (str. 90). U oba primjera riječ je o narativnim reprezentacijama u kojima je prikazan neprijelazni akcijski (slika 4) i prijelazni akcijski proces (str. 90) kod kojeg je vektor ruka, sredstvo predmet za pisanje (crtež sa nejasnim linijama), a cilj je papir. Obje slike daju srednju udaljenost i vertikalni kut na razini oka kod kojeg nema iskazanog odnosa moći. Slika na str. 90 prikazuje Vuka Karadžića pod djelomično kosim horizontalnim kutom, a priložena je kao ilustracija pjesme Ranka Simovića „Vuku Karadžiću“, koja prikazuje čime se Karadžić bavio i za što se zalagao. Dakle, i sadržaj pjesme i odabir djelomično kosog horizontalnog kuta odašalju poruku da ova osoba ne pripada korisnikovu svijetu, da nije njegov suvremenik. Interakciju s korisnikom bukvara uspostavlja portret na slici 4, koji će biti posebno analiziran, dok u drugom slučaju (str. 90) zatječemo ponudu.

Slika 4 pozicionirana je u bukvaru iz 1996. na istom mjestu na kojem se nalazi Titov službeni portret u bukvaru iz 1965. godine - na samom početku. Karadžićev portret potpisan je njegovim punim imenom i prezimenom - Vuk Stefanović Karadžić. Za razliku od Tita, on ostvaruje interakciju, upućuje direktan pogled (zahtjev) ozbiljnog izraza lica, kao da traži da mu se ukaže poštovanje. Prikazan je na srednjoj udaljenosti, čime se približava korisniku bukvara, a odabirom prednjeg horizontalnog kuta šalje se poruka: „Ja pripadam tvom svijetu, ja sam sastavio azbuku koju ćeš ti iz ove knjige učiti“. Nema iskazanog odnosa moći, budući da je prikazan pod vertikalnim kutom na razini oka. Kod analize modalnosti zanimljivo je usporediti ovaj portret sa slikom na str. 90, jer je na obje Vuk prikazan kao star čovjek, ima sijedu kosu i dugačke sijede brkove, što potencira autoritet, životno iskustvo i mudrost. Odjeven je u građansko odijelo, ali na glavi nosi fes, koji predstavlja vezu sa narodom i zavičajem iz kojeg je potekao, a simbolizira i njegovo bavljenje zapisivanjem narodnih umotvorina. Na slici je izražen kontrast između lica i tijela s pozadinom, jer su lice (s brkovima i kosom) i košulja najosvjetljeniji. Ramena se jednim dijelom stapaju s pozadinom i njegov lik kao da izranja iz mraka. 


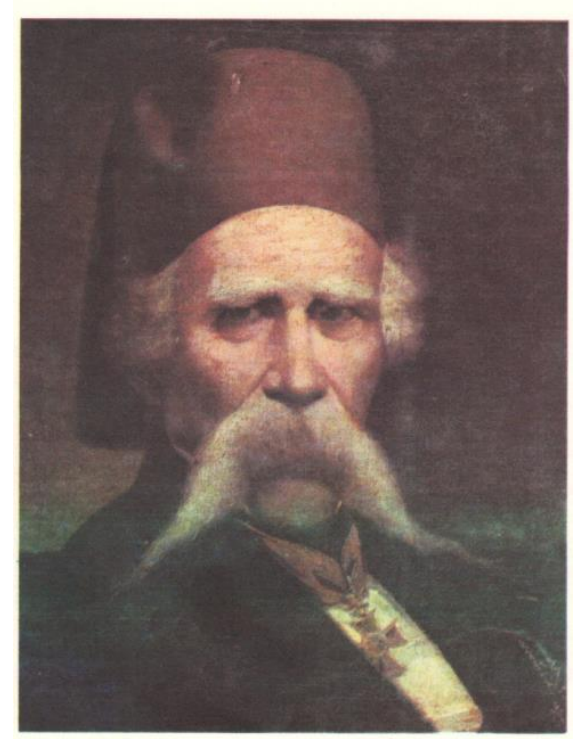

Вук Стефановић Караџић

(Slika 4. Preuzeto iz Milatović, Ivković 1996.)

Sveti Sava u ovom bukvaru nije prikazan slikom, već narodnom pričom (str. 101) u kojoj je u ulozi učitelja koji zahvaljujući vlastitoj domišljatosti odgoneta koji učenik je kradljivac meda (onome koji je ukrao med, past će pčela na kapu). Crtež ispod spomenute narodne (slika 5) priče ilustrira opisani događaj s dva dječaka, ali sam Sveti Sava nije prikazan likom. Ovdje dajemo taj crtež radi kasnije usporedbe prikaza Svetog Save u bukvaru iz 2011. godine.

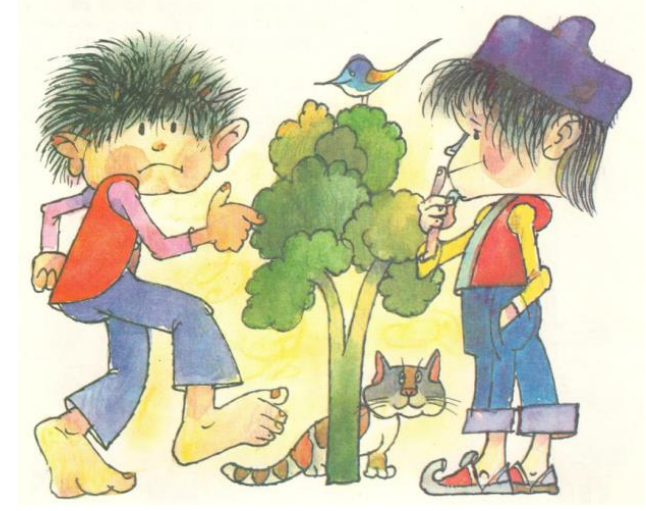

(Slika 5. Preuzeto iz Milatović, Ivković 2011.)

\subsubsection{Analiza jezičnog sadržaja u bukvaru iz 1996. godine}

Kao društveni akter Vuk Karadžić je predstavljen formalnom nominacijom, svojim punim imenom i prezimenom, a potom i neformalno, samo imenom Vuk. Kada je u ulozi društvenog aktera, sudjeluje u materijalnim prijelaznim aktivnostima (sakupljao narodne pjesme, priče), 
semiotičkoj prijelaznoj (,hteo da se ljudi opismene“) i semiotičkoj bihevioralnoj (,Vuk je bio dobre volje, prepun sreće $\left.e^{6}\right)$. Sveti Sava je kao društveni akter prisutan pod formalnom kanonskom nominacijom - Sveti Sava, a kategoriziran je funkcionalizacijom jer je u ulozi učitelja (,Sveti Sava bio je i učitelj $\left.{ }^{\star 6}\right)$. Kada je riječ o društvenoj aktivnosti, on sudjeluje u materijalnim prijelaznim aktivnostima: pronaći, uzviknuti (,Da bi pronašao kradljivca, Sveti Sava uzvikne glasno svojim đacima“).

\subsubsection{Analiza slikovnog sadržaja u bukvaru iz 2011.}

Vuk Karadžić i Sveti Sava u ovom su bukvaru slikovnim prikazima zastupljeniji u odnosu na bukvar iz 1996. godine. Karadžić je prikazan triput, a Sveti Sava jednom. Karadžić se javlja na dva portreta - na samom početku bukvara (slika 6), kao što je to slučaj i u bukvaru iz 1996. godine, te u drugom dijelu bukvara prije tekstova za uvježbavanje čitanja (slika 7). Oba portreta su narativne neprijelazne reprezentacije u kojima je odabran prednji horizontalni kut, vertikalni na razini oka i srednja udaljenost, što ih približava korisniku bukvara i predstavlja kao dio njegovog svijeta. Na slici 6 Karadžić je tijelom blago zakrenut, što bi mogao biti djelomični kosi horizontalni kut, ali je licem ipak okrenut naprijed, što ga približava korisniku bukvara. Interakciju ostvaruje portret na slici 7, na kojoj je iskazan zahtjev ozbiljnim izrazom lica, dok je na slici 6 prisutna samo ponuda. Vuk je na slici 7 puno mlađi nego što se inače prikazuje u udžbenicima srpskog jezika - ima crnu kosu i tanke crne brkove, bez fesa na glavi. Odjeven je prema modi tog vremena (naborana košulja s visokom kragnom i kaput) i direktnim pogledom od promatrača traži da ga ovaj doživi kao učenog mladog čovjeka i gospodina. Kada je riječ o modalnosti, u oba primjera imamo slikarske potrete na kojima dominiraju slične boje s toplim crvenkastim tonovima. Oba su dana u okruglom okviru koji je ukrašen i izgleda kao stari obiteljski portret, čime se postiže familijarnost i percepcija Vuka Karadžića kao daljnjeg rođaka iz prošlosti. Na slici 6 Vuk ima fes na glavi kao i na portretu na početku bukvara iz 1996. godine, mlađi je jer nema sasvim sijede brkove i kosu, ali je opet u dovoljno zrelim godinama koje mu daju potreban autoritet i iziskuju poštovanje od promatrača. 


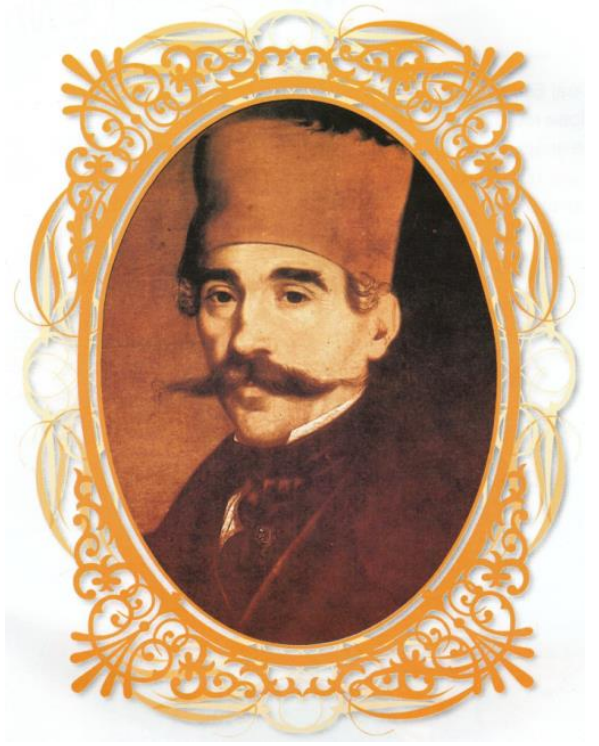

(Slika 6. Preuzeto iz Milatović, Ivković 2011.)

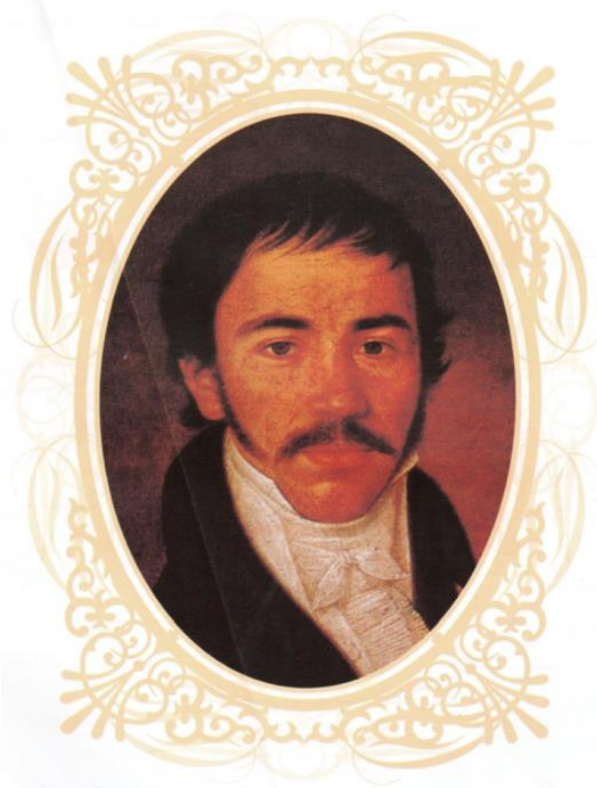

(Slika 7. Preuzeto iz Milatović, Ivković 2011.)

Treći Karadžićev slikovni prikaz (slika 8) javlja se u drugom dijelu bukvara, kada su svladana sva slova i uvježbava se čitanje. Posebnu analizu treba dati i za sliku 8, koja se nalazi u drugom dijelu bukvara u kojem su već savladana sva slova i uvježbava se čitanje. Ova slika pripada narativnim reprezentacijama na kojoj je prikazan reakcijski i akcijski proces. U reakcijskom procesu Karadžić je u ulozi reaktera, njegov pogled čini vektorsku liniju usmjerenu prema učenicima u klupi koji su fenomen ili pojava. Učenici su pak dio akcijskog procesa jer su oboje akteri za sebe. I dječak i djevojčica čine isto - oboje su akteri, vektori su njihove ruke, sredstva olovke, a cilj bilježnice u koje pišu. Interakcija ovdje izostaje, jer nijedan od aktera ne upućuje direktan pogled promatraču, tako da je prikazana samo ponuda. Kod odabira plana ovdje se daje srednja udaljenost, prednji horizontalni kut, ali prvi i jedini put u bukvaru prikazan je blagi visoki vertikalni kut kojim je korisniku dana pozicija moći. Omogućeno mu je da vidi ono što i Karadžić, da nadgleda njihovo pisanje. Promatrajući modalnost vidimo da se Karadžić ovdje pojavljuje u svojem prepoznatljivom izdanju, s dugačkim sijedim brkovima, sijedom kosom i crvenim fesom na glavi. Pozadinu čini zid na kojem su slova prikazana kao sjene, što dodatno pojačava radnu atmosferu u kojoj dječak i djevojčica na slici savladavaju pisanje. 


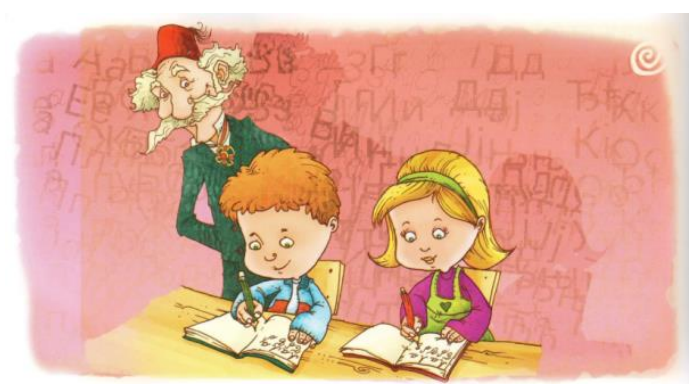

(Slika 8. Preuzeto iz Milatović, Ivković 2011.)

Sveti Sava se u ovom bukvaru prvi put pojavljuje svojim pravim likom, preuzetim sa freske. Ne ostvaruje interakciju sa promatračem, jer je zagledan u daljinu (ponuda) ozbiljnog izraza lica. Prikazan je na srednjoj udaljenosti, iz prednjeg horizontalnog kuta i vertikalnog na razini oka. Ovim odabirom postignuta je bliskost s korisnikom bukvara jer tako prikazan Sveti Sava čini dio korisnikova svijeta. Odabir portreta s freske nije slučajan jer se ona nalazi u manastiru Mileševa, u kojem su se čuvale mošti Svetog Save sve do 1594. godine, kada su ih Turci spalili u Beogradu na Vračaru. Manastir Mileševa podigao je srpski kralj Stefan Vladislav u 13. stoljeću kao svoju zadužbinu (zakladu), a on je pak bio sin Savinog brata Stefana Prvovenčanog. Manastir se nalazi u Srbiji, prema granici s Crnom Gorom. U bukvaru iz 1996. Sveti Sava uopće nije prikazan likom, slika 5 ilustrira situaciju opisanu u narodnoj priči, a isti tekst narodne priče nalazi se i u bukvaru iz 2011. godine. Ipak, ovdje vidimo sliku sveca, a ne učitelja. Ovakav odabir u skladu je s jačanjem Srpske pravoslavne crkve, koja je svakako utjecajnija 2011. godine nego što je bila sredinom devedesetih godina prošlog stoljeća.

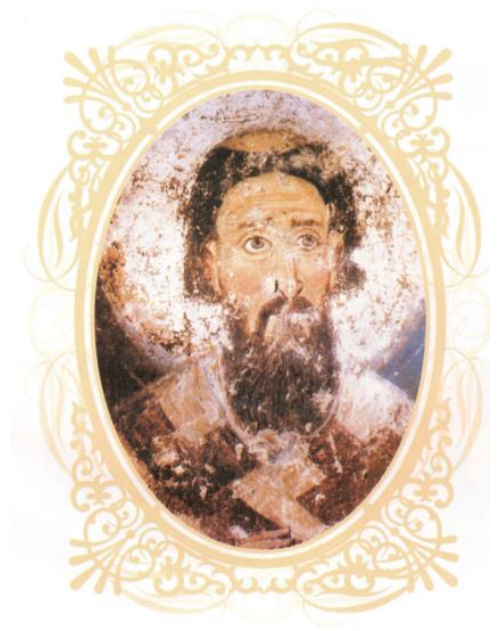

(Slika 9. Preuzeto iz Milatović, Ivković 2011.)

\subsubsection{Analiza jezičnog sadržaja u bukvaru iz 2011. godine}


Tekstovi u kojima se spominju Vuk Karadžić i Sveti Sava identični su onima u bukvaru iz 1996. vidi pod 1.2.6.

\subsection{Koncept domovine}

\subsubsection{Analiza slikovnog sadržaja u bukvaru iz 1965. godine}

Domovina je u ovom bukvaru implicitna slika države, prikazana analitički što će posebno biti prikazano i tumačeno na slici 10 i 11, pioniri, gorani, i zastava kao državni simbol, Jugoslavenska narodna armija i armija koju čine djeca igrajući se da su vojska. Svi ovi elementi koji čine domovinu u nastavku rada su prikazani zasebno analizom i interpretacijom najmanje po jedne ilustracije.

Implicitnu sliku države nalazimo na stranicama 16 i 17, na kojima je po jedan slikovni prikaz. Treba ih promatrati zajedno jer predstavljaju jedinstvenu konceptualnu reprezentaciju, koja se sastoji od cjeline i dijelova. Riječ je o analitičkom procesu u kojem su dijelovi prikazani na lijevoj stranici (slika 10), a cjelina na desnoj (slika 11). Dijelove čini osam crteža na kojima su prikazani ratar, ovčar, zidar, obućar, auto-mehaničar, stolar, metalurški radnik i cestar. Dakle, prikazana su manualna zanimanja i svi ovi radnici svojim rukama grade domovinu - to je zemlja u kojoj nitko nije gladan (ratar i ovčar), živimo i radimo u dobrim kućama/zgradama (zidar), obuveni smo (obućar), imamo čamce, tvornice, brodove, tešku industriju, mostove i ceste koje nas spajaju. Svi su oni svojim rukama izgradili SFRJ, koja je pak prikazana na desnoj strani, na slici br. 11. Ta slika vrlo zgusnuto daje sve što bi moglo činiti jednu modernu i izgrađenu prosperitetnu zemlju. Avion i helikopter predstavljaju modernizaciju: vlak razvijen željeznički prijevoz koji povezuje najudaljenije krajeve zemlje, konj i kola život na selu i privrženost zemlji, automobili mogućnost osobnog prijevoza, što je također moderno, kamioni ukazuju na razvijenu industriju, privredu, trgovinu, prijevoz raznih vrsta roba, teretni brodovi i podmornica na modernizaciju vojske, ali istovremeno i na razvoj metalurške industrije, što ne ometa ni male čamce koji služe za prijevoz ribara. Ako povučemo zamišljenu vodoravnu liniju preko slike, vidimo da se gornji dio odnosi na selo, a donji na grad, koji je u prvom planu i dominira. Promatrajući modalnost, vidimo da analitički dio (slika 10) nema detalje i pozadinu, to su jednostavni crteži bez dubine i slojeva, dok dio koji predstavlja cjelinu (slika 11) nudi bogatstvo boja, dubinu, detalje i sl. pa je modalnost viša. 


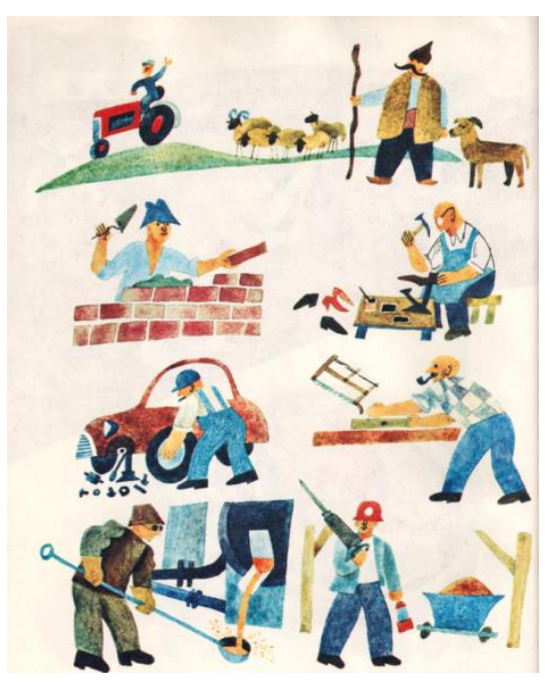

(Slika 10. Preuzeto iz Mitić 1965.)

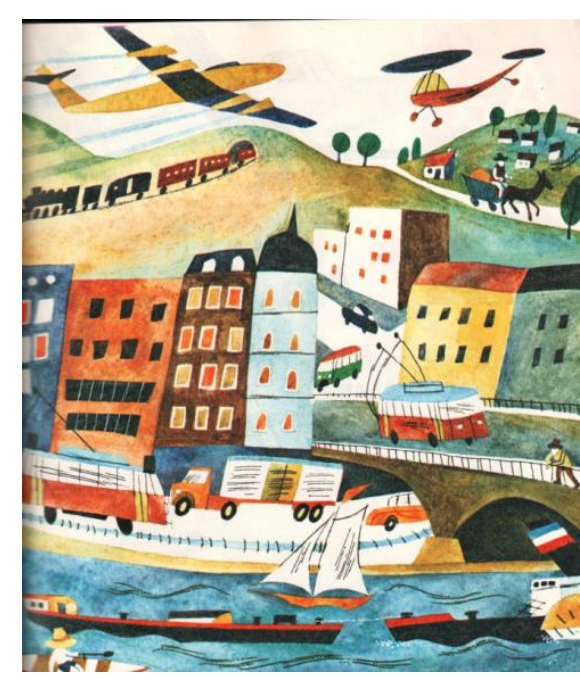

(Slika 11. Preuzeto iz Mitić 1965.)

Pioniri su u bukvaru iz 1965. godine prikazani pet puta. To su neizostavno narativne reprezentacije u kojima su prezentirani kroz akcijske procese. Akteri su dječaci i djevojčice koji nose pionirske marame, ili su slike u funkciji ilustracije tekstova, koji aktere ne imenuju kao djecu ili učenike, nego kao pionire. Vektori su ovdje ruke koje za sredstva imaju oružje, nalivpero, kramp, lopatu, krpu (slika 13), slova koja se postavljaju na zid, čekić. Ciljevi su im drugi dječaci u ulozi neprijatelja kada se igraju rata, Titov portret na zidu koji ukrašavaju lovorovim granama, jelka koju kite za proslavu Nove godine. Prisutan je jedan primjer pratnje u prikazu igre rata (str. 85) na kojem je djevojčica pratnja. Ova slika će biti posebno analizirana u dijelu poglavlja koje se bavi rodnim odnosima. Interakciju s korisnikom pioniri ostvaruju direktnim pogledom (zahtjev) koji upućuju i dječaci i djevojčice, ali je prisutna i ponuda. Izbor plana uglavnom je srednja ili dugačka udaljenost, što je logičan izbor budući da se svaki put radi o prikazu nekakve aktivnosti. Horizontalni kut je dosljedno prednji, što odašalje poruku da je sve što čine pioniri dio korisnikova svijeta i da to može biti ili već jest on. Vertikalni kut je na razini oka svugdje osim na stranici 75, gdje je blagi visoki vertikalni kut (slika 12). Ovakav izbor kuta rijedak je u bukvarima, a sličan se primjer javlja u bukvaru iz 2011. godine, gdje na crtežu Vuk Karadžić nadgleda kako dječak i djevojčica pišu (slika 8.). Korisniku je i ovdje dana moć da na isti način nadgleda kako pionir piše pismo ocu u kojem ga izvještava o poslovima na izgradnji auto-puta. Sličan primjer prisutan je i na str. 75, gdje dječak u svoj dnevnik zapisuje koje drveće je zasadio. Gorani su prikazani dva puta - na str. 74, gdje dječak i djevojčica sade drvo (oboje su akteri, ruke su im vektori, sredstva lopata i stablo, ciljevi rupa u zemlji) te na str. 75 . Svi crteži imaju nisku modalnost, jednostavni su bez detalja, dubine, bogatstva boje i sl. Djeca ne nose pionirske uniforme kada se igraju ili rade, npr. ukrašavaju učionicu ili su na radnoj akciji 
(slika 13). Gorani sade drvo u uniformama, ali kada dječak piše dnevnik o tome šta je zasadio (str. 75) ne nosi uniformu. Možemo zaključiti da uniforma ovdje funkcionira kao radno odijelo.

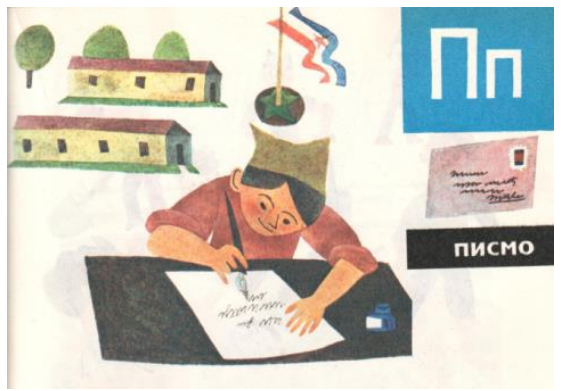

(Slika 12. Preuzeto iz Mitić 1965.)

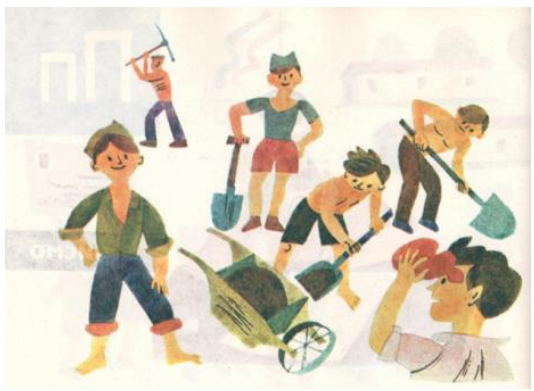

(Slika 13. Preuzeto iz Mitić 1965.)

Armija se u bukvaru prikazuje na str. 52 i 53 (slika 14) koja zapravo čini jedinstvenu sliku, a nalazi se na stranicama bukvara koje su jedna nasuprot druge. To je narativna reprezentacija, akcijski proces u kojem su akteri vojnici, vektori su ruke koje pozdravljaju, a cilj je Tito, koji se nalazi na str. 52 u vozilu ispred. Prijevozno sredstvo su tenkovi i otvorena vojna vozila. Ovdje nema uspostavljanja interakcije s korisnikom, imamo ponudu i prikaz iz dugačke udaljenosti, iz prednjeg horizontalnog kuta i vertikalnog na razini oka, pa poruka glasi „ovo je tvoja armija i ti možeš biti dio nje“. Modalnost je niska, vojnicima se ne vide lica, pozadina je dana u obrisima, nema detalja na slici, ali je jasno istaknuta puna ratna sprema jer su u tenkovima, sa šljemovima na glavama.

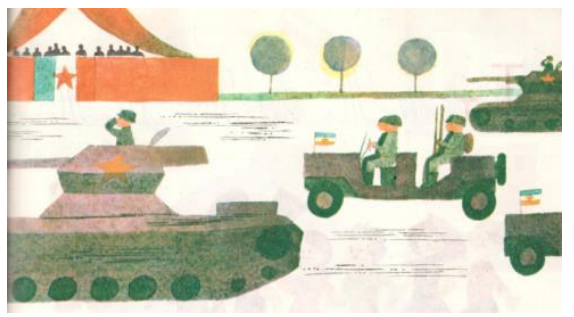

(Slika 14. Preuzeto iz Mitić 1965.)

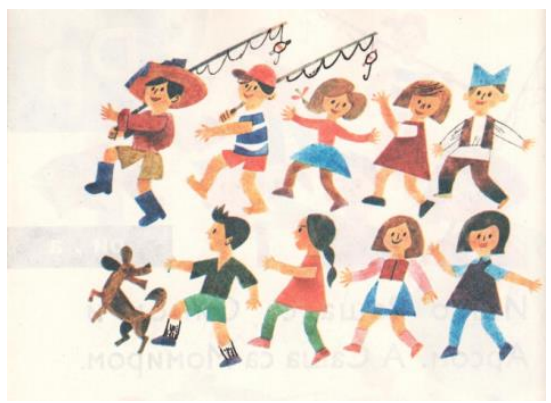

(Slika 15. Preuzeto iz Mitić 1965.)

Kada se djeca igraju da su armija (slika 15 i slika na str. 54) opet su prikazani kroz narativnu reprezentaciju i akcijski proces. Akteri su djevojčice i dječaci, njihove ruke su vektori, a sredstva ribički štapovi (slika 15), metle i lopate (slika na str. 54) U oba primjera cilj je nevidljiv, tj. nije prikazan, što je glavna razlika u odnosu na pravu armiju, koja brani i čuva Tita i domovinu. Ipak, djeca ostvaruju kontakt direktnim pogledom sa čitaocem bukvara (zahtjev i u kombinaciji sa osmijehom), ali je prisutna i ponuda. Armija koju čine djeca 
prikazana je iz dugačke udaljenost, upotrebom prednjeg horizontalnog kuta i vertikalnoga na razini oka šaljući poruku „ovako se i ti igraš i mi smo isti kao i ti““.

Zastava SFRJ-a (plavo, bijelo i crveno polje sa petokrakom zvijezdom u sredini) prisutna je na slici koja prikazuje vojnu paradu (slika 14) na kojoj je okrenuta okomito, nalazi se na automobilu u kojem se vozi Tito (str. 52), drži je u rukama dječak koji ukrašava školu za Dan Armije (str. 78): prisutna je u drugom planu na slici gdje dječak ocu piše pismo sa radne akcije (slika 12), drže je ljudi koji dočekuju prolazak Tita (str. 57), nalazi se na slici brodića koji je dio analitičke strukture u prikazu dječje igre puštanja lađica niz potok (str. 99). Zanimljivo je primijetiti kako se partizani spominju samo u tekstu, dok ih u slikovnim prikazima nema - možda stoga što njihova borba pripada prošlosti, a bukvar slikom akcent stavlja na sadašnjost, obnovu i očuvanje zemlje i sve ono što je postignuto.

\subsubsection{Analiza jezičnog sadržaja u bukvaru iz 1965. godine}

Domovina se u jezičnom sadržaju ne javlja kao društveni akter, nego je aktivnost pionira usmjerena prema domovini u smislu da je oni čuvaju, brane (materijalna prijelazna aktivnost) i vole (semiotička prijelazna). Već u samom nazivu 'pioniri' imamo asimilaciju i funkcionalizaciju, ali kada se igraju rata izdvajaju se iz grupe poluformalnom nominacijom, pa se pojavljuju imena: Ljubiša, Ljiljana, Ljubomir, Čeda, Žarko, Živan, Snežana, Petar i neka od imena sadrže u sebi značenje mira (Čedo, skraćeno od Čedomir, Ljubomir u značenju, ljubiti, voljeti mir). Funkcionalizacijom pioniri dobivaju konkretnije uloge, pa su prisutni bolničarka, komandir i vojska (mlada vojska Titova - dobna klasifikacija i posevizacija). Na str. 85 pioniri se igraju rata, navode se njihova imena, ali dječaci koji su u ulozi neprijatelja ostaju bezimeni. Oni ostaju asimilirani u zbirnoj imenici „neprijatelj““. Gorani (funkcionalizacija i asimilacija) imaju imena - Dragan i Radmila, a simbolika je ovdje prisutna u imenu djevojčice jer je njoj rad mio, vrijedna je. U dijelu poglavlja koji se bavi rodnim odnosima bit će više riječi o imenima dječaka i djevojčica i značenjima tih imena. Partizani (asimilacija, funkcionalizacija) spominju se u kontekstu ratne borbe i prikazuju se kroz posevizaciju - naši partizani, dok je Armija (asimilacija i funkcionalizacija) ipak istaknutija i ima veću ulogu. Također je dana kroz posevizaciju (naša Armija, Titova Armija), ali je prisutno poistovjećivanje sa njom gdje se pojedinac asimilira „Armija - to smo mi svi.“ Armija kao društveni akter sudjeluje učestvuje u materijalnoj prijelaznoj aktivnosti - marširati, i materijalnoj prijelaznoj instrumentalnoj-imati golubove pismonoše. Na stranicama 34, 35, i 54 već utvrđen koncept armije spušta se na razinu 
djeteta, gdje jedan dječak formira svoju armiju koju čine djevojčice i dječaci i svi skupa marširaju poput prave armije.

Kada je riječ o društvenoj aktivnosti, pioniri najčešće sudjeluju materijalnoj prijelaznoj aktivnosti: rušiti stijene, nasipati rupe, ravnati put, nositi krampove, pjevati, ukrašavati školu, popeti na ljestve, pružati slova i čavle sastaviti parolu, razviti zastavu, okititi sliku, iskititi jelku. Prisutna je i materijalna prijelazna interaktivna aktivnost: igrati se (rata), čekati (neprijatelja), komanduju, ali i materijalna prijelazna instrumentalna: imati sablju, sakriti se u žbunje. Kada je radnja materijalna neprijelazna, uključuje samo dva glagola: pjevati i igrati.

\subsubsection{Analiza slikovnog sadržaja u bukvaru iz 1974. godine}

Za razliku od bukvara iz 1965. godine, u bukvaru iz 1974. godine nema ni implicitnog slikovnog prikaza domovine. Od elemenata koji prezentiraju domovinu pojavljuju se pioniri i vojska, a u vidu ukrasa provlače se boje zastave. Petokraka zvijezda javlja se na pionirskim kapama i šljemovima vojnika JNA. Kao ni u bukvaru iz 1965. godine, partizani nisu prikazani slikom.

Pioniri se prvi put pojavljuju odmah na početku bukvara, $i$ to na zajedničkoj fotografiji s Titom (vidi 1.2.3.), a kasnije su dvije stranice posvećene svečanosti primanja u pionire, koje ćemo ovdje detaljno analizirati. Oba prikaza pionira su narativne reprezentacije, i to su akcijski procesi. Akteri su pioniri - djevojčice i dječaci i Tito, a ciljevi su drugi pioniri, bubanj, dječak koji svira klavir. Vektori su same ruke ili u kombinaciji sa bubnjarskim palicama i dirigentskom palicom. Kod ostvarivanja interakcije s korisnikom ostvaruje se ponuda, ali i zahtjev, koji je udružen sa osmijehom koji upućuju djevojčica i dječak. Kod ponude pogled nije direktno usmjeren na korisnika, ali u ovoj situaciji akteri imaju zatvorene oči (samo primjeri slike 16 i 17), što je znak potpunog povjerenja i to ćemo posebno analizirati. Pioniri su dosljedno prikazani na srednjoj udaljenosti iz horizontalnog prednjeg kuta i vertikalnog na razini oka, što ih približava korisniku i svrstava u domenu njihovog svijeta bez iskazivanja odnosa moći.

Slike 16 i 17 sačinjene su od 11 zasebnih cjelina koje prikazuju različite radnje kao u stripu, a od kojih je 7 slikovnih prikaza. Nemamo dosljedno akcijske procese jer u nekima izostaju vektori, ali imamo identičnu upotrebu horizontalnog prednjeg kuta i vertikalnog na razini oka, kao i srednje udaljenosti. Kada je riječ o interakciji, zahtjev udružen sa blagim osmijehom imamo svugdje na slici 16, ali na slici 17 situacija se mijenja. Prateći jezični dio, saznajemo da slikovni prikazi ovdje daju aktere od trenutka kada postaju pioniri. Oni zatvaraju 
oči, prepuštajući se pjesmi koju izvode. Ovdje je dijelom riječ o zanosu, ali da bismo zatvorili oči, a pritom bili okrenuti prema nekome, potrebno je povjerenje, pa se iz ovoga iščitava i poruka „Vjeruj, i ti ćeš ovako postati pionir“. Čin stupanja u pionire poseban je, svečan i na kraju donosi poseban osjećaj prikazan na licima pionira.

Modalnost je ovdje niska, ali unatoč tomu daje puno informacija u analizi. Između izgleda dvojice dječaka koji se pojavljuju u dnu slike 16. i pri vrhu slike 17 razlike su minimalne, $\mathrm{i}$ to samo $\mathrm{u}$ frizuri i odabiru odjeće. Ostala djeca također izgledaju gotovo preslikano, svi istih crta lica, istih izraza na licima s minimalnim odstupanjima u odabiru odjeće, koja pak dolazi u tri varijacije: jednobojne majice, majice/košulje s prugama i točkicama. Oni su i svojim izgledom asimilirani u jedinstvo pionirske zajednice, stapajući se jedni s drugima. Sâm čin primanja u Savez pionira polaganjem partizanske zakletve tradicionalno se održavao 29. studenog. To je zimsko doba godine, međutim ove su slike pune cvijeća, laganih oblaka koji plove nebom i cjelokupna atmosfera asocira na dolazak proljeća i buđenje prirode. Simbolika ovdje leži upravo u buđenju i novom početku, jer primanje u pionire svojevrsni je proces inicijacije, ulazak u svijet odraslih, prihvaćanje pravih obaveza i odgovornosti. Kape su ovdje zelene boje, mada su prave pionirske kape bile plave, što u ovom primjeru čini vezu sa partizanskim zelenim kapama, ali i tadašnjim kapama JNA. Na taj je način prisutna veza i jedinstvo na relaciji partizani - pioniri - JNA. Svaki pionir je partizanski potomak i može postati vojnik.

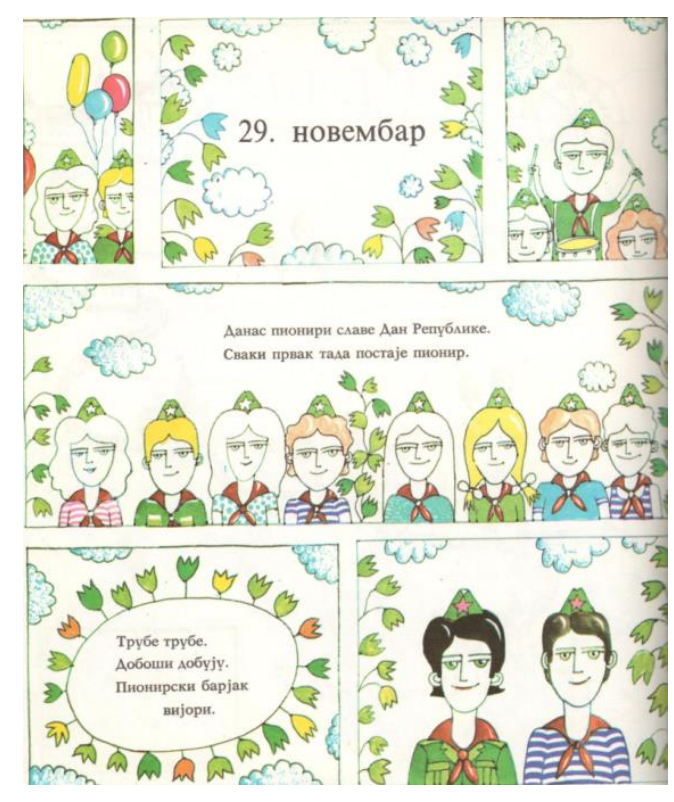

(Slika 16. Preuzeto iz preuzeto iz Janjušević, Milardić, Timotijević 1974.) 


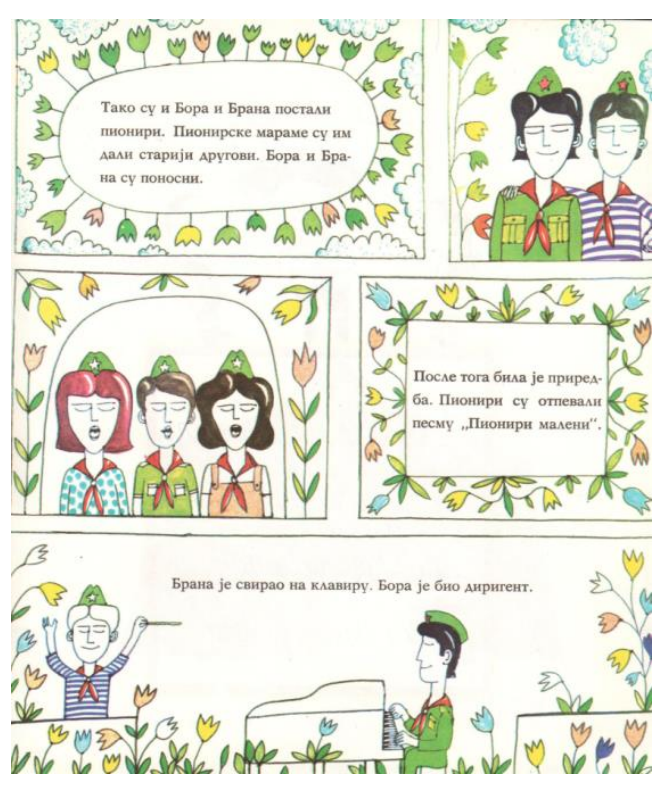

(Slika 17. preuzeto iz Janjušević, Milardić, Timotijević 1974.)

Vojska se u ovom bukvaru javlja u narativnim reprezentacijama koje su akcijski procesi. Akteri su pilot u helikopteru, vojnik i padobranac. Ciljevi su komande u helikopteru, zastava (slika 18.) i zemlja, tj. tlo. Sredstva su padobrani, puške i truba (slika 18.). Vojnici, u kojoj god da su ulozi, ne uspostavljaju direktan pogled, pa imamo samo ponudu. Prikazani su upotrebom prednjeg horizontalnog kuta i vertikalnog na razini oka na dugačkoj i srednjoj udaljenosti, što unatoč izostajanju zahtjeva šalje poruku: ,ja sam tvoja vojska“. Modalnost je na slikovnim prikazima vojske slična onoj sa pionirima, vojnici su identični, stapaju se svojim crtama lica i čine jedno.

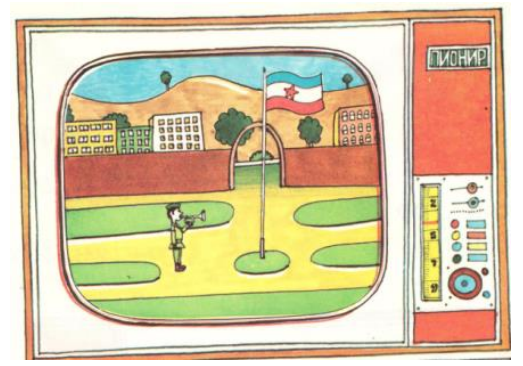

(Slika 18. preuzeto iz Janjušević, Milardić, Timotijević 1974.)

Zastava je prisutna u prostoru oko pjesama koji je izveden kao ukrašena margina, sadrži boje zastave gdje dominiraju kombinacije plav, bijel i crven te crven, bijel i plav. U okviru konceptualnih reprezentacija kod usvajanja slova, daju se slike brodova, topova, helikoptera i prisutnost crvene zvijezde petokrake na zastavama je nedosljedno. Petokraka se nalazi i na kapi dječaka koji je prikazan nasuprot djevojčice koja nema pionirsku kapu na glavi, ali o tom konkretnom primjeru će biti više riječi u dijelu poglavlja posvećenom rodnim odnosima. 


\subsubsection{Analiza jezičnog sadržaja u bukvaru iz 1974. godine}

Partizani, iako izostaju u slikovnom prikazu, prisutni su u jezičnom sadržaju - u tekstu pjesme kao društveni akteri u kojoj su klasificirani kao zeleni jablani, čime se naglašava njihova mladost. Partizanke su tjelesno identificirane kao omorike tanke, čime se naglašava njihova vitkost. Vojska već u svom nazivu ima i funkcionalizaciju i asimilaciju, izdvaja se pilot koji je klasificiran kao hrabar, a svojom funkcijom je izdvojen od ostatka vojske. Kod pionira kao društvenih aktera susrećemo poluformalnu nominaciju u osobnim imenima Bora i Brana, proces identifikacije se usmjerava na emociju ponosa, koji se javlja nakon što postaju pioniri, a klasificirani su dobno ili tjelesno - maleni. Pioniri učestvuju u materijalnim prijelaznim instrumentalnim aktivnostima: slaviti Dan Republike, pjevati pjesmu. Iako je od završetka Drugog svjetskog rata u trenutku pojave ovog bukvara prošlo 29 godina, domovina se i dalje pojavljuje u kontekstu obrane. U pjesmi posvećenoj domovini ona se brani knjigom, pjesmom, suzom, brigom, brašnom, ljepotom, čašću, znanjem, životom, lijepim odgojem. Postavlja se pitanje kakav neko treba biti da bi branio domovinu - obrazovan, suosjećajan, brižan, vrijedan, častan, odgojen itd.

\subsubsection{Analiza slikovnog sadržaja u bukvaru iz 1996. godine}

U ovom bukvaru imamo samo jedan slikovni prikaz domovine i riječ je o ilustraciji teksta pod naslovom „Jasna pozdravlja domovinu“ (slika 19.) To je narativna reprezentacija, akcijski proces u kojem je djevojčica akter. Vektori su njezine ruke i cvijeće koje drži u svakoj ruci, a cilj su drveće i ptica. Ona ostvaruje interakciju s korisnikom jer mu upućuje direktan pogled i osmijeh (zahtjev - „ovako ja pozdravljam domovinu“), prikazana je na srednjoj udaljenosti, iz prednjeg horizontalnog kuta i vertikalnog na razini oka što je približava čitaocu. Modalnost je ovdje niska i vidimo da domovina nema niti jedno državno obilježje poput primjerice zastave - domovina je izjednačena sa prirodom. Slike aviona i topa, koje susrećemo kao ilustracije slova ili dio jezične igre, nemaju na sebi zastavu. 


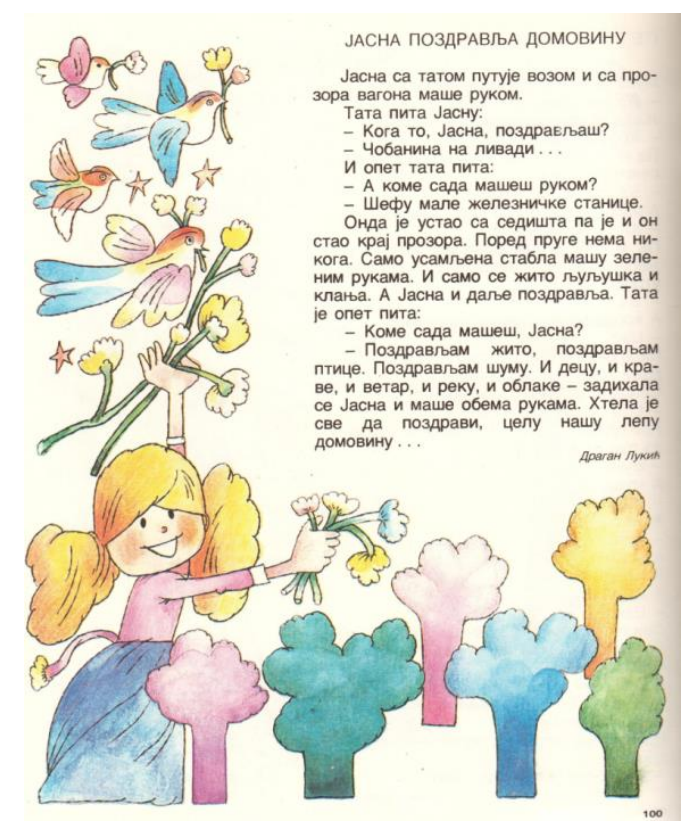

(Slika 19. Preuzeto iz Milatović, Ivković 1996.)

\subsubsection{Analiza jezičnog sadržaja u bukvaru iz 1996. godine}

U jezičnom prikazu domovine u ovom bukvaru na str. 100 ona je konceptualno izjednačena s planetom Zemljom i svime što čini život na njoj. Ne funkcionira kao društveni akter, a aktivnost koja je usmjerena prema njoj kao takvoj jest mahanje, pozdravljanje svih elemenata koji je čine (žito, ptica, vjetar, rijeka itd.). Naziv države spominje se na str. 67 u kratkom tekstu o Beogradu, gdje se samo navodi „Beograd - glavni grad Jugoslavije“.

\subsubsection{Analiza slikovnog sadržaja u bukvaru iz 2011. godine}

U bukvaru iz 2011. nema slikovnog prikaza domovine, a ni prisutnosti državnih simbola.

\subsubsection{Analiza jezičnog sadržaja u bukvaru iz 2011. godine}

Kako izostaju slikovni prikazi elemenata koji bi činili domovinu, tako je nema prisutne ni u jezičnim sadržajima. Naziv države ne spominje se nijednom, a samo se u okviru dvije rečenice spominju riječi domovina i otadžbina, stoga ih je teško podvrgnuti analizi društvenih aktera i društvene aktivnosti. Prvi primjer nalazi se na str. 63 na kojoj se navodi pjesma srpskog pjesnika Jovana Jovanovića Zmaja „Šta volim“, koja kroz svaki stih u prvom licu nabraja što lirski 
subjekt voli: npr. „Volim zvezdu kad zablista, volim reku kad je čista...“ da bi zadnji stih glasio „Volim svoju domovinu“. Nabrajanje svega što voli kreće se od prirode preko srodnika do domovine. Drugi primjer nalazi se na str. 88 gdje se nabraja što je sve ljubav: npr. „Ljubav je kad se vole mama i tata. Ljubav je kad se vole sestra i brat", da bi pretposljednja rečenica glasila „Ljubav je kad se voli otadžbina“. U oba primjera je prema domovini/otadžbini usmjerena semiotička prijelazna aktivnost.

\subsubsection{Zaključne napomene}

Josip Broz Tito u slikovnim prikazima bukvara iz 1965. godine javlja se tri puta, na crnobijelim fotografijama, čime se postiže realističnost i autentičnost. Zauzima istaknutu poziciju u bukvaru (sam početak), i to s dvije fotografije. Kada je u ulozi aktera, vektori su njegove ruke, a cilj su mu djeca. Interakciju s korisnikom ostvaruje kada je u društvu djece (zahtjevi osmijeh), a kada je prikazan na portretima, prisutna je samo ponuda. Prikazan je sa dugačke, srednje i bliske udaljenosti, a dosljedno iz prednjeg horizontalnog kuta („On je dio vašeg svijeta“) i vertikalnog na razini oka (,On je kao i ti“). Izbor garderobe prati kontekst fotografije, pa se u odijelu pojavljuje na slici s djecom, kao i na službenom predsjedničkom portretu, dok je u uniformi na slici koja ilustrira test u kojem se spominje rat. Kao društveni akter u jezičnim sadržajima nominiran je formalno svojim punim imenom i prezimenom, uz predsjedničku funkciju (Josip Broz Tito, predsjednik Socijalističke Federativne Republike Jugoslavije). Neformalno se pojavljuje pod službenim nadimkom - Tito, uz koji se često javlja i posvojna zamjenica naš, koju prati i uzajamno pripadanje npr. „Mi smo Titovi, Tito je naš“. Dobno je klasificiran kao najstariji u armiji, smatra ga se stvaraocem armije. Sudjeluje u materijalnim aktivnostima npr. ratovati, štititi, mahati, smiješiti se, iz čega zaključujemo da ga se prikazuje kao ratnika, zaštitnika i osobu koju ljudi posebno vole i uvažavaju, te ga pozdravljaju mahanjem koje on uzvraća sa osmijehom.

U bukvaru iz 1974. Tito je također prikazan na početku bukvara - ovoga puta na fotografiji u boji - te još jednom na slici poštanske marke (crno-bijela tehnika). U društvu djece zadržava ulogu aktera koji za cilj ima djecu. Interakciju sa čitaocem ne ostvaruje direktnim pogledom, prisutna je ponuda udružena sa osmijehom. Kada je sa djecom, prikazuje se sa dugačke udaljenosti, a na portretu sa bliske. Izbor horizontalnog $i$ vertikalnog kuta ostaje isti, pa ga i ovdje vidimo kao sastavni dio svijeta korisnika bukvara i predstavlja mu se kao osoba jednaka njemu. Odjeća nastavlja pratiti kontekst, tj. na neki način ga uvjetovati. Kada je Tito u uniformi, 
djeca su također u uniformama - pionirskim, što ih čini njemu podređenima na hijerarhijskoj ljestvici. U jezičnim sadržajima ga se naziva njegovim službenim nadimkom Tito, uz koji se dodaje imenica drug, koja ga približava čitaocu i izjednačava s njime. Gradacijski, kako bukvar odmiče prema kraju, tako Tito od vrhovnog komandanta i druga postaje dijete, vršnjak čitaoca bukvara i javlja se kao mali Joža (dobna klasifikacija i neformalna nominacija). Kao društveni akter najaktivniji je kao dijete i tu ga opisuju materijalne aktivnosti koje se odnose na tjelesnu aktivnost: sanjkanje, jurnjava, trčkaranje i sl., a od semiotičkih prisutni su glagoli voljeti i strepjeti. Izbor anegdota iz Titovog djetinjstva, koje ga karakteriziraju kao nestašnog i domišljatog, približava predsjednika države korisniku izjednačavajući ga s njim, spuštajući ga na razinu sedmogodišnjeg djeteta.

Promjenom društvenih okolnosti u prvoj polovici devedesetih godina prošlog stoljeća, u kojima je prestala postojati SFRJ, iz bukvara nestaje Josip Broz Tito, ali ulaze Vuk Stefanović Karadžić i Sveti Sava. U bukvaru iz 1996. Karadžićev portret nalazi se na mjestu koje je ranije pripadalo Titu - na samom početku. Prikazan je dva puta slikom, jednom slikarskim portretom (početak bukvara), a drugi put crtežom. Kada uspostavlja interakciju s korisnikom, gleda ga direktno (zahtjev) uz ozbiljan izraz lica, čime traži poštovanje i uvažavanje. Ozbiljan izraz lica prati i ponuda, iz čega se zaključuje da Vuk Karadžić kao reformator jezika očekuje ozbiljnost od korisnika. Ne prikazuje se dosljedno iz prednjeg horizontalnog kuta, jer se u jednom primjeru daje iz djelomično kosog kuta, budući da ipak pripada prošlosti. Vertikalni kut je uvijek na razini oka, što ga čini jednakim čitaocu u smislu odnosa moći. Izbor garderobe ni kod Vuka Karadžića nije slučajan jer se dosljedno javlja prikazan u starijoj dobi, s dugačkim sijedim brkovima i crvenim fesom na glavi, koji čini vezu sa narodom, tradicijom i naposljetku njegovim poslom prikupljanja narodnih umotvorina. Starija životna dob ukazuje na golemo iskustvo i mudrost, a istovremeno izaziva poštovanje i uspostavlja autoritet. U jezičnim sadržajima, susrećemo ga pod njegovom punim imenom i prezimenom (formalna nominacija), ali i samo imenom Vuk. Kroz društvene aktivnosti u kojima sudjeluje (materijalne prijelazne i semiotičke prijelazne), prikazan je kao sakupljač narodnih pjesama, priča, zagonetki i poslovica, a htio je opismeniti ljude.

Sveti Sava ne javlja se likom u bukvaru iz 1996. godine, prisutan je samo u jezičnom dijelu gdje se opisuje događaj u kojem nadmudruje učenike uz pomoć lukavstva otkrivši tko je kradljivac meda. On je ovdje u ulozi učitelja (funkcionalizacija), a naziva ga se formalno, kanonski Sveti Sava. Od društvenih aktivnosti, sudjeluje u materijalnim prijelaznima, pronaći kradljivca, uzviknuti đacima. 
U bukvaru iz 2011. godine slikovni prikazi Vuka Karadžića i Svetog Save su zastupljenije. Vuk Karadžić zadržava svoju poziciju na početku bukvara, ali i na početku drugog dijela bukvara od kojeg počinju tekstovi za uvježbavanje čitanja. Susreće ga se i na jednom crtežu, na kojem je zajedno s djecom koja uče slova. Prikazan je kroz dva različita slikarska portreta: prvi se javlja na početku bukvara, na kojemu je u poznim godinama, sijedih brkova, sa crvenim fesom na glavi. Na drugom je prikazan kao mlad čovjek odjeven po građanskoj modi svoga vremena. Oba su prikazana sa srednje udaljenosti, iz prednjeg horizontalnog kuta i vertikalnog na razini oka. Dodatno ga korisniku približava okrugli okvir koji podsjeća na stare uokvirene obiteljske fotografije. Na crtežu je Vuk Karadžić u ulozi reaktera gledajući učenike koji su prikazani iz blagog visokog vertikalnog kuta koji ovdje čitaocu daje poziciju moći (može vidjeti isto što i Vuk koji nadgleda njihovo pisanje).

Sveti Sava se likom javlja u bukvaru iz 2011. godine, i to prikazom portreta s freske iz manastira Mileševa. Srednjom udaljenošću, prednjim horizontalnim kutom i vertikalnim na razni oka ostvaruje bliskost s korisnikom bukvara i čini dio njegovog svijeta bez uspostavljanja odnosa moći. Freska iz manastira Mileševa nije slučajan izbor, budući da su se upravo u tom manastiru čuvale Savine mošti sve do 1594. godine kada ih Turci spaljuju. Kada usporedimo izostajanje lika Svetog Save u bukvaru iz 1996. godine i i prikaz s freske u bukvaru iz 2011. godine možemo zaključiti da ovaj izbor prati jačanje Srpske pravoslavne crkve, koja postaje društveno utjecajnija. I Vuk Karadžić i Sveti Sava javljaju se u identičnim jezičnim sadržajima u bukvaru iz 1996. i 2011. godine.

Analiza je pokazala da ni Vuk Karadžić ni Sveti Sava kao akteri s korisnikom bukvara ne ostvaruju bliskost kakvu je postizao i u slikovnim i jezičnim prikazima Josip Broz Tito. U akcijskim procesima djeca su Titov cilj, prisvaja ga se i potom spušta na razinu djeteta, dok Vuk Karadžić i Sveti Sava izostavljanjem iz akcijskih procesa uspostavljaju nastavnički autoritet i tražeći od korisnika na prvom mjestu poštovanje i uvažavanje, ali nikad ljubav.

Kroz analizu prikaza domovine - posredno preko analitičkih reperezentacija, potom slika pionira, gorana, državnih simbola i sl. - vidimo da se u bukvaru iz 1965. godine domovina poima kroz obnovu i izgradnju u jednu modernu prosperitetnu državu, koju zatim treba braniti i voljeti. U analitičkoj reprezentaciji domovina se obnavlja, gradi i pretvara u modernu državu. Pioniri kao akteri (dječaci i djevojčice) za vektore imaju ruke u kombinacijama sa oružjem, alatima ili olovkama. Ciljevi su im dječaci koji su u igri neprijatelji, pismo koje pišu sa radnih akcija, Titov portret, jelka koju ukrašavaju. Gorani su također dječaci i djevojčice koji sudjeluju u akcijskom procesu koji za vektore, uz ruke, imaju lopatu, stablo, naliv-pero, a ciljevi su im: 
drvo, zemlja u koju će se saditi drvo, bilježnica u koju se zapisuje evidencija posađenih stabala. Armija je prikazana vojnicima, kojima je za cilj Tito, a voze se u tenkovima i otvorenim vojnim vozilima. Ovaj koncept armije spušta se potom na razinu djeteta formiranjem istovjetne dječje armije koju čine djevojčice i dječaci odjeveni u svakodnevnu odjeću, ali oni za oružja imaju metle, lopate, ribičke štapove, dok je cilj kojem streme ipak nevidljiv. Pioniri, gorani i armija prikazuju se sa dugačke udaljenosti kako bi se stekao uvid u raspored elemenata i njihov položaj u prostoru, a odabirom horizontalnog i vertikalnog kuta pripadaju svijetu čitaoca i jednaki su mu. Interakciju direktnim pogledom i osmijehom ostvaruju interakciju s korisnikom (zahtjev) i djevojčice i dječaci, ali ne dosljedno. Jugoslavenska zastava prisutna je u kontekstima vojnih parada, proslave Dana Armije, na radnim akcijama, u rukama ljudi koji dočekuju Tita, a nalazi se i u sklopu analitičke reprezentacije koja prikazuje verziju izgrađene države. Kada je riječ o konceptu domovine u jezičnim dijelovima sadržaja, on je jednostavan - domovina se čuva, brani i voli uz posevizaciju (voli svoju domovinu). Same imenice pioniri, gorani, partizani u sebi sadrže i asimilaciju i funkcionalizaciju, a funkcije se kod pionira dalje dijele na komandire, bolničarke i vojsku. Neka od imena pionira u sebi nose značenja mira i života, npr. Čedomir, Ljubomir, Živan, što je u duhu poslijeratnog perioda. S druge strane, dječaci koji su asimilirani imenicom neprijatelj, nemaju imena. Pioniri se identificiraju emocijom radosti (Pioniri su veseli) i klasificiraju kao mlada vojska Titova. Partizani i armija su posevizirani posvojnom zamjenicom naš, s tim da je armija i na neki način povratno prisvojena jer se pojedinac izjednačava s njom (Armija - to smo mi svi). Pioniri dominantno sudjeluju u materijalnim prijelaznim vrstama aktivnosti koje se odnose na ratovanje (čekati neprijatelja, komandovati), radne akcije (rušiti stijene, nasipati rupe), ukrašavanje škole za državni praznik, a materijalne aktivnosti također su karakteristične i za gorane koji su pak usmjereniji prema sadnji drveća (saditi šumu, donositi borove), što im je i bila osnovna zadaća.

U bukvaru iz 1974. ne susrećemo neposredni slikovni prikaz domovine poput analitičke reprezentacije kakvu smo imali u bukvaru iz 1996. godine. Istovjetno i prikazi partizana izostaju, ali ovaj put i gorana. Prisutni su pioniri, armija i zastava u nekoj varijaciji. Pionire susrećemo kao aktere, djevojčice i dječake, koji za vektore osim ruku imaju bubnjarske palice i dirigentsku palicu. Oni su Titov cilj u akcijskim procesima, a njihovi ciljevi su povezani s glazbom (bubanj i dječak koji svira klavir) budući da ih vidimo u kontekstu svečanosti primanja u pionire. Vojska se prikazuje također kroz aktere koji su ovdje pilot, vojnik i padobranac, njihovi su vektori i u jednom primjeru truba, a ciljevi su shodno ulogama komande $\mathrm{u}$ helikopteru, zastava i tlo. Sredstva su padobran i puške. Interakciju sa čitaocem vojska ne ostvaruje (ponuda), a pioniri tek sporadično. Direktni pogled i osmijeh (zahtjev) korisniku 
upućuju i dječak i djevojčica, ali je odsustvo zahtjeva učestalije, budući da pioniri imaju zatvorene oči od trenutka primanja u pionire, što tumačimo zanosom, ali i povjerenjem. I pioniri i vojska su dani sa srednje ili dugačke udaljenosti, ali dosljedno iz prednjeg horizontalnog kuta i vertikalnog na razini oka, što ih svrstava u svakodnevicu korisnika bukvara i izjednačava ih $\mathrm{s}$ njime. Individualnost pionira - u smislu različitih crta lica jer ipak nose pionirske uniforme prikazana je samo na autentičnoj fotografiji s Titom, a na crtežima su sva djeca gotovo ista, što doprinosi niskoj modalnosti. Kod analize modalnosti uočena je zanimljiva paralela i jedinstvo na relaciji partizani - pioniri - JNA budući da su pionirske kape prilikom svečanosti primanja u pionire zelene, a ne plave boje. Dakle, svaki pionir je potomak nekog partizana i u budućnosti može postati Titov vojnik. Zastava je u bukvaru iz 1974. godine manje prisutna u klasičnom obliku: susrećemo boje zastave koji ukrašavaju okvir pjesama i to u kombinacijama boja plava, bijela, crvena te crvena, bijela, plava. Zvijezda petokraka na zastavama koje se nalaze na topovima, brodovima i helikopteru nije uvijek prisutna. Partizani, vojska i pioniri već u samim svojim nazivima imaju funkcionalizaciju i asimilaciju. Partizani se opisno vezuju za pojam mladosti partizani - zeleni jablani, a partizanke uz vitkost, tjelesno se identificiraju: partizanke - omorike tanke. Iz vojske se izdvaja pilot, koji je klasificiran hrabrošću, a iz pionirske zajednice dječaci Bora i Brana, čija imena semantički znače borbu i obranu. Pioniri se identificiraju emocijom ponosa, a klasificiraju se tjelesno ili dobno pridjevom maleni. Zastava se opjevava u pjesmi na način da joj se pridaju osobine iz prirode, uspoređuje se sa morem, gradom itd. Čak i tridesetak godina od završetka Drugog svjetskog rata, domovinu i dalje treba braniti, ali se ovdje ipak navodi se niz neoružanih sredstava kojima se to čini npr. knjigom, pjesmom, brigom, brašnom, časti, znanjem itd. Da bismo mogli braniti domovinu trebamo biti obrazovani, suosjećajni, brižni, vrijedni, časni itd.

U bukvaru iz 1996. godine, koji nastaje nakon razdruživanja SFRJ-a, nestaju pioniri, gorani, armija, partizani, ali nema ni novih državnih simbola. Unatoč tomu što se promijenila i država i društveno uređenje, novih vizualnih naznaka u bukvaru nema. Domovina se slikovno prikazuje samo na način da se izjednačava sa prirodom, i to u jednom akcijskom procesu gdje djevojčica pruža ruke drveću, svijeću, cjelokupnoj prirodi - domovini, što saznajemo iz teksta pjesme koji slika ilustrira. Domovina je zapravo izjednačena sa planetom Zemljom i onim što čini život na njoj. Naziv države spominje se samo jednom, kada se Beograd izdvaja kao glavni grad Jugoslavije. Beograd je tada bio glavni grad Savezne Republike Jugoslavije, koju su činile Srbija i Crna Gora. 
Bukvar iz 2011. godine ne sadrži slikovni prikaz domovine, niti državne simbole, a kada je riječ o jezičnom sadržaju riječ domovina, odnosno otadžbina prisutna je u dvije pjesme u kojima se nabraja što se sve voli ili što je sve ljubav da bi se na kraju navela i ljubav. Možemo zaključiti da je u poslijeratnim godinama domovinu trebalo graditi i braniti, pa i voljeti, a od devedesetih godina na ovamo se ona izjednačava sa planetom Zemljom, smješta u kontekst svih drugih ljubavi, prema prirodnim ljepotama, ali i bliskim ljudima.

\section{Rodni i međugeneracijski odnosi}

Ovaj dio poglavlja bavi se rodnim i međugeneracijskim odnosima likova prikazanih na slikama u bukvarima. Prvo se analiziraju slikovni i tekstualni prikazi djevojčica (koje se na slikama pojavljuju same ili u grupi) po uobičajenom obrascu. Na isti su način prikazani dječaci, a potom i dječaci i djevojčice u zajedničkim situacijama - bilo u interakciji bilo samo u zajedničkom pojavljivanju. Na kraju se analiziraju međugeneracijski odnosi kroz obiteljske veze s posebnim osvrtom na sve kombinacije odnosa koje postoje ili ne postoje (npr. majka i sin, majka i kćerka, djed i unuka itd.), a rezultati analize slikovnih i jezičnih sadržaja sumirani su u tabelarnim prikazima.

\subsection{Samostalni prikazi djevojčica}

\subsubsection{Analiza slikovnog sadržaja u bukvaru iz 1965. godine}

Djevojčice koje nisu u interakciji s dječacima ili odraslim osobama prikazane su na svega tri stranice bukvara: djevojčica se igra s lutkom (slika 20.), maše lastavici (Mitić 1965: 58) i četiri djevojčice koje su prijateljice (slika 21.). U svim prikazima riječ je o akcijskim procesima, dakle djevojčice su akteri. Vektori su ovdje ruke te ruka u kombinaciji s maramom, koja je ujedno i sredstvo kojim djevojčica maše lastavici. Ciljevi su lutka i lastavica.

Kada analiziramo ostvarivanje interakcije s promatračem, zahtjev je ostvaren na slici koja ilustrira tekst pod naslovom Đurđine drugarice (slika 21), gdje sve četiri djevojčice upućuju direktan pogled korisniku bukvara. Kod odabira plana, u dva primjera je dana dugačka udaljenost (slika 20.), a u jednom srednja udaljenost (slika 21), čime se ne ostvaruje naročita bliskost sa promatračem. S druge strane, uključenost se ostvaruje odabirom prednjeg horizontalnog kuta, koji npr. na slici 20. odašalje poruku „i ti se ovako igraš“ , dok odnosa moći nema jer je vertikalni kut na razini oka. 
Modalnost je na svim slikama niska budući da je bukvar ilustriran jednostavnim crtežima ustaljenog spektra boja, često bez detaljnijeg prikaza okruženja, dubine, detalja i slično. Na Slici 21. pozadina potpuno izostaje, pa nam je nepoznat kontekst - promatrač ne zna igra li se djevojčica u sobi ili u dvorištu. Njezina odjeća odaje da u igri preuzima ulogu majke, ima radnu pregaču oko pasa i uspavljuje lutku u kolijevci kao što majka uspavljuje dijete. Radnu pregaču također ima djevojčica koja maše lastavici (Mitić 1965: 58), što ukazuje na bavljenje kućanskim poslovima.

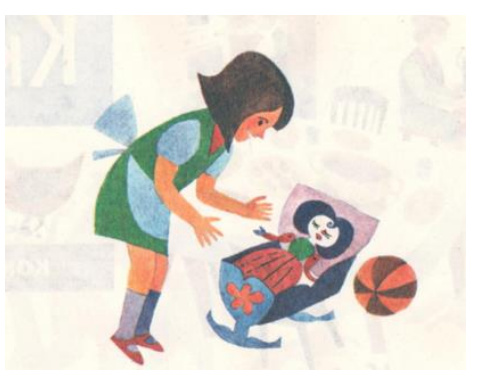

Slika 20. (preuzeto iz Mitić 1965.)

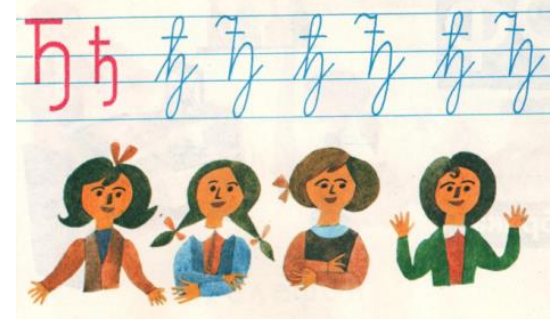

Slika 21. (preuzeto iz Mitić 1965.)

\subsubsection{Analiza jezičnog sadržaja u bukvaru iz 1965. godine}

Djevojčice su kao društveni akteri imenovane poluformalnom nominacijom zastupljenošću imena Kaja, Lela $i$ Đurđina, ali susrećemo i formalnu nominaciju punim imenom i prezimenom: Hristina Đorđević, Ognjenka Đaković, Kaća Ćirić. Relacijski su identificirane kao Đurđinine drugarice. Prisutan je jedan primjer funkcionalizacije gdje se djevojčice nalaze u ulozi učenica i dodatno su određene kao odlične učenice (Mitić 1965: 101). U istom primjeru, kada su dobno klasificirane kao djevojčice, dodatno su određene pridjevom dobre. Ovim je istaknuta njihova vrlina - one su dobre djevojčice, znači da su poslušne i da se pristojno vladaju.

\subsubsection{Analiza slikovnog sadržaja u bukvaru iz 1974. godine}

Prisutnost djevojčica koje nisu u interakciji s dječacima ili odraslim osobama u ovom bukvaru nije ništa veća u odnosu na bukvar iz 1965. godine. Nalaze se na svega dvije stranice bukvara i ovdje ćemo ih prikazati na slici 22 i slici 23. Slika 23 predstavlja cijelu jednu stranicu bukvara, koja kroz četiri slikovna prikaza daje nešto drugačiju verziju bajke o Crvenkapici. U ovoj slikovnoj bajci Crvenkapica poleti uz pomoć ptica, umjesto da nju i baku pojede vuk i na kraju spasi lovac. U oba prikaza na kojima su djevojčice same riječ je o narativnim reprezentacijama: djevojčica kao Crvenkapica je akter, dok su dvije djevojčice na Slici 23 interakteri jer su jedna drugoj cilj. Crvenkapici su cilj cvijet i vuk, za sredstvo ima ptice koje joj daju krila. Interakcija direktnim pogledom (zahtjev) prisutna je samo kod Crvenkapice, i to u jednom slučaju, dok su 
na ostalim slikama prikazane ponude. U svim situacijama djevojčice su prezentirane s dugačke udaljenosti, čime se ne ostvaruje bliskost s korisnikom, ali se ona nadoknađuje upotrebom prednjeg horizontalnog kuta i vertikalnog na razini oka. Jedini izuzetak kod vertikalnog kuta posljednji je crtež u okviru slike 22, gdje je Crvenkapica dana iz djelomičnog visokog vertikalnog kuta, dok je donji dio slike koji čini većinu prikazan iz potpunog visokog vertikalnog kuta. Korisniku je na taj način dana mogućnost da vidi isto što i Crvenkapica koja leti, ali da opet ne uspostavi potpunu moć nad njom.

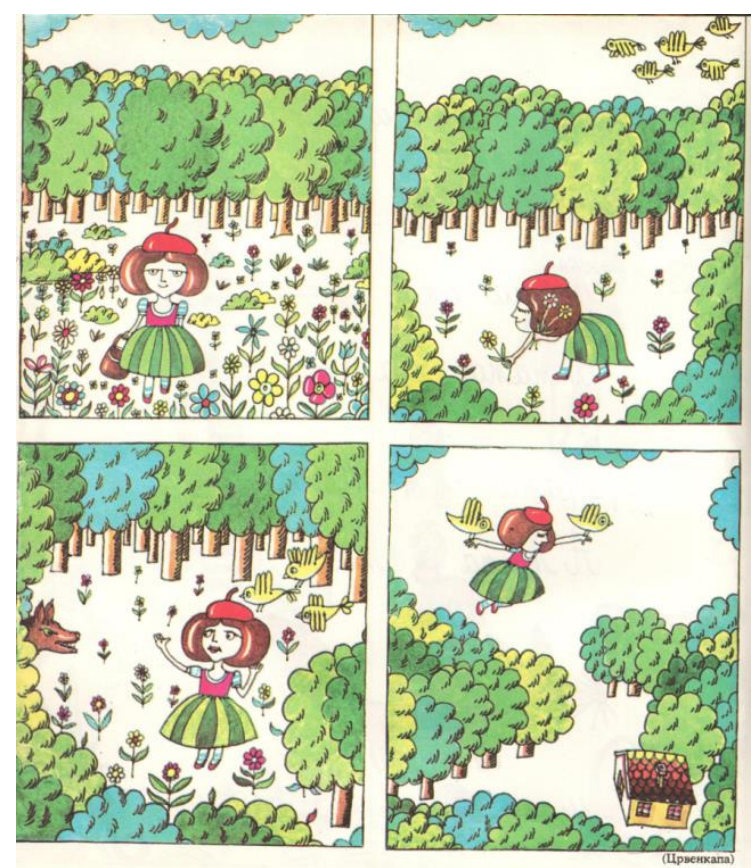

Slika 22. (Preuzeto iz Janjušević, Milardić, Timotijević 1974.)

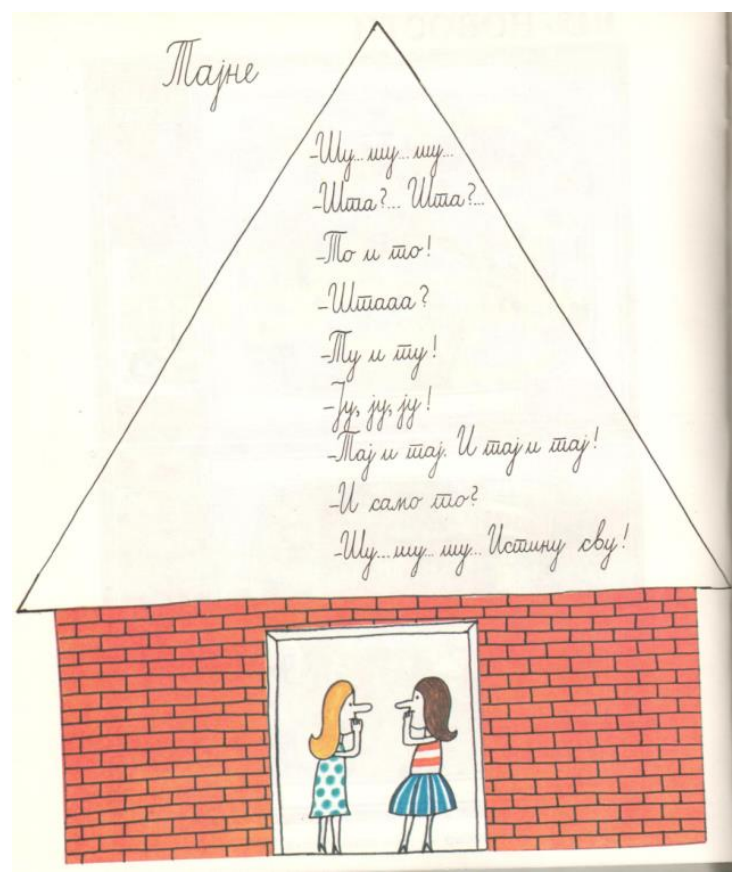


Slika 23. (Preuzeto iz Janjušević, Milardić, Timotijević 1974.)

U cijelom bukvaru iz 1974. godine modalnost je niska jer su crteži jednostavni, često nemaju pozadinu, dubinu, prikazane detalje i ni približno ne imitiraju realističnost. Kada obratimo pažnju na odjeću, djevojčice i dalje nose suknje i haljine, imaju dugu kosu i međusobno se posebno ne razlikuju.

\subsubsection{Analiza jezičnog sadržaja u bukvaru iz 1974. godine}

Kada su djevojčice prisutne u ulozi društvenih aktera, samo su nominirane, i to poluformalno imenima Ana i Gordana. Kada sudjeluju u društvenoj aktivnosti, to je materijalna prijelazna aktivnost: praviti (tortu), tražiti (savjet), umijesiti (tortu), a za semiotičku prijelaznu aktivnost postoji samo jedan primjer, i to negirani glagol sviđati, koji se odnosi na recepte za tortu koje djevojčici daju razne životinje i nijedan joj ne odgovara.

\subsubsection{Analiza slikovnog sadržaja u bukvaru iz 1996. godine}

Djevojčice koje se prikazuju same ili u grupi u bukvaru su iz 1996. godine malo zastupljenije u odnosu na bukvare iz 1965. i 1974. godine, a njihovi se prikazi javljaju na šest stranica. U jednom primjeru djevojčica je dio konceptualne reprezentacije (slika 24), dok se u svim ostalima pojavljuje u sklopu narativnih reprezentacija u kojima je i akter, cilj, ali i pratnja. Kada je u ulozi aktera, vektor čini njezina ruka, u kojoj je najčešće jedan ili više cvjetova. Ciljevi kojima stremi su cvijeće, krletka s pticom, druga djevojčica i leptir. Interakciju s korisnikom bukvara ostvaruje dosljedno direktnim pogledom koji je udružen sa nizom emocija od osmijeha preko snuždenosti do brige. Djevojčice su prikazane dosljedno na dugačkoj ili srednjoj udaljenosti, a kada je riječ o izboru kuta, to su uvijek horizontalni prednji i vertikalni na razini oka, što znači da one pripadaju našem svijetu i da nema iskazanog odnosa moći između korisnika bukvara i prikazanih aktera. Modalnost je dosljedno niska, pa tako vidimo odsustvo prikaza konteksta i pozadinskih sadržaja. Djevojčice izgledaju isto, $\mathrm{s}$ predimenzioniranom dugačkom kosom svezanom u rep i velikim cvjetovima u kosi. Ovdje treba spomenuti da su autori na str. 78, na kojoj je ilustracija pjesme o djetetu i leptiru, odlučili prikazati djevojčicu sa cvijećem, iako pjesma spominje samo dijete ne navodeći mu spol. Igra s leptirom i ruža u ruci prema tradicionalnim predodžbama više pristaju djevojčici nego dječaku. 
Slika 24 prikazuje djevojčicu u okviru konceptualne reprezentacije, a ovdje je to analitički proces. Cjelinu čini slovo „A“, koje je prikazano u gornjem dijelu, dok su ispod dijelovi - u ovom primjeru predmeti i bića koji počinju prvim slovom azbuke, a među njima je i djevojčica Ana. Ona ostvaruje interakciju s korisnikom bukvara, upućuje mu direktan pogled i blagi osmijeh (zahtjev) sa srednje udaljenosti, iz prednjeg horizontalnog kuta i vertikalnoga na razini $o k a$. Vizura potpuno pripada korisnikovu svijetu i djevojčica traži da joj se uzvrati osmjeh. Potpuno pripada našem svijetu, jednaka je nama i traži da joj se uzvrati osmijeh. Kao i sve djevojčice, i ona ima veliki cvijet u kosi koji je vrlo čest motiv i u bukvaru iz 1996. godine. Modalnost ni po čemu ne odudara od onoga što je gore navedeno.

Slika 25 pripada narativnim reprezentacijama, ali ovdje je po prvi put u prikazu djevojčica prisutan verbalni proces. Na dnu stranice dani su dijaloški oblačići, koji su tako pozicionirani vjerojatno iz razloga što gornji dio stranice zauzima tekst, pa ne bi stali na očekivano mjesto iznad glava govornika. Sve tri djevojčice prikazane su na srednjoj udaljenosti, iz horizontalnog prednjeg kuta i vertikalnog na razini oka. Pripadaju korisnikovu svijetu, ne uspostavljajući odnos moći, ali traže interakciju i da im se uzvrati emocija. Raspon emocija se ovdje kreće od ljutnje i direktnog pogleda kod prve djevojčice s lijeve strane, koja prstom pokazuje na sebe (,Ja se ljutim, razumjet ćeš me“), preko širokog osmijeha s direktnim pogledom kod djevojčice u sredini, do zadovoljnog izraza lica i direktnog pogleda kod djevojčice na kraju. Modalnost je ovdje također niska, bez pozadine, detalja, dubine, a uz zaštitni znak velikih cvjetova u kosama djevojčica.

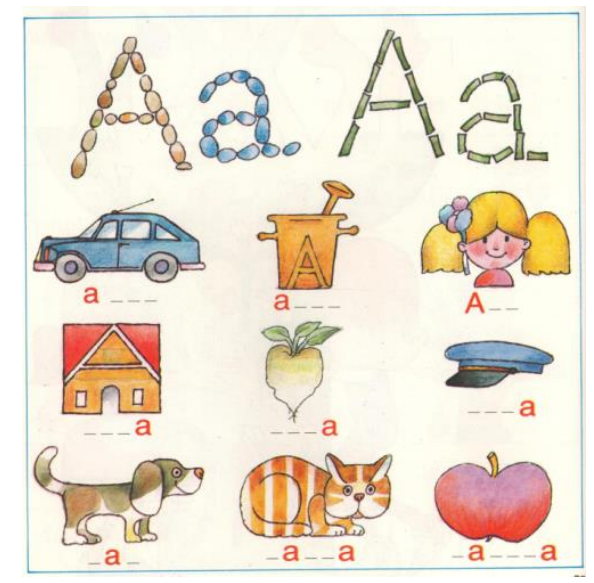

Slika 24. (preuzeto iz Milatović, Ivković 1996.)

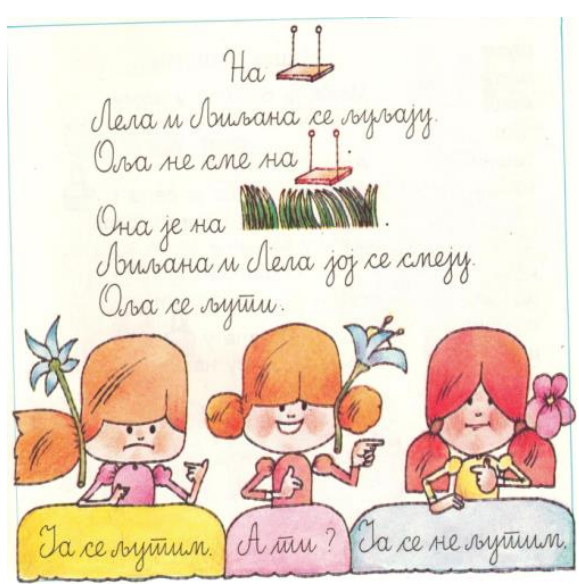

Slika 25. (preuzeto iz Milatović, Ivković, 1996.) 


\subsubsection{Analiza jezičnog sadržaja u bukvaru iz 1996. godine}

Kad su djevojčice u ulozi društvenih aktera nominirane su polu-formalno, samo imenima, i to: Ana, Lela, Ljiljana, Olja, Sanja. Dobno su identificirane već upotrebom imenice djevojčice, dok relacijske ili tjelesne identifikacije izostaju. Kada sudjeluju u društvenim aktivnostima, to je materijalna prijelazna aktivnost $\mathrm{u}$ primjeru ljuljati se, materijalna prijelazna interaktivna $\mathrm{u}$ primjerima: smijati se (drugoj djevojčici), kazati (majci), pustiti (pticu) i semiotička prijelazna: ljutiti se (na drugu djevojčicu), slušati (pjesmu ptice).

\subsubsection{Analiza slikovnog sadržaja u bukvaru iz 2011. godine}

Najmanju zastupljenost slikovnih prikaza djevojčica koje su same ili u grupi utvrdili smo u bukvaru iz 2011. godine - na dvije slike (slike 26 i 27). U oba primjera prisutne su konceptualne reprezentacije u kojima je dan analitički proces. Na slici 26 cjelinu čini slika koja je dana gore i nju izdvojenu možemo promatrati kao narativnu reprezentaciju u kojoj je djevojčica akter, njezine ruke i šake vektori, s time da je cilj ovdje nevidljiv. Dijelovi su prikazani u donjem dijelu slike, gdje su slikovni prikazi životinja iz zoološkog vrta umetnuti u tekst umjesto riječi. Djevojčica je dana na srednjoj udaljenosti, ostvaruje kontakt direktnim pogledom i pripadnost našem svijetu iskazana je uobičajenim horizontalnim prednjim kutom i vertikalnim na razini oka. Analizom modalnosti vidimo da je prikaz zoološkog vrta ovdje nerealan, jer su sve životinje prikazane zajedno, pa tako majmun sjedi slonu na leđima, tigar i zebra su jedno pored drugoga itd. Pretpostavka je da se išlo u pravcu komičnosti, ali i ekonomičnosti u smislu da što više životinja stane na sliku.

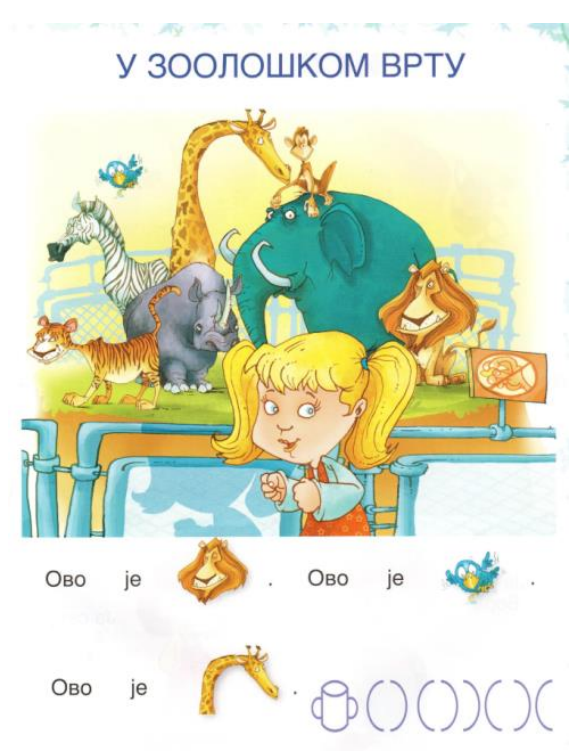

(Slika 26. Preuzeto iz Milatović, Ivković 2011.) 
Slika 27 također pripada konceptualnim reprezentacijama i čini preslikan model slike $24 \mathrm{uz}$ nešto drugačiji izbor ilustracija slova. Djevojčica Ana ovdje je isto dio analitičkog procesa gdje je prikazana među predmetima i bićima koji u svojim riječima sadrže slovo „a“. Dana je na srednjoj udaljenosti, iz prednjeg horizontalnog kuta i vertikalnog na razini oka, dok interakcija direktnim pogledom izostaje. Za razliku od slike 24 ovdje nema zahtjeva, nego ponuda uz osmijeh. Modalnost je također niska i djevojčica već neizostavno ima dugačku kosu svezanu u dva repa, obučena je u ružičasto uklapajući se u dosadašnji stereotip djevojčice.

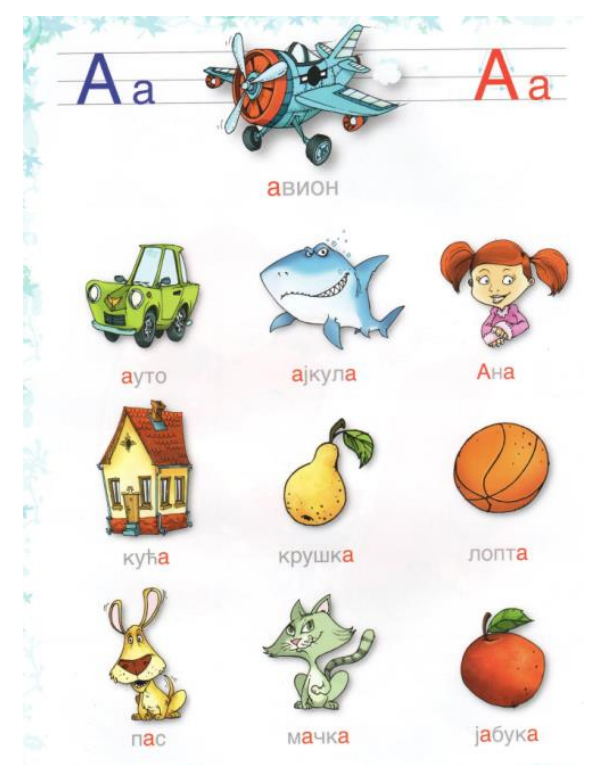

(Slika 27. Preuzeto iz Milatović, Ivković 2011.)

\subsubsection{Analiza jezičnog sadržaja u bukvaru iz 2011. godine}

Kada su djevojčice prikazane kao društveni akteri, imenovane su samo polu-formalno i ovdje su prisutna gotovo ista imena kao i u prethodnom bukvaru: Ana, Lela, Ljiljana i Olja. Djevojčice sudjeluju u materijalnoj neprijelaznoj aktivnosti (ljuljati se) i semiotičkoj prijelaznoj: smijati se (drugoj djevojčici), ljutiti se (na drugu djevojčicu).

\subsection{Samostalni prikazi dječaka}

\subsubsection{Analiza slikovnog sadržaja u bukvaru iz 1965. godine}

Zastupljenost dječaka u odnosu na djevojčice nedvojbeno je nadmoćna jer su prisutni na 23 stranice bukvara. Inače, bukvar iz 1965. godine dosljedan je u narativnim reprezentacijama, pa su i dječaci dio akcijskih procesa uz jedan izuzetak stranice 47 na kojoj se pojavljuje mentalni 
proces. Dakle, dominiraju akcijski procesi u kojima je dječak glavni akter s nizom vektora $\mathrm{u}$ kombinaciji s rukom: igla i konac (zašiva poderanu loptu), klip kukuruza, konopac, klupko, ruka i noga, nalivpero, sendvič, štap za pecanje, telefonska slušalica. Ciljevi kojima dječaci streme jesu: bilježnica, drugi dječaci, drvo, golubovi, kobila i ždrijebe, kuća, lopta, mačka, pas, raketa, riba, sendvič, svinja, vol, zmaj od papira. Dječaci imaju i veći raspon sredstava koja se koriste u akcijskom procesu: avion, frula, kanta za ribu, štap za pecanje. U situacijama u kojima postoji pratnja, za dječaka je to pas.

Kod ostvarivanja interakcije pogledom s korisnikom zastupljeni su ponuda, zahtjev $\mathrm{u}$ kombinaciji s osmjehom i sam zahtjev u vidu samo direktnog pogleda prema korisniku. Odabran je prednji horizontalni kut koji odašalje poruku da je prikazan dio svijeta kojem pripada korisnik bukvara. Vertikalni kut dominantno je na razini oka kod kojeg nema odnosa moći, uz jedan izuzetak na slici dječaka koji piše „kalendar prirode“ (Mitić 1965: 75). Tu je korisnik u poziciji moći je je upotrijebljen visoki vertikalni kut. Korisniku je dana mogućnost kontrole i nadzora pisanja svog vršnjaka iz bukvara.

S obzirom na to da je modalnost ujednačena kroz čitav bukvar, jer ga i stilski određuje, ona je ovdje također niska. Ilustracije su jednostavni crteži uz oskudan prikaz okruženja, ograničenog spektra boja, ali uz interesantne razlike vidljive u odjeći dječaka iz grada i sela. Gradski dječaci nose kape šilterice i cipele (Slika 29), dok su djeca u ruralnim krajevima gologlava, sa šajkačama na glavi ili šeširima za rad u polju (Slika 28). Prsluk, kao ostatak elementa narodne nošnje, također je često prisutan u selu. Npr. dječak koji se ljulja na grani na Slici 28 na sebi ima dugačku bijelu košulju, dugačke bijele hlače i prsluk - svo troje su osnovni elementi jednostavne narodne nošnje. Isti dječak je bos, što je također specifično za selo, dok djeca u gradskim sredinama uvijek nose cipele.

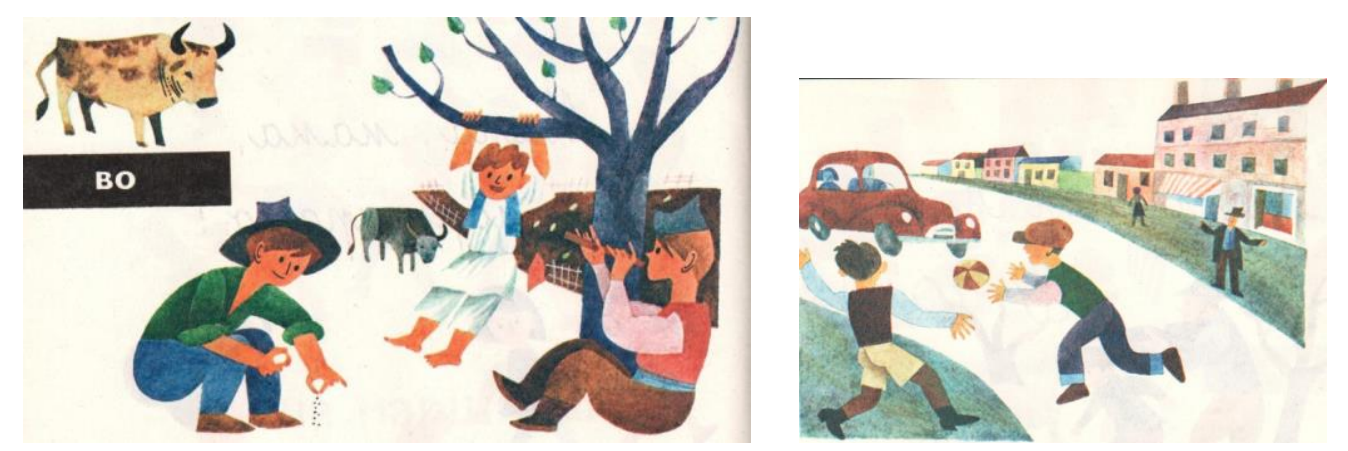

(Slika 28. Preuzeto iz Mitić 1965.)

(Slika 29. Preuzeto iz Mitić 1965.) 


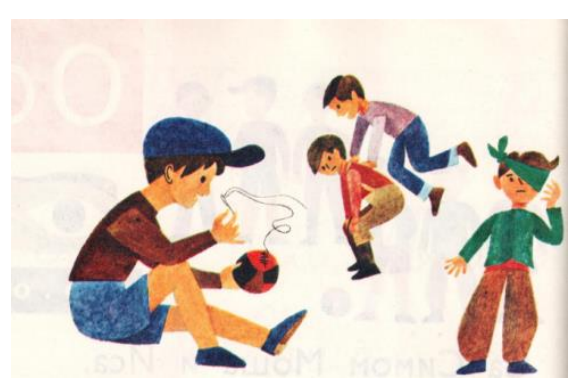

(Slika 30. Preuzeto iz Mitić 1965.)

\subsubsection{Analiza jezičnog sadržaja u bukvaru iz 1965. godine}

Dječak u ulozi društvenog aktera nominiran je polu-formalno i tu je prisutan niz muških imena i nadimaka: Časlav, Čeda, Dragan, Đorđe, Filip, Gaja, Gojko, Isa, Kosta, Lune, Milan, Miša, Moma, Nemanja, Ognjen, Pavle, Saša, Sima, Srđan, Uroš, Vesa, Zoran, Žarko. Postupak funkcionalizacije također je primijenjen, pa su dječaci određeni kao sportaši, učenici $i$ đaci.

Kada sudjeluju u društvenoj aktivnosti to je najčešće materijalna prijelazna instrumentalna aktivnost: izgubiti (užinu), ne jesti (užinu), nositi (užinu u ruci), staviti (užinu u torbu), načiniti (lađice), ponijeti (kukuruz) bacati (kamen), spuštati (u vodu), pronaći (lopatu), trčati (za lađicom), spotaknuti se (o panj), natočiti (vodu), ići (u školu), prati (zube), napraviti (golubarnik), puštati (zmaja), pružati (zob), sašiti (loptu), imati (golubove), mrviti (mravima sir) zasaditi (drveće), naletjeti (na auto), ustaviti (auto). Npr. Đorđe je izgubio svoju užinu; Ponijeli Nemanja i Ognjen svinjama kukuruz i usput razgovaraju; Đorđe je trčao za svojom lađicom. Spotaknuo se o panj i pao u potočić; Sava mrvi mravima sir.

Materijalna neprijelazna aktivnost prisutna je u znatno manje primjera: doručkovati, letjeti, klizati, sanjkati se, sjesti, sići, skijati, stajati, trčati, umoriti, visjeti, svirati. Npr. Posle toga doručkujem; Vasa svira.; Momir visi.

Materijalnu prijelaznu interaktivnu aktivnost susrećemo u primjerima: doći (kod drugog dječaka) gledati (lađicu, pravac kretanja, utakmicu) javiti se (drugom dječaku), loptati (Loptali se Lune i Pavle na putu), pitati (jedan dječak drugoga), prići (drugom dječaku), rvati se (dječaci jedan s drugim), saviti (uho drugom dječaku), srušiti (drugog dječaka), rugati se (jedan dječak drugome). Npr. Uroš i Vesa se rvu, Uroš srušio Vesu; Rugao se Đorđe Srđanu; Dođi da gledamo na televiziji prijenos fudbalske utakmice. 
Semiotička neprijelazna aktivnost prisutna je u svega dva glagola htjeti i snivati (avion: Uroš sniva avion), usnuti (prijatelje; Usnio sam Nešu, Evu i Nevenu), a semiotička prijelazna aktivnost u primjerima razgovarati (dječaci jedan s drugim), upitati (drugog dječaka), reći (dječaku), primijetiti. Npr. Časlav i Čeda idu u školu i razgovaraju.

\subsubsection{Analiza slikovnog sadržaja u bukvaru iz 1974. godine}

Zastupljenost slikovnih prikaza dječaka koji nisu u interakciji s odraslim osobama ili djevojčicama u bukvaru nije puno veća u odnosu na djevojčice. Prisutni su na svega tri stranice, dok se prikazi samih djevojčica javljaju na dvije stranice. Ovakva situacija nameće logično pitanje - koji su akteri najzastupljeniji u bukvaru iz 1974. godine? Bukvarom dominiraju odrasle osobe izvan obitelji: mornari, fotograf, ribar, šumar, lovac, košarkaši, kuhar, rudar, liječnik, astronaut, muškarci zaposleni u cirkusu, kovač, pilot, mesar i jedno mitsko biće muškog spola - džin. S obzirom na to da nisu u interakciji s dječacima i da ne čine dio obitelji, oni neće biti predmet analize.

Dječaci su ovdje prisutni u okviru akcijskog i verbalnog procesa u kojima je dječak akter, odnosno govornik. Vektori su dosljedno ruke u kombinaciji sa štapom za pecanje i novinama, koje su istovremeno i sredstvo. Cilj su ribe. U ovom bukvaru postoji jedan primjer pojavljivanja dječaka u okviru konceptualne reprezentacije, gdje je prikazan samo glavom u okviru teksta pod naslovom „Kako je Đura uhvatio lava“. Riječ je jednom istom crtežu dječakove glave, koji se u tekstu ponavlja dva puta. On ne ostvaruje interakciju s korisnikom direktnim pogledom, pa je prisutna ponuda - doduše kroz blisku udaljenost koja ga približava korisniku, dok prednji horizontalni kut i vertikalni na razini oka dječaka svrstavaju u korisnikov svijet bez prisutnosti odnosa moći. Dječaci prikazani u primjerima verbalnog (Slika 40) i akcijskog procesa (Slika 41) dani su na širokoj i srednjoj udaljenosti, obojica iz prednjeg horizontalnog kuta i vertikalnog na razini oka. Obojica pripadaju svijetu korisnika bukvara, ne uspostavljaju odnos moći, s time da samo dječak sa šaranima u ruci (Slika 41) ostvaruje interakciju direktnim pogledom udruženim s osmjehom (zahtjev). Modalnost je u oba primjera niska - umjesto pozadine koja bi ponudila informacije o kontekstu i dala dodatne detalje prisutna je samo bjelina zbog koje izostaje i dubina slike. Nema detalja i na svakoj je slici ograničen izbor boja. 


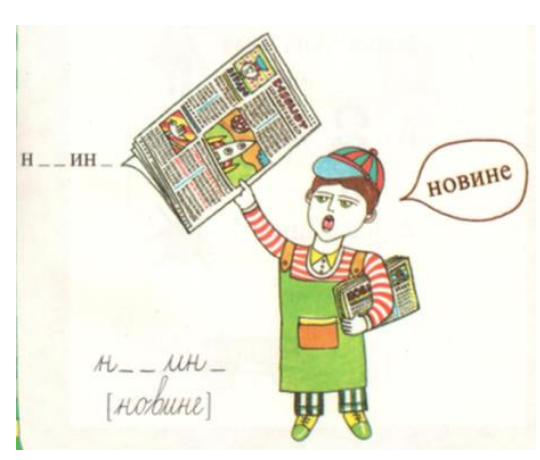

Slika 40. (Preuzeto iz Janjušević, Milardić, Timotijević 1974.)

\section{Раша има 3 шарана.}

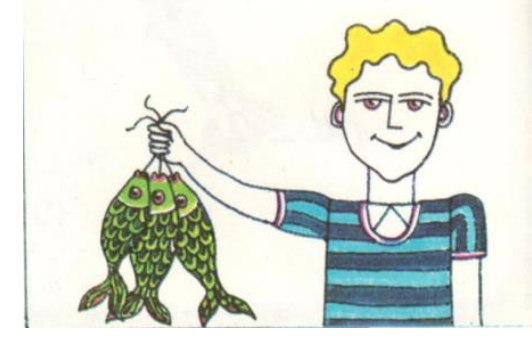

Slika 41. (Preuzeto iz Janjušević, Milardić, Timotijević 1974.)

\subsubsection{Analiza jezičnog sadržaja u bukvaru iz 1974. godine}

Dječak u ulozi društvenog aktera prisutan je samo kroz polu-formalnu nominaciju osobnim imenima Raša i Đura. Kada sudjeluje u društvenoj aktivnosti, to je najčešće materijalna prijelazna instrumentalna aktivnost gdje dječak nešto radi ili posjeduje npr. šarati (šare), imati (olovke i papir), crtati (kuću), napraviti (vrata), postaviti (prozor) i sl.

Valja istaknuti da se u ovom bukvaru ne pojavljuje situacija u kojoj se grupa dječaka zajedno igra, koja je česta u bukvaru iz 1965. godine. Dječak je u ulozi kolportera, ribolovca i posredno lovca („Kako je Đura uhvatio lava“) jer je crtao lava, kojeg je zatvorio u nacrtanu kuću s rešetkama na prozorima.

\subsubsection{Analiza slikovnog sadržaja u bukvaru iz 1996. godine}


Prikaz samoga dječaka u bukvaru iz 1996. godine pojavljuje se na 12 stranica. Prikaza dječaka ima više od broja stranica zbog zastupljenosti takozvanih ,priča u slikama“, gdje aktivnosti dječaka zauzimaju svaku od npr. četiri slike po stranici bukvara. Najzastupljeniji su u narativnim reprezentacijama, dok se u svega nekoliko primjera dječaci pojavljuju $\mathrm{u}$ konceptualnim reprezentacijama.

Kada je riječ o akcijskim procesima, dječak je u njima u ulozi aktera, interaktera i cilja. Kada se pojavljuje kao akter, vektore čine njegove ruke, a ponekad i noge. Ruka u funkciji vektora $\mathrm{u}$ određenim primjerima ima produžetak u vidu nalivpera, konopca kojim je pričvršćen papirnati zmaj, uzda i cvijeća. Ciljevi su: svjećica na torti, papirići na stolu, druga strana ulice, kolut za igru, predimenzionirani puž koji se može i uzjahati, zmaj od papira, dječaci koji su se sakrili, lopta, magarac (koji se također jaše), volan i ptice. Sredstva koja u akcijskim procesima koriste dječaci jesu kolut za igru, romobil i štap, a u ulozi pratnje javlja se pas.

U primjerima verbalnog procesa, govornici su dječaci u grupi, ispod čijih je slika napisan tekst, i dječak u ulozi pekara koji također pored sebe nema klasičan oblačić s tekstom, nego se tekst nalazi napisan pored njega i on ga pokazuje rukom.

U bukvar iz 1996. godine, u okviru prikaza dječaka na str. 71., daje se događaj u slikama u kojem se kroz šest odvojenih slika prikazuju akcijski procesi, ali i pojava, tj. fenomen koji je prisutan u reakcijskim procesima. Priča u slikama pod naslovom „Događaj na ulici“ predstavlja dječake koji igraju nogomet pored prometne ulice, u jednom trenutku lopta pobjegne na cestu i jedan od njih istrči da je dohvati, međutim nesretno padne pod kotače automobila i završi u bolnici. U primjerima događaja reakteri su dječaci, a fenomen je akcijski proces i bolničko vozilo. Jedan od primjera (slika 43.) bit će detaljnije analiziran u okviru posebno izdvojenih slika na kraju ovoga dijela poglavlja.

Dječak je prisutan i u jednom primjeru u sklopu konceptualne reprezentacije, i to kao dio analitičkog procesa (str. 24). Cjelinu čini slika prometa na kojoj se vide ulica i križanje, dok dijelove predstavljaju učesnici u prometu, a jedan od njih je dječak.

Kod ostvarivanje interakcije s korisnikom bukvara dječak se uvijek prikazuje iz srednje ili dugačke udaljenosti. Direktnim pogledom ostvaruje se zahtjev koji je ovdje dodatno pojačan snagom emocije, jer je udružen s osmjehom ili brigom. Prisutna je i ponuda, kod koje izostaje direktan pogled, ali i jedna zanimljiva situacija u kojoj je glavni akter okrenut leđima (slika 42), što će biti posebno analizirano. Dječak svakako pripada svijetu korisnika bukvara i blizak mu je jer se dosljedno prikazuje iz prednjeg horizontalnog kuta i vertikalnog na razini oka. 
Modalnost je i u ovom bukvaru niska jer ne prikazuje okruženje aktera, dubinu, izostaju detalji i boje su svedene na ograničen spektar. Ipak, možemo primijetiti određene osobitosti u vezi s odjećom, ali i razlike u odnosu na bukvar iz 1965. godine. Naime, dječak kad je mali, praktično beba, na glavi ima kapu s pomponom, a kao stariji dječak nosi kapu sa šiltom ili šešir. U bukvaru iz 1965. godine dječaci u gradu nose kapu sa šiltom te su obuveni, dok su oni iz sela bosi i nose odjeću čiji dijelovi čine elemente narodne nošnje. Dječaci su bosonogi u bukvaru iz 1996. godine kada su u situaciji dokolice, kada provode slobodno vrijeme u kojem nije prisutna neka unaprijed zadana igra poput primjerice nogometa. Bosonogost je ovdje pratilac bezbrižnosti, jer dječak nema obuću kada se proteže, vozi romobil, jaše na predimenzioniranom pužu, na kraju bukvara on je raščupane kose, bos i sa cvijećem u rukama - kao da je iznikao iz prirode same.

Slika 42 predstavlja narativnu reprezentaciju u kojoj je dječak akter, sredstvo je romobil, a cilj je nevidljiv. Neuobičajen je njegov prikaz s leđa, što je svakako usamljen primjer u bukvaru, jer na ovaj način ne ostvaruje kontakt s korisnikom bukara. Ipak, ostvaruje se odnos povjerenja, jer leđa okrećemo onome kome vjerujemo, a odabirom horizontalnog prednjeg kuta i vertikalnog na razini oka, on se svrstava u svijet korisnika bukvara. Dječak je dan na širokoj udaljenosti uz izostanak bilo kakvih detalja koji bi pružili dodatne informacije o okruženju u kojem se nalazi. To je jedan od razloga niske modalnosti, koja je npr. detaljima okruženja mogla razjasniti nalazi li se dječak u svom dvorištu, na igralištu, na ulici i slično. Slika nema dubinu, detalje, kontekst, ali s druge strane odabirom odjeće (kapa sa šiltom) kazuje da je riječ o školarcu koji provodi svoje slobodno vrijeme u dokolici (bosonog je).

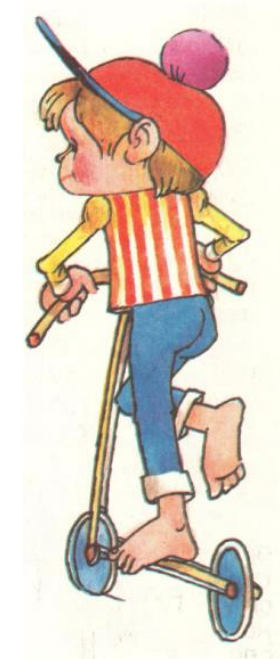

(Slika 42. Preuzeto iz Milatović, Ivković 1996.) 
Na slici 43 vidimo nešto rjeđe prisutnu narativnu reprezentaciju - pojavu, koja je dio reakcijskog procesa. Naime, pojavu, tj. fenomen ovdje predstavlja zapravo akcijski proces, a to je dječak koji tijelom i rukama seže za loptom i udara ga automobil. Analizom akcijskog procesa vidimo da je dječak akter, njegove ruke su vektori, a cilj je lopta. Dječaci koji stoje s desne strane u ulozi promatrača su reakteri. Dječak koji stoji krajnje desno i rukama se prima za glavu svojim pogledom prema dječaku kojeg je udario automobil formira liniju koja funkcionira poput vektora u akcijskom procesu. Plavokosi dječak pored njega pak upućuje direktan pogled korisniku bukvara, čime ostvaruje zahtjev, koji je ovdje udružen s gestom užasa - rukama se prima za glavu, uz izraz brige na licu. On šalje snažnu emotivnu poruku: „O ne, pao je pod auto! To se može desiti i tebi ako si neoprezan“. Direktan pogled upućuje i dječak kojeg udara automobil, što dodatno pojačava lekciju koja se želi prenijeti djetetu koje čita bukvar - „Budi oprezan u igri, ne istrčavaj za loptom, posljedice mogu biti opasne“. Cijela je slika prikazana na širokoj udaljenosti, čime je ostvaren jasan pregled svih aktera i reaktera, a perspektivom iz prednjeg horizontalnog kuta i vertikalnog na razini oka. Događaj je svrstan u svijet kojem pripada i sedmogodišnjak koji se ovim bukvarom opismenjava.

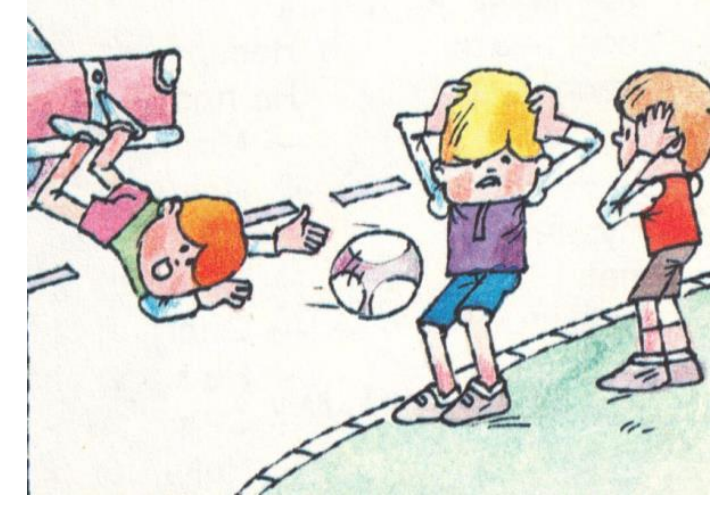

(Slika 43. Preuzeto iz Milatović, Ivković 1996.)

Proveli smo posebnu analizu slike 44 zbog neobičnog izbora elemenata koji je čine, a i paralele koja se na kraju može povući. Dječak na slici dio je akcijskog procesa, on je akter, vektori su njegove ruke i uzde, dok je cilj puž na kojem jaše. Veza ruke-uzde usmjerena je prema pužu, koji je ovdje istovremeno i sredstvo za kretanje. Puž je nerealno velik, sapet uzdama, ima stremene u kojima su dječakova stopala i očito je da igra ulogu konja. Druga dječakova ruka ispružena je u vis i u njoj su dvije predimenzionirane ruže. Slika zapravo donekle ilustrira tekst koji se nalazi krajnje desno, u kojem su riječi rastavljane na slogove, i govori o tome kako se puž sporo penje uz ružu. Dječak je prikazan na širokoj udaljenosti, odabirom prednjeg horizontalnog kuta i vertikalnog na razini oka - smješten je u svijet kojem pripada i korisnik 
bukvara. Zahtjev ovdje izostaje jer akter ne upućuje direktan pogled korisniku, štoviše prikazan je iz profila. Modalnost je očekivano niska jer izostaje okruženje i kontekst, umjesto kojih je na slici samo bjelina. Na slici nema dubine ni detalja, a i sam crtež daje nerealnu i neostvarivu situaciju. Međutim, može se povući paralela između ovakvog prikaza dječaka s poznatim konjaničkim portretima, koje možemo u povijesti umjetnosti pratiti od Tiziana, koji 1548. slika portret Cara Karla V. u bitci za Mühlberg. Na konjaničkim portretima prikazuju se uglavnom vladari. Na slici iz bukvara dječak preuzima ulogu vladara ogrnuvši plašt preko leđa, umjesto konja on jaše puža, a ruže drži u ruci poput mača ili koplja s kojim bi krenuo u bitku. Na samom dnu crteža vide se oblačići od prašine koje puž ipak stvara svojim kretanjem, što znači da njih dvoje naposljetku postižu brzinu potrebnu za uspješno kretanje. Dječak je bos, što govori da ovaj prizor spada u domenu igre i razonode, zapravo u maštariju jer je situacija neostvariva $u$ realnosti.

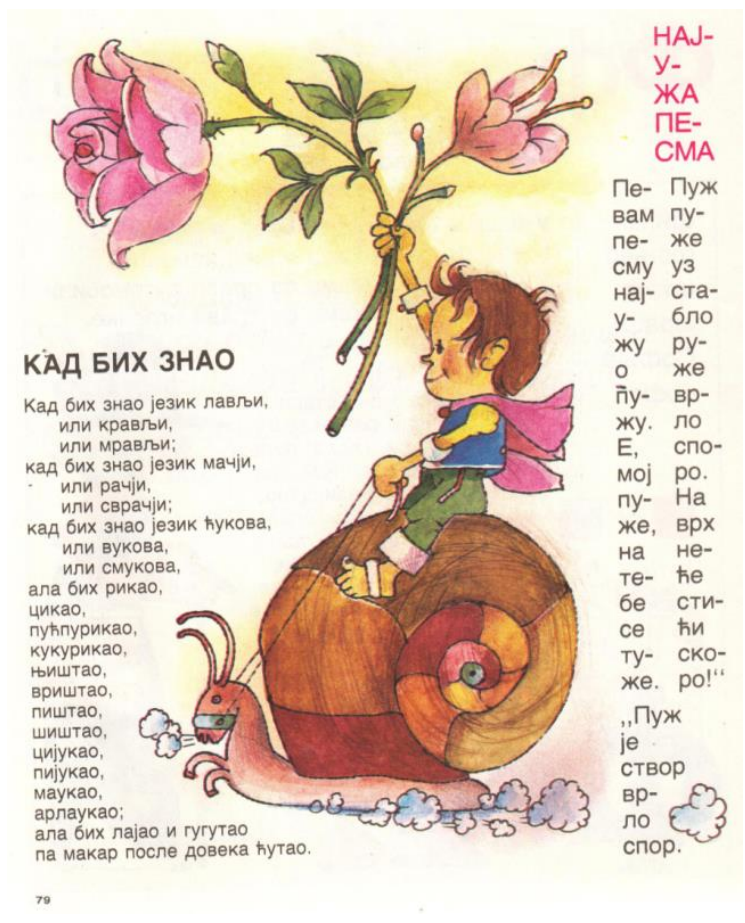

(Slika 44. Preuzeto iz Milatović, Ivković 1996.)

\subsubsection{Analiza jezičnog sadržaja u bukvaru iz 1996. godine}

Kada je dječak u ulozi društvenog aktera, postupak njegovog imenovanja je poluformalna nominacija, pa tako susrećemo imena: Goran, Marko, Mita, Miša, Pavle, Pera, Saša, Toma, Voja, Zoran. Dječaci su dobno, ali i tjelesno identificirani upotrebom pridjeva mali: mali Gliša, 
mali Petar. Susrećemo još i oblik mališani, gdje se dječaci zbirno identificiraju prema uzrastu, ali i prema funkciji-prijatelj i pekar.

Kada dječak sudjeluje u društvenim aktivnostima, a pritom nije u interakciji s djevojčicama ili drugim odraslim akterima, to je najčešće materijalna prijelazna instrumentalna aktivnost: prelaziti (ulicu), krenuti, imati (pušku, krušku, kravatu, školsku torbu, zaprežna kola, vola, hambar sa žitom), napraviti (zmaja), otići (u šumu), umijesiti (hljeb). Manje je primjera materijalne neprijelazne aktivnosti, i to tek u četiri glagola: čekati, otići, voziti, sjediti. Semiotičku prijelaznu aktivnost susrećemo samo u jednom primjeru, „oslušnuo šum u šumi“, dok je semiotička prijelazna prisutna u glagolima nasmiješiti se i ponositi se.

\subsubsection{Analiza slikovnog sadržaja u bukvaru iz 2011. godine}

U bukvaru iz 2011. godine dječacima koji se igraju samostalno ili u grupi zauzimaju 20 stranica bukvara. Samih prikaza ipak je nešto više, jer su i u ovom bukvaru prisutne „priče u slikama“, koje kroz niz slika prikazuju neki događaj. Dječaci su najzastupljeniji u narativnim reprezentacijama, od kojih su najprisutniji akcijski proces, a sporadično reakcijski i mentalni proces. Kada je je dječak akter u akcijskom procesu, vektor čini njegova ruka s nizom predmeta koji su ponekad i u ulozi sredstava: olovka, konopac na kojem je pričvršćen zmaj od papira, knjiga, ruža, kamen, mreža za hvatanje leptira, četkica za zube. U situacijama kada igra nogomet, vektor nerijetko čine noge, pa i čitavo tijelo kojim seže za loptom. Ciljevi u akcijskom procesu jesu: brodić koji se spušta niz vodu, bilježnica, lopta, koš prilikom igranja košarke, papir na kojem se piše pismo, volan automobila, zmaj od papira, ozlijeđeni dječak, kruh (u jednom primjeru ga mijesi jer je u ulozi pekara, u drugom primjeru ga doručkuje), leptir, drugi dječak, ptica, žaba, zubi, škola, lopta. Kada je prisutna pratnja, to je drugi dječak ili pas, a sredstva koja dječak kao akter koristi su knjiga, kamenčić (kojim gađa žabu, slika 45), četkica za zube i olovka.

Kada se dječak nalazi u ulozi reaktera u reakcijskom procesu, pojavu čini knjiga ili drugi dječak. U mentalnim procesima dječak je senser, a pojavu predstavljaju primjerice na str. 106 slike životinja u „oblačiću“. Cijela slika mentalnog procesa zapravo ilustrira pjesmu koja govori o tome kako bi dječak volio govoriti jezikom životinja, pa ih stoga i zamišlja. U drugoj situaciji mentalnog procesa, pojavu čine slike iznad njegove glave koje predstavljaju sve što on doživljava čitajući knjigu (str. 113). 
Znatno je manja zastupljenost konceptualnih reprezentacija u odnosu na narativne. Susrećemo dječaka u okviru analitičkog procesa, i to na način da dijelove čini školski pribor, a cjelinu sam dječak sa otvorenom praznom školskom torbom u koju taj pribor spada (slika 46). Kroz analitički proces daje se i prikaz ispravnog prelaska ulice, koji čini cjelinu, i faze prelaska ulice (čekanje kada je crveno svjetlo na semaforu, prelazak kada je zeleno) koje su dijelovi.

Kada je riječ o odabiru plana, u analitičkim procesima se koristi srednja udaljenost, dok je dugačka najprisutnija u narativnim procesima, što je i logično budući da je radnja najbolje vidljiva s distance te vrste. Kod ostvarivanja interakcije s korisnikom bukvara pogledom, prisutni su i zahtjev i ponuda. Zahtjev je često udružen s osmjehom, npr. kada dječak u ulozi pekara mijesi kruh, leti na ptici, zna sva slova, ide prema školi i osmijehom poziva čitaoca da mu se pridruži. Direktan pogled koji u sebi sadrži zahtjev javlja se i u kombinaciji s pospanim izrazom lica, ali i sa pokretom pranja zubi. Ponuda je s druge strane manje obvezujuća za korisnika bukvara, jer mu akter ne upućuje direktan pogled i ne traži reakciju, čak i kada se javlja u kombinaciji sa osmijehom. Dosljedna upotreba horizontalnog prednjeg kuta i vertikalnog na razini oka sve dječake i situacije u kojima se nalaze i sudjeluju svrstava u svijet korisnika bukvara i čini ih njemu jednakima.

Analiza modalnosti pokazuje da u analitičkim procesima izostaje prikaz okruženja, detalja i pozadine, kao i u situacijama koje su nerealne, npr. dječak se nalazi s unutarnje strane korica bukvara i skriva se iza slova. S druge strane, soba u kojoj se dječak ujutro budi prikazana je s puno detalja. Najvišu modalnost i najviše detalja imaju slike koje služe za opis ili prikazuju okruženje koje je vezano za školu i učenje, npr. knjižnica. Ona se prikazuje s puno više detalja nego priroda koja isto tako čini okruženje nekog akcijskog procesa. S obzirom na to da ovaj bukvar ima iste tekstove poput onoga iz 1996. godine, zanimljivo je pratiti razlike u izboru ilustracije za pjesmu Jovana Jovanovića Zmaja „Dete i leptir“،. Unatoč tomu što pjesma govori o djetetu, ne ističući spol, u bukvaru iz 1996. godine situacija djeteta koje nudi leptiru ružu ilustrirana je odabirom djevojčice, dok je u bukvaru iz 2011. godine umjesto nje prisutan dječak. Elemente narodne nošnje na dječacima, u vidu prsluka i šubare, susrećemo kod ilustracije narodne priče „Rđava šala“. U starijim izdanjima bukvara dječaci iz sela nosili su šešire ili su bili gologlavi, dok su gradski dječaci često imali kape šilterice. U bukvaru iz 2011. godine kapa tog tipa čak prati suvremeni modni izričaj, pa je okrenuta naopako u dvije situacije, na slici koja prikazuje dječaka dok razmišlja (str. 106.) i dok ubrzano raste, pa mu se noge neprirodno izdužuju (str. 112). Kada leti na ptici, kao da je ona avion, ima pilotsku kapu i zaštitne naočale na glavi, uostalom kao i sama ptica koja je tu ne samo sredstvo za letenje nego i kopilot (stranica 
nije numerirana, predstavlja naslovnicu drugog dijela bukvara u kojem su tekstovi za uvježbavanje čitanja).

Slika 45 Pripada narativnim reprezentacijama i prikazuje akcijski proces u kojem je dječak akter. Vektor je njegova ruka, a sredstvo kamen koji drži u šaci. Cilj je žaba smještena preko puta njega na listu koji pluta. Pas je u svojstvu pratnje. Kao i većina akcijskih procesa, i ovaj se daje na širokoj udaljenosti, što omogućava sagledavanje svih elemenata. Pripadnost svijetu korisnika bukvara iskazana je odabirom horizontalnog prednjeg kuta, ali s obzirom na to gdje se nalazi žaba i kako stoji dječak bilo bi logičnije da je i on sam okrenut čitaocu profilom. Ipak, on je prikazan gotovo frontalno (blago je ukošen) iz vertikalnog kuta na razini oka, čime izostaje odnos moći između aktera i korisnika bukvara. Ovdje nema interakcije direktnim pogledom, jer dječak gleda svoj cilj, pa je prisutna ponuda u kombinaciji s blagim osmijehom koji odaje zadovoljstvo igrom. Ova slika pripada skupini gore spomenutih sa višim stupnjem modalnosti jer je dio zadatka u kojem se od učenika traži da opiše događaj na slici.

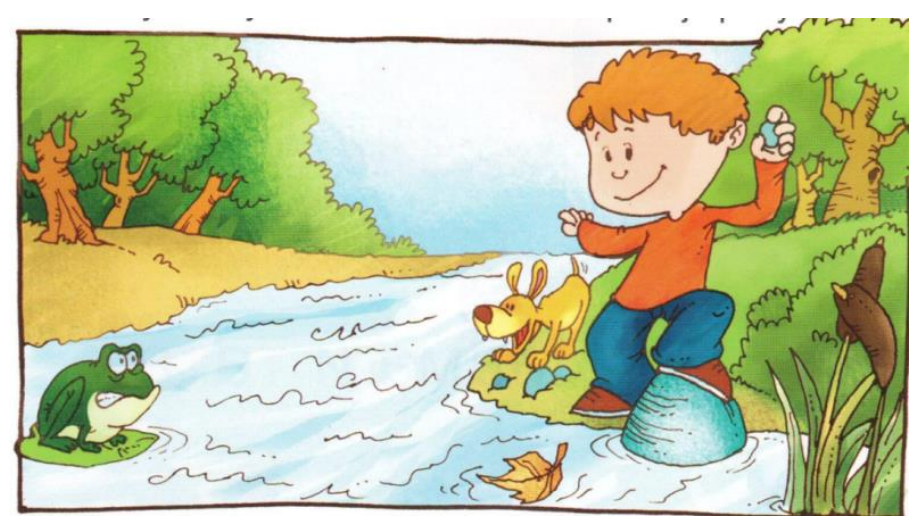

(Slika 45. Preuzeto iz Milatović, Ivković 2011.)

Slika 46 predstavlja konceptualnu reprezentaciju u kojoj je prikazan analitički proces. Podjela je ovdje izvršena prema principu gore/dolje. Školski pribor poput bilježnice, olovke, gumice i ostalog nalazi se u gornjem dijelu slike, i to su dijelovi, a dječak koji je u desnom donjem dijelu slike čini cjelinu. Zapravo, njegova torba je ta cjelina jer u nju treba spremiti sav školski pribor. Ukoliko pažnju usmjerimo samo na dječaka, možemo ga promatrati kao narativni neprijelazni proces u kojem je on akter, ali nema cilj. Dan je sa dugačke udaljenosti, iz prednjeg horizontalnog kuta i vertikalnog na razini oka, što ga svrstava u svijet korisnika i čini ga njemu jednakim. Modalnost je ovdje očekivano niska, jer se crtež nalazi u sklopu analitičkog procesa, pa je sasvim nebitno i okruženje i detalji. 


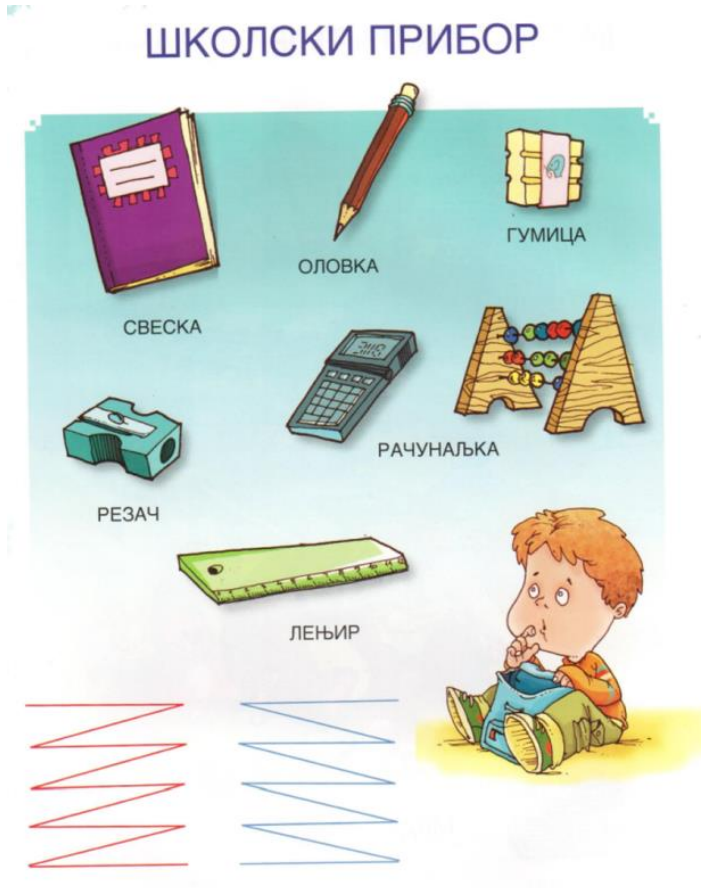

(Slika 46. Preuzeto iz Milatović, Ivković 2011.)

Slika 47 prikazuje klasični akcijski proces s nekoliko aktera i paralelnih radnji. Glavni akter je dječak u prvom planu koji trči za loptom, koja mu je cilj. Vektore čine njegove ruke i noge, a isto je i s akterima iz drugog plana (golman, sudac i dječak kojeg lovi sudac). Lopta je zajednički cilj svima osim sudcu koji pokušava uhvatiti igrača ispred sebe (cilj). Cijeli prizor igre nogometa daje se na dugačkoj udaljenosti, iz prednjeg horizontalnog kuta i vertikalnog na razini oka. Dakle, ovako nogomet igraju i dječaci koji čitaju ovaj bukvar ili odlaze gledati takve utakmice. Zahtjev ovdje izostaje, jer nijedan od aktera ne upućuje direktan pogled korisniku bukvara. Prisutna je ponuda sa zadovoljnim izrazima lica, što govori da je igranje nogometa aktivnost koja donosi zadovoljstvo. Kod analize modalnosti važno je skrenuti pažnju na to kako se udaljavanjem plana gube oštrina i detalji. Najjasnije vidimo dječaka koji trči za loptom, s nešto manje detalja i jasnoće tri aktera iza njega, a najmutnije vidimo publiku. Ipak, oblici aktera u publici dovoljno su jasni da prenesu informaciju o tome da je gledalište rezervirano za muškarce. 


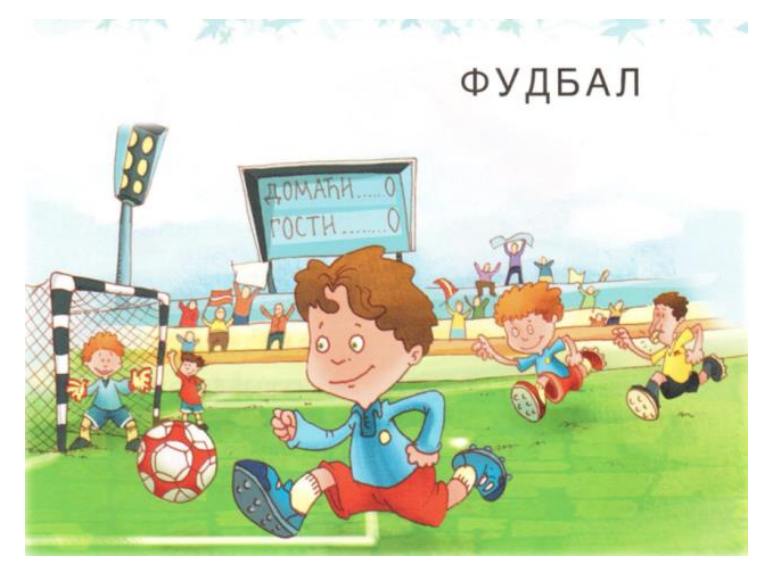

(Slika 47. Preuzeto iz Milatović, Ivković 2011.)

\subsubsection{Analiza jezičnog sadržaja u bukvaru iz 2011 .}

Dječak kao društveni akter u ovom bukvaru nominiran je poluformalno, samo osobnim imenom, a ponekad i nadimkom: Gaša, Gliša, Goran, Marko, Mita, Paja, Pavle, Petar, Toma, Zoran. Dobna klasifikacija koristi se upotrebnom imenice dječak, a tjelesna identifikacija izrazima mališa, mališan. Kada se koristi funkcionalizacija za dječaka, onda su to imenice prijatelj i u jednom slučaju čobanče, što je istovremeno i dobna klasifikacija jer deminutivni oblik upućuje na to da je čobanin zapravo dječak.

Kao sudionici društvenih aktivnosti, dječaci najčešće sudjeluju u materijalnim aktivnostima, dominantno u materijalnim prijelaznim instrumentalnim: baciti (pušku), imati (krušku, kravu, kukuruz, automobile, školsku torbu, gusku, kravatu), izgubiti (dinar), kupiti (pušku), hvatati (ptice), hraniti (ribe), napraviti (zmaja), otići (u šumu), uzeti (dinar), štedjeti (novac).

Prisutni su i u materijalnim prijelaznim interaktivnim aktivnostima, pa susrećemo primjere: poći (u ribolovce), odgovoriti (prolazniku), pomagati (dječaku), smijati se (drugim dječacimačobanima), prevariti (dječak čobanin druge čobane). Sporadični su primjeri materijalne neprijelazne aktivnosti: igrati, lagati, plakati. Dječak plače samo u jednoj situaciji, i to kada je izgubio novac.

Primjeri semiotičke prijelazne aktivnosti jesu: čuti (što rade djeca u susjedstvu), ponositi se (zmajem), spaziti (malu zečju njušku), voljeti (zeca, djevojčicu Ginu), žaliti (zeca). Samo je jedan primjer semiotičke neprijelazne aktivnosti, i to u glagolu misliti: Mislilo da sme lagati u šali. 


\subsection{Djevojčice i dječaci zajedno}

\subsubsection{Analiza slikovnog sadržaja u bukvaru iz 1965. godine}

Djevojčice i djevojčice slikom su prikazani zajedno na 14 stranica. Situacije u kojima dolazi do njihove interakcije najčešće su zadane školskim životom i obavezama: igraju se za vrijeme odmora u školskom dvorištu, nastupaju na školskoj priredbi, ukrašavaju školu za Dan Armije, sade drveće kad su u ulogama pionira, obavljaju dužnosti redara u školi itd. Prilika za druženje izvan škole puno je manje, pa tako posjećuju zoološki vrt, igraju se trgovine, prave snjegovića i, naravno, kao svaka poslijeratna generacija, igraju se rata.

Dječaci kao akteri, prikazani zajedno sa djevojčicama, za vektor imaju ruke u kombinaciji sa mačem, maramom, puškom, pištoljem, štapovima i ukrasnim slovom koje se stavlja na zid. S druge strane, djevojčice za vektor imaju ruke i noge, a u rukama im je cvijeće, ukrasne grančice i spužva. Za dječake su ciljevi: drveni konjić (igračka), lopta, okićena jelka, pas, prozor, sadnica drveta, snjegović, vjeverica, zid. Sredstva koja se koriste za ostvarivanje aktivnosti glazbeni su instrumenti frula i harmonika, pištaljka i štap. Djevojčice kao akteri za cilj imaju: loptu, lutku, okićenu jelku, rupu u zemlji (u koju će se posaditi drvo), sliku na zidu, snjegovića, vijaču, školsku ploču i vjevericu. Djevojčice i dječaci interakteri su samo u situaciji kada plešu kolo. Kada je riječ o pratnji, ovdje je čine i djevojčica i dječak.

Dugačka udaljenost i ovdje je dosljedno upotrijebljena, kao i ostvarivanje interakcije prikazanih aktera sa čitaocem uspostavom prednjeg horizontalnog kuta i vertikalnog na razini oka. Zahtjev je postignut direktnim pogledom koji upućuju i djevojčice i dječaci (sa i bez osmjeha), ali je prisutna i ponuda, kod koje izostaje direktan pogled.

Modalnost je niska u čitavom bukvaru, nevezano uz to što se na slikama prikazuje. Na ovom mjestu treba naglasiti detalj koji se odnosi na odabir garderobe i izgled - ovaj put kod djevojčica: one dosljedno imaju dulju kosu i neizostavno nose suknje ili haljine.

Slika 48. nalazi se među prvim stranicama bukvara i predstavlja učenike na školskom dvorištu za vrijeme odmora. Pripada narativnim reprezentacijama i sastoji se od niza odvojenih akcijskih procesa. Ovdje nećemo svaki pomno analizirati, ali ćemo ih sagledati u cjelini. Radi bolje organizacije i snalaženja u analizi, povući ćemo jednu vertikalnu crvenu liniju od učiteljice, koja je pri vrhu slike, prema dolje. Na taj način smo odvojili lijevu i desnu stranu slike, a ostalo ćemo razdijeliti prema planovima. Prvi plan čine aktivnosti u samom dnu slike, najkrupnije su prikazani i najbliže promatraču - dječaci na klackalici lijevo i tri djevojčice s loptom desno. U drugom planu su djeca koja igraju školice (lijevo) i djevojčice koje preskaču 
vijaču (desno), a u trećem djeca koja plešu kolo (lijevo), dječaci koji guraju kolutove (desno) i učiteljica između njih. Dječaci na klackalici su interakteri, dva nasuprot jednoga. Jedni drugima su cilj, jer poanta igre je pretegnuti drugoga, vektore čine ruke i svaka strana klackalice. Okrenuti su bočno, vidimo ih iz profila, pa izostaje i interakcija pogledom. Desno od njih, djevojčice s loptom su akteri, njihove ruke su vektori, a zajednički cilj im je lopta. S obzirom na položaj ruku djeluje kao da igraju pojednostavljenu verziju odbojke. U drugom planu vidimo i primjer pratnje, lijevo kod igre školice. Dječak i djevojčica koji stoje uz ocrtana polja čine pratnju u prikazanom trenutku. U trećem planu lijevo vidimo tri dječaka i dvije djevojčice kako plešu u kolu držeći se za ruke. Oni su interakteri i baš kolo predstavlja jedinu situaciju u kojoj su dječaci i djevojčice interakteri. Kada je riječ o uspostavljanju interakcije sa korisnikom bukvara, niko od aktera/interaktera prikazanih u akcijskim procesima ne upućuje direktan pogled, pa izostaje zahtjev. Ipak imamo ga u liku učiteljice, koja je zapravo pratnja svim akterima u prikazanim akcijskim procesima. Ona nadgleda igru, ali i direktno gleda korisnika bukvara uz osmjeh ga pozivajući da se pridruži ostalim učenicima u školi. Svi akcijski procesi su dani na širokoj udaljenosti, a odabir kuta svrstava sadržaj u svijet sedmogodišnjaka koji čita bukvar i akteri su jednaki njemu, tako da je tu neizostavno prednji horizontalni kut i vertikalni na razini oka. Osvrnut ćemo se ovdje i na modalnost, iako je u čitavom bukvaru niska, ali pažljivim odabirom detalja kontekstualizira radnju. Dakle, ovdje je modalnost niska jer su sva djeca gotovo ista, vrlo slično odjevena, prevladava ograničen spektar boja (crvena, smeđa, siva, svijetlo plava i crna), nema detalja, dubine i sl. ali je radnja ipak kontekstualizirana. Vidimo ogradu koja opasuje prostor pri vrhu slike, s desne strane je zgrada sa stepeništem i na centriranoj poziciji pri vrhu je učiteljicu koja nadgleda igru. Ta tri detalja nam govore da je to školsko igralište na kojem se djeca igraju za vrijeme odmora. Vidjet ćemo kasnije u analizi slike 49 kako malo informacija može dati okruženje. 


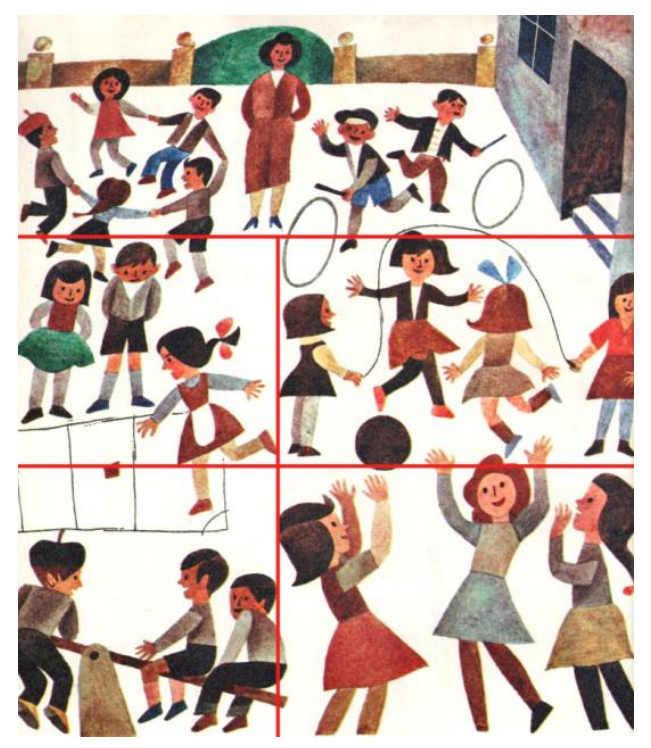

Slika 48. (preuzeto iz Mitić 1965.)

Na slici 49. vidimo jedan od primjera slobodnog vremena provedenog u igri u kojoj učestvuju djeca oba spola. Riječ je narativnoj reprezentaciji, akcijskom procesu. Akteri su ovdje tri dječaka iz prvog plana, vektori su njihove ruke u kombinaciji sa mačem, pištoljem i puškom, koji su ujedno i sredstva. Njihov cilj su dva dječaka iz drugog plana, koji su ovdje u ulozi neprijatelja (slika ilustira tekst pod naslovom „Ljubiša komandir“ u kojem se opisuje igra, str. 85). Djevojčica, koja stoji sasvim desno sa torbom prve pomoći na ramenu, predstavlja pratnju. Budući da je riječ o akcijskom procesu, radnja je prikazana na dugačkoj udaljenosti što nam omogućava jasan pregled svih aktera, a odabir prednjeg horizontalnog kuta događaj smješta u realnost djeteta koje koristi bukvar. Vertikalni kut na razini oka ne uspostavlja odnos moći, čime su prikazani akteri i čitalac bukvara potpuno jednaki. Ipak, dječaci koji se igraju rata ne iniciraju kontakt pogledom sa svojim vršnjakom čitaocem jer kod sve i jednog vidimo samo ропиdu. Kontakt uspostavlja djevojčica. Ona, iako u ulozi pratnje, upućuje direktan pogled (zahtjev) i blagi osmjeh čime šalje poruku: „Mi se ovako igramo i to nas zabavlja.“ Crtež ima nisku modalnost jer su sva djeca gotovo ista, prevladavaju iste ili slične boje, nema detalja, dubine, a ni okruženja koje bi nam moglo više reći o kontekstu igre. Vidimo nešto prirodnog raslinja, ali je nejasno jesu li to mlada stabla ili nešto drugo, a tek sam tekst otkriva da je to šiblje. Jesu li djeca u šumi, u parku ili u nečijem vrtu, isto ne saznajemo. Važnije informacije otkrivaju sami akteri (naoružani dječaci) i njihov cilj, tj. dva dječaka koji se predaju od kojih jedan također ima oružje (pušku), a drugi drži u ruci zastavu koja simbolizira predaju. Slika prikazuje pobjedu nad neprijateljem i to je najistaknutija informacija. 


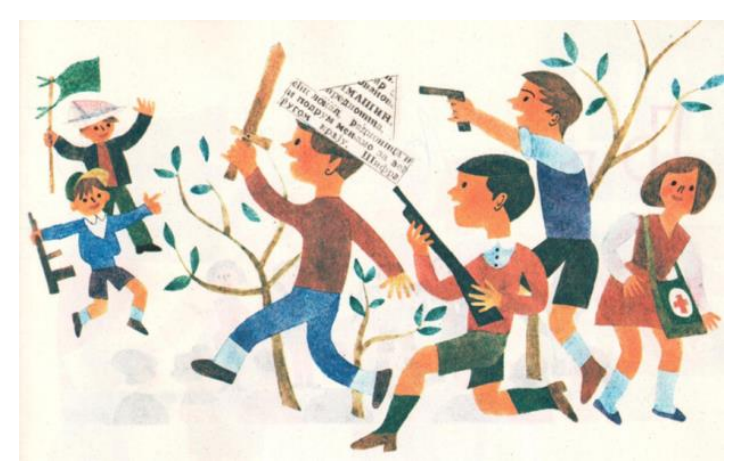

Slika 49. (preuzeto iz Mitić 1965.)

Slika 50. Odnosi se na jednu od gore spomenutih situacija interakcije djevojčica i dječaka u kontekstu zaduženja i školskih obaveza. Oni su ovdje u ulozi redara i ispunjavaju svoje školske zadatke. Slika predstavlja akcijski proces u kojem su i djevojčica i dječak akteri, ali u odvojenim akcijskim procesima. Njezin vektor su ruka i spužva, koja je ujedno i sredstvo, a cilj je ploča koju briše. Njegovi vektori su ruke, a cilj je prozor koji otvara. Čitav prikaz prizora je dan na malo proširenoj srednjoj udaljenosti, jer se akteri vide nešto više ispod razine pojasa, ali opet ne sasvim cijeli da bi to mogla biti široka udaljenost. Ovakva postavka daje jasan uvid u samo aktivnost, njezine elemente i mjesto dešavanja. Iako akteri ne ostvaruju interakciju pogledom s korisnikom bukvara (ponuda), a i prikazani su iz profila, oni pripadaju njegovom svijetu i on se može poistovjetiti sa njihovim obavezama jer su dani u prednjem horizontalnom kutu i vertikalnom na razini oka. Modalnost je niska, budući da učionica ima samo neophodne detalje po kojima se razlikuje od bilo kojeg drugog prostora, a to su ploča i spužva. Sa lijeve strane je prozor, a na centralnoj poziciji na zidu je portret, za koji možemo pretpostaviti da pripada tadašnjem predsjedniku SFRJ, Josipu Brozu Titu. Potvrdu za to nalazimo na str. 78. gdje se u tekstu „Dan Armije“ opisuje kako pioniri ukrašavaju školu „Snežana je zelenilom okitila sliku druga Tita..." Ostatak slike čini bjelina, boje su svedene na nekoliko, nema detalja, dubine i sl. Djevojčica je u već uobičajenoj garderobi i sa standardnom frizurom - suknja i dugačka kosa.

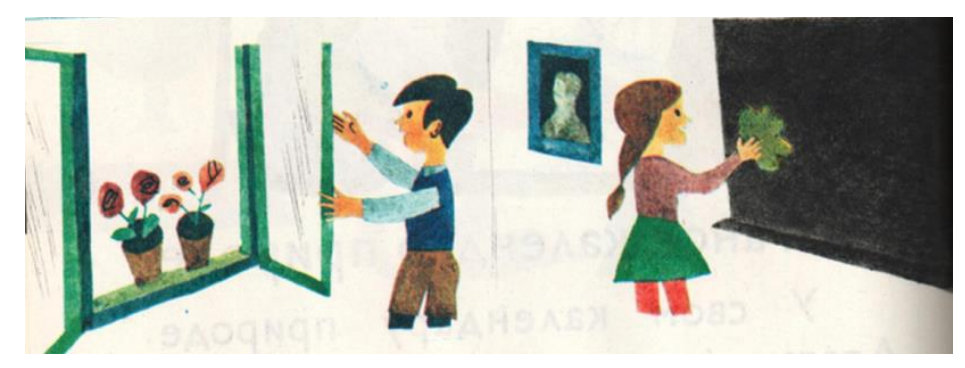

Slika 50. (preuzeto iz Mitić 1965.) 
Na slici 52 prikazana je proslava Dana Armije, koju ilustrira gore spomenuti tekst „Dan Armije“. Ovo je narativna reprezentacija sa nekoliko akcijskih procesa. Dva dječaka sa velikim slovima su akteri kojima su ta slova istovremeno produženi vektori (ruke), ali i sredstva. Cilj im je zid, na koji će slova postaviti. Dječak na ljestvama ima i čekić, koji je također i vektor i sredstvo. Djevojčica za vektore ima ruke i ukrasne grančice, kojima ukrašava sliku na zidu, koja je cilj. Dječak krajnje desno, za vektore ima ruke i zastavu, a cilj mu je zid. Upravo on, držeći zastavu SFRJ, ostvaruje interakciju sa korisnikom bukvara, upućuje mu direktan pogled (zahtjev) i blagi osmjeh. On šalje poruku: „Mi ovako proslavljamo Dan Armije.“ Svi akteri, osim dječaka na ljestvama, prikazani su iz srednje udaljenosti, što ih čini dovoljno bliskima promatraču, a opet daje i jasan pregled svih akcijskih procesa. Budući da su akteri postavljeni u prednji horizontalni kut, ovaj prizor pripada realnosti čitaoca. Vertikalni kut na razini oka izjednačava čitaoca sa akterima i omogućuje mu lako poistovjećivaje sa prikazanim. Modalnost je gotovo identična kao na slici 50. Okruženje je svedeno samo na ključne elemente (ljestve, slika za zidu, zastava), a ostalo je bjelina.

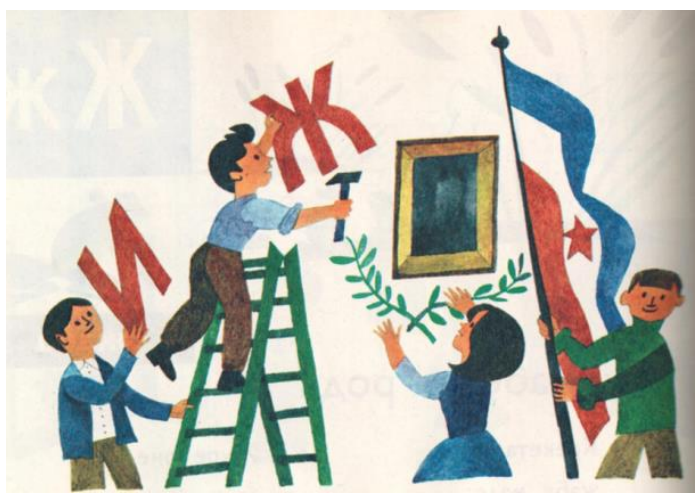

Slika 51. (preuzeto iz Mitić 1965.

\subsubsection{Analiza jezičnog sadržaja u bukvaru iz 1965. godine}

Kada su djevojčice u ulozi društvenih aktera i sudjeluju u zajedničkim aktivnostima sa dječacima nose sljedeća osobna imena (postupak nominacije), od kojih su neka i nadimci: Cana, Janja, Kaća, Ljerka, Ljiljana, Snežana, Sofija. Dječaci su također poluformalno ili neformalno nominirani: Boža, Cvetko, Ćira, Dragan, Filip, Radovan, Žarko, Živan.

Kada je riječ o pridavanju funkcije društvenim akterima, dječaci i djevojčice su pioniri, dječak je prodavac, a djevojčica kupac (igraju se trgovine) i oboje su gorani, kada sade drvo. Postoji 
jedan primjer klasifikacije i to primjeru riječi drugarica, koji ujedno ukazuje i na društveni sustav u kojem je nastao bukvar.

Od materijalnih društvenih aktivnosti u kojima djevojčice i djevojčice sudjeluju timski ili u okviru istog konteksta su materijalne interaktivne i materijalne prijelazne instrumentalne aktivnosti koje su znatno brojnije. Materijalne interaktivne su: igrati se, izvoliti, hvaliti, pjevati, povikati, svirati, učestvovati, gledati. Materijalne prijelazne instrumentalne aktivnosti u kojima podjednako ili zajedno sudjeluju i djevojčice i dječaci su poređati, saditi (šumu, staviti, pjevati i gledati. Dječak u društvu djevojčice sudjeluju u sljedećim aktivnostima: popeo (na ljestve), pruža (slova i eksere), sastavio (parolu), razvio (zastavu), napisao, dok su aktivnosti djevojčice svedene na dva primjera: okitila (sliku) i spustila (drvo). Kod semiotičkih prijelaznih aktivnosti zanimljiva je razlika u radnjama u kojima sudjeluju djevojčice i dječaci. Svi se nalaze u tekstu na str. 95. koji opisuje događaj iz kazališta kada se djevojčice uplaše vuka na sceni: upitati, šaptati, kazati, a dječak ih tješi: Ne bojte se-veli Ćira. Njega će lovac ubiti.

\subsubsection{Analiza slikovnog sadržaja u bukvaru iz 1974. godine}

Djevojčice i dječaci se u ovom bukvaru pojavljuju svega šest puta zajedno, bilo da je riječ o interakciji ili zajedničkom kontekstu. Prisutni su u okviru jedne konceptualne reprezentacije (slika 52), a ostale su narativne prijelazne ili neprijelazne. Oboje su u ulogama aktera, dok je samo djevojčica pratnja. Vektori su uvijek ruke bez dodatnih sredstava poput npr. olovke. Prikazuju se na dugačkoj i srednjoj udaljenosti i oboje upućuju direktan pogled uz osmjeh čitaocu (zahtjev), ali je isto tako prisutna i ponuda, kada izostaje direktan pogled. Oboje pripadaju svijetu korisnika bukvara budući da su dosljedno prikazani iz prednjeg horizontalnog kuta, a odnos moći i ovdje izostaje jer su dani iz vertikalnog kuta koji je na razini oka. Modalnost je niska u čitavom bukvaru, pa tako nisu izuzetak ni zajednički prikazi djevojčica i dječaka. Crteži su jednostavni bez detalja, dubine, perspektive, okruženja umjesto kojeg je najčešće dana bjelina koja ne pruža uvid u kontekst. Djevojčice i ovdje uvijek imaju dugačku kosu, nose suknje i izgledaju poput svojih vršnjakinja u bukvaru iz 1965. godine.

Slika 52 predstavlja konceptualnu reprezentaciju, analitički proces u kojem su djevojčica i dječak prikazani odvojeno, ali prema identičnom modelu - on zauzima prostor lijevo, ona desno, površine na kojima se nalaze posebno su uokvirene i svaka za sebe predstavlja jedan analitički proces. Analizirajući lijevi uokvireni prostor na kojem je dječak, vidimo da je podjela napravljena prema principu gore-dolje. Gornji dio predstavlja cjelinu i nju čini sam dječak, dok 
se donji dio odnosi na dijelove. Dječak je prikazan na dugačkoj udaljenosti, iz prednjeg horizontalnog kuta i vertikalnog na razini oka. On pripada svijetu korisnika bukvara i ne uspostavlja odnos moći nad njim, jednak mu je. Upućuje direktan pogled i osmjehuje se (zahtjev) čime ostvaruje interakciju sa svojim vršnjakom koji gleda ovu stranicu. Dijelove ovdje čine papirnati zmaj, baloni, raketa - svojim kretanjem usmjereni prema gore, i tri aviona koja složno lete kao na vojnoj paradi, ovdje s desne na lijevu stranu. S obzirom na izbor predmeta koji pripadaju dječaku, iščitavamo uloge koje mu se pridaju, pa tako on može biti astronaut, pilot, avanturist i slavljenik. Analizom modalnosti uočavamo da je odjeven u mornarsku majicu, na glavi ima crvenu pionirsku maramu oko vrata i zelenu partizansku ili vojničku kapu sa crvenom petokrakom zvijezdom. Pionirske kape su bile plave, pa izbor zelene šalje jasnu poruku da je dječak budući vojnik, samim tim što avioni na krilima i repu imaju petokrake zvijezde. Dakle, on nije pilot putničkog aviona, nego pilotira u vojnoj avijaciji. Sva četiri predmeta za domet imaju visinu, nebo, stremljenje prema gore što je najizraženije u prikazu rakete, koja ne samo da je okrenuta prema gore nego se iz nje oslobađa gorivo što znači da ona polijeće u svemir. Kao astronaut, on je istovremeno istraživač nepoznatog, ali i znanstvenik. Prostor oko njega ukrašen je vijugavim linijama crvene i narančaste boje, poput plamena što možemo tumačiti simboličnim značenjem strastvenosti, posebno kada usporedimo isti ukras desno oko djevojčice koji je zelene boje. Izbor zelene dodatno uzemljuje i djevojčicu i predmete koji se daju u donjem dijelu slike i pripadaju joj. Predmeti su: lutka, mašna, lopta i torba. Sva četiri nam govore u ulogama koje djevojčica preuzima samim tim što ih posjeduje. Lutka je nalik samoj djevojčici i svrstava se u domenu igara u kojima djevojčica preuzima ulogu majke, mašna je ukrasni odjevni predmet kojim se djevojčica uljepšava, lopta je za igru i torba, koja nije ni školska ni dječja također ju uvodi u svijet odraslih. Poput dječaka, i ona je prikazana na dugačkoj udaljenosti, iz prednjeg horizontalnog kuta i vertikalnoga na razini oka čime je potpuno svrstana u svijet sedmogodišnjeg čitaoca i jednaka mu je. Interakciju ostvaruje direktnim pogledom (zahtjev), ali nije vidljivo nasmijana kao dječak, ona ima jedva primjetan osmjeh koji bi se prije tumačio kao zadovoljan izraz lica. Očekivano je odjevena u suknju i ima dugačku kosu, jagodice su joj naglašene rumenilom, što nije dosljedan postupak u prikazu djevojčica. Ona je našminkana što je također približava svijetu odraslih. Sva četiri predmeta koja joj pripadaju pozicionirana su simetrično i stabilno, kretanje ne postoji pa ni kod lopte, koja je jedina stvar koja ukazuje na dinamičnu igru. Vijugava ukrasna linija u gornjem dijelu slike je izborom zelene boje dodatno povezuje sa prirodom i prirodnim procesima. 


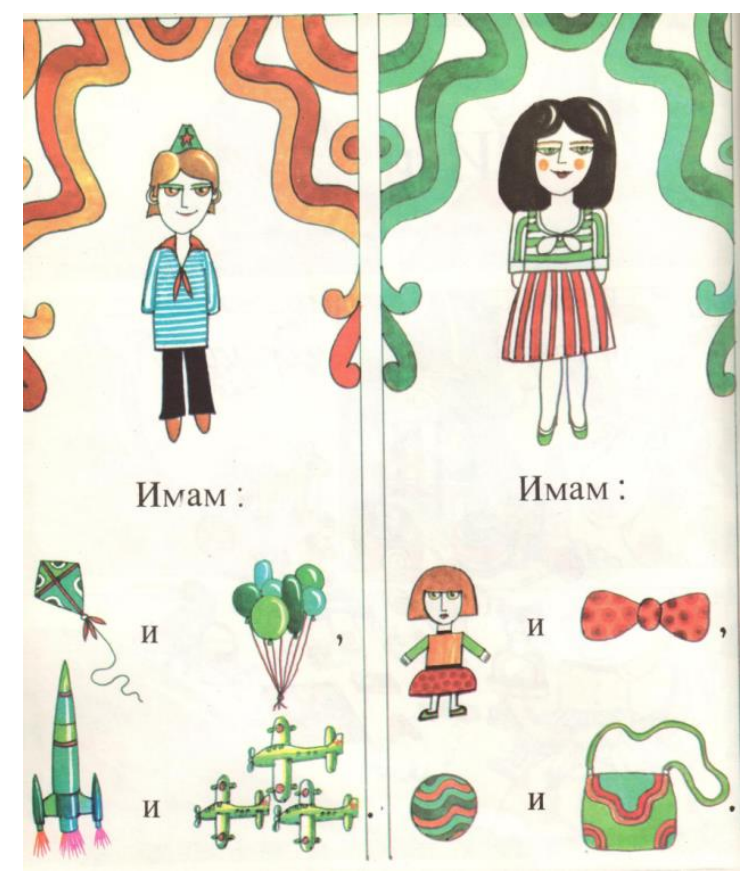

Slika 52. (preuzeto iz Janjušević, Milardić, Timotijević 1974.)

Na slici 53 vidimo pet parova, koje čine djevojčice i dječaci u balonima na čijim košarama pišu njihova imena. Oni su akteri koji sudjeluju u neprijelaznom akcijskom procesu, svi su prikazani na srednjoj udaljenosti, iz horizontalnog prednjeg kuta i vertikalnog na razini oka. Pripadaju svijetu korisnika bukvara, jednaki su mu i upućuju mu direktan pogled u kombinaciji sa osmjehom (zahtjev). Modalnost je uobičajeno niska budući da je ovo jednostavan crtež, sa minimalnim detaljima, okruženja svedenog na krošnje iznad kojih su poletjeli baloni. Ukoliko usporedimo ovaj prikaz djevojčica i dječaka sa ceremonijom primanja u pionire, u prethodnom poglavlju (slike 16 i 17) sličnost je očita. U oba slučaja među njima izostaje bilo kakva interakcija, makar pogledom. Oni samo stoje jedni pored drugih, istih izraza lica, pogleda upućenih čitaocu. Sva djeca izgledaju vrlo slično, djevojčice uobičajeno imaju dugačku kosu i dosljedno se nalaze sa lijeve strane u košarama. 


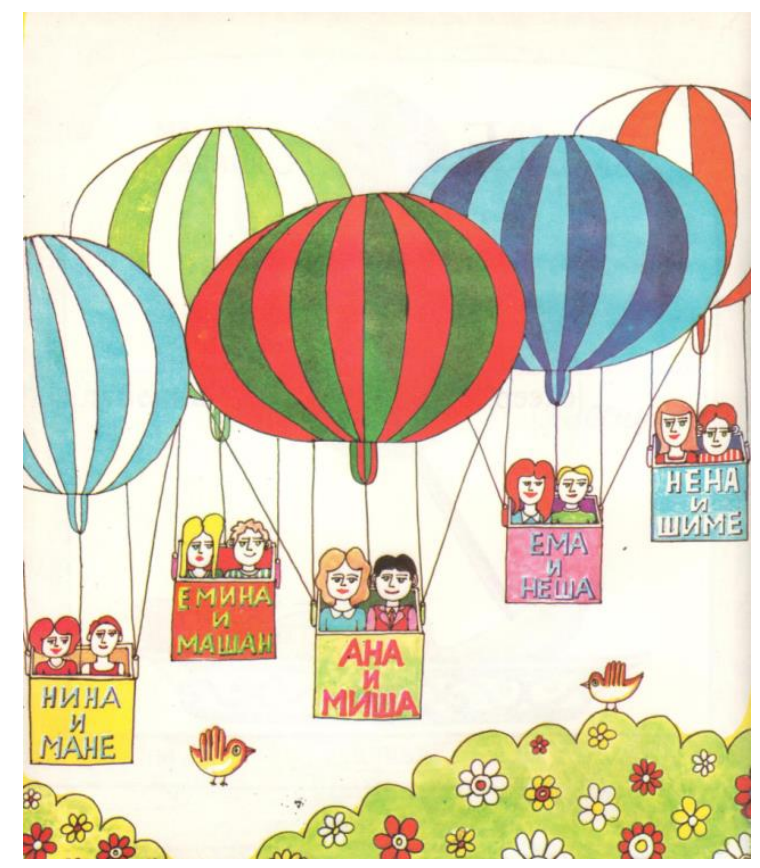

Slika 53. (preuzeto iz Janjušević, Milardić, Timotijević 1974.)

Drugačiji primjer susrećemo na slici 54 koja pripada narativnim reprezentacijama, akcijskom procesu. U ulozi aktera je dječak koji stoji u sredini, vektor je njegova ruka i kao produžetak ispružen kažiprst, dok je cilj dječak sa desne strane. Djevojčica je u ulozi pratnje. Slika inače ilustrira brojalicu „Elem, belem“. Modalnost ne daje nikakve podatke o okruženju i kontekstu, pa ne saznajemo gdje se djeca igraju. Podloga je predstavljena jednom žutom crtom, dok je ostatak bjelina. Djevojčica je neizostavno odjevena u haljinu i ima dugačku kosu.
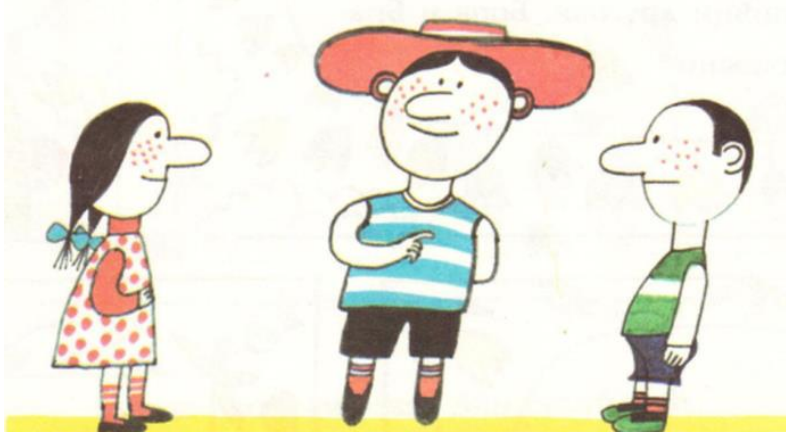

Slika 54. (preuzeto iz Janjušević, Milardić, Timotijević 1974.)

\subsubsection{Analiza jezičnog sadržaja u bukvaru iz 1974. godine}

Dječaci i djevojčice u procesu nominacije kao društveni akteri imaju samo osobna imena što je neformalna nominacija: Ema, Emina, Ivan, Mane, Mašan, Miša, Nana, Neša, Nina, Šime, Vesna. Dječaci sudjeluju u materijalnoj prijelaznoj instrumentalnoj društvenoj aktivnosti npr. 
išao (na vašar). Materijalna interaktivna aktivnost prisutna je također u jednom primjeru: susreo se (sa Vesnom). Npr. Išao Ivan u Varvarin na vašar. U Varvarinu se sreo sa Vesnom.

\subsubsection{Analiza slikovnog sadržaja u bukvaru iz 1996. godine}

Dječaci i djevojčice su zajedno prisutni 17 puta u slikovnim prikazima što je znatno više u odnosu na bukvare iz 1965. i 1974. godine. Najzastupljeniji su u narativnim reprezentacijama, u kojima prvo mjesto zauzimaju akcijski procesi, zatim reakcijski i verbalni procesi. Kada je riječ o konceptualnim reprezentacijama, susrećemo samo analitičke procese u kojima su zajedno prikazani.

Dječak u ulozi aktera u akcijskom procesu za vektore ima ruke, noge i čitavo tijelo. Kao produžetak vektora susrećemo cvijeće, željezničarsku palicu, vesla, spužvu, olovku, naliv-pero, pribor za jelo i lopatu. Ciljevi kojima je usmjeren su: ptica, slova, djevojčica, stablo (penje se na njega), škola, upravljačka palica (kojom vozi vlak), televizor, truba, ozlijeđena ptica, zdrava ptica, rijeka, kantica u pijesku, bilježnica, predimenzionirana stabljika cvijeta, sapun, knjiga, hrana na tanjuru, kompjutor, papir, drugi dječak i djevojčica, grude snijega, snjegović. Za sredstva kod izvršenja akcijskog procesa, dječak ima cvijeće, knjigu, životinje u kavezu zoo vrta, trubu i štap za pecanje. Pranja mu je uvijek djevojčica, bilo da su to dvije djevojčice ili jedna.

Djevojčica u ulozi aktera za vektore, kao i dječak, ima ruke, noge i cijelo tijelo, ali je drugačiji spektar predmeta koji su produžeci vektora. Za djevojčicu su to: cvijeće, žlica, vrč s vodom i štapić, a ciljevi su: ptica, slova, štap štap sa pticom na vrhu koji drži dječak (str.6), stablo koje samo dodiruje, dok se dječak penje na njega (str. 11), igračka medvjedića, knjiga, televizor, harmonika, mikrofon, ptica koju pušta da poleti, lopta, pilići koje hrani, druga djevojčica, kompjuter, snjegović, druga djevojčica i dječak u grupi, grude snijega, snjegović, dječak, jabuka, ptica. Sredstva kojima se služi djevojčica kod ostvarivanja akcijskog procesa su: cvijeće, harmonika, mikrofon, rijeka, kantica u pijesku, ptica, tijesto, predimenzionirana stabljika cvijeta koju grli skupa sa dječakom. Kako je djevojčica dječaku pratnja, tako je i on njoj, ali pratnja joj je i druga djevojčica.

Kada su dječak i djevojčica u ulozi interaktera, vektori su ruke kojima se drže, a cilj su jedno drugome. Ipak, u jednom primjeru na str. 89 oni se drže za ruke, ali u slobodnim rukama imaju cvijeće kojim mašu i cilj im je tunel napravljen od slova. Na taj način, svaki vektor ima drugi 
cilj. Klasična situacija djevojčice i dječaka kao interaktera i ovdje je kolo u kojem se svi naizmjenično drže za ruke i na taj način su povezani.

Verbalni i reakcijski procesi se u ovom bukvaru javljaju znatno rjeđe u odnosu na akcijske procese. Kod verbalnog izostaje dijaloški oblačić i tekst je napisan iznad glava djevojčice i dječaka. Oni se upoznaju i predstavljaju jedno drugome: „Ja sam Bora“, „Ja sam Ana“. U bukvaru iz 1996. godine susrećemo dvije situacije reakcijskih procesa. Reakteri su dječak i djevojčica, a pojava je u jednom primjeru televizijski program koji zajedno gledaju, a u drugom primjeru je to snjegović koji se topi na suncu. Vektori su nastali linijom oka koja kreće od reaktera do same pojave.

Konceptualne reprezentacije prisutne su samo kao analitički procesi i to kroz tri primjera, od kojih će jedan biti posebno analiziran u okviru ovog poglavlja. Dječaci i djevojčice su u sva tri prikazani kao cjelina, a u dijelu strukture koja se odnosi na dijelove razrađeno je npr. ono što im pripada od školskog pribora, životinje u zoo-vrtu koji posjećuju ili elementi koji čine sliku kupanja u rijeci, a sama predstavlja cjelinu (bit će posebno prikazana).

Kada je riječ o ostvarivanju interakcije sa čitaocem bukvara, oboje kombinacijom direktnog pogleda i osmjeha upućuju zahtjev. U jednom primjeru je direktan pogled prisutan u kombinaciji sa donekle zabrinutim izrazom lica kod dječaka (slika 55, dječak koji se penje na drvo). Zahtjev je ponekad udružen i sa pokretom ruke, npr. mahanjem čitaocu ili pokazivanjem određenih predmeta. U izdvojenim primjerima ćemo detaljnije vidjeti neke od situacija $u$ kojima se dodatna interakcija ostvaruje i pokretom ruke. Dječaci i djevojčice prikazani skupa dosljedno su dani sa dugačke udaljenosti, ali iz prednjeg horizontalnog kuta i vertikalnog na razini oka. Ovim postupkom, oni su svrstani u svijet i svakodnevicu čitaoca bukvara i jednaki su mu hijerarhijski, dakle nema uspostavljenog odnosa moći.

Modalanost je u čitavom bukvaru niska, to su jednostavni crteži bez puno detalja, dubine, konteksta itd. Pozadina i detalji se prikazuje samo na slikama koje su u funkciji priča u slikama, dakle od učenika se traži da opiše radnju. S toga ćemo se na modalnost ovdje osvrnuti samo u kontekstu zajedničkog prikazivanja djevojčica i dječaka, gdje su one već tradicionalno odjevene u suknje ili haljine i imaju dugačku kosu. Kada igraju kolo, one imaju cvjetove u rukama, a on na glavi nosi kapu šajkaču koja je element narodne nošnje, uklapa se u kontekst i u odnosu na 1965. predstavlja rijedak detalj ove vrste. Cvijeće koje i dječaci i djevojčice drže u rukama, ili ga one imaju u kosi, često je predimenzionirano. Ovdje ćemo napraviti paralelu sa cvijećem i zelenilom koje je u bukvaru iz 1996. prisutno prilikom polaska u školu, mada je u stvarnosti 
tada jesen i krošnje drveća nisu proljetno zelene boje sa svečanošću primanja $u$ pionire $u$ bukvaru iz 1974. (slike 16 i 17). Na toj svečanosti sve je ukrašeno zelenilom što je proces novog rađanja i stupanja u svijet odraslih, dok se 1996. to isto dešava ali polaskom u prvi razred osnovne škole (slika 55). Dodatnu potvrdu za ovaj zaključak susrećemo u drugom dijelu bukvara u kojem se daju tekstovi za uvježbavanje čitanja. Slika koja uvodi čitaoca u taj dio prikazuje ukrasni luk sačinjen od slova, bogato ukrašen jarkim bojama, prvenstveno zelenom i crvenom, koji nalikuje na kapiju kroz koju će dječak i djevojčica proći držeći se za ruke. Oni na taj način ulaze u svijet odraslih, jer su naučili slova i time za njih počinje nova životna faza (slika 54). Prstima pokazuju slova koja su u luku, čime dodatno ukazuju na važnost ovladavanja vještinom čitanja i pisanja, dok je iznad slike naslov „Sada mogu sve što hoću“ koji dodatno podcrtava poruku.

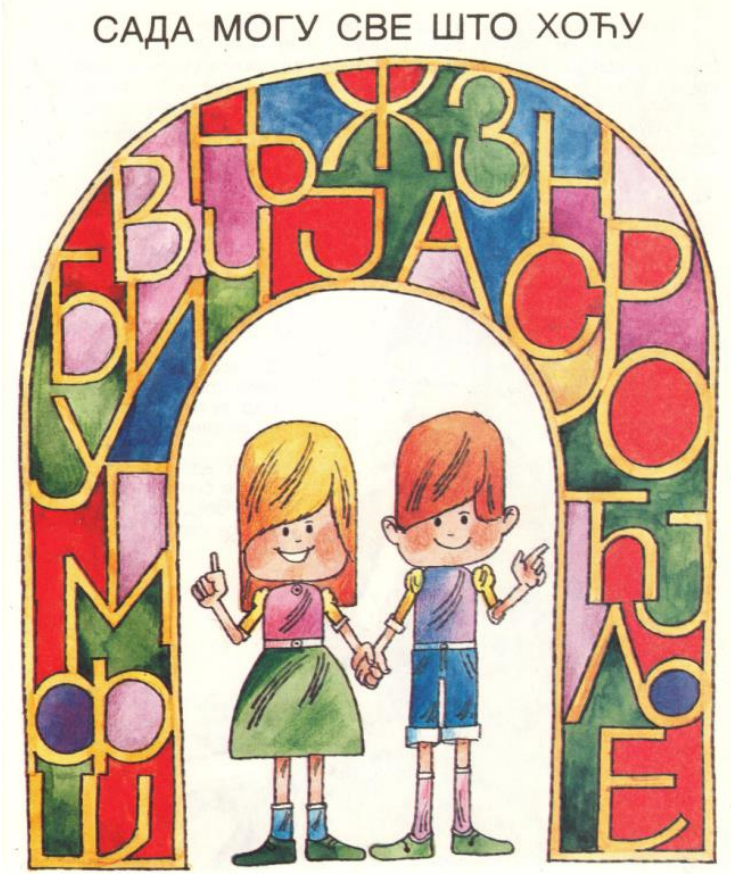

Slika 54. (Preuzeto iz Milatović, Ivković 1996.)

Slika 55 predstavlja sam početak bukvara, polazak u školu i prikazuje dva akcijska procesa. Da bi analiza bila preglednija odvojit ćemo lijevu i desnu stranu slike, odnosno dvije različite radnje i posebno ćemo im pristupiti. Lijevo su dječak i djevojčica u ulozi interaktera (drže se za ruke, jedno drugom su cilj) i sudjeluju u akcijskom procesu. Vektori su ruke kojima drže jedno drugo, ali i druge ruke u kojoj svako od njih ima cvijeće. Cvijeće je ovdje produžetak ruke kao vektora, ali je istovremeno i sredstvo jer njime oboje mašu čitaocu bukvara. Interakciju uspostavljaju direktnim pogledima i osmjehom (zahtjev), ali i mahanjem čitaocu kojeg pozivaju da im se pridruži u školi. Prikazani su na širokoj udaljenosti, iz prednjeg horizontalnog kuta i 
vertikalnog na razini oka, čime su potpuno izjednačeni sa svojim vršnjakom i pripadaju njegovom svijetu i svakodnevici. Dječak i djevojčica na desnoj strani slike su akteri u akcijskom procesu, s tim da se djevojčica za razliku od dječaka ne penje na drvo. Njegovi vektori su i ruke i noge, cilj je stablo koje obuhvaća i rukama i nogama, dok ona jednom rukom (vektor) dodiruje stablo ( $c i l j)$, a druga joj je u zraku i u njoj drži cvijet. Ona poziva čitaoca bukvara i ispruženom rukom pokazuje na krošnju drveta u kojoj je tekst Dušana Radovića „Podržite đaka! Čast đaku! U pobede s đakom! Živeo đak!“ Dakle, đak tj. učenik je neko kome treba podrška, ali postiže pobjede i slavi ga se. Interakciju ostvaruje direktnim pogledom i osmjehom (zahtjev), dok dječak uz direktan pogled ima donekle zabrinut izraz lica, traži podršku čitaoca. Njegovo penjanje na drvo, u punoj školskoj opremi s torbom na leđima i zabrinutim izrazom lica možemo tumačiti kao strah od škole. Radije bi se sklonio na drvo nego išao u školu, dok ona poziva i slavi polazak u prvi razred. Da je njegov izraz lica drugačiji, npr. da se osmjehuje i da u krošnji nema citata Dušana Radovića, njegov postupak bismo mogli tumačiti kao razigranost i avanturizam, kojem npr. djevojčica možda nije sklona pa ostaje uz stablo. Oboje su prikazani na dugačkoj udaljenosti iz prednjeg horizontalnog kuta i vertikalnog na razini oka čime su smješteni u svijet čitaoca ovog bukvara. Kod analize modalnosti, ovdje ćemo samo ukazati na odsustvo prikaza pozadine i konteksta, umjesto kojih imamo bjelinu, a paralela s proljećem i bukvarom iz 1996. je napravljena nekoliko pasusa iznad.

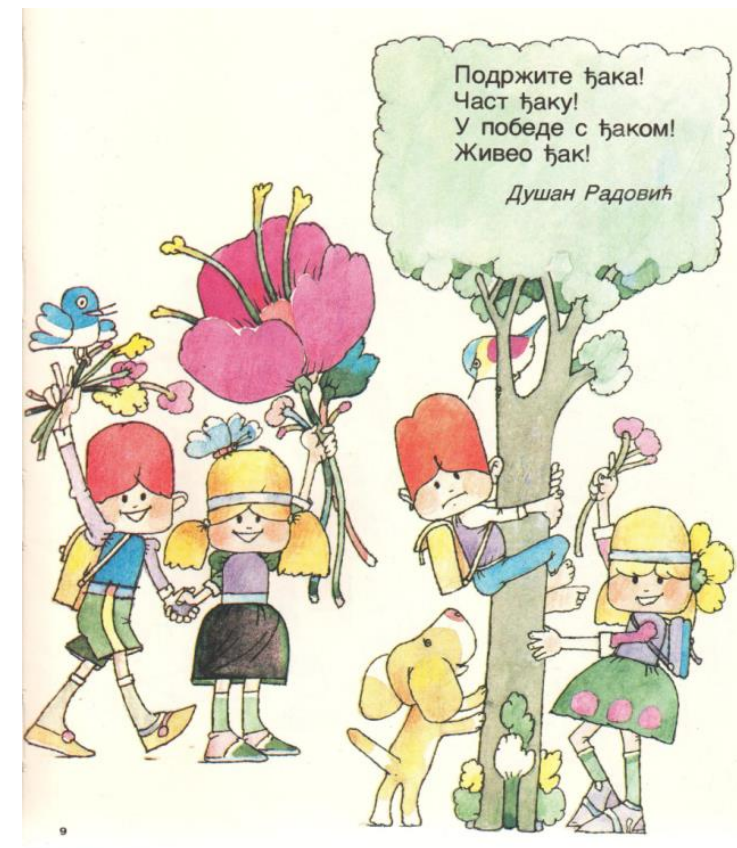

Slika 55. (Preuzeto iz Milatović, Ivković 1996.) 
Sliku 56 analizirat ćemo kao dvije odvojene slike, prvu onu koja je gore, a potom onu dolje. Na gornjoj slici vidimo dječaka i dvije djevojčice kako se voze u vlaku, što je narativna reprezentacija, akcijski proces. Akter je ovdje dječak, vektore čine njegove ruke, a cilj mu je palica kojom upravlja. Dvije djevojčice koje sjede iza njega su pratnja. Interakciju sa čitaocem ostvaruje djevojčica u sredini, koja je cijelim tijelom okrenuta prema čitaocu, upućuje mu direktan pogled i osmjehuje se (zahtjev). Na taj način uspostavlja komunikaciju sa čitaocem i šalje mu poruku: „Ovako se mi igramo da vozimo vlak.“ Kod dječaka je prisutna ponuda, jer gleda ispred sebe, a isto je sa drugom djevojčicom iz pratnje. Sve troje su nasmiješeni, uživaju u igri i zadovoljni su. Prikazani su sa srednje udaljenosti, što ih približava čitaocu svrstavajući ih u njegov intimniji prostor. Odabir kuta uobičajen je i već očekivan, pa tako ni ovdje ne izostaje prednji horizontalni kut i vertikalni na razini oka, što aktere svrstava u svijet čitaoca i izjednačava ih s njim. Modalnost je niska, pa izostaju dodatni detalji, pozadina, dubina, kontekst i ostalo. Dječak na glavi ima kapu, koja predstavlja dio uniforme strojovođe. Na donjoj slici vidimo istog dječaka i djevojčice, samo u drugoj vrsti igre. Ova slika također pripada narativnim reprezentacijama, akcijskom procesu, ali je ,podjela uloga“ drugačija jer je i igra druge vrste. Dječak je akter u neprijelaznoj narativnoj reprezentaciji, budući da nema cilj, a djevojčice su akteri u posebnom akcijskom procesu. Njihove ruke su vektori, a cilj je igračka medvjeda. Djevojčica s lijeve strane u ruci, kao produžetak vektora, a ujedno i kao sredstvo, ima žličicu kojom se igra da hrani medvjeda. Druga djevojčica ga prima oko pasa rukama namještajući ga sebi u krilo. On je predimenzioniran, njihove je veličine i one se igraju s njim kao da je beba ili dijete koje treba hraniti žličicom. Ne uspostavljaju interakciju sa čitaocem pogledom, kod obje je prisutna ponuda uz osmjehe, ali kod dječaka vidimo zahtjev u kombinaciji sa osmjehom i podignutom rukom. Dječak jednom rukom popravlja kapu na glavi, a u drugoj ima palicu, vjerojatno radnika željeznice i igra se da zaustavlja ili propušta vlak. Tim izrazom lica i gestom se obraća čitaocu: „Ovako se ja igram da radim na željeznici“. Svi akteri su prikazani na dugačkoj udaljenosti, što nam daje potpun uvid u radnju, a horizontalni prednji kut i vertikalni na razini oka ih približavaju čitaocu i izjednačavaju s njim. Modalnost je također niska, odsustvo pozadine i konteksta nam ne otkriva gdje se djeca igraju, možda su u dvorištu, u kući, u parku i sl. Djevojčica s lijeve strane ima radnu pregaču, što je uvodi u svijet odraslih jer ona odjećom podsjeća na ženu koja je majka, skuhala je ručak i sada hrani „bebu“. U analizi sljedeće slike vidjet ćemo dječaka i djevojčicu kroz četiri prizora koji razvijaju jednu radnju i postavljaju na prvi pogled neočekivanu podjelu rodnih uloga. 


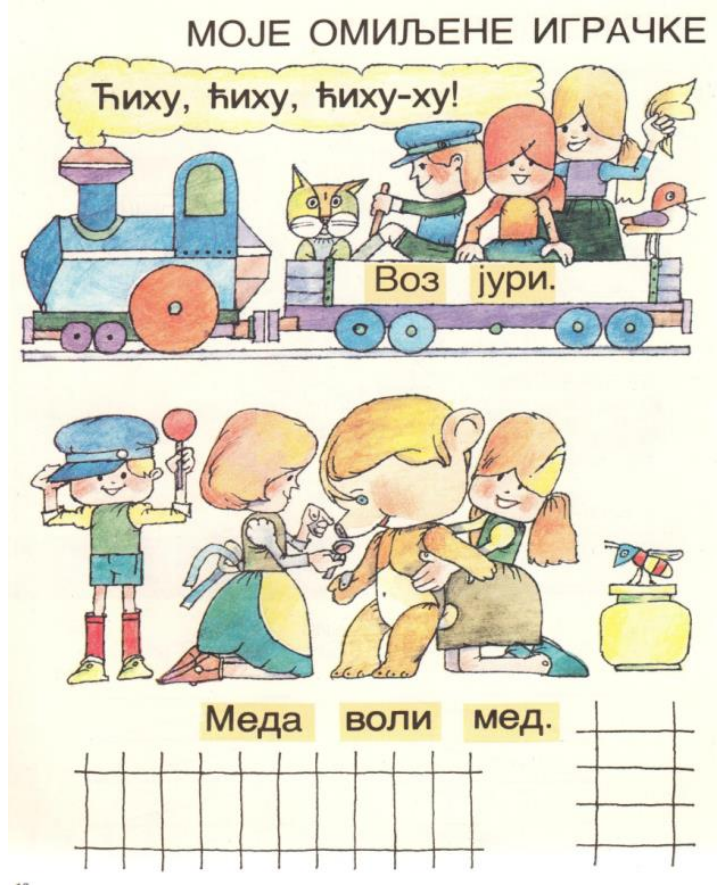

Slika 56. (Preuzeto iz Milatović, Ivković 1996.)

Slika 57 kroz četiri odvojena prizora kazuje priču o tome kako su dječak i djevojčica spasili i izliječili ozlijeđenu pticu. Ovdje nećemo analizirati svaki prizor pojedinačno, nego ćemo ih sagledati u cjelini i zatim usporediti kroz podjelu uloga i sudjelovanje u akcijskim procesima. Dječak je glavni akter na prve tri slike, dok je djevojčica u ulozi pratnje. Na prvoj slici oni ugledaju ozlijeđenu pticu, i dok djevojčica stoji sa strane, nemoćno prekriženih ruku, on stupa u akciju, spušta se do ptice i rukama (vektori) seže prema njoj (cilj). Drugi prizor nam pokazuje da dječak nosi pticu u kuću, dok djevojčica korača iza njega. U trećem prizoru on je opet akter, ruka je vektor, sredstvo je crv kojeg daje ptici u kljun, a sama ptica je cilj. Vidimo da ptica ima zavoje na sebi, iz čega zaključujemo da je možda slomila krilo i na toj slici je zbrinuta i nahranjena. Djevojčica kleči pored i gleda, ona je i tu pratnja. S obzirom na to da smo u prethodnim situacijama i u starijim bukvarima viđali situacije u kojima je djevojčica preuzimala ulogu majke i njegovateljice, bilo bi očekivano da to čini i ovdje. Ipak, čini se da je ovdje dominantnija uloga spasioca, koju preuzima dječak. Ona postaje akter tek na kraju, u posljednjem prizoru, kada je ptica već zdrava i djevojčica je pušta da odleti. Dječak je tu također akter, jer rukom (vektor), maše ptici (cilj). U svim prizorima izostaje zahtjev, dakle ni dječak ni djevojčica ne upućuju direktan pogled čitaocu, već vidimo ponudu uz dva različita izraza lica, brigu i radost. Oboje su prikazani ili sa dugačke udaljenosti ili srednje, dosljedno iz prednjeg horizontalnog kuta i vertikalnog na razini oka. Ovakvim izborom kutova pokazuje se da su situacije u kojima su se našli djevojčica i dječak sasvim moguće i za čitaoca bukvara i da 
će se i sam možda jednom naći u prilici da pomogne ozlijeđenoj ptici ili nekoj drugoj životinji. Modalnost je niska, ali opet izražajnija nego u npr. slici 58, jer ova lekcija ipak pripada zadacima u kojima se od učenika traži da opiše prikazane radnje, pa su detalji važni. Zbog toga ovdje ne izostaje pozadina i kontekst, pa tako iz drugog prizora, u kojem se vide ulazna vrata, saznajemo da pticu nose u kuću. Trećem prizoru nije potrebna pozadina jer je povezan s drugim, pa unatoč bjelini zaključujemo da se djeca o ptici brinu u kući.

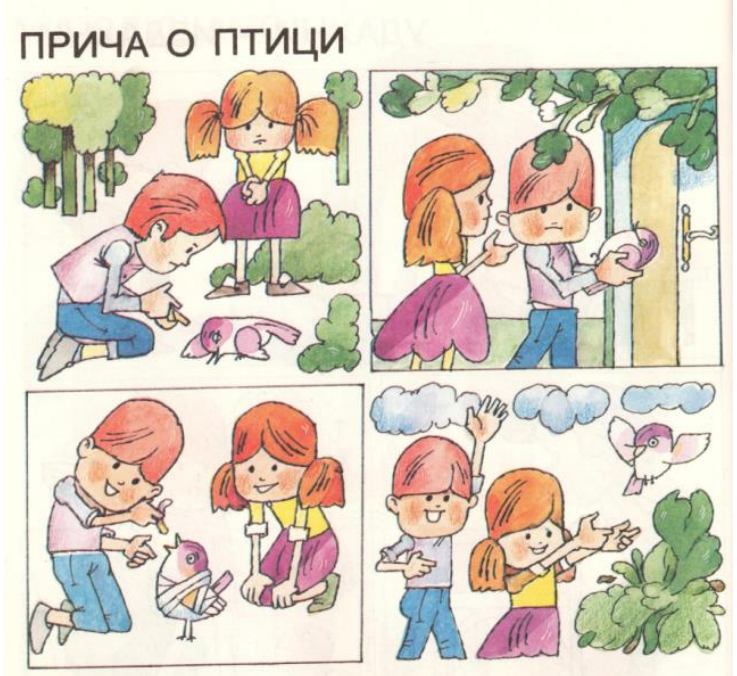

Slika 57. (Preuzeto iz Milatović, Ivković 1996.)

Slika 58. pripada konceptualnim reprezentacijama, analitičkom procesu. Cjelinu ovdje predstavlja slika koja zauzima gornji dio, na kojoj se djeca kupaju u rijeci, dok su dijelovi prikazani ispod i to jsu voda, riba i čamac. Sva tri elementa prisutna su u okviru cjeline. Sama cjelina sastoji se od više akcijskih procesa u kojima su akteri djevojčice i dječaci družeći se jedni s drugima, ili provodeći vrijeme samostalno. Vidimo da i jedni i drugi plivaju, ali je dječak dominatniji akter, generalno gledano. Npr. dok se voze u čamcu, on vesla (upravlja čamcem, određuje pravac, ima kontrolu nad radnjom), on peca, kroz vodu ide prema lopti, pravi kulu od pijeska, dok djevojčica gleda itd. Ovdje nećemo svaki akcijski proces posebno analizirati, nego ćemo ih sagledati iz perspektive ostvarivanja interakcije sa čitaocem. Budući da je ovo analitički proces, nije rijetka pojava teksta unutar slike, pa ga ovdje imao u cjelini, nalazi se u prvom je planu i odnosi se na aktere koji su tu prikazani. Njihov slikovni prikaz dopunjava rečenice. Interakciju sa čitaocem ostvaruje dječak Neša, koji stoji u vodi koja mu doseže malo iznad koljena, obje ruke ima podignute iznad glave kojima maše, gleda direktno čitaoca i upućuje mu osmjeh (zahtjev). On šalje jasnu poruku: „Pogledaj me! Volim se kupati u rijeci!“ Miša i Ana, plivaju s desne strane i dječak čitaocu šalje zahtjev uz osmijeh, jasno je da uživa u plivanju, dok je kod djevojčice prisutna ponuda i drugačiji izraz lica. Ona ne djeluje bezbrižno, 
jer su joj usta otvorena u izrazu iznenađenja. U drugom planu s lijeve strane druga djevojčica sjedi ispod suncobrana. Ona je jedina obučena i ima cipele na nogama, dok su ostala djeca na slici u kupaćim kostimima, direktno gleda čitaoca i osmjehuje mu se (zahtjev). Čitaocu poručuje da uživa u hladovini ispod suncobrana odmarajući se. Djeluje kao da preuzima ulogu starije osobe zadužene za brigu mlađih, pa stoga sjedi na povišenom terenu kako bi imala pregled nad razigranom grupom djece. Analiza modalnosti pokazuje da je ovo dosta detaljan crtež sa bogatim okruženjem, prikazom pozadine, dubine i ostalog, a razlog opet leži u vrsti bukvarske lekcije. Ovo je također slika koja od učenika traži da je opiše, da dopuni rečenice itd.

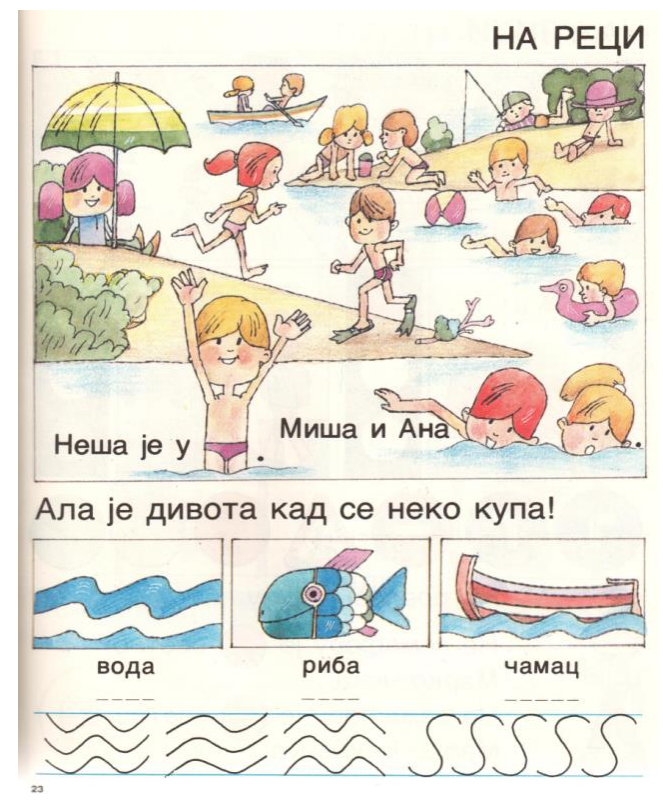

Slika 58. (Preuzeto iz Milatović, Ivković 1996.)

\subsubsection{Analiza jezičnog sadržaja u bukvaru iz 1996. godine}

Djevojčice u interakcijama sa dječacima, kada su društveni akteri nose sljedeća osobna imena (poluformalna nominacija): Ana, Cica, Ema, Emina, Gina, Irena, Marina, Merima, Mira, Nena i Tamara. Dječaci su također poluformalno nominirani imenima: Aca, Emir, Gliša, Goran, Miša, Momir, Neša, Pera, Rista, Saša, Sreten. Dječaci su dobno klasificirani imenicom mališan, a susrećemo i primjere poluformalne nominacije u kombinaciji sa tjelesnom identifikacijom npr. mali Petar, mali Gliša, mala Goga. Kada je na snazi funkcionalizacija društvenih aktera, djevojčica je princeza, a dječak lopov, princ i čobanin, dok su zajedno u funkciji putnika.

Kada djevojčice sudjeluju u društvenoj aktivnosti koja je materijalna prijelazna instrumentalna ona ima voće i bicikl, nosi marame i mete seno. Dječak s druge strane ima knjigu i naliv-pero, 
piše pismo, popeo se na drvo,on dohvati jabuku, dječaci su jurili i pali, i dječaci u funkciji čobana trče. U materijalnoj neprijelaznoj aktivnosti sudjeluje samo dječak: igra, glumi, pao.

Semiotička društvena aktivnost znatno je manje prisutna kod oba spola, u odnosu na materijalnu aktivnost. Semiotičku neprijelaznu kod djevojčica susrećemo samo u glagolu raniti, a semiotička prijelazna aktivnost $\mathrm{u}$ kojoj sudjeluju dječaci je vidjeti i to kada su dječaci u funkciji čobana, npr. videli jabuku. Oba spola učestvuju u identičnoj semiotičkoj prijelaznoj aktivnosti, ali samo kada su u ulozi princa i princeze npr. zaljubi se princeza u princa, dok je za dječaka predodređen glagol voljeti. On voli djevojčicu.

\subsubsection{Analiza slikovnog sadržaja u bukvaru iz 2011. godine}

Dječaci i djevojčice pojavljuju se zajedno na 16 stranica u slikovnim prikazima, pri čemu moramo uzeti u obzir da tom broj pripadaju i ,priče u slikama“, koje se sastoje i od po četiri zasebne slike u kojima su dječaci i djevojčice u interakciji ili sudjeluju u istom akcijskom procesu.

Najbrojnije zajedničke aktivnosti upravo su akcijski procesi. Djevojčica kao akter za vektor ima ruku ili cijelo tijelo npr. ako je cijelim tijelom nagnuta prema cilju. Ruka je u kombinaciji sa medom i pipetom, koji su istovremeno i sredstva u akcijskom procesu. Ciljevi kojima je usmjerena su: dječak, igračka medvjed, ozlijeđena ptica, velika gruda snijega kojom pravi snjegovića, jabuka. Dječak je cilj u dva slučaja, jednom kada ulazi u učionicu iza njega, a drugi put kada ga lovi jer joj je oteo balone.

Dječak u ulozi aktera za vektor ima ruku u kombinaciji s jabukom (koju pruža djevojčici), olovkom, mišem od kompjutora, daljinskim upravljačem i uhom, kada se naginje da bi bolje čuo. Ciljevi kojima je usmjerena aktivnost dječaka su: učiteljica, bandera, ozlijeđena ptica, djevojčica, kompjutor, televizor, papir na kojem piše, velika gruda snijega kojom pravi snjegovića, drugi dječak i djevojčica. Pratnju mu čini djevojčica ili grupa djece u školskim klupama koju čine i djevojčice i dječaci. Sredstva koja koristi su jabuka, volan automobila, olovka, kompjutorski miš, daljinski upravljač.

U ovom bukvaru, postoji učestaliji niz akcijskih procesa u kojima su djevojčice i dječaci ravnopravni akteri koji su svojom aktivnošću usmjereni prema istom cilju, u odnosu na bukvar iz 1996. godine. Ti ciljevi su lopta, pilići koje hrane (vektori su ruke, a sredstvo mrvice hrane), stablo koje sade (njezin vektor je ruka i kantica s vodom, koja je ujedno i sredstvo, a njegov 
vektor je ruka i štihača), snjegović kojeg zajednički prave, a cilj su jedno drugome kada su u ulogama interaktera.

S obzirom na to da su isti autori načinili bukvar iz 1996. i 2011., ali sa osvježenim i promijenjenim ilustracijama, tekstovi su ostali isti, pa je i ovdje prisutan jedan narativni proces u kojem se dječak i djevojčica predstavljaju jedno drugome. Također izostaju dijaloški oblačići, a tekst je pozicioniran ispod slike. Za razliku od bukvara iz 1996. godine, ovdje susrećemo situacije narativne neprijelazne reprezentacije u kojima postoje akteri, ali je cilj nevidljiv, pa tako djevojčica vozi romobil, ljulja se na ljuljačci, dječak trči s torbom na leđima, oboje plivaju i sjede uz predimenzioniranu knjigu iz koje čitaju.

Kada sudjeluju u reakcijskim procesima, reakteri su oboje. Pojave na koje on reagira su ptica, igračka vlak, drugi dječak i djevojčica. Djevojčica kao reakter svoju pažnju usmjerava na dječaka koji čita knjigu, i na akcijski proces u kojem dječak radi za kompjutorom.

Konceptualne reprezentacije i to u formi analitičkih procesa susrećemo tri puta. Svi procesi se raščlanjuju na cjelinu i dijelove prema mjestu koje zauzimaju na stranici. Cjelina je ili gore ili desno, dok su dijelovi dolje ili lijevo. Cjelinu čini školski prizor učiteljice i učenika u klupama, dok dijelovi predstavljaju predmete koji se nalaze u učionici (str. 8.), zatim se u ovom bukvaru ponavlja crtež kupanja u rijeci, koji smo vidjeli u bukvaru iz 1996. (slika 58), ali je akcijski proces koji predstavlja cjelinu drugačiji, dok su dijelovi ostali nepromijenjeni. Pozicioniranju cjeline i dijelova na lijevu i desnu stranu pripada slika dječaka i djevojčice u akcijskom procesu (slika 66, bit će posebno analizirana), dok dijelove čine svi elementi prisutni u dijelu slike koja predstavlja cjelinu.

Dječaci i djevojčice prikazani zajedno daju se na dugačkoj ili srednjoj udaljenosti, budući da su najčešće akteri ili reakteri, pa takav odabir daje dobar uvid u cjelinu narativne reprezentacije.

Interakciju sa čitaocem ostvaruju podjednako, pa su tako i zahtjevi učestaliji od ponude. Ponuda je udružena s osmjehom u situacijama prikaza slobodnog vremena, gdje se on igra s vlakom, ona hrani igračku medvjeda, on je zadovoljnog izraza lica u školskoj knjižnici ili uspaničenog kada se žuri u školu. Zahtjev uz osmjeh oboje upućuju kada plivaju, kada sjede ispred velike knjige, prave snjegovića, ona dok vozi romobil, on kada se predstavlja. Sve situacije su dosljedno prikazane iz prednjeg horizontalnog kuta i vertikalnog na razini oka. One su bliske čitaocu i potencijalno su ostvarive i u njegovom svijetu jer je čitalac jednak dječacima i djevojčicama prikazanima u bukvaru. Usporedit ćemo ovdje dvije na prvi pogled vrlo slične 
situacije koje se razlikuju upravo prema uspostavljanje interakcije sa čitaocem. Slika 59 nalazi se na koricama bukvara, predstavlja trenutak dokolice, djevojčica i dječak opušteno sjede ili leže i gledaju u knjigu. Njihov pogled je usmjeren na knjigu, stoga ovdje izostaje zahtjev i ostvarivanje interakcije sa čitaocem. Oni šalju poruku da rado čitaju ili listaju knjige u igri, a iz izraza lica saznajemo da ih to čini zadovoljnima. Slika 60 ima ulogu naslovnice dijela bukvara od kojeg počinje ozbiljno savladavanje slova. Dječak i djevojčica ovdje više nisu u trenucima dokolice, oni sjede uspravno, knjiga nije polegnuta nego je postavljena za čitanje i oboje šalju zahtjev čitaocu. Njegov izraz lica je blago nasmiješen, dok je ona ozbiljna, ali istovremeno zadovoljna. Uspostavljanjem direktnog pogleda, oboje pozivaju čitaoca da im se pridruži i da skupa s njima nauči slova.

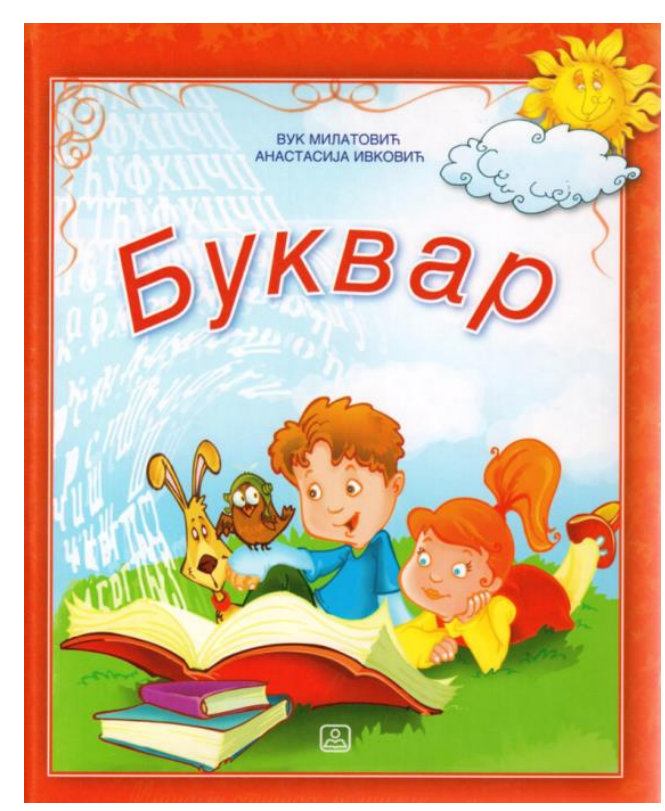

Slika 59. (Preuzeto iz Milatović, Ivković 2011.)

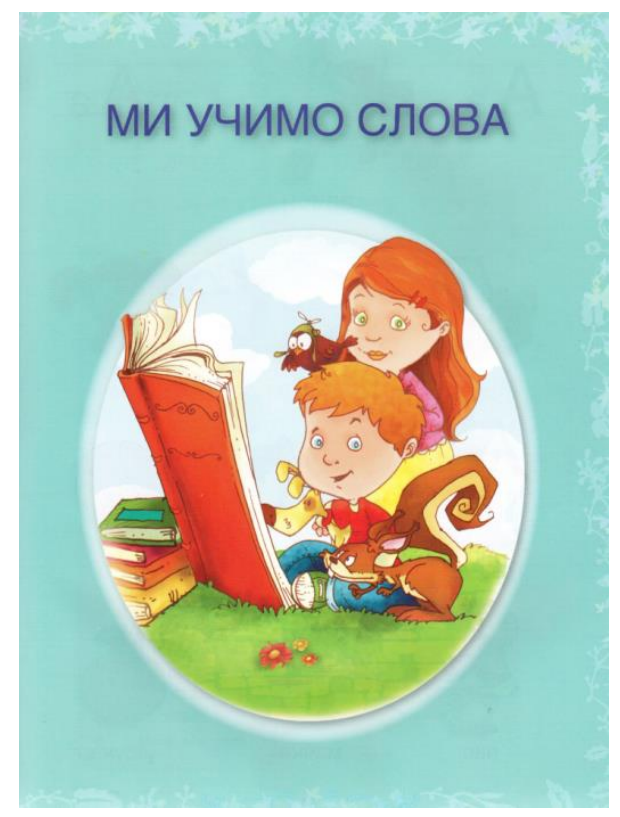

Slika 60. (Preuzeto iz Milatović, Ivković 2011.)

Modalnost je općenito manje niska u bukvaru iz 2011. u odnosu na bukvar iz 1996. godine. Prikazi djevojčica i dječaka su realističniji, više je individualnosti u odnosu na npr. bukvar iz 1974. u kojem su sva djeca gotovo identična. Općenito slike imaju više detalja, posebno kada se prikazuju prostori učionice i knjižnice, u odnosu na prostore u kojima se djeca igraju. Djevojčice dijele školske klupe sa dječacima, a zimi, u prizoru pravljenja snjegovića, nose i hlače. U ostalim prigodama su u haljinama, ali kroj više ne podražava odjeću odraslih. Elemente narodne nošnje ovdje nailazimo samo u jednom primjeru, koji se odnosi na dječaka iz ruralnih krajeva. Na str. 58. dječak piše pismo djevojčici koja mu se sviđa (slika ilustrira tekst), i ima prepoznatljive dijelove narodne nošnje, kapu šajkaču i prsluk. 
Slika 61 pripada istoj lekciji kao i slika 56, na njima se prikazuju omiljene igračke djevojčica i dječaka i oni u igri. Starije izdanje bukvara je u vlakiću je prikazalo dječaka i dvije djevojčice, dok su ovdje igra i igračke rodno odvojeni. Gornja slika pripada narativnim reprezentacijama, reakcijskom procesu. Reakter je dječak, koji ima pogled usmjeren na vlakić koji se kreće, a ovdje je u funkciji pojave ili fenomena. S obzirom na to da je pogled usmjeren na igračku, izostaje zahtjev, pa tako nema uspostavljanja interakcije sa čitaocem direktnim pogledom (ponuda). Dječak je prikazan na dugačkoj udaljenosti, koja pruža mogućnost sagledavanja veličine kružno spojene pruge, u središtu koje dječak leži. Izbor prednjeg horizontalnog kuta i vertikalnog na razini oka ovog dječaka svrstava u svijet čitaoca bukvara i predstavlja ga kao nekoga ko je mu je vrlo sličan. Prikaz djevojčice sa omiljenim igračkama pripada akcijskim procesima. Ona je akter, njezina ruka je vektor, sredstvo je med, a cilj je velika igračka medvjeda s kojom se igra. Izbor udaljenosti, horizontalnog i vertikalnog kuta identičan je kao na slici iznad, jer se i ovdje šalje ista poruka. Ni ona ne ostvaruje direktnu interakciju sa čitaocem, budući da gleda u igračku (zahtjev). Modalnost je na obje slike niska, izostaju detalji, dubina, umjesto konteksta i okruženja prisutna je žuta boja. S obzirom na to da ovdje ne susrećemo uobičajenu bjelinu, izbor žute možemo tumačiti smještanjem akcijskog i reakcijskog procesa u zatvoreni prostor, u kuću. Igračke koje posjeduje djevojčica su medvjedići različitih veličina i boja i dva crteža tih istih igračaka. U bukvaru iz 1996. dvije djevojčice se igraju da hrane medvjedića $i$ to čine kao da hrane bebu. Ovdje je djevojčica sama, ali ima četiri medvjedića i svi kao da čekaju da budu nahranjeni. Ona preuzima ulogu hraniteljice, dok je dječaku dana mogućnost da se igra sa dinamičnom igračkom koju pokreće moderna mehanika upotrebom daljinskog upravljača. 


\section{MОJЕ ОМИЉЕНЕ ИГРАЧКЕ}

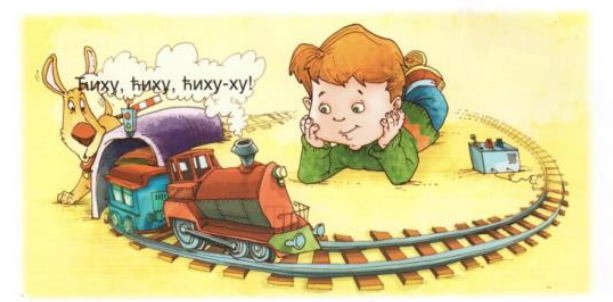

Воз јури.

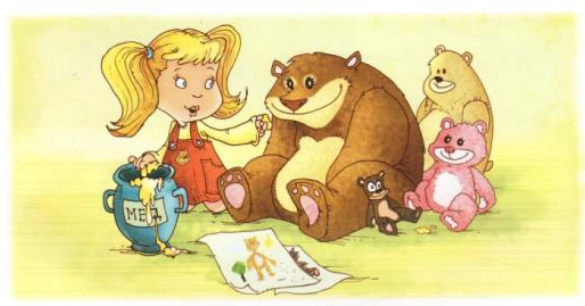

Меда воли мед.

Slika 61. (Preuzeto iz Milatović, Ivković 2011.)

Slika 62 prikazuje lekciju Priča o ptici s kojom smo se susreli u bukvaru iz 1996. (Slika 57), gdje su djevojčica i dječak bili u neravnopravnim ulogama. Ona je uglavnom bila pratnja, a on glavni akter u akcijskom procesu pružanja pomoći ozlijeđenoj ptici. U bukvaru iz 2011. u istoj lekciji, djevojčica više nije pratnja. Ovdje nećemo analizirati svaku od četiri slike posebno sa svakog aspekta, nego ćemo u analizi proći kroz elemente akcijskog procesa i objediniti postupke koji se ponavljaju. Sva četiri crteža pripadaju narativnim reprezentacijama, akcijskim procesima i u svakoj su akteri i djevojčica i dječak sa zajedničkim ciljem. Na prvom crtežu oboje rukama (vektori) sežu prema ozlijeđenoj ptici (cilj), ona malo i tijelo naginje. Na drugom crtežu dječak pruža pomoć ptici, obje ruke su vektori, ptica je cilj, ali djevojčica ovdje ne stoji mirno prekriženih ruku, nego je u položaju koji prethodi čučnju i pruža ruke prema ptici (vektori) što je čini akterom. Na trećoj slici oboje ravnopravno hrane pticu (cilj), ona joj daje tekućinu pipetom (sredstvo), dok on pruža zrno hrane (sredstvo). Zadnja slika ih prikazuje kako mašu ptici koja je poletjela i tu su njihove ruke vektori, a ptica je cilj. Svi crteži imaju ponudu, jer akteri gledaju pticu i ne ostvaruju interakciju sa čitaocem. Prikazani su ili sa dugačke ili srednje udaljenosti, iz prednjeg horizontalnog kuta i vertikalnog na razini oka, što ovu situaciju čini realnom i ostvarivom u čitaočevom svijetu. Modalnost je niska, ali ipak izražajnija u odnosu na npr. sliku 61. jer ovdje je ipak prikazano okruženje, detalji, pozadina, dubina itd. Razlog opet leži u vrsti lekcije, jer je se od učenika očekuje da što bolje opiše događaje prikazane na slikama. 


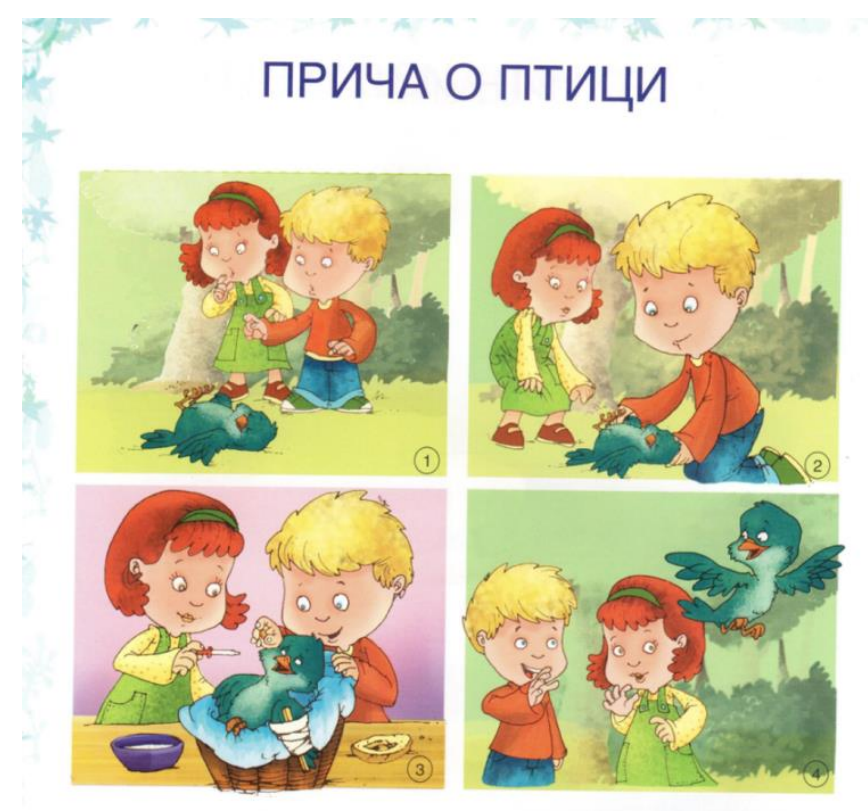

Slika 62. (Preuzeto iz Milatović, Ivković 2011.)

Slika 63. sastoji se od šest prizora u kojima su djevojčice i dječaci prikazani ili kao akteri ili kao reakteri. U svim prikazima su podjednako zastupljeni, mada nisu sasvim ravnopravni. Sagledat ćemo ih ovdje u jednoj paralelnoj analizi, kao i u prethodnom primjeru. Prvi prizor sastoji se od jednoj reakcijskog i jednog akcijskog procesa. Djevojčica i dječak koji čita knjigu crvenih korica čine reakcijski proces. Ona je reakter, dok je on pojava ili fenomen. Dječak pored njega pripada akcijskom procesu u kojem sam sudjeluje. One je akter, ruka je vektor, kao produžetak je tu olovka, koja mu je istovremeno i sredstvo za pisanje. Bilježnica je cilj. Kad pogledamo sliku kao cjelinu, nevezano uz navedene procese, vidimo da oba dječaka sjede, udubljena u čitanje i pisanje, dok djevojčica djeluje kao netko tko ne pripada toj grupi, jer stoji pored i gleda. U drugom prizoru su dječak i djevojčica ravnopravni, oboje su akteri, njihove ruke su vektori, a zajednički cilj im je lopta, koju dobacuju jedno drugome. Treći prizor prikazuje iste aktivnosti u kojima oboje sudjeluju; riječ je akcijskom procesu u kojem su i djevojčica i dječak akteri, ruke su im vektori, sredstva također zajednička - mrvice kruha, a cilj su pilići koje hrane. Četvrti prizor podsjeća na sličnu sliku iz bukvara iz 1965. na kojoj dječak i djevojčica u uniformama gorana sade drvo (slika 64). Usporedimo li je sa spomenutim prizorom na slici 63, vidimo da se razlikuje u samo dva detalja - cilj i sredstvo kod djevojčice. Oba prizora pripadaju akcijskim procesima, akteri su i dječak i djevojčica, cilj im je zajednički, na slici 63. Je to sadnica, a na slici 64. rupa u zemlji. Dječaci su pozicionirani sa lijeve strane, čak imaju istu alatku - štihaču, koja je ovdje u funkciji produžetka vektora i ujedno je sredstvo za ostvarenje akcijskog procesa. Djevojčice su na obje slike s desne strane, s tim da djevojčica 
iz 60-ih godina mladicu stavlja u iskopanu rupu, dok je u bukvaru iz 2011. stabalce već zasađeno i ona ga zalijeva vodom, dok on poravnava zemlju. Isto su prikazani sa dugačke udaljenosti, izbor kuta je dosljedno prednji horizontalni i vertikalni na razini oka. Dakle, kako se čitalac bukvara, Titov pionir ili goranin iz 1965. godine mogao poistovjetiti sa sadnjom i pošumljavanjem i sl, to isto može i učenik prvog razreda iz 2011. godine, koji dobiva lekciju iz očuvanja prirode. Interakcije uspostavom direktnog pogleda nema, pa je u oba primjera prisutan samo zahtjev. Modalnost je na obje slike niska, s tim da noviji prizor nudi više boja i nagovještaj okruženja, pa je prikazana gola zemlja i nebo. Peti prizor na slici 63 sadrži akcijski i reakcijski proces, poput prvog prizora. Djevojčica je ovdje također reakter, a dječak koji se služi kompjuterom je pojava. On je pak akter u akcijskom procesu koji je iz njezine perspektive pojava, tj.fenomen. Njegove ruke su vektori, cilj je tipkovnica, tj. miš na kojem ima položenu drugu ruku. Posljednji prizor, u kojem djevojčica i dječak sjede zajedno u fotelji i gledaju televizijski program, pripada akcijskim procesima. On je akter, njegova ispružena ruka je vektor, daljinski upravljač je produžetak tog vektora, a istovremeno i sredstvo kojim mijenja televizijske kanale. Djevojčica koja sjedi pored njega je pratnja. Niska modalnost već je opisana u komparaciji slika 63 i 64, dakle detalji i okruženje daju se tek toliko da kontekstualiziraju radnju.

\section{Шта они раде?}
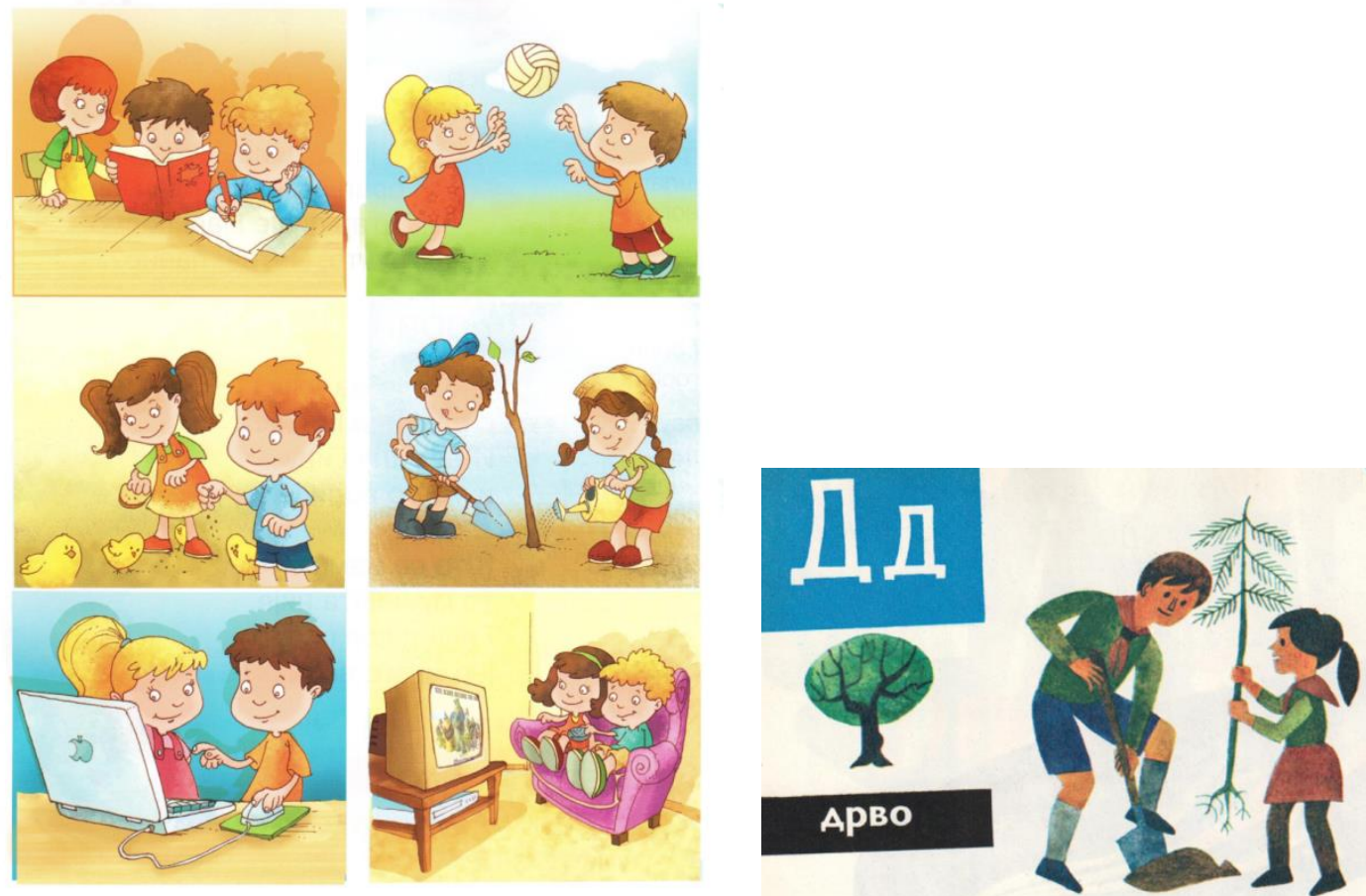

Slika 63. (Preuzeto iz Milatović, Ivković 2011.)

Slika 64. (Preuzeto iz Mitić, 1965.) 
Slike 65. i 66. analizirat ćemo paralelno, budući da je na obje prisutna situacija koje nije bilo do sada ni u jednom bukvaru iz prethodnih godina, a čini sastavni dio i školovanja i odrastanja - stvaranje i iskazivanje simpatija. Slika 65. pripada konceptualnim reprezentacijama, analitičkom procesu, koji je organiziran na način da su s lijeve strane dijelovi, a s desne je cjelina. Cjelinu čini jedan akcijski proces u kojem je akter dječak, vektor je njegova ruka, sredstvo je jabuka, a cilj je djevojčica kojoj pruža jabuku. Interakciju sa korisnikom bukvara ne ostvaruju ni jedno od njih dvoje, budući da gledaju jedno drugo, pa je prisutan zahtjev. Zanimljiva je njezina gesta, ona kažiprst prinosi ustima, glava joj je nagnuta u stranu suprotnu od njega i jedna noga joj je blago odignuta od tla. Kao da se sprema odmaknuti se, ali oklijeva, prst na ustima nam govori da razmišlja, dvoumi se. Nije sigurna želi li uzeti jabuku koju joj dječak pruža. S druge strane, njegovo držanje tijela odaje jasnu namjeru i sigurnost postupka. Okrenut je frontalno prema nama, jedna ruka mu je skrivena iza leđa, a druga je potpuno ispružena prema djevojčici. Bilo bi logično da ga vidimo s boka, iz profila, ali on zapravo čitaocu demonstrira svoju simpatiju prema djevojčici i želju da joj pokloni jabuku. Oboje su prikazani sa dugačke udaljenosti, što nam i daje uvida u cjelovitost njihovih položaja tijela, a odabir prednjeg horizontalnog kuta i vertikalnog na razini oka svrstava ih u svijet sedmogodišnjaka koji ovaj bukvar koristi. Modalnost je, u odnosu na druge slike, ovdje dosta visoka, ali stoga što je riječ o analitičkom procesu. Na slici koja čini cjelinu detaljno je prikazano okruženje, da bi se onda sve što čini cjelinu raščlanilo na dijelove: ptice, jabuke, stablo bez krošnje, lišće, stablo sa krošnjom i na dnu dječak i djevojčica. Ipak, njihov prikaz u okviru dijelova potpuno je drugačiji u odnosu na scenu udvaranja iz cjeline. Ovdje nema akcijskog procesa, radnja ne postoji, oni su oboje frontalno okrenuti čitaocu, ona je zagledana u daljinu (ропиda), dok on ostvaruje interakciju direktnim pogledom (zahtjev). Njihovi položaji tijela ovdje šalju drugačije poruke u odnosu na scenu s jabukom, pa se situacija može promatrati kao prizor koji je prethodio darivanju. Ona stoji u čvrstom stavu, razmaknutih nogu s rukama iza leđa, ali izbočenih laktova, odmaknuta je od dječaka i ne djeluje pristupačno. On pak stoji spojenih nogu, ruke su mu opuštene niz tijelo koje je blago okrenuto od djevojčice, ali mu je glava usmjerena prema njoj što ukazuje na neodlučnost. On molećivo gleda čitaoca i kao da kaže: „Ja bih joj prišao.“ Slika 66 pokazuje veće šanse za ostvarivanje simpatije, ali i ponešto obrnute uloge. Ovdje je djevojčica u lozi aktera, vektor čini njezino tijelo kojim je lagano nagnuta prema dječaku, koji je cilj. Oboje su prikazani sa dugačke udaljenosti, kao i na slici 65 , što nam omogućava da u potpunosti sagledamo njihovo držanje tijela i položaj u prostoru. Ona je blago zakošena, dio leđa okrenula je prema dječaku, ali se naginje u njegovom pravcu. Ruke su joj iza leđa i gleda ga ispod oka što su sramežljive geste. Dječak je frontalno okrenut 
prema čitaocu, a glava mu je okrenuta prema djevojčici. Ruke drži u džepovima što je gesta ravnodušnosti, mada joj upućuje blagi osmijeh. S obzirom na to da oboje gledaju jedno drugo, izostaje zahtjev, pa nema ostvarivanja interakcije sa čitaocem direktnim pogledom. Oni ipak pripadaju njegovom svijetu jer su prikazani iz horizontalnog prednjeg kuta i vertikalnog na razini oka. Analiza modalnosti daje dodatne informacije o emocijama i iskazivanju naklonosti. Ovdje ih nedvojbeno ispoljava djevojčica što dodatno podcrtava srce na njezinoj haljini. Prisutnost emocija naglašena je okruženjem, tj. pozadinom koju čini žuta podloga ispunjena srcima iz kojih izranjaju sjene djevojčice iz dječaka.
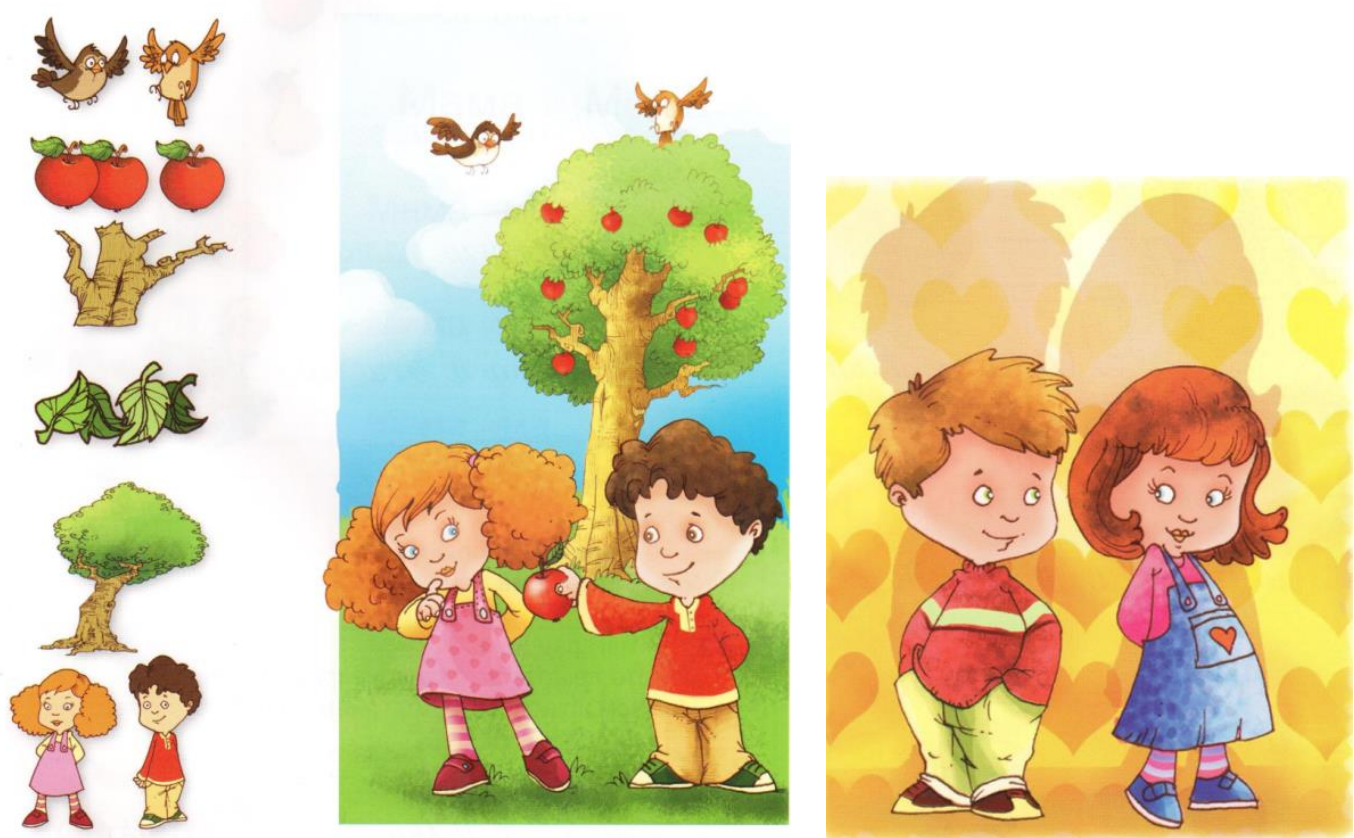

Slika 65. (Preuzeto iz Milatović, Ivković 2011.)

Slika 66. (Preuzeto iz Milatović, Ivković 2011.)

\subsubsection{Analiza jezičnog sadržaja u bukvaru iz 2011. godine}

S obzirom na to da je jezični sadržaj u domeni rodnih odnosa djevojčica i dječaka identičan onome iz bukvara iz 1996., vidi pod 2.3.6. 


\subsubsection{Zaključne napomene}

Kvantitativna slikovna zastupljenost dječaka u bukvaru iz 1965. godine, koji su prikazani sami ili u međusobnoj interakciji dominira ne samo nad zastupljenošću djevojčica, nego i nad situacijama u kojima su djevojčice i dječaci prikazani zajedno. Bez obzira na to što je interakcija u najvećoj mjeri određena školskim obavezama ili igrom u kojoj djeca preuzimaju uloge odraslih, jasno je da dječaci imaju dominantnije uloge: on otvara prozor - ona briše ploču; on inicira pravljenje snjegovića - ostali prihvaćaju; on predvodi skupinu djece koja se igra rata ili maršira poput vojske - ona je bolničarka; on je trgovac - ona kupuje itd. Kad pogledamo izbor vektora kod oba spola, vidimo da su kod djevojčica ograničeni na cvijeće i ukrasne grančice, dok su kod dječaka dominiraju razna oružja, alati i predmeti koji imaju praktičnu namjenu. Ciljevi prema kojima je usmjerena aktivnost za djevojčice svedeni su na igračke, predmete za dekoraciju i brisanje, dok dječak svoje djelovanje upravlja prema raznim vrstama životinja koje lovi, čuva, hrani i igračkama koje podrazumijevaju dinamičnu igru poput lopte, rakete, zmaja i sl. Interakcija s korisnikom bukvara uspostavljena je direktnim pogledom koji sadrži zahtjev, dosljednom upotrebom prednjeg horizontalnog kuta i vertikalnog na razini oka, što objedinjeno šalje poruku: ,mi se ovako igramo i ovo radimo isto kao i ti / ti se možeš igrati i raditi sve ovo što mi radimo“. Interakciju podjednako ostvaruju oba spola svim prethodno navedenim sredstvima. Unatoč zakonski ostvarenim pravima žena, koje su u trenutku izlaska ovog bukvara bila na snazi 19 godina, i većoj radnoj emancipaciji žena u socijalističkom društvu, uloge djevojčica i dječaka zadržavaju vrlo tradicionalnu podjelu na muške i ženske. Djevojčica svojom pojavom, odjećom, ulogom u igri i zadacima preuzima ulogu majke, njegovateljice i osobe zadužene za ukrašavanje. Dječaci dominiraju bukvarom kao vojskovođe, ribolovci, avanturisti - u krajnjem kao pokretači radnje. Analiza jezičnog dijela sadržaja podudara se sa slikovnim. Devojčice kao društveni akteri imenovane poluformalno (Lela, Đurđina), ali i formalno, imenom i prezimenom npr. Hristina Đorđević, Ognjenka Đaković, za razliku od dječaka koji su prisutni samo pod imenom i nadimicima npr. Časlav, Čeda, Filip, Isa, Lune, Vesa itd. Djevojčice su relacijski identificirane prema drugoj djevočici, koja im je prijateljica kao Đurđinine drugarice. Kada su u funkciji učenica, djevojčice se dodatno određuju kao odlične učenice, a kada ih se dobno klasificira kao djevojčice, opisuje ih pridjev dobra. Na taj način se ističe njihov uspjeh u školi, poslušnost i pristojno vladanje. S druge strane, dječaci su postupkom funkcionalizacije određeni kao sportaši, naravno uz to što su također učenici i đaci. Za razliku od djevojčica, dječaci sudjeluju u čitavom nizu društvenih aktivnosti od kojih su najbrojnije materijalne, bilo prijelazne instrumentalne, neprijelazne, interaktivne aktivnosti 
koje se značenjski odnose na radnje koje nešto stvaraju i pokreću u kontekstu igre ili obavljanja zadataka npr. načiniti lađice, bacati kamen, napraviti golubarnik, puštati zmaja, sašiti loptu, loptati, rvati, trčati, smučati itd. Kada je riječ o semiotičkim aktivnostima, sami dječaci sudjeluju u komunikaciji (reći, pitati, razgovarati) i nešto apstraktnijim oblicima semiotičkih neprijelaznih aktivnosti htjeti i snivati. Zajedničke aktivnosti djevojčica i dječaka i u jezičnom smislu određuju njihove društvene uloge pionira, gorana i učenika, ali se ukazuje i na društveni sustav kojem pripada 1965. godina upotrebom riječi drugarica. Kao i u slikovnim sadržajima, dječaci i djevojčice zajedno sade, igraju se, рjevaju, sviraju (materijalne aktivnosti), dok se semiotičke aktivnosti odnose na glagole komuniciranja: reći, upitati, odgovoriti. Ovdje ćemo podvući i jedan primjer pojave emocija u tekstu na str. 95. kada se u kazalištu djevojčice uplaše vuka na sceni, a dječak je taj koji ih tješi i hrabri. Dakle, one su plašljive, on je hrabar.

Bukvarom iz 1975. godine dominiraju odrasle osobe izvan obitelji, pa je u odnosu na ostale bukvare iz korpusa ovdje malo djevojčica i dječaka općenito. Djevojčice susrećemo kao aktera (i to samo kada je u ulozi Crvenkapice) i interaktera, gdje su dvije djevojčice jedna drugoj cilj. Crvenkapica za ciljeve ima vuka i cvijeće i jedino ona ostvaruje interakciju sa čitaocem bukvara direktnim pogledom. Odstupanje od pravila prikaza aktera i interaktera iz već uobičajenog horizontalnog prednjeg kuta i vertikalnog na razini oka nalazimo u primjeru kada Crvenkapica uz pomoć ptica leti, budući da je dana iz djelomično visokog vertikalnog kuta čime je čitaocu dana mogućnost da vidi ono što i ona, ali da ipak ne uspostavi moć nad njom. Djevojčice se po izgledu ne razlikuju od onih u bukvaru iz 1965, budući da i ovdje imaju dugačku kosu i nose suknje i haljine. Imena koja nose su Ana i Gordana i sudjeluju u aktivnostima koje su pretežno mateterijalne prijelazne i odnose se na domenu pripreme hrane, praviti tortu, premijesiti i u jednom slučaju tražiti savjet. Kod semiotičkih aktivnosti, imamo samo jednu, negirani oblik glagola svidjeti koji je zapravo njezina reakcija na recepte za tortu koje joj daju razne životinje. Dječak poput djevojčice sudjeluje u akcijskom procesu, ali za razliku od nje javlja se i u govornom procesu. Vektori su mu ruke koje produžuje štap za pecanje i novine, a cilj su ribe koje lovi. On se dakle ponavlja u svojoj ulozi lovca. Prisutni su i zahtjev i ponuda, a dječak bez iznimke pripada svijetu korisnika bukvara i jednak mu je s obzirom na izbor prednjeg horizontalnog kuta i vertikalnog na razini oka. Dječak nosi imena Đura i Raša, što su zapravo nadimci (neformalna nominacija) i kada sudjeluje u društvenoj aktivnosti, to su materijalne aktivnosti u kojima nešto ili čini ili posjeduje npr. šarati šare, imati olovke, crtati kuću itd. Dječaci i djevojčice prikazani zajedno u slikovnim dijelovima imaju manje 
zajedničkih aktivnosti u ovom bukvaru, nego 1965. Budući da ovdje izostaje zajednička sadnja drveta, ukrašavanje škole, redarske aktivnosti i sl. kada su prikazani zajedno, među njima nema interakcije, osim u jednom primjeru igre kada dječak broji brojalicu. Akteri su i jedni drugi, ali je samo djevojčica u ulozi pratnje. Vektori su uvijek ruke, ali ovdje bez pomoćnih sredstava npr, poput olovke i sl. Direktni pogled nije obavezan, ali ga ostvaruju i jedni i drugi, a odabir kutova je istovjetan njihovim pojedinačnim prikazima. Jezični sadržaji su još manje zastupljeni, pa samo susrećemo primjere poluformalne i neformalne nominacije u kojima se djeca nazivaju samo imenom ili nadimkom (Ivan, Ema, Miša, Nana, Neša), a aktivnosti se svode na glagole kretanja (ići, susresti se) u materijalnim aktivnostima koje čine dječaci.

Bukvar iz 1996. donosi veću zastupljenost i djevojčica i dječaka, a posebno njihovih zajedničkih prikazivanja. Oboje su najčešće akteri, kada se prikazuju nezavisno jedni od drugih. Djevojčice su tada i akeri i cilj, ali i pratnja, dok je dječak akter, interakter, ali i cilj. Ruka kao vektor kod djevojčice je često potpomognuta cvijetom, a ciljevi su joj također cvijet, leptir, ptica. Izbor ciljeva kod dječaka je raznovrsniji i upućuje na dinamičnu igru npr. papirići na stolu, kolut za igru, papirnati zmaj, drugi dječaci, lopta, volan, ptice itd. Sredstva također doprinose dinamici igre, romobil i štap što ga određuje kao većeg avanturistu i aktivnijeg u igri u odnosu na djevojčicu. Dječaci i djevojčice prikazani zasebno daju se sa srednje ili dugačke udaljenosti, a kada su skupa, uvijek su predstavljeni sa dugačke udaljenosti kako bismo stekli uvid u njihov položaj u prostoru, aktivnost i raspored elemenata. Interakciju sa čitaocem direktnim pogledom uspostavljaju i jedni i drugi bilo da se nalaze okruženi pripadnicima svoga spola ili jedni s drugima. Izbor horizontalnog i vertikalnog kuta u svim situacijama djevojčice i dječake svrstava u svijet čitaoca bukvara i izjednačava ih s njim čime im se šalje poruka „Ja sam kao i ti/I ti se ovako igraš ili ovo radiš.“ Kada se dječaci i djevojčice prikazuju zajedno u akcijskim procesima, donekle je podjednak odnos ciljeva kojima su usmjereni: ptica, stablo, slova, ali nisu jednako aktivni u igri jer npr. on se penje uz stablo, dok ga ona samo dodiruje, kada su zajedno u vlaku, on vozi, djevojčice sjede pored njega i sl. Dječaku je djevojčica ovdje uvijek pratnja, dok je njoj pratnja dječak, ali i druga djevojčica. Kada usporedimo izbor sredstava koja koriste dječaci i djevojčice, njegova uvijek imaju i nešto iz asortimana oružja ili pribora za lov npr. štap za pecanje, dok su njezina sredstva cvijeće, harmonika, kantica, tijesto i sl, dakle predmeti iz domene kulinarstva, dekoracije ili umjetnosti. Garderoba je ovdje također tradiocionalno podijeljena na mušku i žensku u smislu da djevojčice i dalje nose haljine i suknje, kosa im je od svih bukvara ovdje posebno hiperbolizirana, a dječaci su u hlačama. Treba 
podsjetiti na paralelu između bosonogosti dječaka u bukvaru iz 1965. i 1996. U starijem bukvaru su bosonogi dječaci bili vezani uz prostor sela, dok se takav izbor tridesetak godina kasnije odnosi na bezbrižnost i opuštenost, na oblast igre koja ima naglašenu maštu (dječak jaše na pužu i sl.). Analiza jezičnog sadržaja pokazuje da se i dječaci i djevojčice imenuju poluformalno i neformalno, imenima i nadimcima Lela, Ljiljana, Goran, Marko, Mita, Miša itd. I jedni i drugi se tjelesno identificiraju pridjevom mali (mali Petar, mala Goga) ili imenicom mališani. Kada je riječ o identifikaciji prema funkciji, dječaci su prijatelji, pekari, lopovi, prinčevi i čobani, a djevojčice su princeze, dok zajedno dijele funkciju putnika. Materijalne društvene aktivnosti u najvećoj mjeri određuju oba spola, djevojčica se ljulja, pušta pticu, ima voće, vozi bicikl, nosi maramu, mete sijeno itd. Ipak, impresivan je popis stvari koje dječak posjeduje u odnosu na djevojčicu, on ima; pušku, kravatu, školsku torbu, zaprežna kola, vola, ambar sa žitom. Kada bismo iz ovog niza izuzeli školsku torbu, dječak bi bio izjednačen odraslom čovjeku. Po pitanju semiotičke aktivnosti, emocije koje iskazuje djevojčica je ljutnja, a oboje ih obuhvaća semiotička prijelazna aktivnost zaljubiti se, ali samo kada su u ulogama princa i princeze (više o ovome u poglavlju Zaključak). Ovoj skupini društvenih aktivnosti pripada i glagol voljeti, koji se odnosi samo na dječaka, koji voli djevojčicu.

U posljednjem bukvaru iz korpusa, iz 2011. godine dječaci i djevojčice su najzastupljeniji u zajedničkim kontekstima i međusobnim interakcijama u odnosu na prethodne bukvare. Dominiraju akcijski procesi u kojima su i jedni i drugi akteri i ciljevi. Dječak kao akter uz ruku za vektor ima niz sredstava, a to je konopac od papirnatog zmaja, knjiga, ruža, kamen, mreža za hvatanje leptira, četkica za zube. U popisu ciljeva prema kojima je usmjeren u aktivnostima koje sam izvodi, ili u društvu drugih dječaka, dominiraju predmeti koji su uključeni u igru: brodić kojeg spušta niz vodu, lopta, koš za igranje košarke, volan od automobila, papirni zmaj, ali i drugi dječak kojem priskače u pomoć jer je ozlijeđen, ptica, škola, žaba itd. Pratnju dječaku čini ili drugi dječak ili pas. Djevojčica je svega dva puta prikazana sama, jednom u okviru analitičkog procesa, a drugi put $\mathrm{u}$ akcijskom procesu sa neprikazanim ciljem. Kada je u društvu dječaka njezine ruke kao vektore produljuju med i pipeta, koji su istovremeno i sredstva i pripadaju u domenu hranjenja, a njegove olovka, kompjutorski miš, daljinski upravljač što su sve tehnički predmeti kojima se piše ili upravlja elektroničkim uređajima. Njezini ciljevi su dječak, medvjed igračka, povrijeđena ptica, gruda snijega od koje se pravi snjegović, jabuka, nasuprot dječakovih ciljeva koji su bandera, učiteljica, djevojčica, kompjutor, televizor, papir za pisanje i identično kao i kod nje povrijeđena ptica i gruda snijega. Oba spola se daju sa 
srednje udaljenosti ukoliko se javljaju u analitičkom procesu, dok su prikazani sa dugačke udaljenosti kada su skupa i sudjeluju u akcijskom procesu. Oni neizostavno pripadaju svijetu korisnika bukvara i on se sa lakoćom može poistovjetiti s njihovom igrom i situacijama jer se daju sa prednjeg horizontalnog kuta i vertikalnog na razini oka. Interakciju direktnim pogledom oboje ostvaruju (zahtjev), on kada leti na ptici, ide prema školi i poziva čitaoca da mu se u tome pridruži, ona kada vozi romobil, hrani igračku medvjeda, oboje kada plivaju, sjede ispred velike otvorene knjige. Novina u bukvaru iz 2011. je veća prisutnost i dječaka i djevojčica koji npr. sjede skupa u školskim klupama, upoznaju se, iskazuju simpatije i sl. Kada je riječ o izboru garderobe, djevojčice zimi nose hlače, dok su u ostalim situacijama u haljinama, ali općenito odjeća manje oponaša odjevne predmete odraslih. Dijelove narodne nošnje susrećemo samo u jednom primjeru, gdje dječak iz ruralnih krajeva piše pismo djevojčici i na glavi ima kapu šajkaču i nosi prsluk. Jezični dijelovi bukvara ne donose novine u odnosu na izdanje iz 1996. godine, pa se djeca i dalje nazivaju samo imenima ili nadimcima, karakteriziraju pridjevom mali i mališani, funkcionaliziraju kao i u prethodnom bukvaru itd. a podudarne su i društvene aktivnosti u kojima sudjeluju i jedni i drugi. Podvući ćemo samo da dječak plače u jednoj situaciji i to kada izgubi novac.

\subsection{Obiteljski odnosi}

\subsubsection{Analiza slikovnog sadržaja u bukvaru iz 1965. godine}

U bukvaru iz 1965. godine na 12 slika prikazane su situacije iz obiteljskog života koje uključuju više od jednog člana uže ili proširene obitelji, a na četiri slike prikazani su sami članovi obitelji, dva puta dječak i isto toliko baka. Svi prikazi pripadaju narativnim reprezentacijama, akcijskim procesima. Kada je majka u ulozi aktera, za vektore ima ruke u kombinaciji sa kuhačom. Ciljevi su posuda s jelom, žena koja prodaje na tržnici, dijete koje čini prve korake, rublje na konopcu za sušenje, sinovi, šivaća mašina. Kao sredstvo koristi kuhaču i torbu. Otac je prisutan samo na jednoj slici u čitavom bukvaru (slika 67), također je akter, vektori su ruke i kruh, a cilj je stol. Dječak u obiteljskom kontekstu za vektore ima same ruke ili ruke u kombinaciji sa vrčem i naliv-perom, koji su istovremeno i u funkciji sredstva. Ciljevi su mu stol, žena koja prodaje na tržnici, rublje koje se suši, voda iz umivaonika, pismo (koje piše baki), ćuran, džepovi. Djevojčica za vektore ima ruke koje su ili same ili uz produžetak koji čini žlica i bočica sirupa, koji su ujedno i sredstva. Ciljevi prema kojima je usmjeren akcijski proces kojem ona stremi su tanjur, bolesna baka i štednjak. Baka u ulozi aktera za vektore ima ruke a produžetke vektora čine zrna kukuruza i pletaće igle, jer su ciljevi kokoši koje hrani kukuruzom i čarapa koju plete. 
Produžeci vektora su i ovdje u funkciji sredstava koji pomažu ostvarenju akcijskog procesa. Djed je prisutan samo na jednoj slici gdje je u ulozi aktera, vektore predstavljaju njegove ruke, a cilj mu je šubara. U društvu je sa unukom, koji mu je pratnja. Kada je riječ o ostvarivanju interakcije sa čitaocem direktnim pogledom (zahtjev), ostvarena je na samo jednoj slici gdje tu vrstu kontakta uspostavlja otac. Kod svih ostalih aktera prisutna je samo ponuda i to dosljedno. Sve obiteljske situacije pripadaju svijetu čitaoca bukvara jer su neizostavno prikazane iz prednjeg horizontalnog kuta, a izbor vertikalnog kuta uvijek je na razini oka što aktere čini jednakima čitaocu. Postoji samo jedna situacija relativnog odstupanja, a to je ujedno i jedini prikaz obitelji na okupu koja je dana iz djelomičnog visokog kuta, kod kojeg čitalac ima moć (slika 67) na što ćemo se posebno osvrnuti nekoliko redova niže. Modalnost je očekivano niska, budući da je to karakteristika čitavog bukvara, ali možemo uočiti obrazac prema kojem se akteri prikazuju. Majka je često zauzeta kućanskim poslovima, pa nosi radnu pregaču, baka ima naočale (slabo vidi, stara je) i živi u selu, djed je vizualno istaknut velikim brkovima, a djevojčica kao i u dosadašnjim situacijama odjećom podražava izgled majke. Prostorije koje se odnose na dom često su neidentificirane pa vidimo samo npr. stolicu i dvije igračke, ili luster i vrata i sl. Prostor se identificira sa više ili manje detalja samo kada je se u njemu odvija važna radnja, npr. priprema i serviranje obiteljskog objeda (slika 67) ili djevojčica baki daje lijek u spavaćoj sobi (slika 70).

Slika 67 predstavlja jedinu situaciju obitelji na okupu, koju ovdje čine: otac, majka i dvoje djece - dječak i djevojčica. Svo četvero su akteri i sudjeluju u zasebnim akcijskim procesima, ali troje ih ima isti cilj. Majka za vektor ima ruku i kuhaču, koja je ovdje i sredstvo, a cilj je posuda sa jelom na pećnici. Druga ruka također čini vektor, jer njome prima posudu za ručku. Otac kruh stavlja na stol, pri čemu su ruke i kruh vektori, dok je stol cilj. Djevojčica za vektore ima ruke i tanjur, a stol je ponovo cilj. Dječak također ima isti cilj, a njegove ruke i vrč su vektori. Od sva četiri aktera interakciju sa korisnikom bukvara ostvaruje samo otac, on ga gleda direktno (zahtjev), dok je kod ostalih prisutna ponuda. Svi akteri su prikazani sa dugačke udaljenosti i iz prednjeg horizontalnog kuta. Oni pripadaju svijetu korisnika bukvara i on se može poistovjetiti sa prikazanom scenom iz obiteljskog života. Vertikalni kut ovdje nije sasvim na razini oka, nego je djelomično visok čime je čitalac postavljen na poziciju moći. Takav izbor vertikalnog kuta, u kombinaciji sa dugačkom udaljenošću mu daje dobar uvid u cjelokupnu situaciju, raspored elemenata i detalje koji su ovdje dosta zastupljeni. Modalnost je niska, budući da crtež ne izgleda realistično, ali s druge strane obiluje detaljima pa vidimo i zavjesu i na prozoru, sliku na zidu, policu s knjigama, ukras na polici, vrata itd. Kontekst radnje je priprema ručka gdje 
majka kuha, a ostali serviraju stol za zajednički objed. Sve se dešava u prostoriji koja je ujedno i kuhinja i trpezarija, ali služi kao radna soba. U donjem desnom kutu vidimo postavljen radni stol i stolicu, a na stolu su dvije bilježnice i dvije olovke. Jedna bilježnica je otvorena i upravo izbor djelomično visokog vertikalnog kuta omogućava čitaocu uvid u napisanu zadaću. Položaj radnog stola u prostoriji za pripremu i konzumaciju hrane ilustrira stambene prilike šezdesetih godina u SFRJ. Ova slika je ujedno i primjer tadašnjeg skučenog načina stanovanja u gradovima, gdje je bilo sasvim uobičajeno da se školski zadaci obave u kuhinji, često zapravo i za trpezarijskim stolom. Ako ćemo se osloniti na prikaz detalja na slici (otac ima kravatu oko vrata) i radno vrijeme u socijalizmu, možemo zaključiti da će obitelj na ovoj slici ručati. Djevojčica, poput majke, oko pasa ima svezanu radnu kecelju, dok su otac i dječak u manje radnoj garderobi.

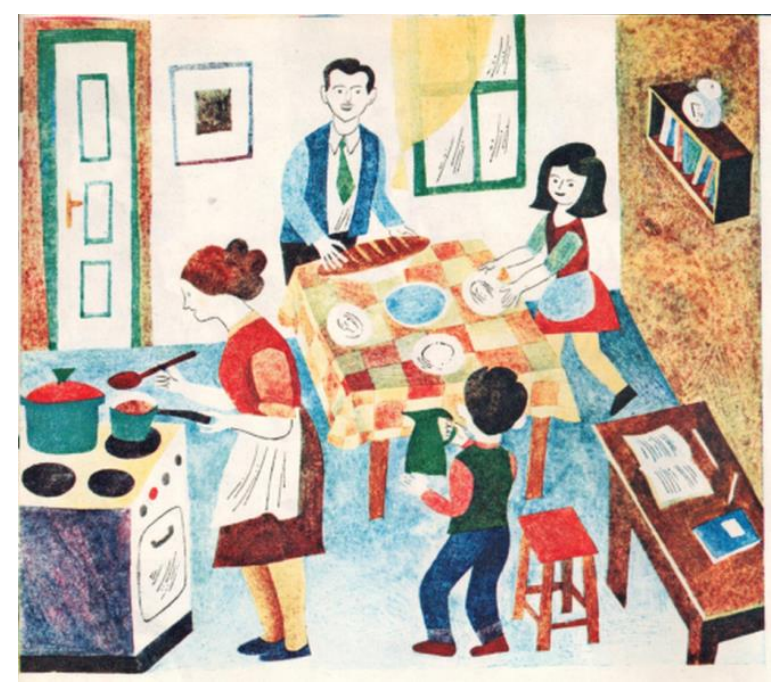

Slika 67. (Preuzeto iz Mitić 1965.)

Slika 68 također pripada akcijskom procesu sa više nego uobičajeno prikazanih detalja. Ovdje je dio obitelji u zajedničkom akcijskom procesu, majka i dva sina. Svo troje su akteri, vektori su njihove ruke i torbe, a cilj je žena koja prodaje voće na štandu. Majka i dječaci ne ostvaruju interakciju sa čitaocem (ponuda), nego žena koja prodaje i ona šalje poruku: „I ti ovako dolaziš na tržnicu i kupuješ voće.“ Akteri i njihov cilj su prikazani sa srednje udaljenosti, što ih čini bliskima promatraču, iz prednjeg horizontalnog kuta i vertikalnog na razini oka. Analizom modalnosti otkriva se dosta detalja, pa vidimo da je zima jer su krovovi štandova prekriveni snijegom, podloga je bijela, akteri nose rukavice i šalove, žene imaju marame na glavi, a dječaci kape. Kontekst tržnice je dodatno razrađen dodavanjem dubine, pa vidimo i štandove koji su u drugom planu, prodavača na jednome od njih, kutije i burad pored štandova. Budući da jedan 
od dječaka nosi košaru/torbu za namirnice, podrazumijeva se da ih je majka povela da joj pomognu nositi ono što će kupiti. Oni su ovdje u ulozi pomagača.

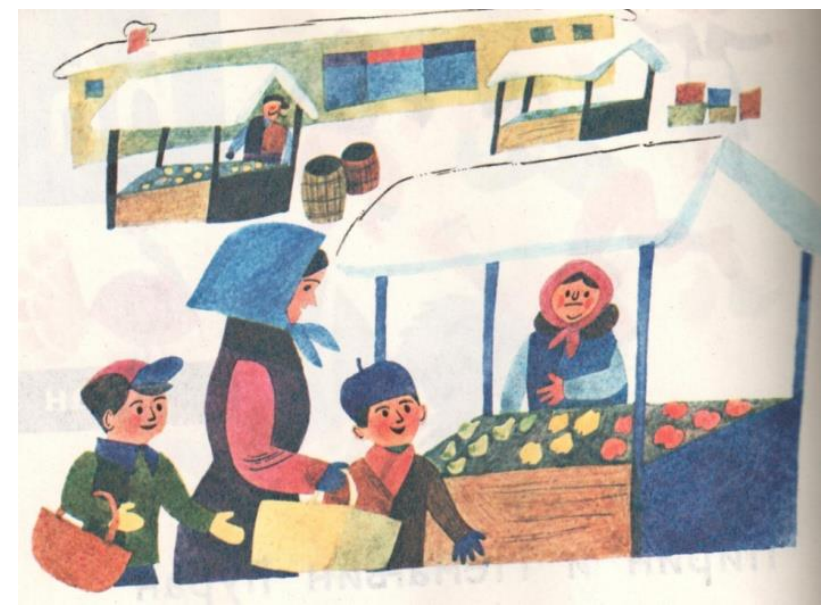

Slika 68. (Preuzeto iz Mitić 1965.)

Slika 69 na prvi pogled može izgledati kao scena u kojoj majka ljulja bebu u kolijevci, ali kako slika ilustrira tekst, naslov daje detalje: „Ljiljana ljulja brata“. Ovo je je narativna reprezentacija u kojoj je akcijski proces upravo opisan naslovom, dakle djevojčica je akter, njezina ruka je vektor, a cilj je beba u kolijevci. Ona ne uspostavlja direktnu komunikaciju pogledom sa čitaocem (ponuda), jer je zagledana u daljinu. Prikazana je sa široke udaljenosti, iz prednjeg horizontalnog kuta i vertikalnog na razini oka. Dakle, pripada svijetu korisnika bukvara i ova scena je nešto što pripada svakodnevici i sasvim je uobičajeno. Modalnost je niska, crtež prikazuje samo osnovne elemente bez dubine, detalja, bogatijeg spektra boja i sl. Djevojčica je odjevena poput odrasle osobe, ima strukirani prsluk preko košulje, suknju i doima se vrlo odraslom. Poput prikaza djevojčica koje su same ili se igraju, ona je i ovdje preuzima ulogu majke ili njegovateljice, što ćemo vidjeti na slici 70 .

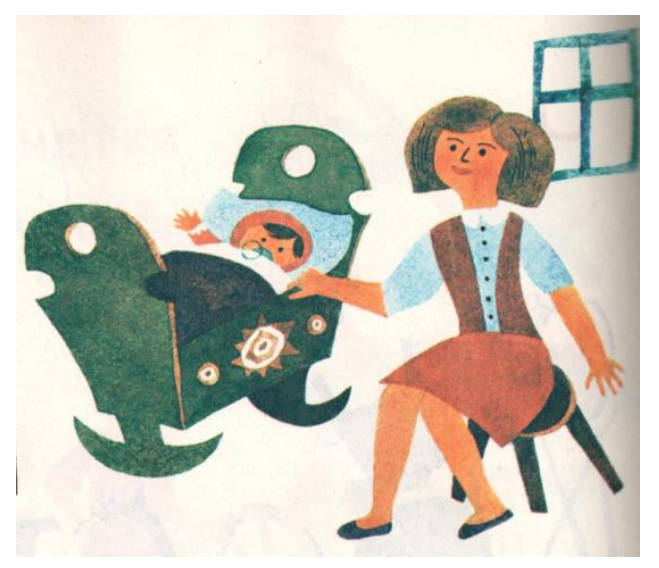

Slika 69 (Preuzeto iz Mitić 1965.) 
Slika 70. akcijski proces smješta u spavaću sobu u kojoj je djevojčica akter, njezine ruke su vektori koji za produžetak imaju žlicu i bočicu sirupa, koji su istovremeno i sredstvo. Baka je cilj. Možemo reći da je prizor dan na djelomičnoj srednjoj udaljenosti, budući da je djevojčica prikazana malo više ispod linije pasa, ali opet ne sasvim cijela da bi to bila dugačka udaljenost. Prednji horizontalni kut i vertikalni na razini oka situaciju njegovanja bolesne bake svrstavaju u svakodnevicu čitaoca bukvara. Ipak, ni baka ni djevojčica ne uspostavljaju direktan kontakt pogledom, pri čemu izostaje zahtjev, pa je kod obje prisutna samo ponuda. Modalnost je niska, a prostorija je označena kao spavaća soba prikazom kreveta sa uzglavljem i noćnim ormarićem. Na noćnom ormariću se nalazi čaj i bočica sa tabletama, što daje informaciju o tome da je baka već neko vrijeme bolesna, liječi se, ali djevojčica u trenutku prikazanim na slici donosi pravi lijek. Djevojčica demonstrira brigu prema starijima za koju se podrazumijeva da preuzimaju mlađi članovi obitelji.

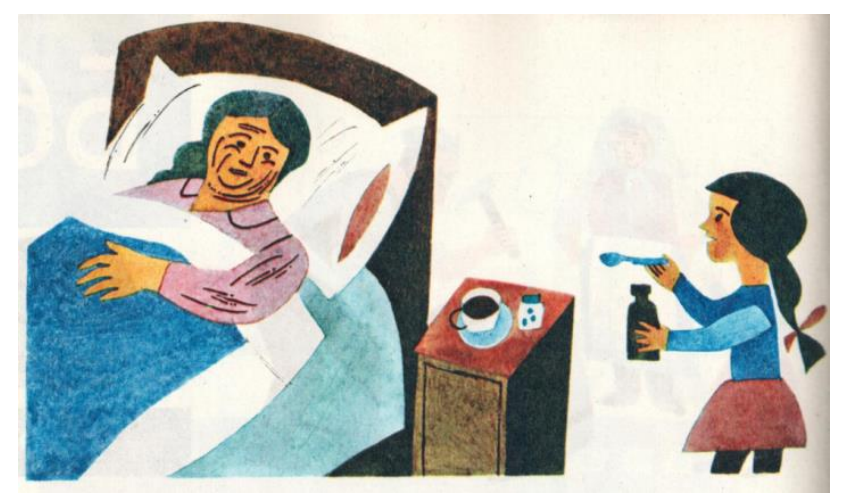

Slika 70. (Preuzeto iz Mitić, 1965.)

\subsubsection{Analiza jezičnog sadržaja u bukvaru iz 1965. godine}

Dječaci i djevojčice u kontekstu u kojem su prikazani kao članovi obitelji, nose imena koja smo već susretali, jer su to isti „likovi“ koje pratimo kroz bukvar.

Društveni akteri su češće određeni relacijskom identifikacijom: tata, mama, majka, sin. Češce se javljaju kombinacije u kojima je prisutna npr. relacijska identifikacija i ime, ili dobna klasifikacija i ime i sl: najmlađi sin, stariji sin, seja Jasna, baba Borka, unuka Branka, bakica (tako unuk oslovljava baku), unuk, mamino pile (posevizacija, tako majka naziva sina), deda stari, starija sestra, mlađi dečak, nastariji dečak. Tjelesno se identificira samo baka i to sijedom kosom. Prisutna je jedna identifikacija imenicom junak, kojom se određuje brat, ali je zanimljivo to što je dječak u tom trenutku još beba (str. 84, pjesma Jovana Jovanovića Zmaja). 
Najbrojnije društvene aktivnost u kojima sudjeluju članovi obitelji su materijalne prijelazne instrumentalne i materijalne prijelazne interaktivne aktivnosti.

Dječak sudjeluje u sljedećim materijalnim prijelaznim aktivnostima: posmatrati (krajolik), nacrtati (zeca), umiti (uši), naučiti (pjesmu), zviždati (ćuranu), gledati (u zemlju), čuditi (sadržaju svojih džepova), stidjeti (vikanja na sestru), pisati/zapisati (slova), jesti (kolača), izbrisati (grešku u pisanju), pronaći (gumicu), sakupljati (klasje), nositi (vodu žeteocima). Npr. Nidža je gledao u zemlju; Ćira i Nemanja mu zvižduću; Mama, naučio sam pesmu o ćuranu; Kad bude žetva, sakupljaću klasje i nosiću vodu žeteocima. Djevojčici pak pripadaju potpuno drugačije aktivnosti iz domena njege bolesnih i kuhanja: otići (u apoteku), kupiti (lijek), kuhati ( jelo), skuhati (koku), ispeći (paprike), nasjeći (kupus) brisat (tanjure i viljuške). Za majku se vezuju aktivnosti iz iste domene: prostirati (rublje), vratiti (se kući), izviniti se (sinu), posmatrati (sliku na zidu). Npr. Majka je sada pažljivo posmatrala sliku na zidu. Baka sudjeluje u sljedećim aktivnostima: piti (lijek), zvati (svoje koke), nositi (kukuruz). Npr. Baka je pila lek i ubrzo ustala. Evo vam baka nosi kuruza.

Materijalne prijelazne interaktivne aktivnosti ćemo najbolje prikazati ako nabrojimo glagole koje susrećemo prema obiteljskim ulogama koje društveni akteri imaju. Majka: pomagati, reći (sinovima), obratiti (sinovima). Djevojčica u ulozi unuke: pozvati (lekara) moliti (baku), smijati se, a dječak u ulozi unuka je prisutan kroz glagole: javljati (radosnu vijest), doći (kod bake), čitati (baki pjesme i priče), pomagati (baki u poslu), grliti (baku), ljubiti (baku), pitati (npr. unuk piše baki pismo: Pomagat ću ti, čitat ću ti i sl.) Dječak grli i ljubi baku. Dječak u ulozi sina sudjeluje u slijedećim aktivnostima: poslušati (majku), čestitati (majci Dan žena), poljubiti (majku), pokloniti (majci poklon), odgovoriti (majci), igrati se, pomagati (majci). Majka upita sina, miluje kćerku. Npr. Danas sam čestitao mami praznik Dan žena. Poljubio sam je i poklonio joj buket ljubičica; Mama miluje Kaju.

Materijalna neprijelazna aktivnost je znatno manje zastupljena pa se na dječaka odnose glagoli putovati i raditi, baka se razboljeti i ustati $i$, mama šivati, a djevojčica poslovati, u značenju obavljanja kućanskih poslova.

Kada je riječ o semiotičkim prijelaznim aktivnostima nisu posebno brojne, ali u njima dominira majka u glagolima: primijetiti (crtež zeca na zidu), naljutiti (na nekoga), povjerovati (u krivnju sina), obradovati (poklonu). Npr. Kad se majka vratila sa posla kući, primjetila je da je neko u sobi na zidu nacrtao zeca. Prvo je posumnjala u najmlađeg sina, ali nikako nije mogla da 
poveruje da je to on nacrtao; Mama se mnogo obradovala. Prisutan je jedan primjer u kojem se djed verbalno obraća unuku: kaže unuku, a za na dječaka se odnosi glagol čitati.

Semiotičku neprijelazna susrećemo u glagolima: saznati, htjeti (izbrisati grešku), koji se odnose na dječaka i obradovati u primjeru u kojem se majka obraduje sinovom poklonu. Npr. Hteo Nidža da izbriše grešku u domaćem zadatku.

Na kraju ovog dijela u preglednoj tablici ćemo sažeti kombinacije odnosa koji se pojavljuju u ovom bukvaru, dati njihov pregled i navesti aktivnosti u kojima članovi obitelji sudjeluju. Tablica objedinjuje rezultate analize slikovnog i jezičnog sadržaja.

Tablica 1. Obiteljski odnosi u bukvaru iz 1965. godine

\begin{tabular}{|c|c|c|}
\hline Broj & DRUŠTVENI AKTERI & DRUŠTVENA AKTIVNOST \\
\hline 1. & MAJKA I SIN/SINOVI & $\begin{array}{l}\text { - } \text { kupuju na tržnici } \\
\text { - } \text { majka uči bebu hodati } \\
\text { - } \quad \text { sin pomaže majci raširiti rublje na sušenje } \\
\text { - } \text { majka odgaja - traži da djeca priznaju nepodopštinu (str } \\
\text { 122) } \\
\text { - opominje sinove da uče i prestanu se igrati (str. 93) } \\
\text { - } \text { rješava situaciju nesporazuma između brata i sestre (str. } \\
\text { 195) }\end{array}$ \\
\hline 2. & OTAC I SIN & 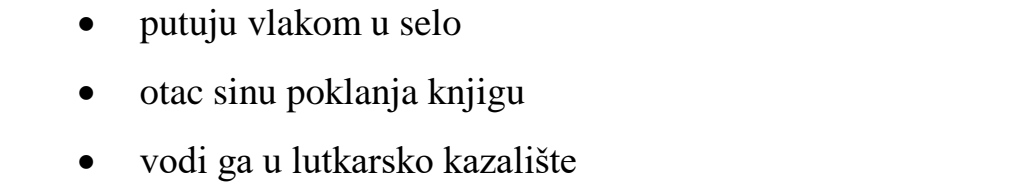 \\
\hline 3. & MAJKA I KĆERKA & $\begin{array}{l}\text { - dok majka šije na mašinu, kćerka kuha ručak } \\
\text { - majka kuha }\end{array}$ \\
\hline 4. & OTAC I KĆERKA & - nema odnosa \\
\hline 5. & BAKA I UNUKA & $\begin{array}{l}\text { - } \quad \text { zove liječnika zbog bolesne bake } \\
\text { - } \quad \text { kupuju lijek za bolesnu baku } \\
\text { - daje joj lijek }\end{array}$ \\
\hline 6. & BAKA I UNUK & $\begin{array}{l}\text { - } \quad \text { piše baki pismo } \\
\text { - } \quad \text { čitat će joj priče i pjesme jer je naučio slova }\end{array}$ \\
\hline
\end{tabular}




\begin{tabular}{|l|l|ll|}
\hline 7. & DJED I UNUK & $\begin{array}{l}\bullet \\
\text { djed daje savjet unuku (“Čizma glavu čuva, šubara je } \\
\text { kvari”, str. 82) }\end{array}$ \\
\hline 8. & DJED I UNUKA & $\bullet$ nema odnosa \\
\hline 9. & BRAT I SESTRA & $\begin{array}{l}\text { u kupaoni sestra bratu daje upute kako da se temeljito } \\
\text { umije }\end{array}$ \\
& & $\begin{array}{l}\text { mlađi brat krivi stariju sestru da mu je uzela gumicu, ona } \\
\text { mu nudi svoju gumicu }\end{array}$ \\
\hline 10. & $\begin{array}{l}\text { OBITELJ } \\
\text { (majka, otac, sin, kćerka) }\end{array}$ & \begin{tabular}{l} 
priprema objeda, majka kuha, ostali serviraju stol \\
\hline
\end{tabular}
\end{tabular}

\subsubsection{Analiza slikovnog sadržaja u bukvaru iz 1974. godine}

Kao što je već spomenuto ranije, u ovom bukvaru najzastupljeniji su društveni akteri koji pripadaju grupi odraslih osoba izvan obitelji, s toga je prikaz članova obitelji sveden na četiri slikovna prikaza. Prisutne su i narativne i konceptualne reprezentacije. Kod narativnih je to akcijski proces u kojem sudjeluju majka i kćerka, obje kao akteri ili kćerka u ulozi aktera kojoj je majka cilj. Djed i unuk su također akteri u akcijskom procesu, njihovi vektori su ruke i lopate, a cilj je drvo koje zajednički sade. Članovi obitelji su prisutni i u okviru konceptualnih reprezentacija u kojima se npr. daju sličice majke i kćeri uz predmete koje one koriste ili izrađuju ili opet konceptualna reprezentacija prikaza obiteljskih portreta gdje su dva sina i dvije kćeri sa lijeve i desne strane majčinog portreta, koji se nalazi u sredini. Može se zaključiti da je majka centralna figura obitelji, s obzirom na pozicioniranje. Obitelj se slikom prikazuje iz bliske ili dugačke udaljenosti i prednjeg horizontalnog kuta. Kada je riječ o vertikalnom kutu, osim prikaza na razini oka, kod kojeg nema odnosa moći, u jednom primjeru prisutan je djelomično niski kut koji moć daje akterima (slika 71, bit će posebno analizirana). Modalnost je niska ukoliko je riječ o crtežima, koji u ovom bukvaru svakako dominiraju. Izuzetak čini jedna fotografija koja ne pripada Titu, a to je slika majke i kćeri (slika 71).

Slika 71. nalazi se na samom početku bukvara, ali kako ovaj bukvar nema numerirane stranice, nije moguće navesti broj stranice. Zauzima središnje mjesto na stranici, iznad slike je natpis mama, mama! velikim štampanim slovima, a ispod pisanima. Pripada akcijskom procesu, u kojem je djevojčica akter, njezine ruke su vektori, a majka je cilj. Obje su prikazane iz bliske udaljenosti i prednjeg horizontalnog kuta. Vertikalni kut je ovdje djelomično niski, koji njih dvije stavlja u položaj nadređenosti čitaocu bukvara. Čitalac je u poziciji divljenja njihovoj 
ljubavi koja se ostvaruje zagrljajem, toj ljubavi se daje na važnosti i veličini. Direktne interakcije sa čitaocem ovdje nema, jer majka i kćerka gledaju jedna drugu, pa je ovo primjer ponude. Već pri prvom koraku u analizi modalnosti vidimo da je ovo originalna fotografija koja je u bukvaru iz 1974. a i ranije, u 1965. bila rezervirana samo za Tita. Fotografija je u boji, dobro osvijetljena, oštrih detalja, što doprinosi visokoj modalnosti. S obzirom na to da su obje prikazane na bliskoj udaljenosti, izostaje okruženje i kontekst, ali ono ovdje i nije važno budući da je akcent na bliskosti koje majka i kćerka ostvaruju. Njihova tjelesna povezanost dodatno je naglašena vrlo sličnim nijansama boje kose.

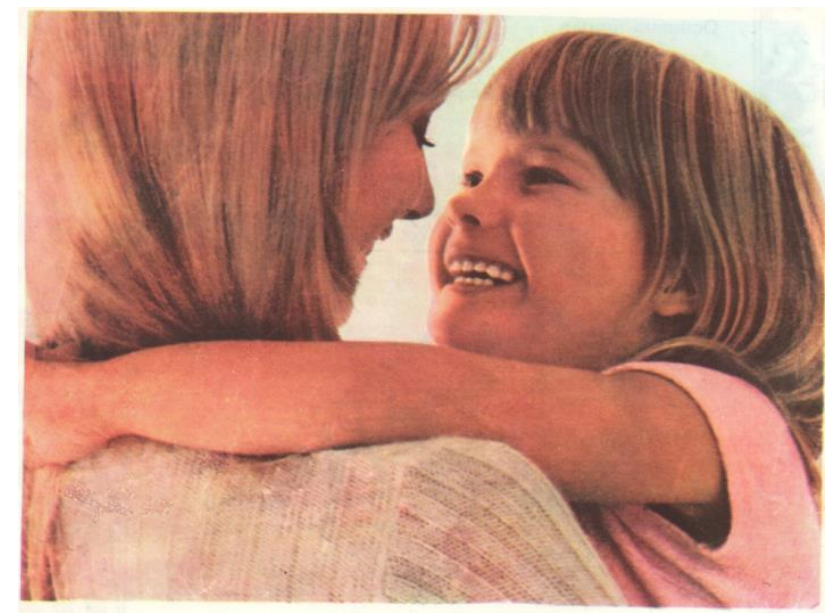

Slika 71. (preuzeto iz Janjušević, Milardić, Timotijević 1974.)

Slika 72. pripada konceptualnim reprezentacijama, klasifikacijskom procesu u kojem je prikazana prikrivena sistematika. Slika predstavlja „fotografiju“ proširenog izdanja obitelji sa izleta na Frušku goru. Ispod slike daje se popis svih članova obitelji, iz kojeg se vidi da su tu i ujaci, stričevi, pa i fijakerista koji se „fotografirao“ sa obitelji. Klasifikacijski proces obuhvaća raspored članova obitelji, u drugom redu se nalaze stariji članovi obitelji koji su hijerarhijski nadređeni mlađima koji su u prvom redu (ispod njih). Interakciju sa čitaocem bukvara ostvaruju svi članovi obitelji, osim žene u drugom redu, druge s lijeve strane i dječaka u prvom redu, drugoga s lijeva (mornarska uniforma), koji žmire. Svi su prikazani sa srednje udaljenosti, iz prednjeg horizontalnog kuta i vertikalnoga na razini oka. Ovakvim odabirom, ostvarena je bliskost sa promatračem. Modalnost nam otkriva da obiteljski portret ne predstavlja suvremenike čitaoca bukvara, nego osobe iz dalje prošlosti. To zaključujemo iz odjevnih predmeta: djed nosi oficirsku uniformu koja ne pripada JNA, žene nose haljine i šešire, a dječaci mornarska odijela. Prikazana obitelj mogla bi pripadati vremenu između dva svjetska rata, a u prilog tomu idu i arhaična osobna imena Sofronije, Jefimija, Teofil. 


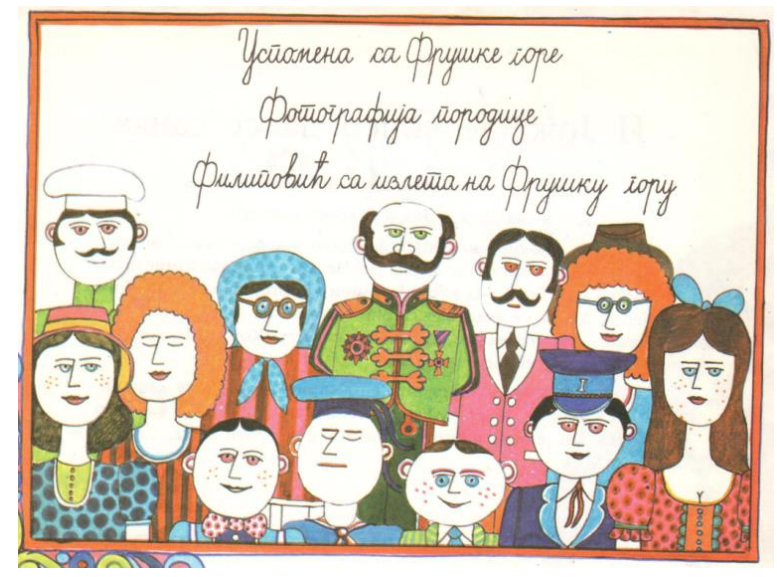

Slika 72. (Preuzeto iz Janjušević, Milardić, Timotijević 1974.)

\subsubsection{Analiza jezičnog sadržaja u bukvaru iz 1974. godine}

Društveni akteri su najčešće određeni relacijskom identifikacijom u kombinaciji sa osobnim imenom, koje se daje bez prezimena (poluformalna nominacija): sin Petko, deda Rade i deda Sofronije, baba Femka, tata Teofil, mama Jefimija, Pava, Đurđa, Ljubica, ujak Fadil, stric Filip. Djevojčice i dječaci koje susrećemo u kontekstu obiteljskih odnosa zovu se: Mima, Miša, Maša, i potom niz arhaičnih imena koja pripadaju obiteljskom portretu iz prošlosti (slika 72): Jefta, Dafina, Sofija, Filmena, Fedor, Trifun. Dječaci i djevojčice u obiteljskom kontekstu su dobno klasificirani imenicom djeca, a prisvojni pridjev moj/moja susrećemo u odnosu majke i sina. Kada sin piše majci piše pisme, kaže mojoj mami, dok se ona njemu obraća sa mili moj sine, što ukazuje na uzajamnu posevizaciju.

U obiteljskim situacijama najzastupljenija je materijalna prijelazna instrumentalna aktivnost $\mathrm{u}$ kojoj sudjeluju dječak kao sin i kao unuk, majka i otac. Dječak u ulozi unuka sadi drvo, dok u ulozi sina sudjeluje u nešto više aktivnosti, bilo sam, bilo sa ocem: otići (u školu), donositi (cvijeće mami), sipati (vodu u vazu), ući (u radnju, sa ocem), kupiti (poklon, sa ocem). Npr. A kad uđemo u radnju, kupimo joj i jedno i drugo. Majku susrećemo u tri materijalne prijelazne instrumentalne aktivnosti: staviti (cvijeće u vazu), kupiti (sinu kaput), slaviti (rođendan). Semiotičku prijelaznu aktivnost susrećemo u samo dva glagola: radovati se i htjeti. Npr. Raduj se kaputu (majka kaže sinu u pismu), Radujem se, puno se radujem cveću (mama piše u pismu sinu), Tata hoće lančić, a ja minđuše (otac i sin u trgovini razgovaraju o rođendanskom poklonu za majku/suprugu).

Ovdje je važno spomenuti i jednu zagonetku, prema kojoj se kćerka određuje prema muškom rodu, a glasi: “Tatino dete, mamino dete, a ničiji sin.” Odgovor je kćerka. 
U tablici ispod daje se prikaz kombinacija obiteljskih odnosa prikazanih u slikovnom i jezičnom sadržaju.

Tablica 2. Obiteljski odnosi u bukvaru iz 1974. godine

\begin{tabular}{|c|c|c|}
\hline Broj & DRUŠTVENI AKTERI & DRUŠTVENA AKTIVNOST \\
\hline 1. & MAJKA I SIN & 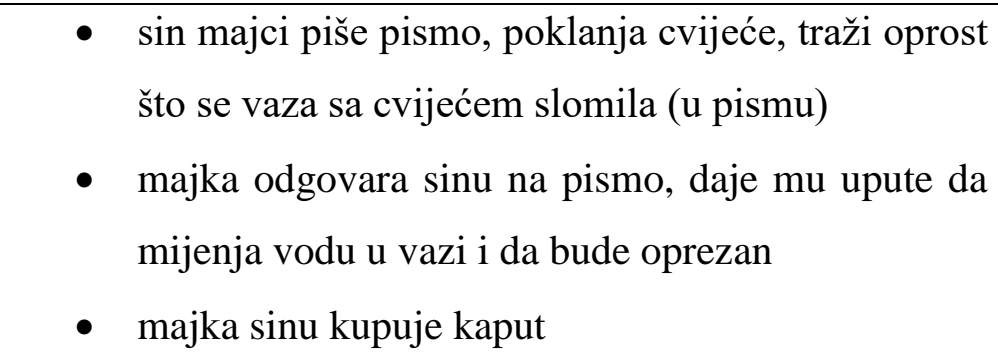 \\
\hline 2. & OTAC I SIN & - kupuju supruzi/majci poklon za rođendan \\
\hline 3. & MAJKA I KĆERKA & $\begin{array}{l}\text { - } \\
\text { - } \\
\text { - pletu jede zagrljaj } \\
\text { što radi mama radi i djevojčica) }\end{array}$ \\
\hline 4. & OTAC I KĆERKA & - nema odnosa \\
\hline 5. & BAKA I UNUKA & - $\quad$ nema odnosa \\
\hline 6. & BAKA I UNUK & $\begin{array}{l}\text { - u pjesmi D. Maksimović Novogodišnja čestitka } \\
\text { baki unuk bakine dane pozlaćuje, ublažava starost } \\
\text { (Neka ti se noći svake detinjstvo u san vrati, neka ti } \\
\text { unuk dane što idu ublaži, pozlati) }\end{array}$ \\
\hline 7. & DJED I UNUK & - $\quad$ sade drvo \\
\hline 8. & DJED I UNUKA & - nema odnosa \\
\hline 9. & BRAT I SESTRA & - nema odnosa \\
\hline 10. & OBITELJ & $\begin{array}{l}\text { - otac, majka, sinovi, kćeri, djed, baka, ujak, stric I } \\
\text { fijakerista): crtež koji predstavlja fotografiju sa } \\
\text { izleta na Frušku goru, slika } 72 \text {. }\end{array}$ \\
\hline
\end{tabular}




\subsubsection{Analiza slikovnog sadržaja u bukvaru iz 1996. godine}

Obiteljski odnosi i članovi obitelji prikazani su slikom na ukupno14 puta, uključujući i ilustraciju sažetog oblika bajke za djecu Crvenkapica, u kojoj se pojavljuje majka, djevojčica (Crvenkapica) i baka. Obiteljski akteri su prisutni u narativnim i konceptualnim reprezentacijama. Ove potonje su općenito dominantne u bukvaru iz 1996. godine, pa nisu mimoišli ni članove obitelji u analitičkim procesima i sl.

Majku susrećemo u narativnim reprezentacijama, u akcijskim procesima pri kojima vektor čini ruka u kombinaciji sa sljedećim predmetima: kuhača, pegla i košara s hranom. Kuhača i pegla su istovremeno i u funkciji sredstava kojima se ostvaruje akcijski proces. Ciljevi prema kojima je usmjerena su: kćerka, jastuk i kćerka kao Crvenkapica u okviru bajke. Kada je u ulozi pratnje, ona je to je kćerki i suprugu.

Dječak kao akter za vektor ima ruku i ruku koju produžuje ribički štap, koji je ujedno i sredstvo. Cilj kojem stremi je riba i automobil. Susrećemo ga jednom u ulozi reaktera, prilikom igre šaha sa ocem.

Kada je djevojčica akter, njezine ruke su vektori koje za produžetak imaju ili jedan cvijet, ili buket cvijeća ili košaru sa hranom (kada je djevojčica u ulozi Crvenkapice). Cilj prema kojem je usmjerena je natpis „mama“ sačinjen od cvijeća, majka, knjiga, a djevojčica Crvenkapice za ciljeve ima košaru sa hranom, vuka, bakinu kuću i baku. Kada čini pratnju, to je majci.

Interaktere susrećemo u primjeru kada se djevojčica i dječak, koji su ovdje brat i sestra drže za ruke (str. 63.). Oni su cilj jedno drugome, a vektori su njihove ruke.

Otac kao akter prisutan je kada igra šah sa sinom, njegova ruka je vektor, dok cilj predstavljaju šahovska figura i sin.

Budući da se kroz konceptualne reprezentacije iznosi najveći dio gradiva, tako su i članovi obitelji prisutni kao cjeline, dijelovi u okviru analitičkih procesa ili su ilustracije pojedinih rečenica. Posebno ćemo dati analizu slike 73 na kojoj je prikazana proširena obitelj na izletu.

Svi akteri se daju na dugačkoj udaljenosti iz dosljedno prednjeg horizontalnog kuta $i$ vertikalnoga na razini oka. Dugačka udaljenost čitaocu omogućuje uvid u raspored elemenata na slici i odnos aktera, ali mu se ne ovim odabirom ne nudi ostvarivanje bliskosti sa akterima. Oni ipak pripadaju svakodnevici čitaoca i jednaki su njemu i osobama iz njegovog životnog okruženja jer su prikazani iz prednjeg horizontalnog kuta i vertikalnog na razini oka. Kada je riječ o ostvarivanju interakcije sa čitaocem pogledom, zahtjev udružen sa osmjehom upućuju 
svi članovi proširene obitelji; majka, otac, sin, kćerka, djed i baka. Djevojčica i dječak su najzastupljeniji u zahtjevima koje prate osmjesi, on dok peca ribu, ona dok pokazuje knjigu koju je dobila i sl. Dječaka koji direktno gleda čitaoca viđamo i snuždenog izraza lica koji je potpomognut gestom upiranja prstom u igračku automobila (str. 49), naime bio je na sajmu automobila i umjesto pravog vozila, na poklon je dobio igračku. Kombinacijom direktnog pogleda, snuždenog izraza lica i gestom, on od čitaoca traži razumijevanje i suosjećanje.

Analiza modalnosti ovdje ne otkriva ništa što ranije nije bilo spomenuto u analizi slikovnih prikaza bukvara iz 1996. godine. Dakle, u dijelovima koji čine analitičke procese, modalnost je izrazito niska, nema prikaza nikakvog okruženja i budući je iza aktera samo bjelina, samim tim izostaje i dubina, detalji, kontekstualizacija itd. U ostalim dijelovima je niska, ali ipak slike daju nešto više detalja. Promatrajući garderobu, vidimo da majka na glavi nosi maramu dok obavlja kućanske poslove poput kuhanja i glačanja. Djed ima štap, što ukazuje na starost, i teškoće pri kretanju. Majka, kao i djevojčica ima cvijet.

Slika 73. pripada konceptualnim reprezentacijama, analitičkom procesu i predstavlja proširenu obitelj (majka, otac, djeca, djed i baka) na izletu. Vidjet ćemo kasnije, u analizi slike 76 na koji način je ista tema prikazana u narativnoj reprezentaciji. Raspored elemenata ovdje je postavljen na način da je gore cjelina, a dolje i to lijevo su dijelovi. Cjelinu čini slika obitelji na izletu i podijelit ćemo je na dva plana. Prvi plan je slika bliže nama, na kojoj su brat i sestra, a u drugom planu su članovi obitelji iza njih - lijevo su djed i baka, a desno majka i otac. Svi članovi obitelji su grupirani u muško-ženske parove i odvojeni su. Oni nisu akteri, niti reakteri, budući da ne postoje vektori koji bi nastali pokretom ruke ili linijom oka, ali su tako grupirani u parove jedni drugima pratnja. Bez obzira na odstupanje od uobičajenog obrasca karakterističnog za narativne reprezentacije, ovdje ćemo svakako analizirati ostale elemente: udaljenost, odabir kuta i uspostavljanje interakcije sa čitateljem pogledom, kao i modalnost, budući da iz navedenom dobivamo informacije o rodnim i međugeneracijskim odnosima. Svi su prikazani sa dugačke udaljenosti, iz prednjeg horizontalnog kuta i vertikalnog na razini oka. Ovakva obitelj pripada svijetu čitaoca bukvara i on je u mogućnosti povezati se sa svakim pojedinačnim članom budući da mu svi upućuju direktni pogled, koji je upotpunjen i osmijehom. Dječak i djevojčica imaju otvorenije osmjehe kojima pozivaju čitaoca da pogleda njihovu obitelj na izletu. Dijelove u ovom analitičkom procesu čine rečenice u kojima se ističe koji predmet koji član obitelji posjeduje. Pritom su izdvojeni otac, majka i djed. Majka ima cvijet, otac šešir, a djed štap. Pogledajmo modalnost, koja je nije na posve uobičajeni način niska, unatoč tomu što slika pripada analitičkim procesima. Obitelj se nalazi u šumi-parku koja nudi čistine, guste 
redove drveća i klupe za sjedenje, kao i stolove. Dječak i djevojčica stoje naslonjeni na jedan manji stol, a između njih je lopta koja najavljuje igru. Ona ima cvijet u kosi, a on kapu sa šiltom na glavi. Iza njih su roditelji koji stoje svako sa jedne strane stabla. Majka ima traku u kosi, koja je ovdje u funkciji modnog detalja - opuštena, ali funkcionalna frizura za dan u prirodi (podsjetimo se, kada obavlja kućanske poslove, kosu sveže maramom). U ruci drži predimenzionirani cvijet, koji je istaknut i u segmentu dijelova (dolje lijevo). Otac na glavi nosi neformalni šešir, koji je također posebno istaknut kao dio analitičkog procesa, dolje lijevo. Djed i baka su u drugom planu sa lijeve strane. On sjedi na klupi, podbočen o štap (istaknut u dijelovima analitičkog procesa), sijedih brkova i kose, dok ona stoji malo iza, ruku položenih na drveni stol na kojem je košara sa hranom i termos boca. Baka je pripremila hranu i piće za izlet i vjerojatno će za tim istim stolom obitelj i objedovati. Istaknut ćemo ovdje i paralelu predmeta koji nisu nužno istaknuti kao dijelovi analitičkog procesa, ali pripadaju ženskom dijelu obitelji. To je cvijeće (majka i djevojčica) i hrana, koju je pripremila baka. Na djedove pozne godine i teškoće s kretanjem ukazuje štap, dječak i otac imaju kapu/šešir na glavi što je tek dio odjevnog izbora, ali hrana i cvijeće pripadaju prirodi i čine vezu žene s njom. Veza žene i prirode bit će detaljno objašnjena u poglavlju Zaključak, ovdje se tek skreće pažnja na njezino postojanje kroz generacijsku paralelu djevojčica-žena-starija žena, tj. baka.

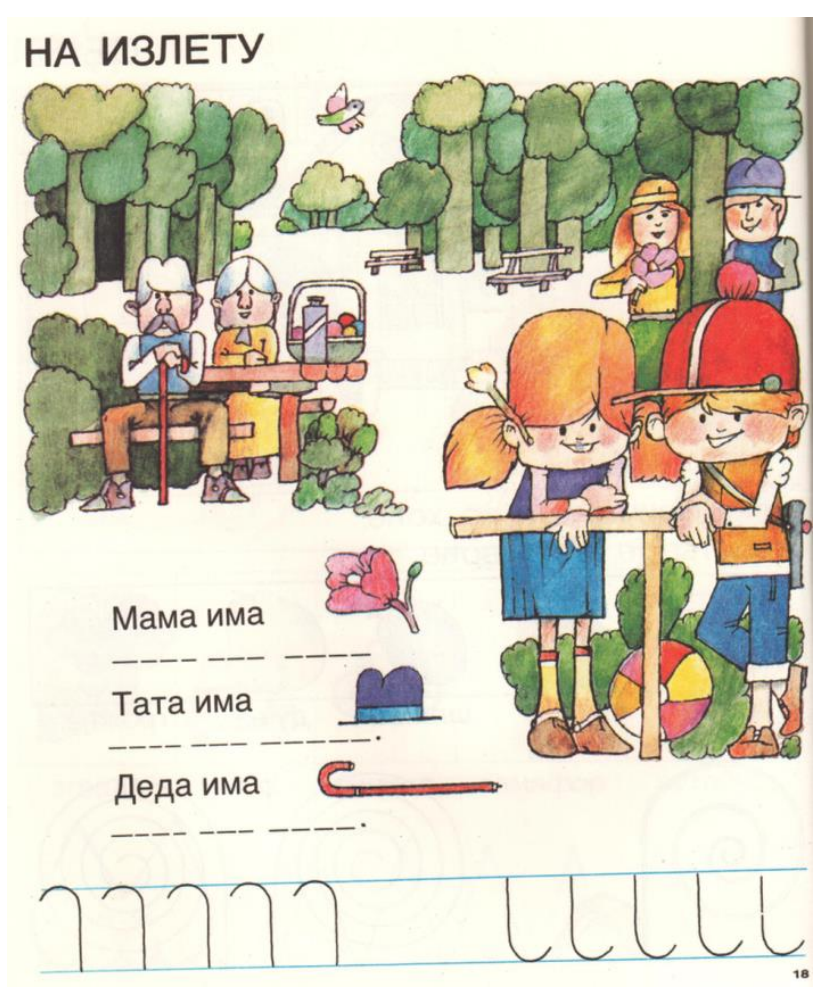

Slika 73. (Preuzeto iz Milatović, Ivković 1996.) 
Slika 74. prikazuje na šaljiv i hiperboličan način trenutke slobodnog vremena koje provode otac i sin. Oni su u ribolovu i ova slika pripada narativnim reprezentacijama, akcijskom procesu. Predstavlja spojen niz dva akcijska procesa, u kojem su akteri i otac i sin, ali sa različitim ciljevima. Otac kao akter za vektore ima ruke, dok mu je cilj sin, kojeg drži za noge i vuče ga prema sebi. Dječak u ulozi aktera za vektore ima ruke koje produžuje ribički štap, a cilj mu je riba, u ovom konkretnom slučaju veliki som. Otac je prikazan iz profila, što mu onemogućuje ostvarivanje direktnog pogleda sa čitaocem (ponuda), dok dječak upućuje zahtjev uz osmijeh. Traži pažnju čitaoca, izaziva osmjeh kod njega i pokazuje mu komičnu situaciju u kojoj se našao pecajući s ocem, koji ga i spašava. Čitav prizor dan je sa dugačke udaljenosti, što omogućava pregled ovog niza akcijskih procesa. Oba aktera su prikazana iz prednjeg horizontalnog kuta i vertikalnog na razini oka, što ne znači da je ovakva ribička situacija dio svakodnevice čitaoca bukvara, ali se sugerira ovakvo zajedničko provođenje vremena sa ocem. Kada je riječ o modalnosti, ona je izrazito niska, čitav crtež odlikuje minimalizam izraza, prikazano je tek nužno. Okruženje je na razini skice, obala na kojoj stoji otac je zapravo bjelina, koja se spaja sa pozadinom, vodu čini nekoliko ovlaš nacrtanih valova, u pozadini je jedan žbun koji predstavlja prirodno okruženje. Som je naravno predimenzioniran, budući da je veći od samog dječaka, što također snižava modalnost.

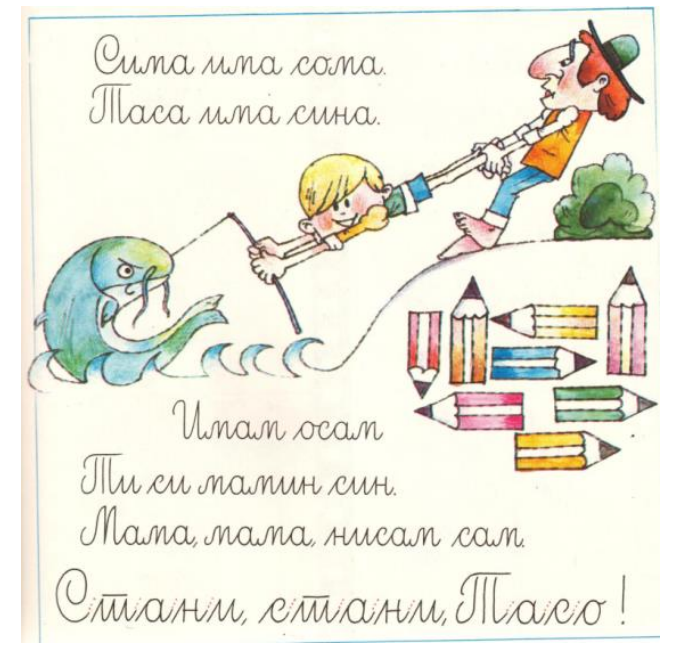

Slika 74. (Preuzeto iz Milatović, Ivković 1996.)

Na slici 75. vidimo najstarijeg muškog člana proširene obitelji - djeda, ali u konceptualnoj reprezentaciji, u analitičkom procesu. Cjelina (lik djeda koji u svakoj ruci drži po jedno slovo) je i ovdje pozicionirana gore, a dijelovi (riječi koje treba dopisati istaknutim slovima iz cjeline) su dolje. Prikazan je sa široke udaljenosti što ga dobro pozicionira u prostoru u odnosu na 
kartice sa slovima koje drži u rukama i riječi za dopisivanje, koje su mu uz noge. Odabir kuta je uobičajen za svrstavanje prikazanoga u svijet čitaoca, prednji horizontalni kut, i uspostavljanja odnosa jednakosti s njim - vertikalni na razini oka. Interakcija sa čitaocem je ostvarena direktnim pogledom (zahtjev). Kod modalnosti, treba naglasiti da djed i ovdje ima dugačke sijede brkove, ali i da nosi prsluk što se npr. u bukvaru iz 1965. obilježavalo aktere iz ruralnih predjela. Vidjet ćemo istu lekciju u bukvaru iz 2011. godine u sasvim drugačijem prikazu djeda, ali sa istim odjevnim obilježjem.

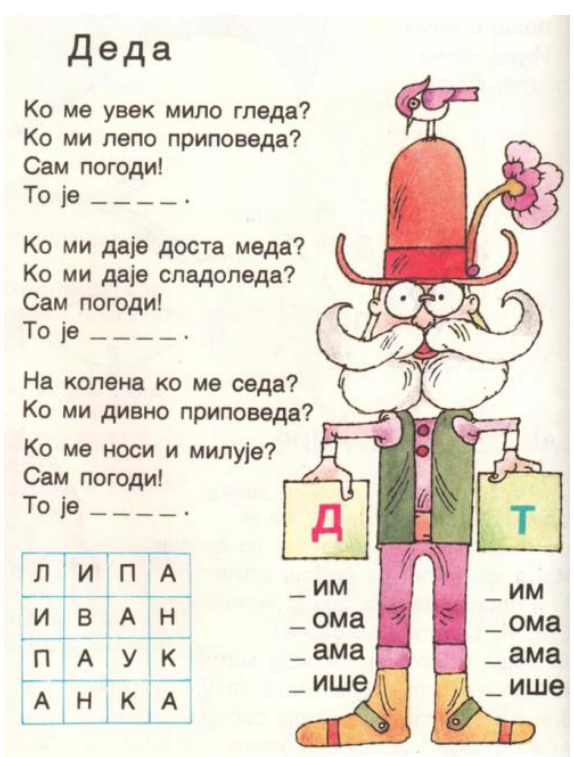

Slika 75. (Preuzeto iz Milatović, Ivković 1996.)

\subsubsection{Analiza jezičnog sadržaja u bukvaru iz 1996. Godine}

Društveni akteri su procesom relacijske nominacije dobili sljedeće nazive: nana (baka), sestra, tata, mama, deda, sin i kći. Neki od članova obitelji imaju samo osobna imena (poluformalna nominacija), pa se tako djevojčice koje su sestre zovu Jana i Jasna, djevojčica koja je samo kćerka zove se Maša i Maja, brat i sestra su Milica i Vlado. Dobnu klasifikaciju susrećemo u imenici djeca, koja se odnosi na dječaka i djevojčicu sa imenima Pera i Vera. Tjelesno je identificirana samo djevojčica maša i to kao mala Maša, koja se izgubi u šumi pa je traže roditelji. Kao i u bukvaru iz 1974. godine, imamo primjer posvojne zamjenice moj/moja, koju ovdje koristi samo dječak referirajući se na svoje roditelje (npr. moga tatu, moju maтu).

U materijalnoj neprijalaznoj aktivnosti sudjeluju samo djevojčice i to u jednom primjeru koji glasi ustaju rano (sestre Jana i Jasna). 
Primjeri materijalne prijelazne instrumentalne aktivnosti pokazuju da samo djevojčice koje su sestre ili kćerke, kao i majka, sudjeluju u njima pa se tako na djevojčice odnose glagoli: nositi (maramu), imati (trotinet, auto), nositi (knjigu), otići (u šumu), naći (jagode), sjesti (u košaru). Majka je ostala u domenu aktivnosti vezanih uz kuhinju i to kroz glagol napraviti, koji se odnosi na tortu. Npr. Jana i Jasna su sestre. One nose marame. U šumi je našla jagod; Maša je sela u košaru.

Materijalnu prijelaznu interaktivnu aktivnost roditelji usmjeravaju na kćerku u jednom primjeru našli malu Mašu (majka i otac su pronašli u šumi kćerku koja se izgubila), a djed na unuka u glagolima: gledati, milovati, pripovijedati.

Semiotička prijelazna aktivnost prisutna je u svega tri primjera: misliti (majka misli na sina), smiješiti se (majka sinu) i voljeti, što je pak aktivnost koju dječak usmjerava prema članovima svoje obitelji, majci, ocu i sestri

U tablici ćemo prikazati sve kombinacije obiteljskih odnosa zastupljenih u slikovnom i jezičnom sadržaju.

Tablica 3. Obiteljski odnosi u bukvaru iz 1996. godine

\begin{tabular}{|c|c|c|}
\hline Broj & DRUŠTVENI AKTERI & DRUŠTVENA AKTIVNOST \\
\hline 1. & MAJKA I SIN & $\begin{array}{l}\text { - odlaze na sajam automobila } \\
\text { - majka pjeva malom sinu, misli stalno na njega, } \\
\text { miluje ga, smiješi mu se }\end{array}$ \\
\hline 2. & OTAC I SIN & $\begin{array}{l}\text { - otac uči sina igrati šah } \\
\text { - } \quad \text { pecaju (otac ga spašava da ga velika riba ne povuče } \\
\text { u vodu) }\end{array}$ \\
\hline 3. & MAJKA I KĆERKA & $\begin{array}{l}\text { - djevojčica od cvijeća pravi natpis "mama" } \\
\text { - djevojčica daje majci cvijet } \\
\text { - djevojčica kao Crvenkapica od majke dobiva } \\
\text { košaru sa hranom za baku }\end{array}$ \\
\hline 4. & OTAC I KĆERKA & - odlaze na sajam knjiga \\
\hline 5. & BAKA I UNUKA & - kao Crvenkapica, donosi baki hranu \\
\hline 6. & BAKA I UNUK & - nema odnosa \\
\hline 7. & DJED I UNUK & $\begin{array}{l}\text { - djed unuka milo gleda, pripovijeda mu, daje mu } \\
\text { med, sladoled, posjeda u krilo, nosi ga i miluje }\end{array}$ \\
\hline
\end{tabular}




\begin{tabular}{|l|l|ll|}
\hline 8. & DJED I UNUKA & nema odnosa \\
\hline 9. & BRAT I SESTRA & $\bullet$ & on nju drži za ruku, kao da ju vodi, nosi \\
& SESTRE/BRAĆA & predimenzionirani cvijet str 63 (interakteri su) \\
& & $\begin{array}{l}\text { sestre nose marame, imaju slične igračke auto i } \\
\end{array}$ & trotinet, bude se rano zbog odlaska u školu \\
\hline 10. & OBITELJ & $\begin{array}{l}\text { Roditelji, djeca (sin i kćer), djed i baka; idu na izlet } \\
\end{array}$ & $\begin{array}{l}\text { Otac, majka, kćer: djevojčica se izgubila u šumi, } \\
\end{array}$ \\
& & roditelji je pronalaze. \\
\hline
\end{tabular}

\subsubsection{Analiza slikovnog sadržaja u bukvaru iz 2011. godine}

Slikovni sadržaji koji prikazuju obiteljske odnose i članove obitelji prisutni su u ukupno 22 lekcije, uključujući i ilustraciju sažetog oblika bajke za djecu Crvenkapica, kao i u bukvaru iz 1996. godine. Treba naglasiti i da se neki prikazi sastoje od više povezanih slika, koje ovdje nisu zbrajane pojedinačno, jer pripadaju istim tematskim cjelinama. Budući da u ovom bukvaru $\mathrm{u}$ odnosu na prethodni narativne reprezentacije dominiraju nad konceptualnim, isto je i sa prikazima članova obitelji i obiteljskih odnosa. Akcijski i reakcijski procesi su najprisutniji. Kada je majka akter u akcijskom procesu, vektor joj čini ruka, sama ili produžena kuhačom ili košarom sa hranom. Ciljevi prema kojima je usmjerena su knjiga, lonac, jelo, kćerka i sin. Djevojčica za vektore pak ima i ruke i noge, ciljevi su joj košara sa hranom, bakina kuća, vuk, jabuka. Susrećemo je i u ulozi pratnje dječaku s kojim gleda televizijski program (slika 79). Dječakove ruke su također vektori, ali su potpomognuti daljinskim upravljačem i olovkom, dok su njegovi ciljevi televizor, pismo i posuda sa nadjevom za tortu. Članovi obitelji u ovom bukvaru pojavljuju se i kao interakteri u akcijskom procesu, gdje su jedni drugima cilj. To se odnosi na majku sa sinom i kćeri, oca i majku sa sinom u šetnji (slika 78) i majku i kćer kroz bajku o Crvenkapici. U slikovnom prikazu Crvenkapice također susrećemo i reakcijske procese u kojima sudjeluje Crvenkapica kao reakter gledajući vuka, ali su reakteri i mama i djevojčica koje gledaju knjigu, baka i mama gledajući tatu sa slušalicama i dječak koji također gleda knjigu. Djevojčica je u ulozi reaktera dok gleda brata koji jede nadjev za tortu, na slici 80, koju ćemo posebno analizirati. U ovom bukvaru, kod prikaza članova obitelji također ima neprijelaznih narativnih struktura i to u situacijama gdje dječak i majka spavaju, otac i majka sjede i sl. Obitelj na okupu prikazuje se uvijek sa dugačke udaljenosti, dok je srednja udaljenost određena za ilustracije koje se odnose na npr. pojedine rečenice unutar lekcije. Zahtjev, kojim bi se uspostavila interakcija sa čitaocem bukvara izostaje u svim primjerima, osim u onom iz 
bajke, kada Crvenkapica nosi baki hranu i upućuje pogled čitaocu. Sve obiteljske situacije prikazane su iz prednjeg horizontalnog kuta i vertikalnog na razini oka, što čitaocu omogućava lako poistovjećivanje sa prikazanim prizorima iz obiteljskog života. Po pitanju modalnosti, ovdje ćemo se osvrnuti na garderobu i neke tjelesne osobine. Prvi put od 1965. vidimo osobu ženskog spola u hlačama, koje su do sada u bukvaru bile isključivo muški odjevni predmet. Majka je odjenula hlače za izlet (slika 76) i trenirku za šetnju parkom (slika 78). Prilikom kuhanja, kao i u prethodnim bukvarima, nosi zaštitnu pregaču. Primjećuje se i modernizacija u pravcu skraćivanja kose osoba ženskog spola, jer majka i baka imaju kraću kosu. Djed ipak zadržava svoje sijede brkove koji su posebno bujni na slici 81 koju ćemo posebno analizirati. Štap za hodanje ni ovdje ne izostaje.

Slika 76 prikazuje proširenu obitelj na izletu i možemo je usporediti sa slikom 73, na kojoj je ista tema obrađena bez akcijskog procesa. Slika 76 kao cjelina također pripada konceptualnim reprezentacijama, analitičkom procesu u kojem je cjelina pozicionirana gore (čini ju više zasebnih akcijskih i reakcijskih procesa), i dijelovi koji se nalaze dolje u obliku rečenica koje dopunjavaju crteži predmeta. Rečenice su identične onima sa slike 73. Ovu sliku ćemo također podijeliti na dva plana. U prvom su dječak sa ribičkim štapom i djed, a u drugom roditelji i dječak koji lovi leptira. Djed je reakter, budući da linijom oka formira vektor koji je usmjeren prema plovku na ribičkom štapu kojeg drži dječak. Dječak je dakle pojava ili fenomen. Majka i otac koji sjede na dekici također pripadaju reakcijskom procesu. Ona rukom prima šalicu (pojava), na što on usmjerava pogled što ga čini reakterom. Dječak iza njih je akter, njegova ruka je vektor koji za produžetak ima mrežu za hvatanje leptira (ujedno je i sredstvo). Cilj prema kojem je usmjeren ovaj akcijski proces je leptir. Za psa možemo reći da funkcionira kao pratnja roditeljima iz reakcijskog procesa. Čitava slika je prikazana iz dugačke udaljenosti dajući nam informacije o rasporedu aktera i reaktera, kontekstu i okruženju. Prizor obitelji na izletu dan je iz prednjeg horizontalnog kuta i vertikalnog na razini oka. Svi akteri i reakteri pripadaju svijetu čitaoca bukvara, mogu biti dio njegovog života i svakodnevice i on se s lakoćom može poistovjetiti sa prikazanim. Interakcije direktnim pogledom ovdje nema (ponuda), što je i sasvim očekivano budući da su na slici prisutna dva reakcijska procesa i jedan akcijski, kod kojeg također izostaje zahtjev. Ukoliko usporedimo članove obitelji na izletu 1996. i 2011. vidimo da je struktura proširene obitelji drugačija. Umanjena je za jednog člana - baku i umjesto djevojčice, prisutan je još jedan dječak. Modalnost je dosta visoka za jedan bukvarski crtež, koji ovdje ima i dubinu i detalje, okruženje i kontekst. Bjeline su nepostojeće, što posebno dolazi do izražaja ukoliko se prisjetimo praznog prostora na slici 73., u odnosu na detalje na 
slici 76 u oslikavanju neba i oblaka u pozadini, šume u daljini ili npr. nijansiranje zelene boje livade koje je svjetlija na dijelovima koji su osunčani. Trava je tamnija bliže stablu, koje stvara sjenu i hlad. Svi članovi obitelji odjeveni su u suvremenu odjeću prikladnu za provođenje slobodnog vremena u prirodi. Roditelji su u trenirkama, a poseban izuzetak čini majka koju prvi put vidimo moderno odjevenu, bez do sada obaveznog obitavanja u suknjama ili haljinama. Dječak sa ribičkim štapom kapu šiltericu nosi na način da je šilt okrenut na stražnju stranu glave, što je utjecaj suvremene američke popularne kulture. Podsjetimo se, dječaci u urbanim sredinama u bukvaru iz 1965. nose kape sa šiltom, doduše sigurno izražene i od drugih materijala, ali ne u ovakvoj varijaciji. Djed ovdje na sebi ima šešir, jaknu, hlače i cipele i neizostavno štap u ruci. Vidjet ćemo djeda kasnije na slici 81 drugačije odjevenog, sa većim i potpuno sijedim brkovima, koji ostaju njegov zaštitni znak. Usporedbom okruženja na slici 73 i 76, uočavamo da su odabrane i različite lokacije za mjesto izleta. Na slici 73, to je uređena šuma-park u kojoj postoje klupe i stolovi na koje se može postaviti hrana, dok je na slici 76 obitelj u neuređena priroda, jer postavljaju hranu na deku, na kojoj ujedno i sjede, nema klupa, dječak peca na rijeci ili jezeru i nema vidljivih znakova uređenja. Može se zaključiti da je ovo gradska obitelj na cjelodnevnom izletu izvan urbane sredine. Da će na ovom mjestu provesti najveći dio dana, možemo iščitati iz njihovog smještanja u hladovinu i iz količine namirnica. Na slici 73 hrana se svodi tek na sadržaj jedne košare, dok na slici 76 vidimo i veliku termos bocu, šalice, kutiju s poklopcem, košaru, voće, i još dio jedne posude koja se nalazi iza košare. Cijeli prizor izgleda kao cjelodnevni obiteljski piknik u prirodi u dane vikenda, koji je u današnje vrijeme uobičajeni bijeg od gradske vreve i užurbanog načina života. 


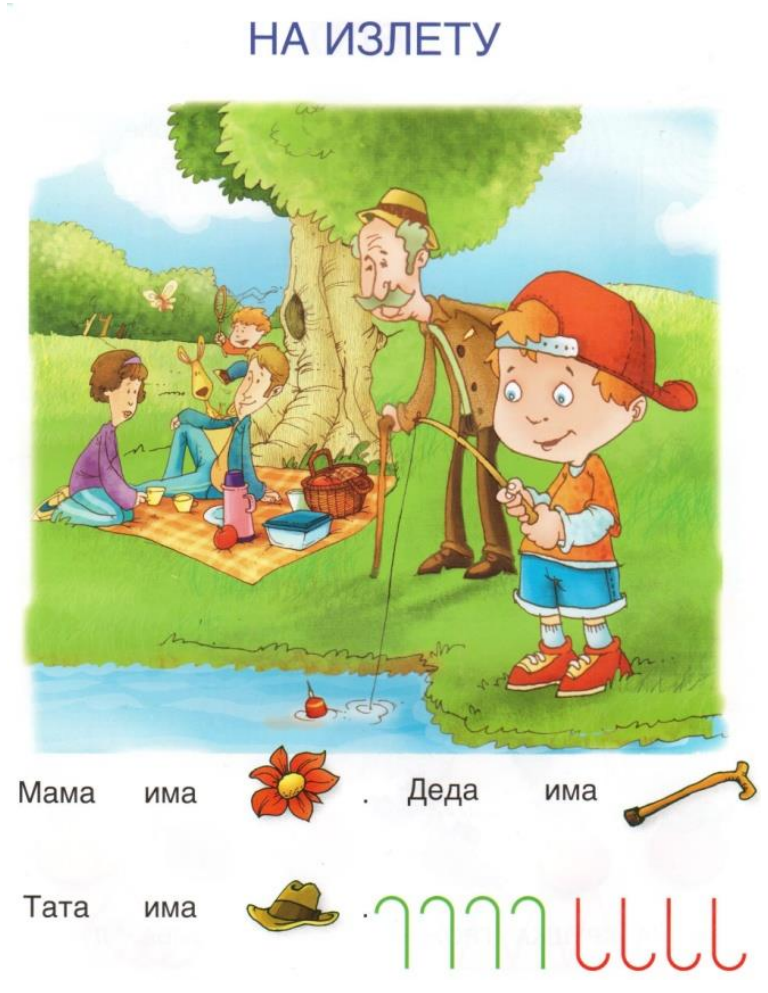

Slika 76. (Preuzeto iz Milatović, Ivković 2011.)

Slike 77 i 78 analizirat ćemo usporedno s obzirom na to da je na obje prikazan akcijski proces u kojem su članovi obitelji reakteri i da obje predstavljaju slobodno vrijeme provedeno sa obitelji. Na slici 77 je majka sa sinom i kćeri na kauču. Interakteri su majka i sin, kao i majka i kćer. Ona sjedeći u sredini sa svakom rukom (vektori) grli po jedno dijete, dok dječak i djevojčica grle nju. Između brata i sestre ne postoji akcijski proces, jer su ruke usmjerene samo prema majci. Potpuno drugačiji raspored vidimo na slici 78, gdje je dječak smješten na središnju poziciju i svakom rukom drži jednog roditelja. Stoga su ovdje interakteri majka i sin i otac i sin, a između majke i oca također ne postoji akcijski proces. Iako se na slici 77 ne vidi cijela majčina figura, možemo reći da je obitelj ipak prikazana sa dugačke udaljenosti, jer su dječak i djevojčica vidljivi u cjelini, a kod nje izostaju samo stopala. Možemo sagledati njihov raspored u prostoru, tj. na kauču koji dijele. Obitelj na slici 77 također je dana sa dugačke udaljenosti, uz širi prikaz okruženja u kojem se nalaze. Majka sa djecom na kauču prikazana je iz prednjeg horizontalnog kuta i vertikalnog na razini oka. Ovaj prizor u potpunosti pripada svijetu čitaoca bukvara i on se sa lakoćom može povezati sa ovakvom obiteljskom dokolicom, pri čemu je izjednačen sa svim prikazanim članovima obitelji, budući da nema iskazanog odnosa moći. Pozicioniranje članova obitelji u odnosu na horizontalni kut je ponešto drugačija na slici 78 jer je dječak prikazan iz prednjeg horizontalnog kuta, a roditelji iz djelomično kosog horizontalnog kuta. Djeca u pješčaniku sa lijeve strane također su dana iz prednjeg horizontalnog kuta, što 
navodi na zaključak da samo djeca pripadaju svijetu čitaoca bukvara, dok su odrasli, makar to bili i roditelji, dani na distanci pa možemo reći da djeca ne pripadaju svijetu odraslih. Vertikalni kut je na slici 78 također na razini oka, čime prikazani reakteri ne uspostavljaju odnos moći sa čitaocem. Na obe slike prisutna je ponuda, kada je riječ o uspostavljanju interakcije sa čitaocem pogledom. Djevojčica na slici 77 čak ima zatvorene oči, što je znak predaje i povjerenja prema majci. Modalnost je viša na slici 78 budući da je detaljnije i sa više dubine prikazano okruženje. Na slici 78 vidimo samo kauč, ovlaš obojan, koji se bojom stapa sa zidom koji je iza. Prevladava žuta boja, koja sugerira toplinu i sigurnost obiteljskog doma i zapravo bi drugi detalji ovdje bili suvišni. Na slici 78 jasno je da obitelj u šetnji prolazi pored dječjeg igrališta na kojem je tobogan, ljuljačka, pješčanik, vidi se čak i klupa u pozadini, kao i obronci brda. Ovo daje dubinu i perspektivu crtežu. Prikaz detalja je također dosta razrađen i promišljen, pa imamo uvida i u igračke koje su djeca iz pješčanika donijela na igralište - bicikl i lopta, vidimo da otac oko pasa ima torbicu koja pripada današnjici, oba roditelja su odjevena sportski, u trenirke, a majka ima čak izrazito kratku kosu u odnosu na frizuru iz starijih bukvara. U daljini, pomalo stapajući se sa plavim horizontom, naziru se stambene zgrade iz kojih su vjerojatno njih troje i krenuli u šetnju.
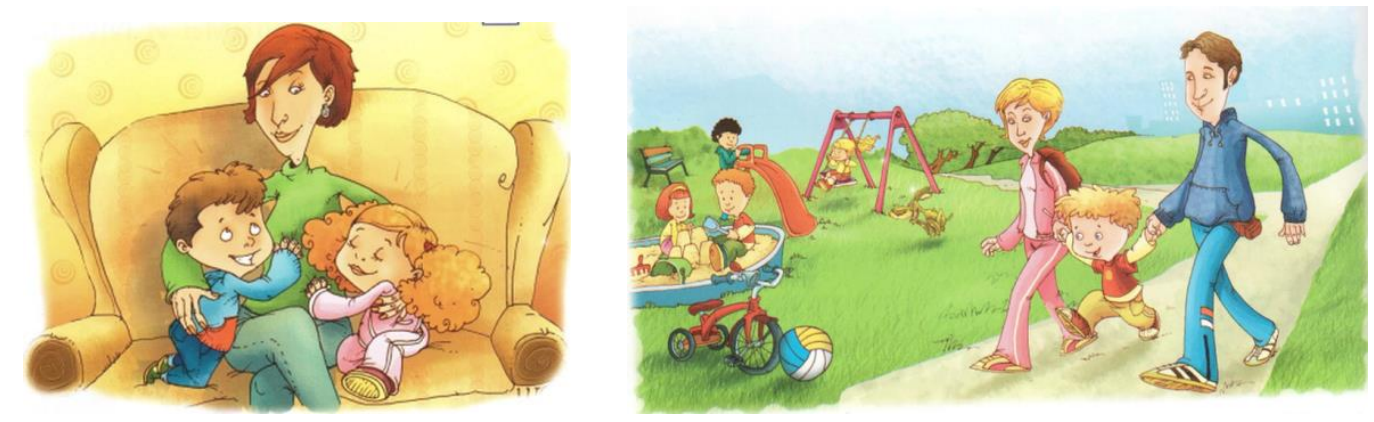

Slika 77. (Preuzeto iz Milatović, Ivković 2011.)

Slika 78. (Preuzeto iz Milatović, Ivković 2011.)

Slike 79 i 80 također ćemo analizirati paralelno, budući da na obje vidimo brata i sestru u trenucima slobodnog vremena u obiteljskom domu. Slika 79 prikazuje brata i sestru kako zajedno sjede i gledaju televizijski program. Ovo je akcijski proces u kojem je dječak akter, vektor čini njegova ruka sa daljinskim upravljačem, koji je ujedno i sredstvo, dok je televizor cilj. Djevojčica je u ulozi pratnje, budući da od nje ne kreće vektor, niti ona pokreće neku vrstu aktivnosti. Slika 80 prikazuje reakcijski proces u kojem je djevojčica reakter i možemo pratiti kako njezin pogled gradi vektorsku liniju koja ide prema dječaku koji iz posude jede nadjev od 
torte (slika ilustrira tekst Neće uvek da bude prvi, str. 109), što njega čini pojavom ili fenomenom. Ukoliko promatramo njega izdvojenoga, on može biti akter koji za vektore ima obje ruke i dva različita cilja. Jedan je djevojčica na koju pokazuje prstom, a drugi je posuda sa nadjevom od torte. Brat i sestra na slici 79 prikazani su na dugačkoj udaljenosti, a na slici 80 na srednjoj udaljenosti, dok je odabir horizontalnog i vertikalnog kuta na obje slike identičan. Prednji horizontalni kut svrstava ih u svakodnevicu i stvarnost čitaoca bukvara, a vertikalni na razini oka prikazanog brata i sestru izjednačava sa čitaocem. Prikazane situacije čine dio čitaočevih obiteljskih okolnosti. Ni na jednoj slici dječak i djevojčica ne uspostavljaju direktnu interakciju sa čitaocem pogledom, pa je kod oboje prisutna samo ponuda. Oni ga ne obvezuju, niti traže komunikaciju s njim. Modalnost je niska na obje slike, o okruženju saznajemo minimalno, osim što iz slike 79 možemo iščitati doba dana. Naime, zelena pozadina sa sjenama zaključujemo da je večer i da djeca gledaju televizijski program pred odlazak na spavanje. Od namještaja je prikazan samo kauč/fotelja, televizor i klupa na kojem se nalazi. Zidovi nisu ukrašeni slikama, ne vidi se tepih, prozor, police i slično. Slika 80 daje još manje informacija o okruženju, tj. ostavalja otvorenim pitanje prostorije u kojoj se odvija događaj. Pozadina je nijansirano žuta, ali se naziru obrisi torte i naranče, pa možemo zaključiti da su djeca u kuhinji. Djevojčica na ovoj slici u naručju drži plišanog medvjedića što ukazuje na to da je mlađa od brata.
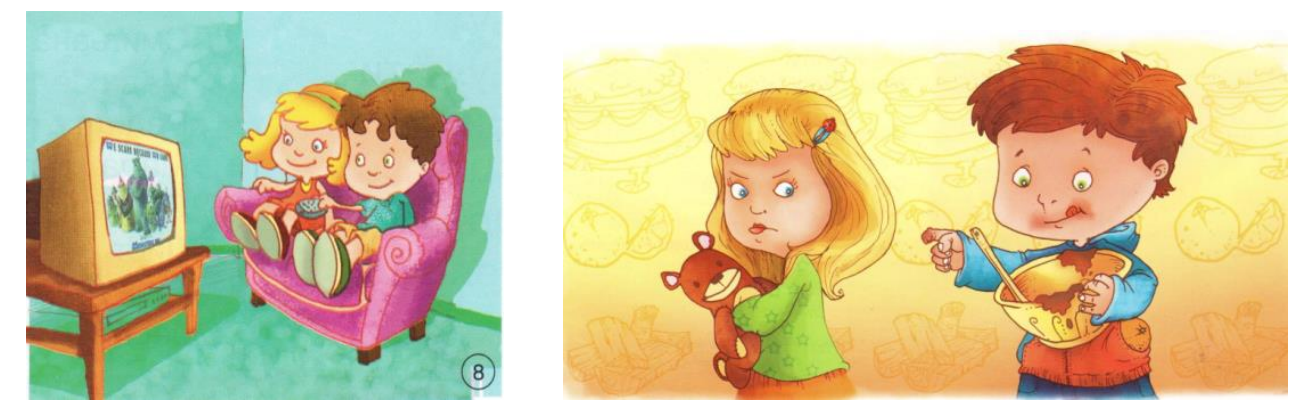

Slika 79. (Preuzeto iz Milatović, Ivković 2011.) Slika 80. (Preuzeto iz Milatović, Ivković 2011.)

Slika 81 prikazuje interakciju unuka i djeda, koji su ovdje interakteri budući da su njihovi vektori ruke kojima dodiruju jedno drugo. Djed pokroviteljski dječaku stavlja ruku na glavu dok mu dječak sjedi u krilu. Unatoč tomu što kod prikaza djeda izostaje donji dio potkoljenica i stopala, a dječak se vidi u cijelosti, svrstat ćemo ovu sliku među one dane iz dugačke udaljenosti. Obojica su prikazana iz prednjeg horizontalnog kuta i vertikalnog na razini oka. Ovakva vrsta interakcije i druženja sa djedom u potpunosti pripada svijetu čitaoca bukvara i prikazani članovi obitelji nad čitaocem ne uspostavljaju odnos moći. Direktnog pogleda nema (ponuda), jer obojica gledaju jedan drugoga. Kod analize modalnosti pažnju ćemo usmjeriti na 
prsluk kao izdvojen odjevni predmet. Naime, vidjeli smo u starijim bukvarima, posebno u onome iz 1996. da akteri iz ruralnih krajeva u garderobi imaju dijelove narodne nošnje, poput dugačkih bijelih košulja, prsluka, kapa i sl. Ovaj prsluk i košulja također mogu pripadati narodnoj nošnji, tim prije što prsluk ima obrub detalje koji izgledaju kao vez. Ako ćemo pratiti uspostavljenu liniju prema kojoj elementi narodne nošnje aktere smejštaju u prostor sela, ili određuju njihovu pripadnost selu, ovaj djed također tu priada. Tim prije što je vidljivo da sjedi na tronošcu. Neupitna je njegova sličnost sa Vukom Karadžićem (slika 4 i slika 8), zbog podudarnih crta lica, dugih sijedih brkova i odjeće koja sadrži elemente narodne nošnje. Kod Vuka Karadžića je to uglavnom bio fes, dok djed na sebi ima vezom ukrašen prsluk. Sličnost ovog djeda sa Vukom Karadžićom možemo dodatno podvući i time da ova slika ilustrira pjesmicu Deda u kojoj je naglašeno da djed lijepo pripovijeda unuku (Ko mi lepo pripoveda? Sam pogodi! To je deda. str. 66), dakle on je netko ko zna puno priča, kao što je i Vuk Karadžić puno narodnih umotvorina znao i zapisao.

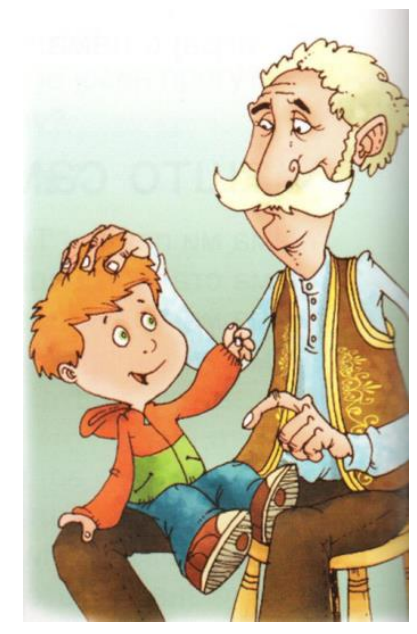

Slika 81. (Preuzeto iz Milatović, Ivković 2011.)

\subsubsection{Analiza jezičnog sadržaja u bukvaru iz 2011. godine}

Društveni akteri kao članovi obitelji relacijski su identificirani kao mama i majka, tata, baba, deda, brat i sestra. Sva djeca su procesom poluformalne nominacije dobili sljedeća imena: Mima, Toma, Jana, Jasna, Nena, Ljiljana, Smiljana, Jelena, Maša, Petar, Mira, Goran, Milica i Vlado i Cica. Kada je riječ o odraslima, prisutno je samo ime Tominog oca, koji se zove Sima. Tjelesne identifikacije odnose se na djevojčice: mala Jelena, mala Maša, a dobne na oba spola upotrebom imenica dječak i djevojčica. Susrećemo jedan primjer funkcionalizacije majke, koja ima ulogu carice u snu u kojem djevojčica sanja da je princeza. U toj domeni sna su prisutne 
još dvije funkcionalizacije dječaka i djevojčicu, koji su ovdje princ i princeza, ali su i tjelesno identificirani: lepa princeza, mladi princ.

Od društvenih aktivnosti u kojima sudjeluju članovi obitelji, najzastupljenije su materijalne prijelazne instrumentalne aktivnosti i materijalne prijelazne interaktivne. Kao društveni akter, otac je najmanje prisutan u bilo kojoj vrsti aktivnosti, pa ga susrećemo samo u materijalnim prijelaznim instrumentalnim aktivnostima i to u dva primjera: uzeti (telefon), montirati (gumu). Majka je u toj vrsti aktivnosti zastupljenija i to kroz niz glagola: prati (sudove), ući (u kćerkinu sobu), razmaknuti (zavjese), donijeti (vjenčanicu, u primjeru kada je majka carica, a djevojčica princeza), napraviti (tortu). Djevojčica, koja je sestra i kćerka, prisutna je u sljedećim materijalnim prijelaznim instrumentalnim aktivnostima: nositi (maramu), imati (auto, romobil), otići (u šumu), naći (jagode), sjesti (u košaru), listati (knjigu), istrčati (napolje), pružati (dlanove), uhvatiti (pahulje), najesti se (torte). Dječak je poput oca, prisutan tek kroz dvije vrste ovog tipa aktivnosti: pisati (pismo), čitati (knjigu). Npr. A onda, jednog jutra, mama uđe u sobu $i$ razmače zavese. Mira se odmah obuče i istrča napolje. Radosno pruža dlanove da uhvati krupne, bele pahulje; Milena se najela torte.

Materijalna prijelazna interaktivna aktivnost karakterizira samo dječaka i djevojčicu, njega kroz glagol pisati (pismo), a zajedno su prisutni kroz sljedeće glagole: moliti (majku), igrati i pjevati. Djed, kao i u bukvaru iz 1996. Sudjeluje u sljedećim aktivnostima: gledati (unuka), pripovijedati (unuku), davati (med), milovati (unuka). Na djevojčicu, koja je kćerka, odnose se sljedeći primjeri: pitati (majku), donijeti (snijega majci), sresti (princa), probuditi (brata), obući (sebe). Majka je kroz ovu vrstu aktivnosti u interakciji sa svojom djecom: objašnjavati (kćeri), reći (Cici, kćerki iz sna koja je princeza), ustati npr. Ustani kćeri, da pustiš stoku! i negirani oblik glagola svađati se u obraćanju djeci: Ne svađajate se!

Materijalna neprijelazna aktivnost odnosi se na oca, baku i majku to u glagolu viknuti. Npr. Zazvonio telefon, tata viknu: „To je on! Prijatelj me traži“; Mama viknu: „To je on! To me krojač traži! “

Semiotička neprijelazna aktivnost također nije česta i prisutna je samo u glagolu ustajati se, u značenju buditi se. Odnosi se na djevojčice koje su sestre i na majstora Mitu, koji je otac jednog dječaka.

Semiotička prijelazna aktivnost obuhvaća dječaka koji je brat u dva primjera i oba aktivnost prenose na sestru: naljutiti se (na sestru), voljeti (Volim mamu, tatu i sestru.). Na majku se 
odnose aktivnosti misliti (na svoje dijete), smiješiti se (djetetu), a na djevojčicu ugledati (jabuku) i zaljubiti se (u princa).

U tablici ćemo prikazati sve kombinacije obiteljskih odnosa zastupljenih u slikovnom i jezičnom sadržaju.

Tabela 4. Obiteljski odnosi u bukvaru iz 2011. godine

\begin{tabular}{|c|c|c|}
\hline Broj & DRUŠTVENI AKTERI & DRUŠTVENA AKTIVNOST \\
\hline 1. & MAJKA I SIN & $\begin{array}{l}\text { - Odlaze na sajam automobila } \\
\text { - Razgovaraju o pismu koje sin piše, ona nadgleda } \\
\text { proces }\end{array}$ \\
\hline 2. & OTAC I SIN & - otac uči sina igrati šah \\
\hline 3. & MAJKA I KĆERKA & $\begin{array}{l}\text { - } \text { čitaju zajedno knjigu i razgovaraju } \\
\text { - Majka Crvenkapici daje hranu za baku } \\
\text { - Odlaze na sajam automobila } \\
\text { - ljetuju zajedno } \\
\text { - kćerka nosi maminu maramu } \\
\text { - dok majka pere sudove razgovara sa kćeri, } \\
\text { - odgovara na njezina pitanja } \\
\text { majka budi kćerku }\end{array}$ \\
\hline 4. & OTAC I KĆERKA & $\begin{array}{l}\text { - } \quad \text { odlaze na sajam knjiga } \\
\text { - ona nosi očev sat }\end{array}$ \\
\hline 5. & BAKA I UNUKA & - kao Crvenkapica nosi baki hranu \\
\hline 6. & BAKA I UNUK & - nema odnosa \\
\hline 7. & DJED I UNUK & $\begin{array}{l}\text { - djed unuka milo gleda, pripovijeda mu, daje mu } \\
\text { med, sladoled, posjeda u krilo, nosi ga i miluje }\end{array}$ \\
\hline 8. & DJED I UNUKA & - nema odnosa \\
\hline 9. & $\begin{array}{l}\text { BRAT I SESTRA } \\
\text { SESTRE/BRAĆA }\end{array}$ & $\begin{array}{l}\text { - Brat i sestra: zajedno gledaju televizijski program } \\
\text { - Brat i sestra: brat je naljutio sestru, ona s njim dijeli } \\
\text { jabuku } \\
\text { - Sestre: nose marame, imaju slične igračke (auto i } \\
\text { trotinet), bude se rano zbog odlaska u školu }\end{array}$ \\
\hline
\end{tabular}




\begin{tabular}{|l|l|l|}
\hline 10. & OBITELJ & $\begin{array}{l}\text { - } \\
\text { - }\end{array}$ \\
& Otac, majka i sin: šeću parkom držeći se za ruke \\
& - Majka sa sinom i kćerkom: sjede zajedno na kauču; \\
& Majka sa sinom i kćerkom: djeca žele razonoditi i \\
& razveseliti majku-mole je da se s njima igra, smije \\
& i pjeva. \\
& Majka sa sinom i kćerkom: djeca se nadmeću tko \\
& će prvi pojesti nadjev od torte, majka ih nadmudruje \\
& dajući im zadatak da odu u podrum po drva, čime \\
& prekida njihovu igru nadmetanja \\
\hline
\end{tabular}

\subsubsection{Zaključne napomene}

Prizori iz obiteljskog života u bukvaru iz 1965. dosljedno se prikazuju kroz akcijske procese. Majčine kao akter sudjeluje u aktivnostima iz domena kuhanja, brige o djeci i domaćinstvu, pa joj je tako vektor uz ruku i kuhača, a ciljevi su shodno tome posuda sa hranom, prodavačica hrane na tržnici, dijete, rublje na konopcu za sušenje, šivaća mašina itd. Sredstva su naravno kuhača i torba za hranu. Često nosi radnu pregaču, jer obavlja kućanske poslove ili kuha. Otac je s druge strane samo jednom prisutan, vektori su mu ruke i kruh, a cilj je stol koji servira za objed, skupa sa ostalim članovima obitelji. On jedini upućuje direktni pogled čitaocu (zahtjev), kao glava obitelji, dok je kod ostalih članova prisutna samo ponuda. Djevojčica je poput majke vezana uz domenu kuhanja, ali i njege, pa su njezini ciljevi tanjur, bolesna baka i štednjak, dok joj ruke kao vektore potpomaže žlica i bočica sirupa (lijek). Ona izborom odjeće oponaša majku. Baka se također nalazi u istom području aktivnosti, pa su njezine ruke u ulozi vektora uposlene zrnima kukuruza ( $c i l j$ su kokoši) i pletećim iglama kojima plete čarapu ( $c i l j)$. Vizualno je istaknuta naočalima i sijedom kosom, što ukazuje na starost i slab vid. Djed kao akter za cilj ima šubaru, a same ruke su vektori. Njega vizualno određuju sijedi brkovi, kakve će imati dosljedno i u narednim bukvarima. Slika obitelji pripada svijetu čitaoca bukvara, budući da je prikazana iz prednjeg horizontalnog kuta i vertikalnog na razini oka. Svi članovi obitelji najčešće sudjeluju u nekoj vrsti materijalnih društvenih aktivnosti iz kojih ćemo izdvojiti razlike između onoga što rade dječak i djevojčica u obiteljskom okruženju. Dječak je 
okrenut igri, razonodi, jelu (zviždati, čuditi, gledati, jesti, nacrtati), dok je djevojčica i u jezičnom sadržaju posvećena njezi bolesnih i kuhanju (otići u apoteku, kupiti lijek, ispeći paprike). Majka je također u aktivnostima koje se svode na kućanske poslove (brisati, prostirati), kao i baka koja pak brine o domaćim životinjama (hraniti kokoši, nositi kukuruz). Kada je riječ o iskazivanju emocija, dječak grli i ljubi baku (materijalna prijalazna interaktivna), čestita majci rođendan i ljubi je, dok majka miluje kćer. Obuhvatit ćemo ovdje i načine nominacije ili identifikacije članova obitelji koji su istaknutiji, npr. majka sina zove mamino pile (posevizacija), dječak baku od milja zove bakice, ona je tjelesno identificirana sijedom kosom, a brat je za sestru junak unatoč tomu što je u tom trenutku beba u kolijevci. Međusobne obiteljske odnose u bilo kojoj formi i zastupljenosti imaju svi članovi obitelji osim oca i kćeri i djeda i unuke. Ovaj drugi će ostati izostavljen i kroz naredna tri bukvara. Sliku obitelji na okupu čine roditelji i dvoje djece, dječak i djevojčica.

Najoskudnije prikazana slika obiteljskog života je u bukvaru iz 1974. godine gdje imamo jedan akcijski proces, dva obiteljska portreta i konceptualnu reprezentaciju. U akcijskom procesu su majka i kćerka, koja je akter, a majka je cilj. Ranije je djevojčicu izbor odjeće vizualno približavao majci, ovdje je to boja kose na fotografiji zagrljaja majke i kćerke. Tu susrećemo i djelomično niski vertikalni kut, jer se čitalac stavlja u poziciju divljenja njihovoj ljubavi. Na ostalim prikazima je dosljedno prednji horizontalni i vertikalni na razini oka koji ne uspostavlja odnose moći između prikazanih aktera i čitaoca. Djed i unuk su također akteri sa zajedničkim ciljem - drvetom koje sade, kopajući zemlju lopatama (vektori i sredstva). Većina članova obitelji na portretima upućuje zahtjev čitaocu, ali je prisutna i ponuda kod koje izostaje direktni pogled. Majka u ovom bukvaru sudjeluje u manje kulinarskih aktivnosti, ali je i dalje vezana uz kućanske poslove i brigu o djeci (staviti cvijeće u vazu, kupiti sinu kaput materijalne prijelazne instrumentalne aktivnosti) Prisutne su emocije radosti (semiotičke prijelazne aktivnosti) i kod majke i kod sina. U zagonetci, kojoj je odgovor kćerka, djevojčica se određuje prema muškom rodu („Tatino dete, mamino dete, a ničiji sin.“). Kada je riječ o međusobnim obiteljskim odnosima u slikovnim i jezičnim sadržajima i ovdje izostaje interakcija između djeda i unuke, i oca i kćeri. Sliku obitelji na okupu čini proširena brojna obitelj sa starinskog portreta koji uključuje bližu i dalju rodbinu, kao i fijakeristu, što ne odgovara vremenu nastanka bukvara.

Bukvar iz 1996. postavlja obiteljske odnose na razinu kakvu ćemo u manje-više sličnoj formi susresti i posljednjem bukvaru iz korpusa. Članovi obitelji sudjeluju u akcijskim procesima, ali ih se nalazi u konceptualnim reprezentacijama, budući da analitički procesi 
karakteriziraju ovaj bukvar. Majka kao akter ostaje u domeni kućanskih poslova i pripreme hrane pa su njezini vektori uz ruke kuhača, pegla i košara sa hranom, a kao ponavljajući cilj javlja se kćerka. Majka je i pratnja, i to kćerki i suprugu. Kada se bavi kućanskim poslovima, ima maramu na glavi, a u drugim situacijama ima cvijet. Djevojčica također ostaje u domeni hrane i njege bolesnih (kao i u bukvaru iz 1965.) međutim ovdje ipak u ulozi Crvenkapice. Kao akter za cilj ima majku, natpis od cvijeća na kojem piše „mama“, knjigu, bakinu kuću, vuka. U obiteljskom kontekstu ona je pratnja majci. Dječak zadržava svoju ulogu lovca i avanturiste, pa su shodno tome njegovi ciljevi u akcijskom procesu automobil i riba, koju lovi ribičkim štapom, što mu je ujedno i vektor (uz ruku) ali i sredstvo. Brat i sestra su interakteri držeći se za ruke, gdje su jedno drugome cilj. Odnos oca i sina prikazan je kroz igru šaha, gdje je otac akter, a cilj šahovska figura i dječak. Svi akteri se prikazuju na dugačkoj udaljenosti, uvijek iz prednjeg horizonotalnog kuta i vertikalnog na razini oka. Interakciju direktnim pogledom sa čitaocem najčešće uspostavljaju upravo dječak i djevojčica, budući da su njegovi vršnjaci i obraćaju mu se kroz ovaj bukvar. Djed i ovdje zadržava svoje duge sijede brkove, ali dobiva štap kao pomoćno sredstvo za hodanje, što dodatno podvlači poznu životnu dob i teškoće sa kretanjem. Analiza jezičnih dijelova sadržaja pokazuje da se djevojčica u obiteljskom kontekstu tjelesno, ali i dobno klasificira pridjevom mala (mala Maša). Dječak se referira na roditelje koristeći prisvojnu zamjenicu moj (moj tata, moja mama). Djevojčice se rano ustaju (materijalna neprijelazna aktivnost), čim se ističe njihova discipliniranost i radišnost, a majka ostaje vezana uz kuhanje kroz glagol napraviti koji se odnosi na tortu. Kod semiotičke prijelazne aktivnosti treba istaknuti glagol voljeti, koji dječak usmjerava prema ocu, majci i sestri. Od ostalih primjera tu su misliti (majka misli na sina) i smiješiti se (majka sinu). Međusobni odnosi članova obitelji ovdje su pojačani postojanjem interakcije između oca i kćerke, koji odlaze na sajam knjiga. Ipak, treba naglasiti da ova situacija nije prikazana slikom, koja bi npr. bila akcijski proces, nego je riječ o tekstu koji se dopunjava slikama. Odnos djeda i unuke ponovno izostaje, a sliku obitelji na okupu ovdje čine roditelji sa djecom (sin i kćerka) uz djeda i baku na izletu. Isto tako, obitelj je i u tročlanoj formi i čine ju otac, majka i kćerka.

Članovi obitelji u bukvaru iz 2011. najčešće sudjeluju u akcijskim i reakcijskim procesima, a prisutni su i kao interakteri što dodatno ukazuje na bliskost koju jedni s drugima ostvaruju. Npr. interakteri su sin koji se drži za ruke sa oba roditelja, i majka sa sinom i kćeri između kojih sjedi i grli ih sa svake strane, ali i majka i kćerka u Crvenkapici. Kada je majka akter u akcijskom procesu i ovdje u ruci ima kuhaču ili košaru sa hranom (vektori i sredstva), a cilj joj je lonac, hrana, ćerka, sin, knjiga. Djevojčica je u domeni hrane i brige o starijima i nemoćnima samo kao Crvenkapica, pa su joj stoga ciljevi bakina kuća, košara sa hranom, vuk 
i jabuka. S druge strane, dječak je usmjeren prema potpuno drugačijim aktivnostima u obiteljskom okruženju, sredstava koja koristi su daljinski upravljač i olovka, a ciljevi su mu televizor, pismo i posuda sa nadjevom za tortu. Kada se obitelj daje na okupu, prikazuje se sa dugačke udaljenosti, ali uvijek iz prednjeg horizontalnog kuta i vertikalnog na razini oka. Zahtjev upućuje jedino djevojčica u ulozi Crvenkapice, koja baki nosi hranu i direktno gleda čitoaca. Po pitanju izgleda, treba podvući da prvi put u ovom bukvaru vidimo odraslu žensku osobu da nosi hlače, to je majka. Ranije smo vidjeli djevojčice u hlačama, ali zimi dok se pravi snjegović. Majka i baka također imaju kraću kosu nego što je to bilo u starijim bukvarima, čime se uklapaju u izgled svojih suvremenica. Djed zadržava bujne sijede brkove i štap, a na jednom crtežu podsjeća na Vuka Karadžića, čime je ostvarena veza sa tradicijom i pričanjem priča (djed unuku priča priče). Novine u jezičnoj analizi u ovom bukvaru, u odnosu na prethodni odnose se na primjere funkcionalizacije društvenih aktera, je ovdje susrećemo majku kao caricu, a njezinu kćer kao princezu, doduše ne u nekoj objektivnoj dječjoj stvarnosti, nego u snu koji sniva djevojčica. Princeza je tjelesno identificirana kao lijepa, a princ dobno kao mlad princ. Otac sudjeluje u materijalnim prijelaznim aktivnostima komunikacije i težih poslova (uzeti telefon, namontirati gumu). Majka neizostavno obavlja kućanske poslove i bavi se pripremom hrane (oprati sudove, napraviti tortu, razmaknuti zavjese itd.). Djevojčice se i ovdje odlikuju ranim buđenjem, npr. ustajati se - semiotička neprijelazna aktivnosti, dok kod prijelazne imamo emocije. Brat se ljuti na sestru, voli majku, oca i sestru i djevojčica se zaljubljuje u princa. Međusobne interakcije u slikovnim i jezičnim sadržajima ostvaruju svi članovi obitelji, osim unuke i djeda gdje dosljedno izostaje odnos. Otac kćerke i oca je pojačan time što ona nosi njegov sat (rečenica u tekstu koji dopunjavaju slike) i kao i u prethodnom bukvaru, odlaze na sajam knjiga. Obitelj kao cjelinu čine roditelji, kćerka i sin sa djedom i bakom na izletu, zatim roditelji i sin i majka sa sinom i kćeri sa kojima provodi slobodno vrijeme, daje zadatke i postavlja odgojne mjere prema njima. Iz ovoga možemo zaključiti da je majka centralna figura obitelji. 


\section{ZAKLJUČAK}

U ovome se poglavlju iznose najvažniji rezultati istraživanja, koji se potom dovode u vezu sa suvremenim društvenim kontekstom.

Etnicitet je u ovom radu analiziran kroz pojavu državnih simbola, povijesnih ličnosti i organizacija koje su sačinjavale državu, tj. ulazile u koncept domovine - poput pionira ili armije. U bukvarima iz 1965. i 1974. godine, dakle u vrijeme socijalističkog državnog uređenja, domovina se prikazuje kroz obnovu, izgradnju, ali i obranu. Završetak Drugog svjetskog rata zemlja je dočekala s velikim ljudskim gubicima i materijalno razorena, pa u duhu obnove i široko rasprostranjenih radnih akcija domovinu u bukvaru iz 1965. grade i oni najmlađi pioniri. U narednom bukvaru iz 1974. godine, a to je zapravo već trideset godina od završetka Drugog svjetskog rata, domovina se nastavlja braniti, čuvati i voljeti. Mirnodopska vremena nalažu i druga sredstva obrane, pa to više nije oružje nego knjige, pjesme, znanje, čast itd. Ipak, pojedinac je asimiliran u veće skupine poput pionira i armije. Tragom definicije JNA iz Vojne enciklopedije o Armiji kao ,zajedničkoj oružanoj sili svih naroda i narodnosti i svih radnih ljudi i građana SFRJ“, ne čudi inzistiranje na poistovjećivanju pojedinca s njom. Inicijacija pojedinca u armiju kreće preko svečanosti primanja u pionire, koja se održavala svake godine 29. studenog na Dan Republike. U bukvaru iz 1974. godine manifestacija je zaista prikazana kao svojevrsni obred prijelaza, i na najširem planu to jest bio svojevrsni ulazak u svijet odraslih. Pionirske kape prikazane su u zelenoj boji, umjesto plave, čime je naglašena veza s partizanima koji su oslobodili zemlju od neprijatelja. Armija u bukvaru funkcionira na dvije razine: (1) Titova armija, čiji je on tvorac i vrhovni zapovjednik i (2) armija koju čine djeca, a ta ista djeca polaganjem pionirske zakletve postaju pioniri. Tito je njihov nadređeni na obje razine. Kao predsjednik, u građanskom odijelu nadređen je učenicima koji ga dočekuju prvog dana škole na crno-bijeloj fotografiji u bukvaru iz 1965. godine, a nadređen im je i kao vrhovni zapovjednik jer se među pionirima pojavljuje u vojnoj odori. Društvene uloge usklađene su s izborom odjeće, ne samo ovdje u odnosima Tita i djece, nego i kod drugih aktera. Raspadom SFRJ početkom devedesetih godina prošlog stoljeća domovina se prestaje percipirati kroz državne simbole i obranu te se izjednačava s prirodom, u kranjem sa svime što čini život na planeti Zemlji. Ova promjena koncepta ne proizlazi iz nadrastanja državnih simbola, nego iz konfuzije koja je nastala postepenim razdruživanjem nekadašnjih republika koje su ulazile u 
sastav SFRJ. Srbija se prvo našla u sastavu Savezne Republike Jugoslavije, potom je činila dio Državne zajednice Srbija i Crna Gora, da bi na kraju postala samostalna republika. Iako se u bukvaru iz 1996. i 2011. godine ne ističu državni simboli, budi se nacionalna svijest i jača se nacionalni identitet kroz jezik i vjeru.

Titovu poziciju na početku bukvara preuzima reformator srpske ćirilice i sakupljač narodnog stvaralaštva Vuk Stefanović Karadžić, a javlja se i Sveti Sava, prvo kao učitelj u tekstu anegdote, a potom 2011. isti tekst ilustrira slika sveca sa freske manastira Mileševa. Vuk Karadžić uglavnom se prikazuje u poznoj životnoj dobi, sijedih brkova sa crvenim fesom na glavi. Katkada je njegov lik uokviren u ovalni okvir, poput starinskih obiteljskih fotografija. Sijedi brkovi ukazuju na životno iskustvo, a fes kao dio narodne nošnje gradi poveznicu s nacionalnim, ali i poslom kojim se bavio - sakupljanjem narodnog stvaralaštva. Vuk Karadžić u bukvaru je predstavljen kao autoritarna figura koja se do razine djeteta spušta kroz ovalni okvir, čime se sugerira da je on poput daljnjeg rođaka iz prošlosti. Nije slučajno ni što lik djeda u bukvaru iz 2011. godine s bujnim sijedim brkovima i prslukom koji krase motivi narodne nošnje podsjeća na Vuka Karadžića (slika 81). Unatoč tomu što je na crtežu Vuk Karadžić prikazan kako nadgleda pisanje prvih slova djevojčice i dječaka, što je njegov portret uokviren poput daljnjeg rođaka iz prošlosti i što djed podsjeća na njega, nikada se ne izjednačava s djetetom. On zadržava svojevrsnu distancu, traži poštovanje i uspostavlja autoritet. Sveti Sava također traži poštovanje i uspostavlja distancu. U bukvaru iz 1996. nije prikazan likom, ali već 2011. vidimo sliku sveca sa freske iz manastira Mileševa u kojem su se čuvale Savine mošti sve dok ih Turci ne spaljuju 1594. godine. Obojica nad korisnikom uspostavljaju nastavnički autoritet, tražeći od njega poštovanje. Tito s druge strane, gradacijski od predsjednika države kroz bukvar iz sedamdesetih postaje mali Joža, dječak spreman na razne nepodopštine kao i bilo koje drugo dijete. Tito je boreći se u ratu oslobodio zemlju od neprijatelja, u društvenoj hijerarhiji na najvišoj je poziciji, no istovremeno on pruža ljubav i traži je zauzvrat. Tito voli djecu i ona vole njega, on ih grli i stavlja ruke na njihove glave. Gesta polaganja ruke na glavu, unatoč tomu što ovdje pripada vremenu socijalizma, ima inicijacijsku ulogu ako je istumačimo kroz vizuru svojevrsne sakramentalne geste. Naime, polaganje ruke na glavu čini se u kršćanstvu kada svećenik dodjeljuje sakramente svetog reda, kod krštenja i pokore. Dodjeljivanje svetih sakramenata jest inicijacija, kao što je vidjeli smo i stupanje u pionire. Tito na slici s početka bukvara iz 1965. godine (slika 2) ruku na glavu stavlja dječaku koji je s lijeve strane, dok dječaku koji je desno i ima pionirsku maramu oko vrata obuhvaća samo rukom oko ramena, budući da njega nije potrebno inicirati. Tito je potpuno prožet s pojedincem i neodvojiv od njega već kroz glavnu misao: Mi smo Titovi - Tito je naš. To uzajamno pripadanje i 
prisutnost u životu pojedinca od opismenjavanja pa na dalje trajalo je desetljećima. Stoga i ne čudi masovna žalost koja nastupa njegovom smrću, a slikovito je opisana u predgovoru knjige „Tito“(Goldstein, 2015):

\begin{abstract}
Jugoslavija je tog trenutka zaustavila dah. Na prvenstvenoj utakmici Hajduk - Crvena zvezda u Splitu nogometaši su stali kao ukopani, spontano zaplakali, pali jedan drugome u zagrljaj, utakmica je prekinuta. Zaustavljena je i štafeta koja je kroz cijelu zemlju Titu nosila čestitke za 88. rođendan. Opustjele su ulice u gradovima, ljudi su žurili kućama izvjesiti crne zastave. Na ispraćaju lijesa pred zagrebačkim kolodvorom stotine tisuća ljudi u tišini su slušale oproštaj s kajkavskom pjesmom Fala, u Beogradu su ljudi čekali i po 15 sati kako bi u Narodnoj skupštini odali počast maršalu i predsjedniku.
\end{abstract}

Moto Mi smo Titovi - Tito je naš godinama se kao mantra ponavljao i Titovom smrću, nestao je i dio svakog pojedinca u kojeg je ova misao bila ugrađena.

Rodni i međugeneracijski odnosi u bukvarima od 1965. do 2011. odražavaju sliku tradicionalnog patrijarhalnog društva u kojem su jasno podijeljene uloge muškaraca i žena, posebno u obiteljskom okruženju. Unatoč zakonski ostvarenim pravima žena, emancipaciji u socijalističkom društvu, mogućnosti da radi, zarađuje i napreduje na društvenoj ljestvici, žena je u bukvaru i dalje vezana uz domenu domaćinstva i njege bolesnih. Bukvar iz 1965. godine ima posebnu naglašenu podjelu uloga: djevojčice su dobre učenice i vrijedne, najčešće drže cvijeće, ukrašavaju ili održavaju higijenu prostora, dok dječak lovi ili hrani razne vrste životinja, ima igračke koje traže dinamičnu igru poput lopte, papirnatog zmaja, rakete itd. Oni su vojskovođe, ribolovci, avanturisti, dok su djevojčice dobre učenice, vrijedne su, pomažu u kući i preuzimaju brigu o bolesnima. Desetak godina kasnije djevojčice ostaju u domeni domaćinstva, prvenstveno pripreme hrane, dok dječak zadržava svoju ulogu lovca. Devedesete donose više interakcije između oba spola, a podudara se i izbor ciljeva prema kojima su u akcijskim procesima usmjereni. Ona i dalje često ima cvijet, u kosi ili u ruci, a kada sudjeluje u istim aktivnostima sa dječakom, prati njegov ritam. Dok on pokreće i vodi igru, ona slijedi ili promatra. Njezina kosa i dalje je duga, a u bukvaru iz 1996. posebno je preuveličana, kao i cvijeće s kojim dolazi u doticaj. U bukvaru iz 2011. godine djevojčice su aktivnije u igrama koje dijele sa dječacima, ali ona ni tada ne napušta svoju ulogu njegovateljice ostavši vezana i uz domenu domaćinstva.

U kontekstu odnosa djevojčica i dječaka ovdje treba nešto više reći i o vršnjačkoj ljubavi, koja čini sastavni dio školovanja i odrastanja. U prethodnom poglavlju vidjeli smo da u situacijama u kojima dječak ili djevojčica pokazuje simpatiju za ono drugo, očekivana 
reakcija druge strane izostaje (npr. slika 65 i slika 66). Ipak, u bukvaru iz 2011. godine postoji jedna situacija uzajamne simpatije i pokazat ćemo je u ovome poglavlju jer s razlogom nije bila posebno analizirana ranije. Naime, situacija pripada domeni nerealnog, smještena je u san i slika 82 ilustracija je teksta pjesme Dobrice Erića Princeza. U pjesmi djevojčica sanja da se zaljubljuje u princa i princ u nju, ali majka je budi i vraća u realnost u kojoj treba pustiti stoku na pašu. Slika 82 pripada reakcijskom procesu u kojem je ostvarena uzajamnost. Naime, djevojčica u ulozi princeze je i reakter, ali istovremeno i fenomen, a isto je i sa dječakom u ulozi princa. Oni su jedno drugome fenomeni, budući da njihovi pogledi formiraju liniju vektora prema onome drugome. Prikazani su sa srednje udaljenosti, iz prednjeg horizontalnog kuta i vertikalnog na razini oka, što ih svrstava u svijet korisnika i izjednačava s njim. Izbor odjeće i bez oslanjanja na tekst pjesme daje informacije o ulogama princa i princeze - ona ima tijaru na glavi i haljinu koja se od struka naniže širi poput krinoline, a on je u odijelu ukrašenih revera, sa širokim pojasom oko pasa i u košulji ukrašenoj volanima. Pozadina je žute boje, ali bijeli obrisi otkrivaju konture dvorca, što naglašava njihove uloge. Analizirajući interakcije djevojčica i dječaka kroz sva četiri bukvara, prisjetimo se da 60-ih najviše vremena provode zajedno kada su pioniri, redari ili kada se igraju rata. Sedamdesete ne donose puno promjena, a sredinom 90-ih djevojčice se više igraju sa dječacima, da bismo u 2011. stigli i do vršnjačkih simpatija. Možemo reći da ljubav jeste ostvariva, ali u domeni sna i kroz društvene uloge koje stvarnost ne podražava - kada su princ i princeza.

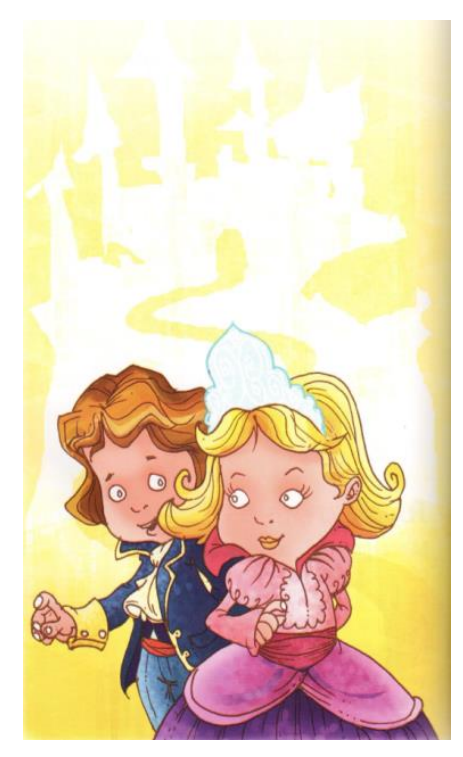

Slika 82 (Preuzeto iz Milatović, Ivković 2011.)

Ukoliko rodne odnose svedemo na karakteristike koje se ponavljaju iz bukvara u bukvar, vidimo da je ženski rod jako vezan uz zemlju preko cvijeća, ukrasnih grančica, 
ozlijeđenih životinja s kojima djevojčica dolazi u doticaj, hrane koju priprema majka ili baka, ili hranjenja životinja kojim se bavi baka. Muški rod, konkretno dječak ostaje lovac, osim kada u bukvaru iz 2011. godine odustane od lova i poželi se družiti sa životinjama (str. 105). Otac je figura koja također zadržava lovačke vještine, pa sa sinom odlazi u ribolov, ali ga uči i igrati šah, putuje s njim itd. Djed je izostavljen iz aktivnosti ove vrste, on daje mudrost, savjete i pripovijeda unuku priče, a od 90-ih naovamo se i likom i osobinama približava Vuku Karadžiću. Neraskidiva veza žene i zemlje može se tumačiti kao ostatak matrijarhata u društvu sa ustaljenim patrijarhalnim ulogama, budući da je upravo žena otkrila hranjivost biljaka.

Žena je, naime, bila ta koja je prva uzgojila prehrambene biljke; time je postala vlasnicom tla i žetve.

Magijsko-religiozni prestiž, pa prema tome, i društvena nadmoć žene ima kozmički model: figuru Zemlje-Majke. (Eliade 2002: 88)

U bukvarima je žena često svojim imenom izjednačena sa biljkama, tj. sa prirodom: Ljiljana, Đurđa (od Đurđica), Ljubica, Biljana. Prisjetimo se i hiperbolizirane kose u bukvaru iz 1996. i uopće naglašeno dugačke kose kod svih aktera ženskog spola. Kosa poprima oblik suvremene frizure tek u bukvaru iz 2011. godine, kada se i djevojčica i majka i baka pojavljuju sa skraćenom kosom. Prateći gore spomenutu magijsko-religioznu dimenziju i tragajući za značenjem kose u tradicionalnim kulturama (simbol snage, bogatstva, izobilja, sreće, ali je i tabuirana, magijski moćna, čini vezu sa onostranim) proučavaoci narodne književnosti ističu promjenu načina češljanja kao dio obreda prijelaza i važnost pokrivanja glave, što smo vidjeli u bukvaru iz 1965. na baki:

\footnotetext{
Javno skidanje marame sa ženske glave (pogotovo kada je reč o majci) značilo je kod svih balkanskih naroda suštinski poremećaj svakodnevnog socijalnog poretka i nagoveštavalo ili smrt, ili kletvu (žene su klele gologlave), ili ropsko preklinjanje i apsolutno pokoravanje - deo obreda kojim se mirila krv bio je i dolazak gologlavih žena sa kolevkama da bi molile da se osveta zameni kumstvom. U većini tradicionalnih kultura, sem toga, po načinu češljanja i dužini kose razlikuju se različiti uzrasni i socijalni statusi. Promena načina češljanja i pokrivala za glavu bila je sastavni deo obreda prelaza. I seoske i urbane kulture su, maltene do našeg doba, jasno razlikovale frizuru primerenu devojčici, devojci i udatoj ženi. (Pešikan Ljuštanović 2016:96)
}

Dokaz za percepciju žene kao bića povišene moći, koja čini most između ljudske zajednice i prirode, nalazi se u brojnim metaforama i usporedbama koje u narodnom stvaralaštvu ženu dovode u vezu sa vodom, posebno sa plodotvornom rosom (Pešikan Ljuštanović 2016:99). Povjesničar religija i antoropolog Mircea Eliade kaže da je žena na mističan način solidarizirana sa zemljom: 
Rađanje je ljudska varijanta telurističke plodnosti. Sva religiozna iskustva koja su u vezi s plodnošću i rođenjem imaju kozmičku strukturu. Sakralnost žene dolazi od svetosti Zemlje. Ženska plodnost ima kozmički model: plodnost Terra Mater, univerzalne Roditeljice (Eliade 2002:88).

Na kraju, možemo zaključiti da se društveno-političke promjene poput drugog državnog uređenja, u bukvarima reflektiraju kao vidljive i brze izmjene sadržaja koji se prvenstveno odnose na simbole državnosti, a povijesne osobe smjenjuju se u svojim ulogama preuzimajući pozicije svojih prethodnika. Najveći dio istraživanja ovog rada bio je posvećen rodnim odnosima, koji su i najsporije odražavali društvene promjene. U zaključnom promišljanju možemo reći da su rodni odnosi u svojoj suštini svedeni na ženu neodvojivu od zemlje i na muškarca-lovca. Neki budući istraživači bi ovim rezultatima mogli pristupati kao proučavanju kolektivnog nesvjesnog, arhetipovima i sl., a neki budući autori novih bukvara će, nadajmo se, djevojčici dati aktivnije uloge i između nje i dječaka jednom umetnuti ljubav kao ostvarivu i uzvraćenu emociju. 


\section{Popis literature}

Bogdanović, D., 1986: Sveti Sava Sabrani spisi, Prosveta Srpska književna zadruga, Beograd.

Božinović, N., 1996: Žensko pitanje u Srbiji u XIX i XX veku, Beograd.

Čalić Mari-Žanin, 2013: Istorija Jugoslavije u 20. veku, Clio. Beograd.

Čigoja, B., 2010: Kratak pregled prvih srpskih bukvara, Bukvari i bukvarska nastava, Zbornik radova, Pedagoški muzej, Beograd.

Ćunković, S., 2010: Bukvari i bukvarska nastava, Zbornik radova, Katalog izložbe Bukvari i bukvarska nastava kod Srba, urednik Borivoje Aksentijević, Pedagoški muzej, Beograd.

Deretić, J., 1983: Istorija srpske književnosti, Nolit, Beograd.

Deretić, J., 1991: Historija književnosti za I razred srednje škole. Šesto izdanje, Zavod za udžbenike i nastavna sredstva Beograd, Zavod za izdavanje udžbenika Novi Sad.

Duda, I., 2015: Danas kada postajem pionir, djetinjstvo i ideologija jugoslavenskoga socijalizma, Srednja Europa, Sveučilište Jurja Dobrile. Zagreb - Pula.

Eliade Mircea, Sveto i profano, AGM 2002, Zagreb

Enciklopedija Jugoslavije 2, Bosna-Dio, 1956: Leksikografski zavod FNRJ, Grafički zavod Hrvatske, Zagreb

Goldstein I.,Goldstein S., 2015. Tito, Profil, Zagreb

Gudac - Dodić,V., 2006: Položaj žene u Srbiji (1945-2000). Žene i deca. 4. Srbija u modernizacijskim procesima IXI i XX veka. Br.23 Biblioteka Helsinške sveske, Beograd.

Halliday, Michael A.K.,1978: Language as Social Semiotics: the social interpretation of language and meaning, London, Edward Arnold.

Halliday, Michael A. K., 1985: An Introduction to Functional Grammar, prvo izdanje, London, Edward Arnold.

Halliday, Michael A. K.,1994: An Introduction to Functional Grammar, drugo izdanje, London, Edward Arnold.

Halliday, Michael A. K., Christian M. I. M. Matthiessen, 2004: An Introduction to Functional Grammar, treće izdanje, London, Edward Arnold. 
Hrvatsko antropološko nazivlje, Terminološki rječnici Strune, knjiga br. 3,: 2015: Institut za hrvatski jezik i jezikoslovlje, Zagreb

Ivić, P., 1998: Pregled istorije srpskog jezika. Izdavačka knjižarnica Zorana Stojanovića Sremski Karlovci Novi Sad.

Karadžić, V., 1827: Prvi Srpski bukvar, Štamparija Jermenskog manastira, Beč.

Kress, G. i Van Leeuwen Th. 2006: Reading Images, The Grammar of Visual Desing. Taylor and Francis e-Library.

Mano-Zisi, K. 2010: Prvi štampani srpski bukvar iz 1597. godine, Bukvari i bukvarska nastava, Zbornik radova, Pedagoški muzej, Beograd.

Matković, H., 1998: Povijest Jugoslavije (1918-1991). Naklada Pavičić, Zagreb.

Matošević, A., 2016: Više od zbroja infrastrukturnih postignuća: omladinske radne akcije i fenomenologija moralne ekonomije dara, Narodna umjetnost 2/56.

Milanović, A., 2010: Kratka historija srpskog književnog jezika, Zavod za udžbenike. Beograd.

Mrkalj, Z., 2010: Osvrt na bukvarsku produkciju u Srbiji u periodu od 2003. do 2009. godine. Bukvari i bukvarska nastava, Zbornik radova, Pedagoški muzej, Beograd.

Okuka, M., 2010: Salo debeloga jera libo azbukoprotres Save Mrkalja u starom i novom ruhu. SKD Prosvjeta, Zagreb.

Petranović, B., 1988: Historija Jugoslavije (1918-1988).Treća knjiga, Nolit, Beograd.

Pešikan Ljuštanović Ljiljana, Žensko telo kao prostor u usmenoj obrednoj lirici, Sarajevske Sveske br. 49-50, 2016. http://sveske.ba/en/broj/49-50-0

Stojanović, D., 2010: Ulje na vodi. Ogledi iz istorije sadašnjosti Srbije, Peščanik, Čigoja Štampa, Beograd.

Van Leeuwen, Th. 2005: Introducing Social Semiotics. Taylor and Francis e-Library.

Van Leeuwen, Th., 2008: Discourse and Practice, New Tools for Critical Discourse Analysis, Oxford University Press.

Vojna enciklopedija, 4 dio Jakac-Lafet, drugo izdanje, 1972: Vojnoizdavački zavod, Beograd 
Izvori

http://www.stat.gov.rs/

$\underline{\text { www.sabor.hr }}$

http://www.arhivyu.gov.rs/active/srlatin/home/glavna_navigacija/leksikon_jugoslavije/drzavn i_simboli/zastava.html) 


\section{ŽIVOTOPIS}

Nataša Puškar rođena je 1978. godine u Sisku. Diplomirala je na Filozofskom fakultetu u Novom Sadu 2002. godine, na Katedri za srpski jezik i lingvistiku stekavši zvanje profesora srpskog jezika i književnosti. Za vrijeme studija počinje raditi na novosadskoj lokalnoj radio stanici In radio u svojstvu autorice i voditeljice programa do 2003. godine. Od 2003. do 2006. godine radi kao novinarka, urednica i autorica programa na Radiju 021 i u TV produkciji 021. Od ožujka 2006. zaposlena je u Vijeću srpske nacionalne manjine Grada Zagreba kao izvršna tajnica Vijeća.

Objavljeni radovi:

O žargonu i žargonskim metaforama za ženu i muškarca u srpskom i hrvatskom jeziku, Slavenski jezici u usporedbi s hrvatskim III. Sesar, Dubravka (ur.). Zagreb: FF press, Filozofski fakultet, 2013. str. 121-129

Rodni odnosi u srpskom bukvaru iz 1965. godine, Što sanjamo, Knjiga radova povodom 70. rođendana profesora Dušana Marinkovića, Bogutovac D., Karlić V., Šakić S. (ur.), Zagreb: FF press, Filozofski fakultet i VSNM ZG, 2019. str. 244-250 